Prepared in cooperation with the McHenry County, Illinois

\title{
Hydrogeology and Water Quality of Sand and Gravel Aquifers in McHenry County, Illinois, 2009-14, and Comparison to Conditions in 1979
}

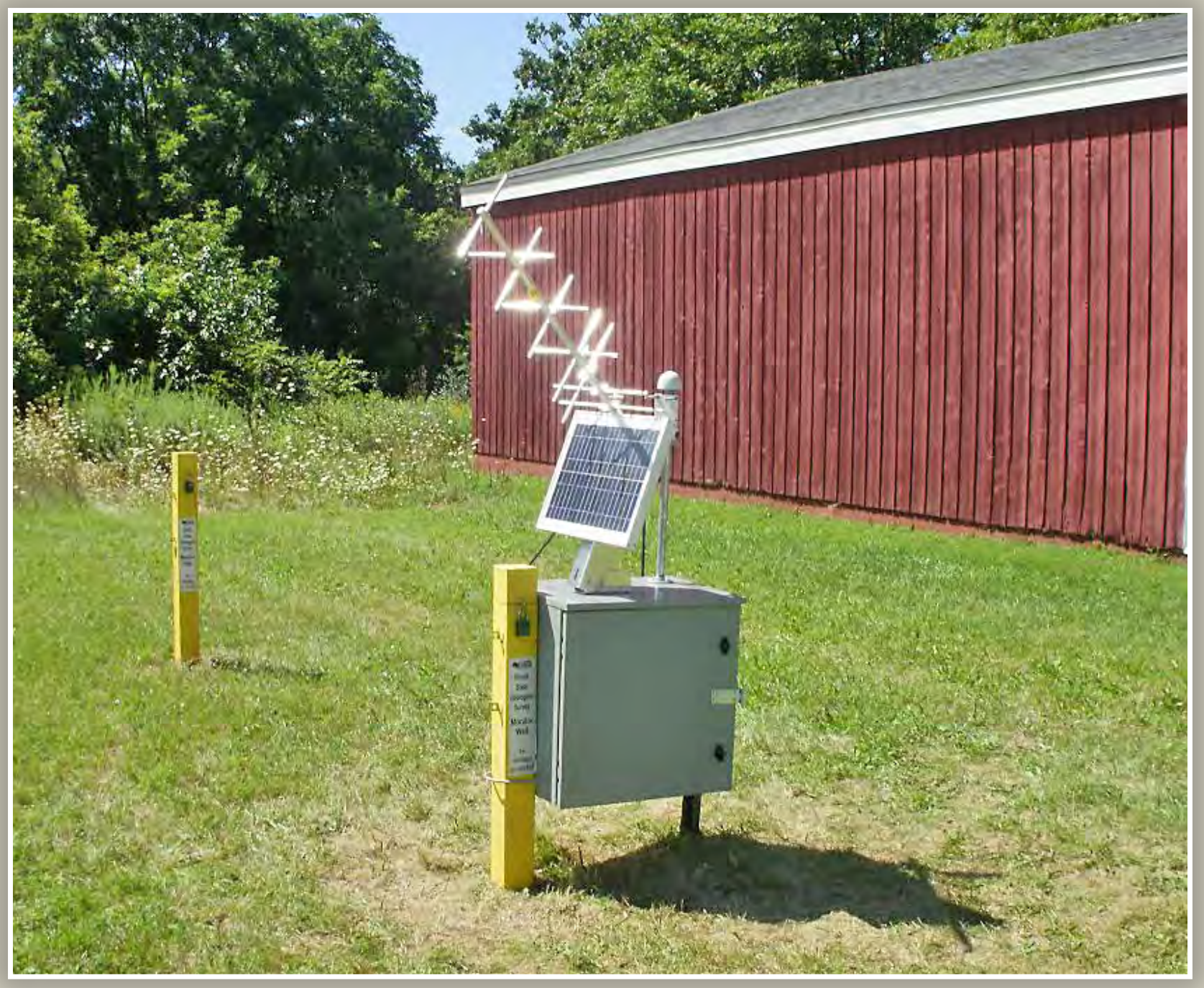

Scientific Investigations Report 2017-5112

Version 1.1, August 2022 
Cover: A real-time groundwater monitoring well in McHenry County, Illinois. Photograph taken by Mike Lee, U.S. Geological Survey, 2009. 


\section{Hydrogeology and Water Quality of Sand and Gravel Aquifers in McHenry County, Illinois, 2009-14, and Comparison to Conditions in 1979}

By Amy M. Gahala

Prepared in cooperation with McHenry County, Illinois

Scientific Investigations Report 2017-5112

Version 1.1, August 2022 


\title{
U.S. Department of the Interior \\ RYAN K. ZINKE, Secretary
}

\section{U.S. Geological Survey William H. Werkheiser, Acting Director}

\author{
U.S. Geological Survey, Reston, Virginia: 2017 \\ First release: 2017 \\ Revised: August 2022 (ver. 1.1)
}

\begin{abstract}
For more information on the USGS - the Federal source for science about the Earth, its natural and living resources, natural hazards, and the environment-visit https://www.usgs.gov or call 1-888-ASK-USGS.

For an overview of USGS information products, including maps, imagery, and publications, visit https://store.usgs.gov.
\end{abstract}

\author{
Any use of trade, firm, or product names is for descriptive purposes only and does not imply endorsement by the \\ U.S. Government. \\ Although this information product, for the most part, is in the public domain, it also may contain copyrighted materials \\ as noted in the text. Permission to reproduce copyrighted items must be secured from the copyright owner. \\ Suggested citation: \\ Gahala, A.M., 2017, Hydrogeology and water quality of sand and gravel aquifers in McHenry County, Illinois, \\ 2009-14, and comparison to conditions in 1979 (ver. 1.1, August 2022): U.S. Geological Survey Scientific \\ Investigations Report 2017-5112, 91 p., https://doi.org/10.3133/sir20175112. \\ ISSN 2328-0328 (online)
}




\section{Contents}

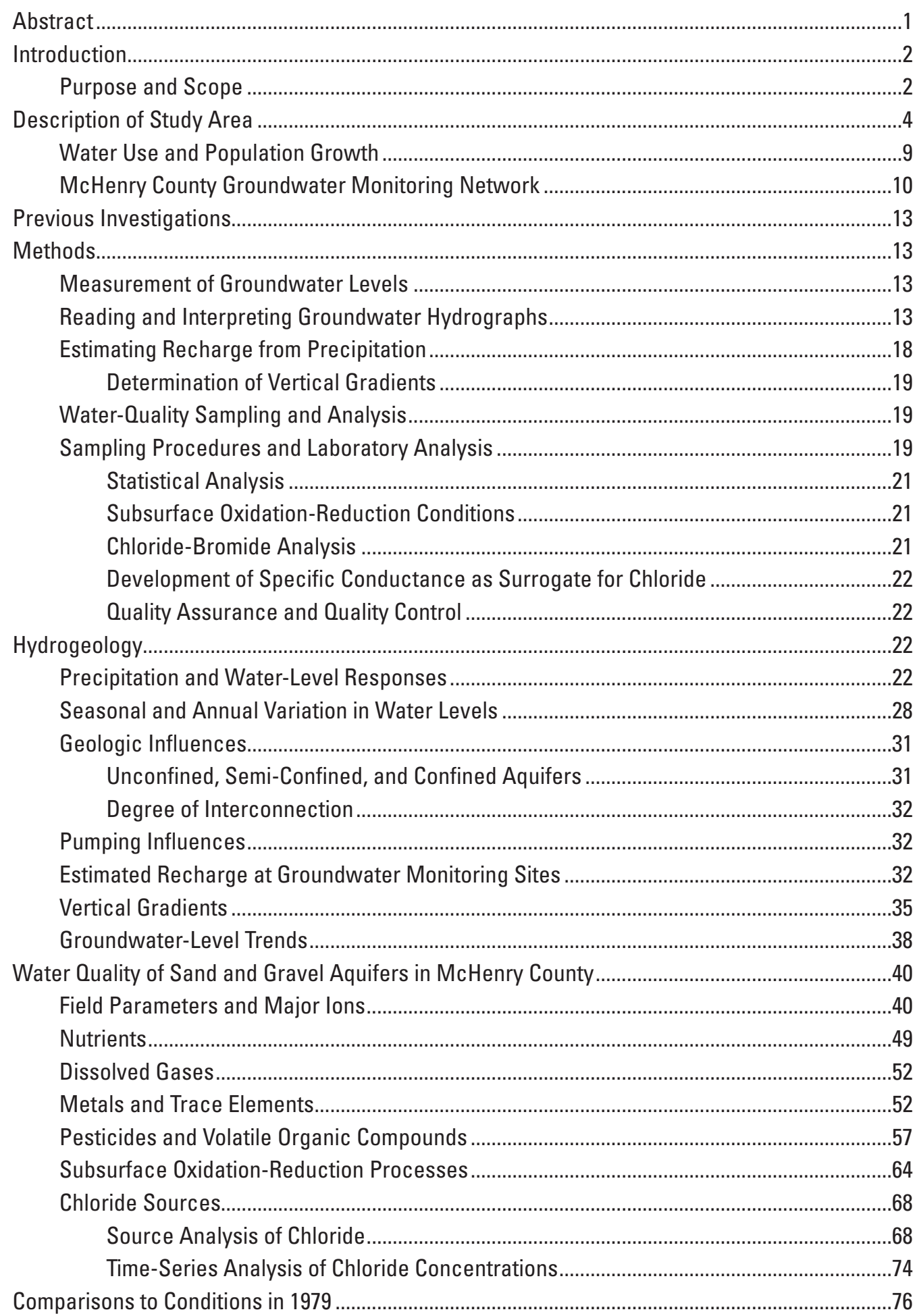




\section{Contents-Continued}

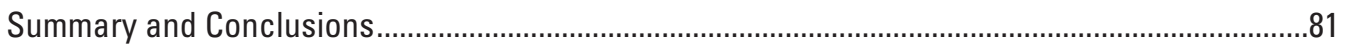

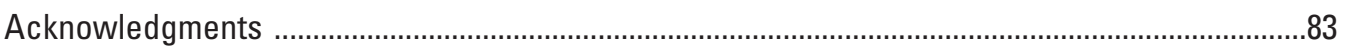

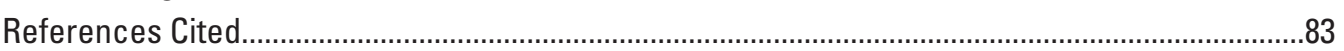

Appendix A. Well Log Lithology of National Water-Quality Assessment

Monitoring Well 44N9E-20.7c ………………………………..............................................91

\section{Figures}

1. Map showing groundwater monitoring wells, streamgages, and rain gages in McHenry County, Illinois.. .3

2. Map showing locations of center-pivot irrigation wells in McHenry County, Illinois .......5

3. Map showing major waterways, moraines, and land surface elevations in McHenry County, Illinois .

4. Conceptual drawing of alternating sand and gravel deposits and till deposits under the three general hydrogeologic settings commonly found in the subsurface of McHenry County, Illinois.

5. Map showing flow directions and water levels of shallow wells in the McHenry County groundwater monitoring well network, McHenry County, Illinois

6. Graph showing population growth and total water use in McHenry County, Illinois, 1985-2010

7. Photograph showing real-time groundwater monitoring well in McHenry County, Illinois

8. Hydrographs showing examples of rapid, moderate, and muted responses to precipitation in selected wells in the McHenry County groundwater monitoring network, Illinois

9. Graph showing example of inverse water-level responses to barometric pressure at monitoring well 4-RCH-D in McHenry County, Illinois.

10. Hydrographs showing examples of selected nested monitoring wells for strongly interconnected, moderately interconnected, and weakly interconnected aquifer units in McHenry County groundwater monitoring network, Illinois

11. Graph showing pumping influences during a period of drawdown and recovery in response to withdrawal of groundwater followed by the cessation of pumping at monitoring well 16-GRF-I, McHenry County, Illinois

12. Map showing monitoring wells with rapid, moderate, or muted water-level responses to precipitation in the McHenry County groundwater monitoring network, Illinois

13. Hydrographs showing water-levels in deep monitoring wells with rapid, moderate, or muted responses to precipitation in the McHenry County groundwater monitoring network, Illinois.

14. Map showing degree of aquifer confinementas determined from water levels and geology reported in well logs for the McHenry County groundwater monitoring network, Illinois

15. Map showing monitoring wells with and without pumping influences in the McHenry County groundwater monitoring network, Illinois 


\section{Figures-Continued}

16. Map showing estimated average recharge at selected unconfined and semi-confined wells in McHenry County, Illinois. Two wells were not included in the recharge estimates because of pumping influences...

17. Map showing aquifer sensitivity and vertical gradients at wells in the McHenry County groundwater monitoring network, Illinois.

18. Map showing water-level trends for the period of record for wells in the McHenry County groundwater monitoring network, Illinois, 2009-14...

19. Graph showing flow reversals as water levels in the intermediate well declined below the water levels of the deep well, McHenry County, Illinois, 2009-13.

20. Graph showing well depth and specific conductance in wells from the McHenry County groundwater monitoring network, Illinois, 2010

21. Graph showing relation of calcium and magnesium concentrations to well depth in water-quality samples collected from wells in the McHenry County groundwater monitoring network, Illinois, 2010

22. Graph showing distribution of major ions in water-quality samples collected from wells in the McHenry County groundwater monitoring network, Illinois, 2010.

23. Graphs showing chloride concentrations compared with impervious areas and well depth from wells in the McHenry County groundwater monitoring network, Illinois, 2010.

24. Graph showing chloride concentrations from periodic water-quality samples collected from selected wells in the McHenry County groundwater monitoring network, Illinois, 2009-15, and U.S. Environmental Protection Agency aquatic toxicity level.

25. Graphs showing relations of nitrate concentrations to dissolved-oxygen concentrations and well depth in water-quality samples collected from wells in the McHenry County groundwater monitoring network, Illinois, 2010

26. Graph showing ammonia concentrations and well depths from water-quality samples collected from wells in the McHenry County groundwater monitoring network, Illinois, 2010.

27. Map showing arsenic concentrations greater than the U.S. Environmental Protection Agency Maximum Contaminant Level of 10 micrograms per liter from selected wells in the McHenry County groundwater monitoring network, Illinois, 2010

28. Graph showing total iron and dissolved-oxygen concentrations in McHenry County groundwater monitoring network, Illinois, 2010 .

29. Boxplots showing distribution between arsenic, manganese, and iron for oxidation-reduction conditions of oxic, suboxic, mixed, and anoxic in water-quality samples collected from wells in the McHenry County groundwater monitoring network, Illinois, 2010.

30. Map showing oxidation-reduction conditions in wells in the McHenry County groundwater monitoring network, Illinois

31. Binary mixing curves for various chloride-to-bromide ratio sources and individual well chloride-to-bromide ratios represented by McHenry County groundwater monitoring network and National Water-Quality Assessment wells, McHenry County, Illinois, 2000-15.

32. Binary mixing curves for various chloride-to-bromide ratios sources in aquifer units represented by the McHenry County groundwater monitoring network and National Water-Quality Assessment wells, McHenry County, Illinois, 2000-15. 


\section{Figures-Continued}

33. Binary mixing curves for chloride-to-bromide ratios for urban and agriculture land cover represented by the McHenry County groundwater monitoring network and National Water-Quality Assessment wells, McHenry County, Illinois, 2000-15.......73

34. Graphs showing linear regressions and equations for chloride-specific conductance surrogate at selected wells in the McHenry County groundwater monitoring network, Illinois, 2011-14

35. Graphs showing estimated chloride concentrations from continuous specific-conductance and water-level elevation data for selected wells in the McHenry County groundwater monitoring network, Illinois, 2011-14.

36. Potentiometric surface maps showing Residential supply wells from the 1979 dataset, and deep aquifer units represented by corresponding McHenry County groundwater monitoring network, Illinois, May 2014

37. Map showing residential wells sampled in the McHenry County groundwater monitoring network, Illinois, 1979 and 2010.

38. Graph showing chloride concentrations and well depths of the 1979 residential wells and the $\mathbf{2 0 1 0}$ monitoring wells in the McHenry County groundwater monitoring network, Illinois.

\section{Tables}

1. Land-cover type, acreage, and percentage of change in McHenry County, Illinois, 2001-11

2. Water withdrawals and populations served, McHenry County, Illinois, 1985 and 2010 .

3. Construction of selected monitoring wells with water-level and water-quality data, and the identified aquifer unit, McHenry County, Illinois.

4. Monitoring wells and percentage of agricultural and urban lands within a 1,640-foot radial buffer zone around each well in the McHenry County groundwater monitoring network, Illinois

5. Decision matrix to determine degree of confinement from geology, water levels, and implications for water quality, McHenry County groundwater monitoring network, Illinois, 2009-14

6. Estimates of specific yield as described from lithologic descriptions for selected monitoring wells included in the water table fluctuation analysis for the calculation of recharge in McHenry County, Illinois

7. Field parameters, major and minor ions, metals, and nutrients analyzed for wells in McHenry County groundwater monitoring network, Illinois, 2010

8. Degree of aquifer confinement and interconnections from the analysis of water levels, responses to precipitation, barometric pressure, thickness of overlying clay, pumping influences, vertical gradient, and trends for wells in the McHenry County groundwater monitoring well network, Illinois

9. Highest and lowest annual water levels by season for wells in the McHenry County groundwater monitoring network, Illinois, 2009-14.

10. Precipitation and median water levels recorded in selected wells in the McHenry County groundwater monitoring network, Illinois, 2009-14. 


\section{Tables-Continued}

11. Peak water levels recorded in selected wells in the McHenry County groundwater monitoring network, Illinois, 2009.

12. Maximum drawdown during the 2012 drought conditions and 2010 normal precipitation conditions measured in wells in the McHenry County groundwater monitoring network, Illinois..

13. Recharge and annual average recharge estimated using the water-table fluctuation method for selected monitoring wells in the McHenry County groundwater monitoring network, Illinois, 2011-14.

14. Health- and aesthetically based benchmarks in water-quality samples collected from 46 monitoring wells in 2010, and periodic water-quality samples collected during 2011-15 in the McHenry County groundwater monitoring network, Illinois

15. Well sampling details and field parameters for wells in the McHenry County groundwater monitoring network, Illinois, 2010

16. Major and minor ions from wells in the McHenry County groundwater monitoring network and four wells from the National Water-Quality Assessment program, McHenry County, Illinois, 2010

17. Nutrients from water-quality samples collected from wells in the McHenry County groundwater monitoring network and four wells from the National Water-Quality Assessment program, McHenry County, Illinois, 2010.

18. Dissolved gases from selected monitoring wells in comprehensive water-quality sampling in McHenry County, Illinois, 2010

19. Metals from comprehensive water-quality samples collected from wells in the McHenry County groundwater monitoring network, Illinois, 2010.

20. Trace elements at selected monitoring wells in McHenry County, Illinois.

21. Pesticide and herbicide results from water-quality samples collected from selected monitoring wells in the McHenry County groundwater monitoring network, Illinois.

22. Volatile organic compound water-quality samples collected from selected wells in the McHenry County groundwater monitoring network, Illinois, 2010.

23. Oxidation-reduction categories and processes indicated by water-quality samples collected from wells in the McHenry County groundwater monitoring network, Illinois, 2010.

24. Specific conductance and chloride concentrations for periodic water-quality samples from selected monitoring wells in McHenry County, Illinois, 2009-14.

25. Chloride and bromide concentrations for periodic water-quality samples from five National Water-Quality Assessment program wells in McHenry County, Illinois, 2000-10

26. Saturated thickness of aquifer and horizontal hydraulic conductivity measured for selected wells in the McHenry County groundwater monitoring network, Illinois .........76

27. Median water-quality data from wells in the McHenry County groundwater monitoring network, Illinois, 1979 and 2010

28. Chloride concentrations in water-quality samples collected from resampled and sampled residential wells, McHenry County, Illinois, 1979 and 2015, respectively. 


\section{Conversion Factors}

Inch-Pound to International System of Units

\begin{tabular}{|c|c|c|}
\hline Multiply & By & To obtain \\
\hline \multicolumn{3}{|c|}{ Length } \\
\hline inch (in.) & 25.4 & millimeter (mm) \\
\hline foot $(\mathrm{ft})$ & 0.3048 & meter $(\mathrm{m})$ \\
\hline mile (mi) & 1.609 & kilometer (km) \\
\hline \multicolumn{3}{|c|}{ Area } \\
\hline acre & 0.004047 & square kilometer $\left(\mathrm{km}^{2}\right)$ \\
\hline square mile $\left(\mathrm{mi}^{2}\right)$ & 2.590 & square kilometer $\left(\mathrm{km}^{2}\right)$ \\
\hline \multicolumn{3}{|c|}{ Flow rate } \\
\hline gallon per minute (gal/min) & 0.06309 & liter per second $(\mathrm{L} / \mathrm{s})$ \\
\hline million gallons per day (Mgal/d) & 3,785 & cubic meter per day $\left(\mathrm{m}^{3} / \mathrm{d}\right)$ \\
\hline inch per year (in/yr) & 25.4 & millimeter per year (mm/yr) \\
\hline $\begin{array}{l}\text { gallon per day per square mile } \\
\qquad\left[(\mathrm{gal} / \mathrm{d}) / \mathrm{mi}^{2}\right]\end{array}$ & 0.00146 & $\begin{array}{l}\text { cubic meter per day per square } \\
\text { kilometer }\left[\left(\mathrm{m}^{3} / \mathrm{d}\right) / \mathrm{km}^{2}\right]\end{array}$ \\
\hline \multicolumn{3}{|c|}{ Hydraulic conductivity } \\
\hline foot per day (ft/d) & 0.3048 & meter per day $(\mathrm{m} / \mathrm{d})$ \\
\hline
\end{tabular}

International System of Units to Inch-Pound

\begin{tabular}{llll}
\hline \multicolumn{1}{c}{ Multiply } & \multicolumn{1}{c}{ By } & \multicolumn{1}{c}{ To obtain } \\
\hline & Length & \\
\hline millimeter $(\mathrm{mm})$ & 0.03937 & inch (in.) \\
meter $(\mathrm{m})$ & 3.281 & foot $(\mathrm{ft})$ & \\
\hline
\end{tabular}

Temperature is given in degrees Fahrenheit $\left({ }^{\circ} \mathrm{F}\right)$, which may be converted to Celsius $\left({ }^{\circ} \mathrm{C}\right)$ degrees as follows:

$$
{ }^{\circ} \mathrm{C}=\left({ }^{\circ} \mathrm{F}-32\right) / 1.8
$$

\section{Datums}

Except as otherwise noted, vertical coordinate information is referenced to the North American Vertical Datum of 1988 (NAVD 88).

Horizontal coordinate information is referenced to the North American Datum of 1983 (NAD 83).

Elevation refers to distance above or below the vertical datum. 


\section{Supplemental Information}

Abbreviated water-quality units used in this report: Sample-bottle volumes, and water temperatures are given in metric units. Micrograms per liter are considered equivalent to parts per billion at the reported concentrations. Bottle volumes are given in milliliter $(\mathrm{mL})$ or liter (L).

Specific conductance is given in microsiemens per centimeter at 25 degrees Celsius $(\mu \mathrm{S} / \mathrm{cm}$ at $\left.25^{\circ} \mathrm{C}\right)$.

Concentrations of chemical constituents in water are given in either milligrams per liter (mg/L) or micrograms per liter $(\mu \mathrm{g} / \mathrm{L})$.

Abbreviated water-use unit: Rate of water use generally is given in million gallons per day (Mgal/d), which may be converted to an equivalent flow rate given in cubic feet per second $\left(\mathrm{ft}^{3} / \mathrm{s}\right)$, as follows: $\mathrm{ft}^{3} / \mathrm{s}=\mathrm{Mgal} / \mathrm{d} \times 0.0438$.

\section{Abbreviations}

$\begin{array}{ll}\mathrm{CaCO}_{3} & \text { calcium carbonate } \\ \mathrm{CI} & \text { chloride } \\ \mathrm{CI}-\mathrm{Br} & \text { chloride-bromide } \\ \text { DO } & \text { dissolved oxygen } \\ \text { E } & \text { estimated } \\ \text { DWA } & \text { Drinking Water Advisory } \\ \text { DWEL } & \text { Drinking Water Equivalent Level } \\ \text { EPA } & \text { U.S. Environmental Protection Agency } \\ \text { GRMP } & \text { Groundwater Resource Management Plan } \\ \text { HA } & \text { Health Advisory } \\ \text { H S } & \text { Hydrogen sulfide } \\ \text { ISGS } & \text { Illinois State Geological Survey } \\ \text { ISWS } & \text { Illinois State Water Survey } \\ \text { MCGMN } & \text { McHenry County groundwater monitoring network } \\ \text { MCL } & \text { Maximum Contaminant Level } \\ \text { MRL } & \text { Minimum reporting level } \\ \text { NaCl } & \text { sodium chloride } \\ \text { NAWQA } & \text { National Water-Quality Assessment } \\ \text { NLCD } & \text { National Land Cover Dataset } \\ \text { NTU } & \text { Nephelometric turbidity unit } \\ \text { NWIS } & \text { National Water Information System } \\ \text { SMCL } & \text { Secondary Maximum Contaminant Level } \\ \text { TCE } & \text { Trichloroethene } \\ \text { TEAP } & \text { terminal electron-accepting processes } \\ \text { TDS } & \text { total dissolved solids } \\ \text { USGS } & \text { U.S. Geological Survey } \\ \text { VOC } & \text { volatile organic compound } \\ \text { WT fluctuation } & \text { Water-table fluctuation }\end{array}$





\title{
Hydrogeology and Water Quality of Sand and Gravel Aquifers in McHenry County, Illinois, 2009-2014, and Comparison to Conditions in 1979
}

\author{
By Amy M. Gahala
}

\section{Abstract}

Baseline conditions for the sand and gravel aquifers (groundwater) in McHenry County, Illinois, were assessed using data from a countywide network of 44 monitoring wells collecting continuous water-level data from 2009-14. In 2010, water-quality data were collected from 41 of the monitoring wells, along with five additional monitoring wells available from the U.S. Geological Survey National Water Quality Assessment Program. Periodic water-quality data were collected from 2010-14 from selected monitoring wells. The continuous water-level data were used to identify the natural and anthropogenic factors that influenced the water levels at each well. The water-level responses to natural influences such as precipitation, seasonal and annual variations, barometric pressure, and geology, and to anthropogenic influences such as pumping were used to determine (1) likely hydrogeologic setting (degree of aquifer confinement and interconnections) that, in part, are related to lithostratigraphy; and (2) areas of recharge and discharge related to vertical flow directions. Water-level trends generally were determined from the 6 years of data collection (2009-14) to infer effects of weather variability (drought) on recharge.

Precipitation adds an estimated 2.4 inches per year of recharge to the aquifer. Some of this recharge is subsequently discharged to streams and some is discharged to supply wells. A few areas in the eastern half of the county had higher average recharge rates, indicating a need for adequate protection of these recharge areas. Downward vertical flow gradients in upland areas indicate that recharge to the confined aquifer units occurs near upland areas. Upward vertical flow gradients in lowland areas indicate discharge at locations of surface water and groundwater interaction (wetlands, ponds, and streams).

Monitoring wells were sampled for major and minor ions, metals, and nutrients and a subset of wells was sampled for trace elements, dissolved gases, pesticides, and volatile organic compounds. The results were compared to health-based and aesthetically based standards, which include the U.S. Environmental Protection Agency Maximum Contaminant Level (EPA MCL), and EPA Secondary Maximum Contaminant Levels (SMCL), as well as EPA Health-based Standards Drinking Water Advisories. Health-based standards were exceeded for arsenic in 22 percent, sodium in 20 percent, and nitrates in 2 percent of the monitoring wells sampled. Aesthetically based standards were exceeded for total dissolved solids in 33 percent, chloride in 11 percent, iron in 85 percent, and manganese in 30 percent of the wells sampled. Many of these same constituents, such as arsenic, iron, and manganese, are naturally occurring but become elevated in areas that have anoxic, mixed, and suboxic conditions. Some areas of potential vulnerability to anthropogenic-sourced constituents in the sand and gravel aquifers were evidenced by trace amounts of volatile organic compounds and pesticides detected in water-quality samples from shallow wells (total depth less of than 46 feet below land surface) near urban settings, and by the detection of elevated major ions (chloride, sodium, magnesium, and calcium) associated, in part, with road-salt applications. Source analysis for chloride indicates mixtures of road salt, water softeners, and sewage.

Continuously measured specific conductance values were used as a surrogate for continuously measured chloride concentrations in the groundwater. The estimated chloride concentrations generally were highest in spring and lowest in summer, and occasionally peak during spring melt. Overall, the range of concentrations varied depending on the local thickness and hydraulic conductivity of the aquifer.

Water levels and water quality from the countywide groundwater monitoring network were compared to water levels and water-quality results in 1979 from a previous U.S. Geological Survey study. Potentiometric surface maps show areas with inferred decreases of water levels near the southern and southeastern areas of McHenry County. Significant increases were noted for total dissolved solids and specific conductance. Chloride concentrations increased as much as 521 percent in three of six wells resampled in 2015 from the previous study. 


\section{Introduction}

Sand and gravel aquifers (groundwater) are the primary source of drinking water for all of McHenry County in northeastern Illinois (fig. 1). Local water managers have concerns about water availability and water quality issues as the population grows and more land areas are developed. Current and potential water resource issues in the county include water shortages, degradation of drinking-water quality, and increased storm-water runoff. These concerns led County planners to create a Groundwater Resource Management Plan (GRMP) to assist water managers, municipal officials, and the public in understanding and protecting their present and future groundwater supply (McHenry County Planning and Development, 2006). This plan led to the installation of a countywide groundwater monitoring network to provide water managers and the public with continuous real-time water levels transmitted to the Internet through a satellite to provide information on the status of the water resources in the county (fig. 1). The McHenry County Planning and Development Committee involved State and Federal agencies to equip established Illinois State Geological Survey (ISGS) monitoring wells (fig. 1) with pressure transducers, antennae, data-collection platforms, and solar panels for transmitting the data to the U.S. Geological Survey (USGS) National Water Inventory System (NWIS) Web interface (2017) (http://waterdata.usgs.gov/nwis). Additional McHenry County monitoring wells (fig. 1) were installed and equipped with pressure transducers and real-time equipment to complete the network. Together, this network of wells is referred to as the McHenry County groundwater monitoring network (MCGMN).

The GRMP generated a series of five assessment reports that were completed by the GRMP task force: Baxter and Woodman, Incorporated; Environmental Planning and Economics, Incorporated; Ayres Associates; Planning and Management Consultants, Incorporated; and Adrian Visocky (Groundwater Resources Management Plan Task Force, 2006). Recommendations of the five reports included:

1. Compile detailed hydrogeologic information of the groundwater resource at local and regional scales,

2. Identify the effects of land use on water levels and water quality, and

3. Assess the fate and transport of chloride and agricultural chemicals in the groundwater.

To supplement the information presented in the reports generated by the GRMP, and incorporate the data collected as part of the monitoring network, the USGS, in cooperation with McHenry County, Illinois, and in collaboration with the McHenry County Planning and Development Committee, completed a study to assess the hydrogeology and water quality of the sand and gravel aquifers. This assessment included identifying influences on groundwater levels, the degree of aquifer confinement and interconnection, areas of recharge and discharge, and evaluating current water quality and comparing it to historical (1979) data.

First, water-level influences from precipitation, seasonal and annual changes, barometric pressure, geology, and pumping were identified and used to determine the hydrogeologic setting, which includes the degree of aquifer confinement (aquifer type) and interconnection, areas of recharge and discharge (calculated from vertical gradients), and recharge quantities (estimated from water-table fluctuation) for the period of study (2009-14). Second, in 2010 , the effects on water quality and quantity from urbanization and agricultural practices were investigated through a comprehensive collection of water-quality samples from the MCGMN plus four additional USGS monitoring wells available from the ongoing USGS National Water-Quality Assessment (NAWQA) program. A fifth well from the NAWQA program with real-time monitoring equipment also was included in the MCGMN for this study. Finally, a comparison of water levels and water quality was completed to assess changes in the quantity and quality within the sand and gravel aquifers since 1979 .

\section{Purpose and Scope}

This report describes hydrogeology and water quality of sand and gravel aquifers in McHenry County, Illinois, during 2009-2014 and comparisons to conditions in 1979. Specifically, the purpose of this report is to:

1. Identify the local and regional hydrogeology (degree of aquifer confinement, interconnections, areas of recharge and discharge) of the uppermost sand and gravel aquifers based on continuous water-level responses,

2. Determine areas of the aquifers that are affected by pumping,

3. Describe the status of groundwater quality in 2010 ,

4. Identify the potential sources of chloride and assess the seasonal trends of chloride, and

5. Determine whether statistically significant changes in groundwater levels and quality have occurred since 1979.

This report describes and summarizes the findings from the analysis of the 44 monitoring wells that have been continuously monitoring water levels from 2009 to 2014 and from 5 of these wells where specific conductance had been continuously collected from 2011 to 2014. Water-quality samples were obtained from 41 monitoring wells from the MCGMN, plus five USGS NAWQA wells from June through October 2010. Periodic water-quality data, including specific conductance and chloride, were collected from 2010-14 from selected monitoring wells. Hydrograph analysis and other hydrogeologic characteristics are described in detail. 


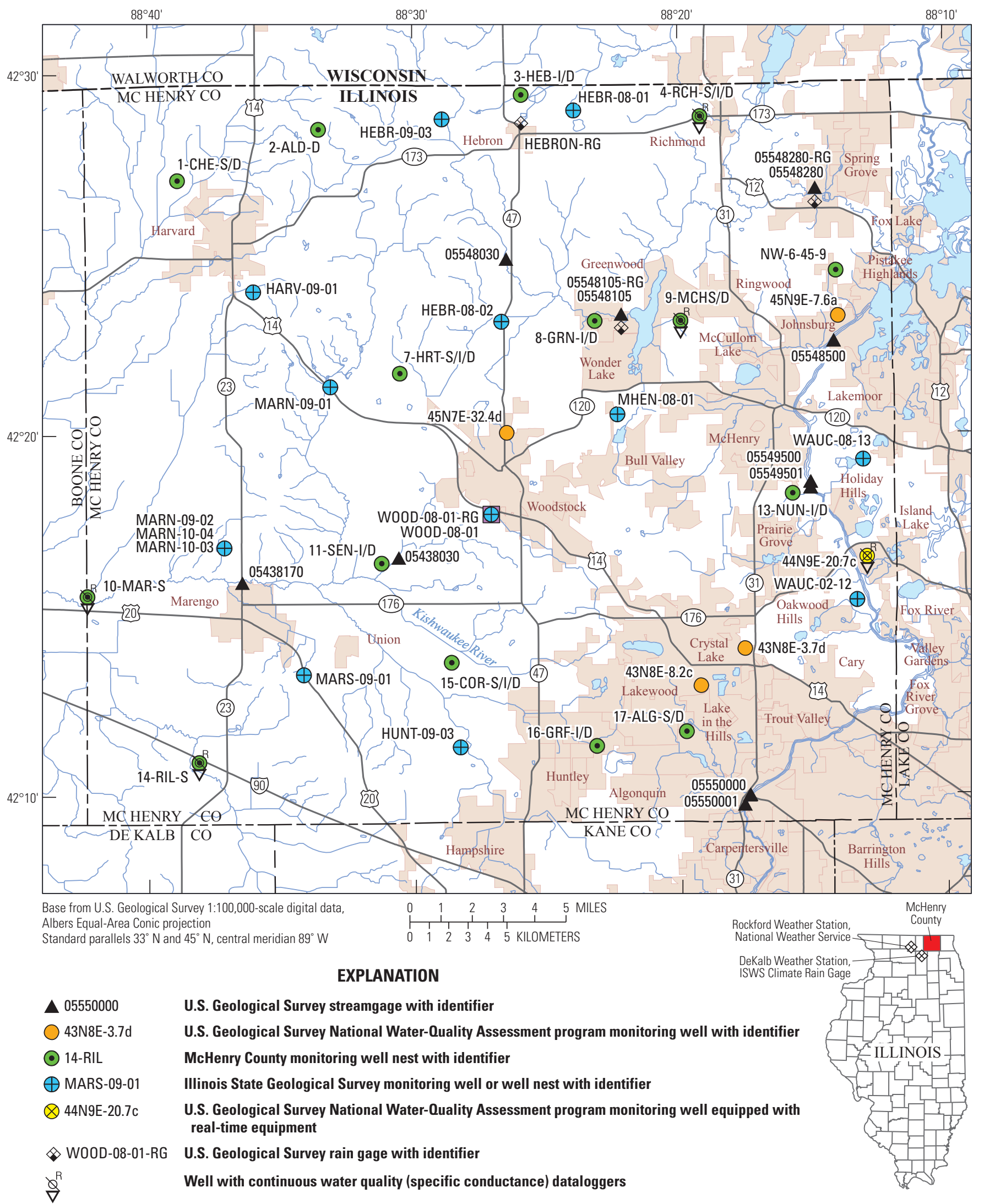

Figure 1. Groundwater monitoring wells, streamgages, and rain gages in McHenry County, Illinois. 
The report can be used as a guide to evaluate continuous water-level data to determine natural and anthropogenic influences on water levels in monitoring wells.

\section{Description of Study Area}

The study area covers the extent of McHenry County (611 square miles $\left[\mathrm{mi}^{2}\right]$ ) in northeastern Illinois. The county is approximately $25 \mathrm{mi}$ northwest of the Chicago metropolitan area. Substantial population growth in the county over the past several years follows the overall trend of urban sprawl. The residential population in McHenry County increased from 147,897 in 1980 to 308,760 in 2010, a 108-percent increase (U.S. Census Bureau, 2010). The population is expected to increase by another 66 percent by year 2040 according to the Chicago Metropolitan Agency for Planning (Chicago Metropolitan Agency for Planning, 2012). Differences in how land cover have been categorized over the years makes it difficult to compare land cover from several decades ago to that of recent years. However, in just the period from 2001 to 2011, years in which comparable data could be obtained, land-cover data in the county indicate that increasing population has resulted in the conversion of forested and agricultural lands to developed (urban) areas. Total developed land increased from 76,735 acres to 90,781 acres, whereas forested lands decreased by 1,454 acres (U.S. Geological
Survey, 2015), and total agricultural land (pasture and cultivated crops) decreased by 12,786 acres (table 1 ). However, agricultural land remained the dominant land use in 2011, comprising 61 percent of the county area.

McHenry County is generally geographically split by type of land use. The western half of the county is dominated by agricultural lands, whereas the eastern half primarily is urban lands. Agricultural lands are primarily corn and soybean, with constructed drain tile installed in many low-lying areas (McHenry County Planning and Development, 2004; Baxter and Woodman, Inc., 2006). Common agricultural practices include the application of fertilizers, pesticides, and herbicides to the soil (Baxter and Woodman, Inc., 2006). Irrigation is common in much of the western half of McHenry County (fig. 2). Urban areas alter the hydrology through increased impervious areas and pumping of high-capacity municipal- and industrial-supply wells. Impervious areas, primarily pavement and building roofs, decrease the amount of precipitation entering the groundwater system (recharge) and increase the runoff toward streams where there are curbed streets and stormwater management systems. Road characteristics contribute to redirecting road runoff into drainage ditches on the sides of the road. The western half of the county generally uses private (residential) supply wells and septic systems, and the eastern half generally is provided centralized water through municipal supplies and is served by separate sanitary sewers and stormwater management systems.

Table 1. Land-cover type, acreage, and percentage of change in McHenry County, Illinois, 2001-11.

[Data from U.S. Geological Survey (2015)]

\begin{tabular}{|c|c|c|c|c|c|c|}
\hline \multirow{2}{*}{$\begin{array}{l}\text { Land-cover } \\
\text { type }\end{array}$} & \multicolumn{2}{|c|}{2001} & \multicolumn{2}{|c|}{2011} & \multicolumn{2}{|c|}{ Change 2001-11 } \\
\hline & Acres & Percent & Acres & Percent & Acres & Percent \\
\hline \multicolumn{7}{|l|}{ Developed } \\
\hline Open space & 25,415 & 7 & 32,717 & 8 & 7,302 & 2 \\
\hline Low intensity & 39,683 & 10 & 43,952 & 11 & 4,270 & 1 \\
\hline Medium intensity & 8,758 & 2 & 10,535 & 3 & 1,777 & 0.5 \\
\hline High intensity & 2,879 & 1 & 3,577 & 1 & 698 & 0.2 \\
\hline Combined & 76,735 & 20 & 90,781 & 23 & 14,047 & 3.7 \\
\hline \multicolumn{7}{|l|}{ Forest } \\
\hline Deciduous & 40,488 & 10 & 39,241 & 10 & $-1,247$ & -0.3 \\
\hline Evergreen & 192 & 0.1 & 229 & 0.1 & 37 & 0.0 \\
\hline Mixed & 4,041 & 1 & 3,797 & 1 & -244 & -0.1 \\
\hline Combined & 44,721 & 11 & 43,267 & 11 & $-1,454$ & -0.4 \\
\hline \multicolumn{7}{|l|}{ Agricultural } \\
\hline Shrub/scrub & 529 & 0 & 552 & 0 & 23 & 0.0 \\
\hline Barren land & 2,109 & 1 & 2,620 & 1 & 511 & 0.1 \\
\hline Hay/pasture & 52,601 & 13 & 48,162 & 12 & $-4,439$ & -1 \\
\hline Cultivated crops & 195,358 & 50 & 186,477 & 48 & $-8,881$ & -2 \\
\hline Combined & 250,597 & 64 & 237,811 & 61 & $-12,786$ & -2.9 \\
\hline \multicolumn{7}{|l|}{ Wetlands } \\
\hline Open water & 6,709 & 2 & 7,299 & 2 & 590 & 0.2 \\
\hline Woody wetlands & 5,282 & 1 & 5,102 & 1 & -180 & 0.0 \\
\hline Herbaceuous wetland & 5,758 & 1 & 4,856 & 1 & -902 & -0.2 \\
\hline Emergent herbaceuous wetland & 1,166 & 0.3 & 1,852 & 0.5 & 685 & 0.2 \\
\hline Combined & 18,915 & 4.3 & 19,109 & 4.5 & 193 & 0.2 \\
\hline
\end{tabular}




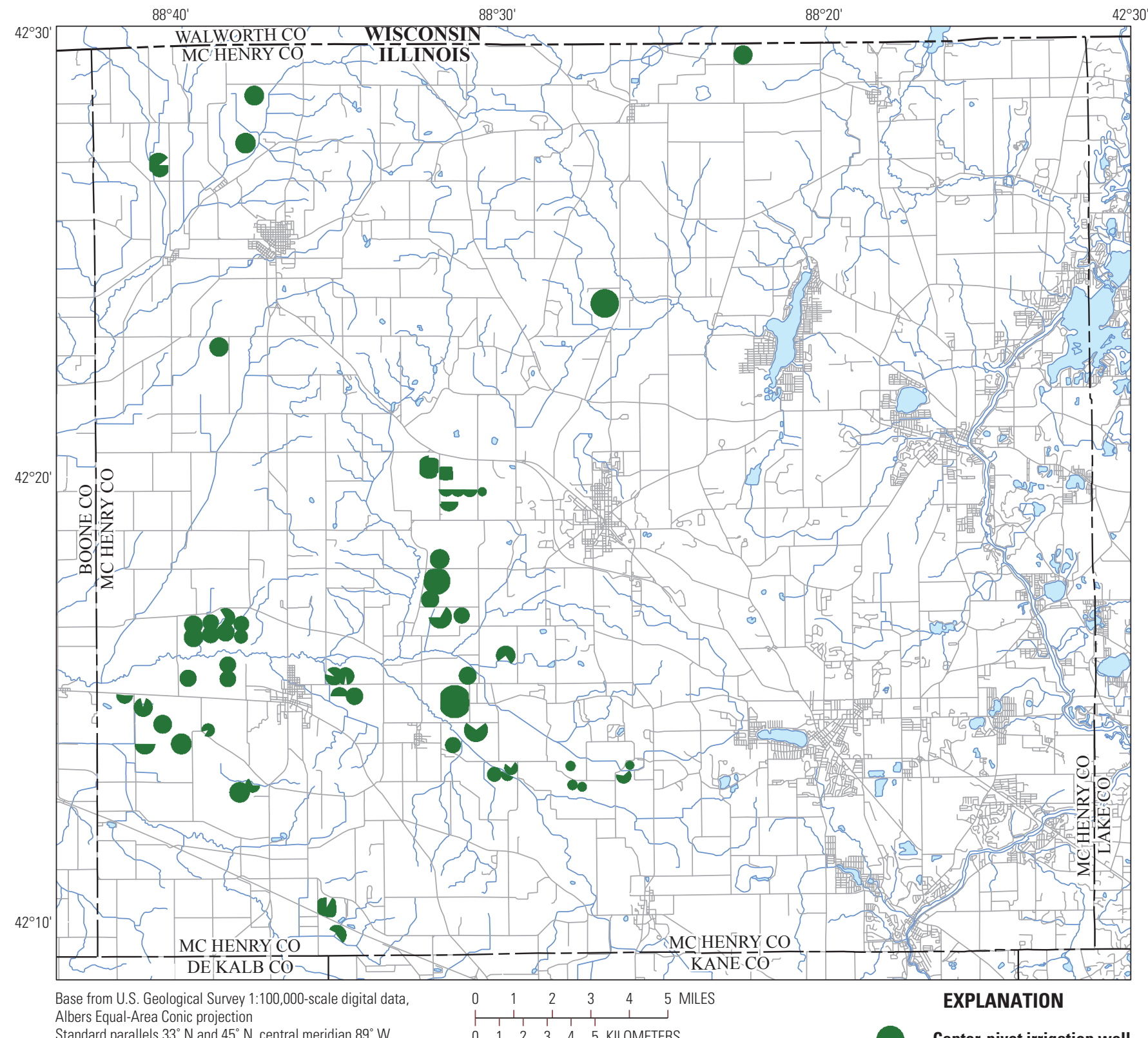

Standard parallels $33^{\circ} \mathrm{N}$ and $45^{\circ} \mathrm{N}$, central meridian $89^{\circ} \mathrm{W}$

Center-pivot irrigation well

Figure 2. Locations of center-pivot irrigation wells in McHenry County, Illinois.

The average annual precipitation (2009-14) for

McHenry County is 30.4 inches (in.) and ranged from 28.61 to 31.74 in., according to three rain gage stations in the county (HEBRON-RG, 05548105RG, and 05548280-RG) (fig. 1; U.S. Geological Survey National Water Information System, [U.S. Geological Survey, 2017]). This is consistent with, but slightly less than, the Illinois State Water Survey Climate rain gage in DeKalb, which recorded an annual average precipitation of 36.92 inches per year (in/yr) from 2009 to 2014 (Illinois State Water Survey, 2016).

Curry and others (1997) reported that the region is hilly and land-surface elevations range from about $700 \mathrm{ft}$ to about 1,200 ft above mean sea level. Elevations in figure 3 are referenced to North American Vertical Datum of 1988 (NAVD 88). Several glacial advances and retreats occurred in the McHenry County area during the Quaternary Period. This helped to produce the topographic high relief structures such as moraines, kames, and eskers, which are distributed throughout the region and separated by relatively flat outwash planes and undulating till plains (Hackett and McComas, 1969; Curry and others, 1997; Stiff and Hansel, 2004).

Surface water drains to the east in the Fox River watershed and to the west in the Kishwaukee River watershed (fig. 3). The Fox River, including its major tributary Nippersink Creek, has a drainage area of about $303 \mathrm{mi}^{2}$ in the county and flows southward to the 


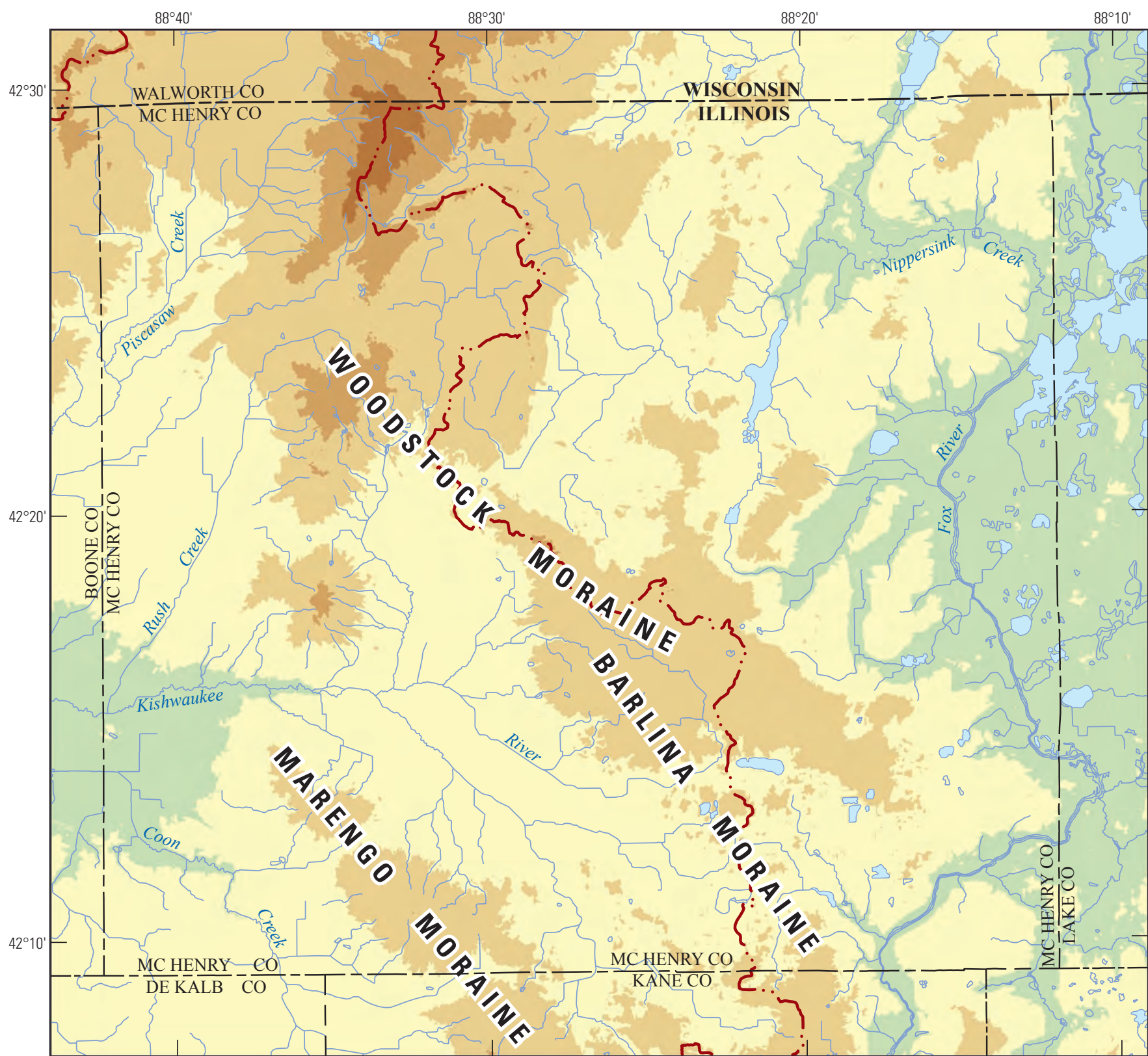

Base from U.S. Geological Survey 1:100,000-scale digital data, Albers Equal-Area Conic projection

Standard parallels $33^{\circ} \mathrm{N}$ and $45^{\circ} \mathrm{N}$, central meridian $89^{\circ} \mathrm{W}$.

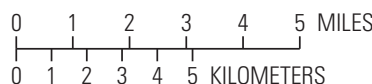

EXPLANATION

Elevation from U.S. Geological Survey National Elevation

Dataset (NED), 10-meter resolution, February 2013.

Drainage divide from U.S. Department of Agriculture

Watershed Boundary Dataset (WBD), February 2015

American Vertical Datum of 1988

700 to 800

801 to 900

901 to 1,000

1,001 to 1,100

1,101 to 1,200

Drainage divide between

Kishwaukee River to the west and Fox River to the east

Figure 3. Major waterways, moraines, and land surface elevations in McHenry County, Illinois. 
Illinois River (outside of study area, not shown). The Kishwaukee River and its tributaries (Coon, Rush, and Piscasaw Creeks) have a combined drainage area of about $308 \mathrm{mi}^{2}$ in the county and flow westward toward the Rock River (outside of study area, not shown). The Woodstock Moraine and the Barlina Moraine in south-central McHenry County act as a drainage divide between the Fox and Kishwaukee River Basins (Nicholas and Krohelski, 1984; Curry and others, 1997; Brown, 2002).

The shallow bedrock in McHenry County consists of weathered dolomite rocks of the Silurian age, the Maquoketa Group, and the Galena and Platteville Groups (Kolata and Graese, 1983). Stratigraphic nomenclature used in this report is that of the Illinois State Geological Survey (Willman, 1971; Meyer and others, 2013) and does not necessarily conform to usage of the USGS. The bedrock surface dips gently from west to east into the Michigan Basin (Meyer and others, 2013).

Overlying the bedrock is glacial drift of variable thickness that includes coarse-grained deposits, such as sands and gravels deposited by glacial meltwaters, and fine-grained deposits, primarily clay-rich glacial tills, deposited by glacial ice. These sediments were deposited and reworked by at least four major glaciations during the Quaternary Period (Stiff and Hansel, 2004; Larson and Herzog, 2010) and created a heterogeneous sequence of alternating layers of coarse- and fine-grained deposits. Aquifers in the glacial drift occur in the coarse-grained deposits under three general hydrogeologic settings: (1) unconfined (near surface with no overlying fine-grained layer of low permeability and represents the water table), (2) confined (deeper and overlain by one or more fined-grained layers of low-permeability layers), and (3) semi-confined (thin or discontinuous fine-grained layers of low-permeability) (fig. 4).
The names of the water-bearing units (referred to as aquifer units) are identified and described by Meyer and others (2013) and are used in this report for consistency purposes. The water-bearing units represented in the groundwater network are (deepest to shallowest):

- Bedrock aquifer,

- Lower Glasford Sand Unit,

- Upper Glasford Sand Unit,

- Ashmore Unit,

- Yorkville-Batestown Unit, and

- Haeger-Beverly Unit.

The aquifers are separated by discontinuous, low permeability till deposits of variable thickness that inhibit the flow of groundwater. These till units consist primarily of clay. These confining units from deepest to shallowest are the Lower Glasford Unit, which overlies the Lower Glasford Sand Unit; the Winnebego-Upper Glasford Unit, which overlies the Upper Glasford Sand Unit; and the Tiskilwa Unit, which overlies the Ashmore unit (Meyer and others, 2013). The Wadsworth Unit is the shallowest of the Quaternary deposits; however, it is not present west of Lake County (Meyer and others, 2013).

A water table map was created with Surfer ${ }^{\circledR}$ software for the shallow (Haeger-Beverly Unit and Yorkville-Batestown Unit) and intermediate (Ashmore Unit and Upper Glasford Sand Unit) wells using the geometric mean water-level elevations for 2009-14 for each monitoring well location (fig. 5). Water-level data are available in the USGS National Water Information System (U.S. Geological Survey, 2017). The geometric mean is the central tendency of a series of values and, therefore, is resistant to outliers. Water-table elevations ranged from 733 to $956 \mathrm{ft}$ above NAVD 88.

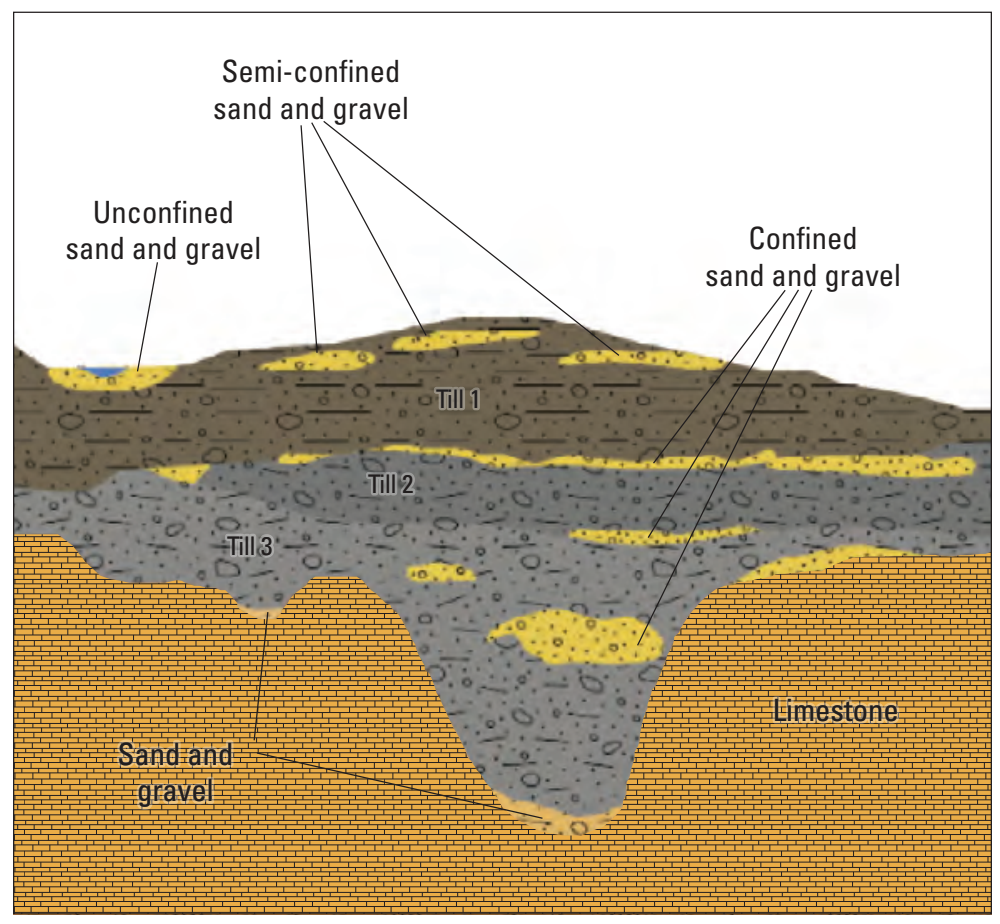

Figure 4. Conceptual drawing of alternating sand and gravel deposits and till deposits under the three general hydrogeologic settings (aquifer type) commonly found in the subsurface of McHenry County, Illinois (modified from Kerr and others, 2015). 


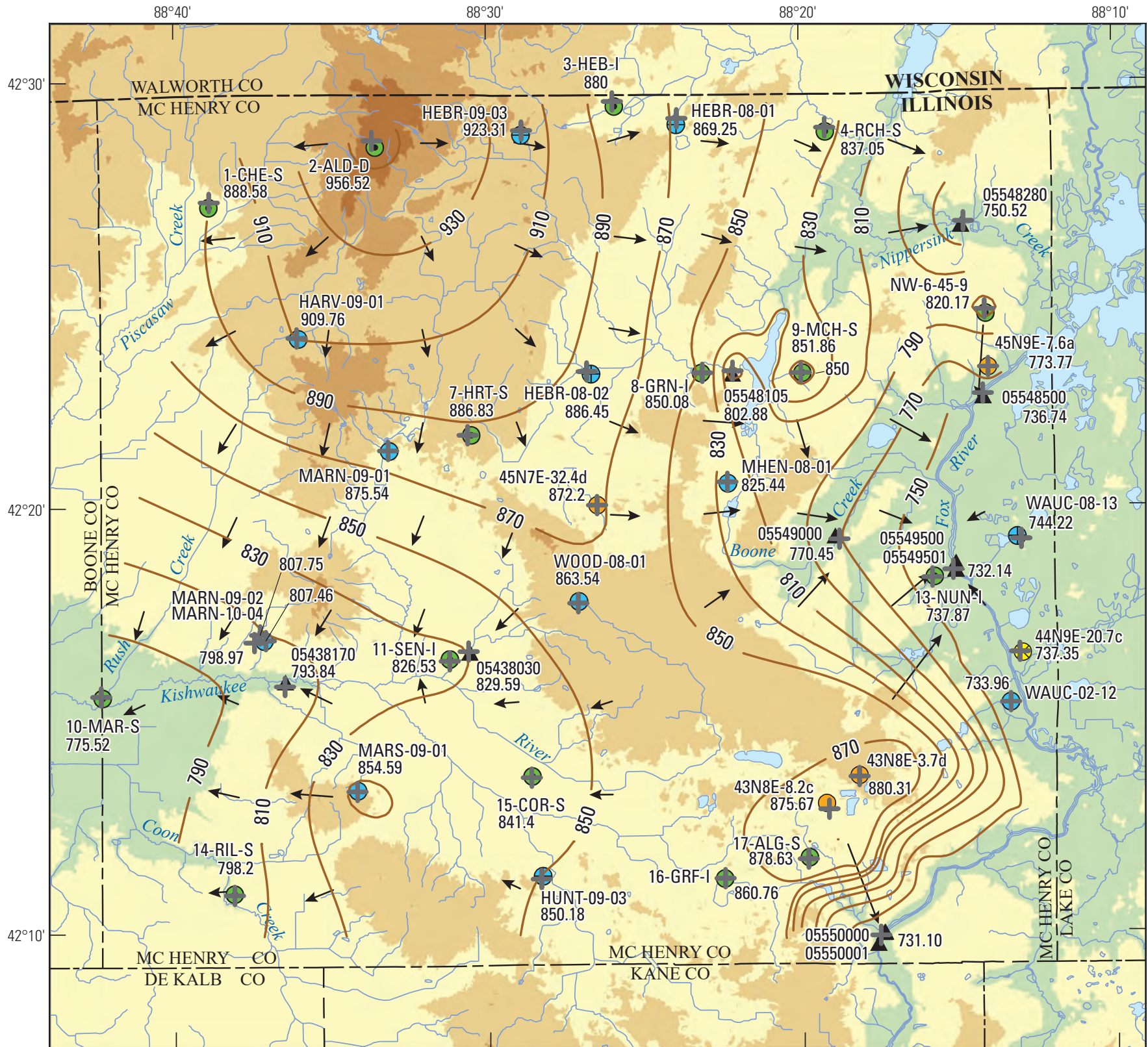

Base from U.S. Geological Survey 1:100,000-scale digital data, Albers Equal-Area Conic projection

Standard parallels $33^{\circ} \mathrm{N}$ and $45^{\circ} \mathrm{N}$, central meridian $89^{\circ} \mathrm{W}$ Elevation from U.S. Geological Survey National Elevation

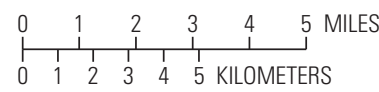 Dataset (NED), 10-meter resolution, February 2013. 700 to 800
801 to 900
901 to 1,000
1,001 to 1,100
1,101 to 1,200
Potentiometric contour, interval is 20 feet
Elevation, in feet above North American Vertical Datum of 1988
$\longleftarrow$ Direction of flow-Length of arrow indicates steepness of gradient
†841.4 Geometric mean water level for period of record (2009-14)
A $05550000 \quad$ U.S. Geological Survey streamflow-gaging station with identifier
43N8E-3.7d U.S. Geological Survey National Water-Quality Assessment Program well with identifier
14-RIL McHenry County observation well nest with identifier
$\bigoplus$ MARS-09-01 Illinois State Geological Survey observation well or well nest with identifier
$\bigotimes 44 N 9 E-20.7 c \quad$ U.S. Geological Survey National Water-Quality Assessment Program well equipped with real-time equipment

\section{EXPLANATION}

Figure 5. Flow directions and water levels of shallow wells in the McHenry County groundwater monitoring well network, McHenry County, Illinois. 
Arrows, with longer tails indicating a steeper gradient, designate flow directions. Like stream drainage, the horizontal direction of groundwater flow in the shallow to intermediate part of the glacial deposits is divided along a slightly central, north-to-south trending transect coinciding with the Woodstock and Barlina Moraines. East of the moraines, flow generally is east toward the upper Fox River; west of the moraines, flow is southwest toward the Kishwaukee River. Groundwater flow toward the upper Fox River drains much of the developed area of McHenry County. Groundwater flow toward the Kishwaukee River drains much of the agricultural land of the county.

\section{Water Use and Population Growth}

The USGS National Water Use Information Program (U.S. Geological Survey, 2016a) gathers water-use data from across the country every 5 years. The county-aggregated data for the oldest available data (1985) and most recent available data (2010) are presented in table 2 (U.S. Geological Survey, $2016 \mathrm{~b}$ and 2016c) along with McHenry County population data for 1985 and 2010 (U.S. Census Bureau, 2015). A self-supplied domestic well is a private residential well that pumps water directly from the ground to supply a household with water. Public-supply wells are larger wells owned and operated by a village, town, municipality, or private water company that pumps larger amounts of groundwater to supply an entire community or facility population with water. McHenry County withdraws smaller amounts of surface water (4.84 million gallons per day [Mgal/d]; U.S. Geological Survey, 2016c) compared to groundwater withdrawals of $31.71 \mathrm{Mgal} / \mathrm{d}$ in 2010 (table 2). Surface water is not used for drinking water purposes in McHenry County.

Self-supplied domestic withdrawals decreased by 11 percent from 1985 to 2010 . During this same period, the number of people using self-supplied domestic sources increased by only 6 percent compared to the increase in people obtaining drinking water from public-supply wells (an increase of 145 percent). Most of the increase in water use and population has been in the urban areas of McHenry County (shaded areas in figure 1, predominantly in the eastern part of the county). Total water use and population data from 1985 to 2010 for McHenry County are presented in figure 6 . Fluctuation in total water use is potentially because of the introduction of more efficient water fixtures, water conservation, economic stresses, county residents moving, or areas becoming communities with public water supply, and changes in data-compilation methods. Some of the fluctuation also may be attributed to variations in the water use reporting because of the lack of requirement to report water use data.
Table 2. Water withdrawals and populations served, McHenry County, Illinois, 1985 and 2010.

[Mgal/d, million gallons per day; -, no data]

\begin{tabular}{lcccccc}
\hline \multirow{2}{*}{$\begin{array}{c}\text { Water-use } \\
\text { category }\end{array}$} & \multicolumn{2}{c}{$\begin{array}{c}\text { Groundwater } \\
\text { withdrawals } \\
\text { (Mgal/d) }\end{array}$} & & & \multicolumn{2}{c}{$\begin{array}{c}\text { Population } \\
\text { served } \\
\text { (thousands) }\end{array}$} \\
\cline { 2 - 3 } \cline { 6 - 7 } & $\mathbf{1 9 8 5}$ & $\mathbf{2 0 1 0}$ & & $\mathbf{1 9 8 5}$ & $\mathbf{2 0 1 0}$ \\
\hline Public-supplied domestic & 12.21 & 19.97 & & 97 & 237 \\
Self-supplied domestic & 6.48 & 5.75 & & 68 & 72 \\
Irrigation & 1.29 & 2.77 & & - & - \\
Other ${ }^{1}$ & 1.9 & 3.22 & & - & - \\
\multicolumn{1}{l}{ Total } & 21.88 & 31.71 & & 165 & 309 \\
\hline
\end{tabular}

${ }^{1}$ Includes commercial, industrial, mining, livestock, and aquaculture. Descriptions of estimation methodology are available at http://water.usgs.gov/ watuse/data/index.html.

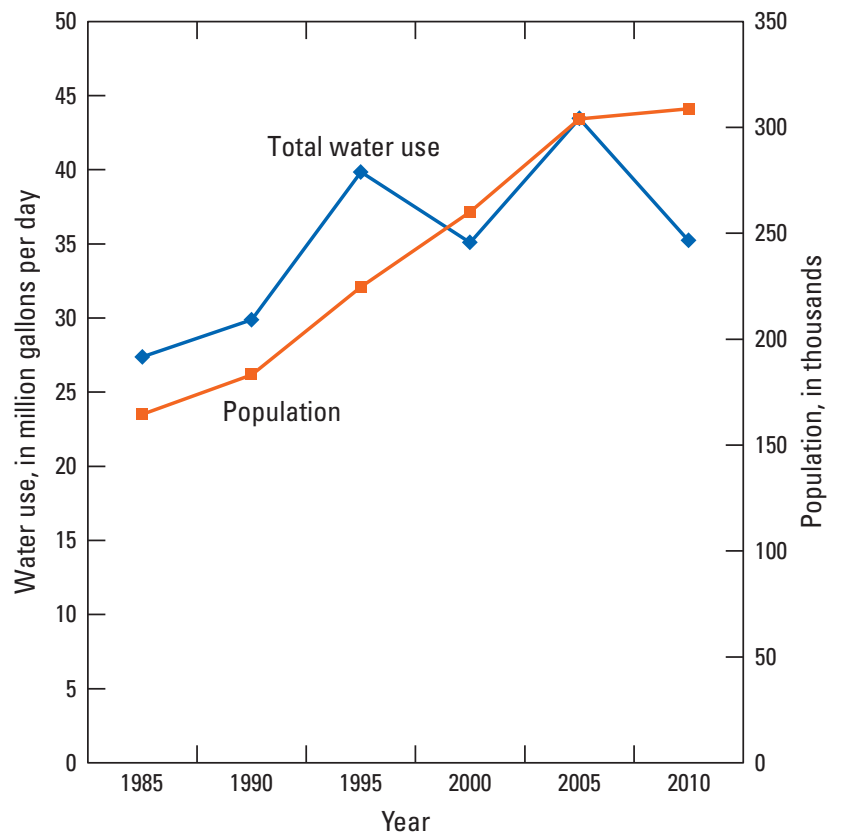

Figure 6. Population growth and total water use in McHenry County, Illinois, 1985-2010. Data are from the U.S. Geological Survey National Water Use Information Program. 


\section{McHenry County Groundwater Monitoring Network}

In 2008, 28 new monitoring wells (fig. 1; 11 co-located) were installed by McHenry County at 15 locations throughout the county to supplement the available ISGS wells (fig. 1). The monitoring wells, typically on McHenry County Conservation District property, were installed in various aquifers throughout the glacial drift. Two wells (17-ALG-D, 1-CHE-D) are screened in the upper $10 \mathrm{ft}$ of the bedrock and three wells (4-RCH-D, 7-HRT-D, 13-NUN-D) are screened across the interface between the glacial drift and the shallow bedrock. During February the 28 new monitoring wells were equipped with atmospherically vented pressure transducers that record water levels every 15 minutes and transmit them through a satellite to the World Wide Web every hour. In August 2009, fifteen (15) ISGS monitoring wells also were equipped with the aforementioned instrumentation. The data are presented on the USGS NWIS interface in the form of a hydrograph (a graph of depth to water/groundwater elevation over a period of time) for each monitoring well (http://waterdata.usgs.gov/ nwis) and are available to the public. The instrumentation are contained in a steel security box attached to the well housing and are self-powered with a battery and solar panel (fig. 7). Additionally, the USGS previously installed five monitoring wells near urban locations in McHenry County for the NAWQA program (fig. 1). Periodic manual water levels also were measured from four NAWQA wells located in McHenry County, and a fifth NAWQA well (44N9E-20.7c; fig. 1) with real-time monitoring equipment was included in the MCGMN for this study. The Meyer and others (2013) report included water levels from the MCGMN and USGS NAWQA monitoring wells to create water table and potentiometric surface maps for each of the aquifer units. The aquifer units represented by each of the MCGMN monitoring wells were identified from figures 40 through 46 in the Meyer and others (2013) report. The monitoring well construction information and aquifer unit represented by each of the 44 continuous water-level monitoring wells plus the four periodically (not continuous) measured NAWQA wells are shown in table 3.

Of the 44 continuously monitored wells, only one continuously monitored well (USGS NAWQA well 44N9E-20.7c) is located in an urban setting (fig. 1). Other wells that are nearby or adjacent to urban settings (17-ALG-S/D, 16-GRF-I/D, 9-MCH-S, WOOD-08-01, WAUC-08-3, 13-NUN-I/D, and NW-6-45-9; fig. 1) also are co-located on open lands for parks and wetland restoration areas. The percentage of each type of land use (agriculture

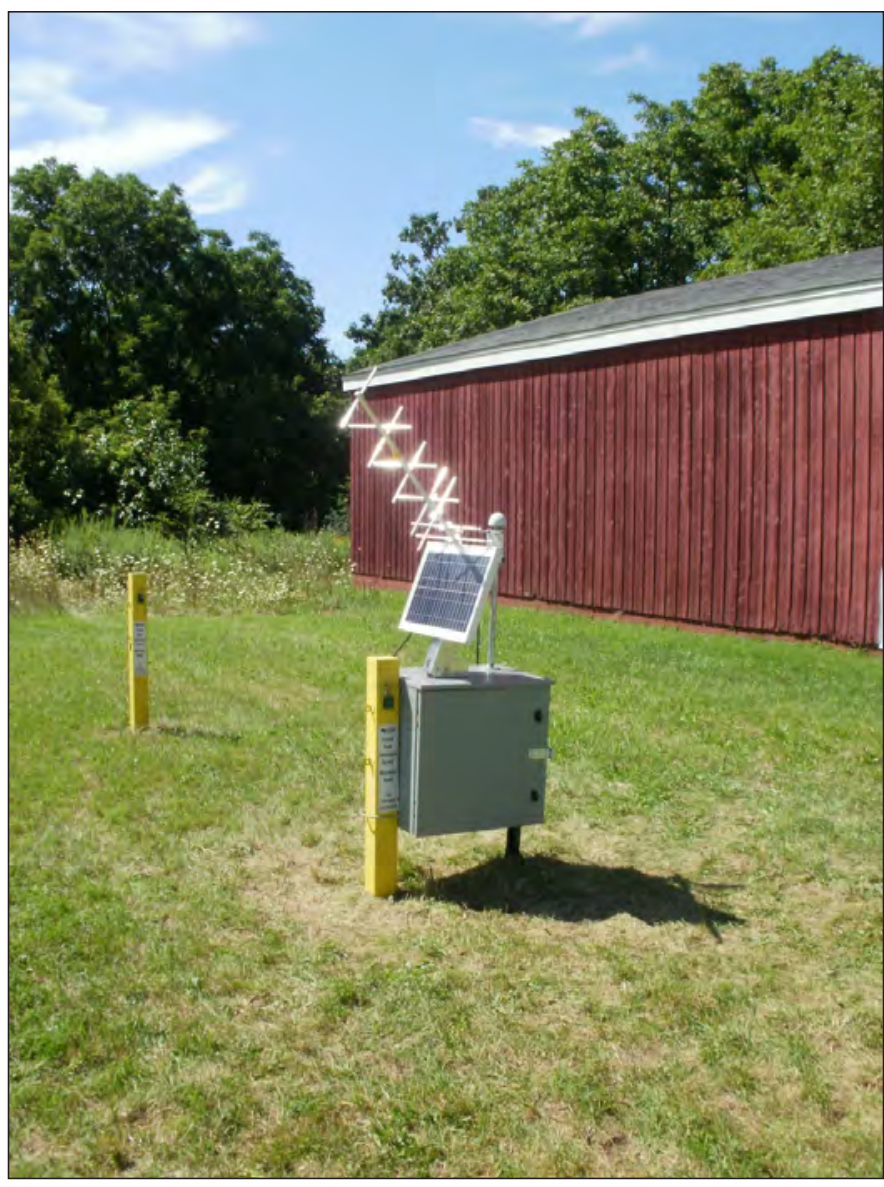

Figure 7. Real-time groundwater monitoring well in McHenry County, Illinois. Photograph by Mike Lee, U.S. Geological Survey, 2009.

or urban) in a 1,640-ft radius for each monitoring well nest is shown in table 4 . The relatively high percentage of agricultural land surrounding the monitoring wells is partly due to the placement of monitoring wells on McHenry County Conservation lands and easements that are primarily surrounded by a combination of open land and agriculture.

The period of data is different for each well, but in most cases, water-level data at 15 -minute intervals have been collected from 2009 to the present (2016). The data from 2009 to 2014 were used for much of the subsequent analyses presented in this report. The periodically collected discrete water-level data from four additional NAWQA wells also are included in the analyses for this report. 
Table 3. Construction of selected monitoring wells with water-level and water-quality data, and the identified aquifer unit, McHenry County, Illinois.

[Locations of monitoring wells are shown in figure 1. Aquifer unit: Determined by the Illinois State Water Survey (Meyer and others, 2013) and well logs obtained from the Illinois State Geological Survey (2016). Aquifer units at locations of monitoring wells installed by AECOM were determined by well depths (elevations) in association with interpolated locations on the hydrogeologic cross sections (figs. 19-28) and potentiometric surface maps for each aquifer unit (figs. 40-46) from Meyer and others (2013). Abbreviations: ft, foot; NAVD 88, North American Vertical Datum of 1988; No., number]

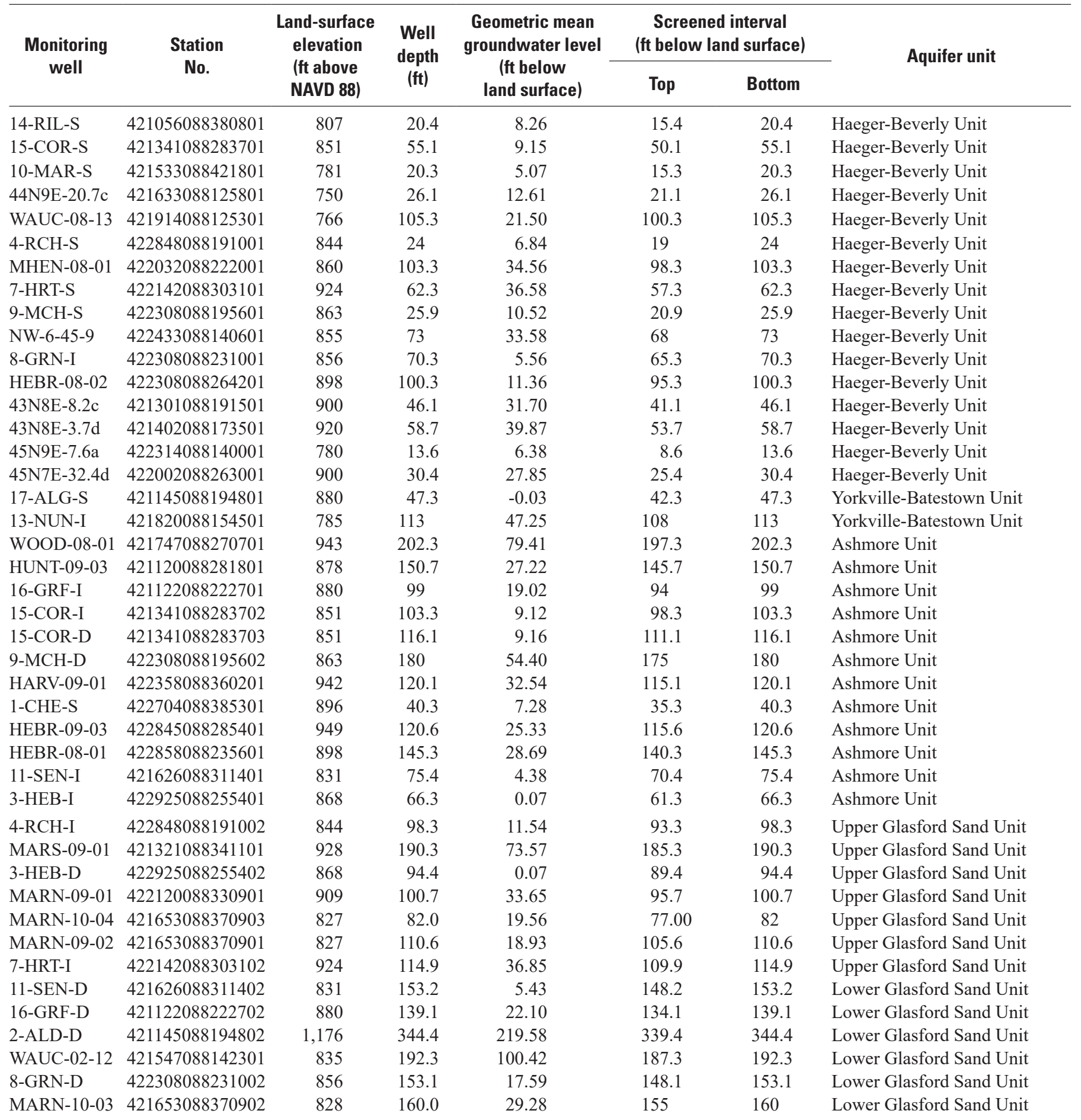


Table 3. Construction of selected monitoring wells with water-level and water-quality data, and the identified aquifer unit, McHenry County, Illinois.-Continued

\begin{tabular}{|c|c|c|c|c|c|c|c|}
\hline \multirow{2}{*}{$\begin{array}{l}\text { Monitoring } \\
\text { well }\end{array}$} & \multirow{2}{*}{$\begin{array}{l}\text { Station } \\
\text { No. }\end{array}$} & \multirow{2}{*}{$\begin{array}{l}\text { Land-surface } \\
\text { elevation } \\
\text { (ft above } \\
\text { NAVD 88) }\end{array}$} & \multirow{2}{*}{$\begin{array}{l}\text { Well } \\
\text { depth } \\
\text { (ft) }\end{array}$} & \multirow{2}{*}{$\begin{array}{c}\text { Geometric mean } \\
\text { groundwater level } \\
\text { (ft below } \\
\text { land surface) }\end{array}$} & \multicolumn{2}{|c|}{$\begin{array}{c}\text { Screened interval } \\
\text { (ft below land surface) }\end{array}$} & \multirow{2}{*}{ Aquifer unit } \\
\hline & & & & & Top & Bottom & \\
\hline 4-RCH-D & 422848088191003 & 844 & 176 & 11.32 & 171 & 176 & $\begin{array}{c}\text { Shallow Bedrock Aquifer and } \\
\text { Lower Glasford Sand Unit }\end{array}$ \\
\hline 13-NUN-D & 421820088154502 & 785 & 152.2 & 46.96 & 147.2 & 152.2 & $\begin{array}{c}\text { Shallow Bedrock Aquifer and } \\
\text { Lower Glasford Sand Unit }\end{array}$ \\
\hline 1-CHE-D & 422704088385302 & 899 & 110.8 & 10.11 & 105.8 & 110.8 & Shallow Bedrock Aquifer \\
\hline 17-ALG-D & 422828088333301 & 880 & 187.8 & 102.87 & 182.8 & 187.8 & Shallow Bedrock Aquifer \\
\hline
\end{tabular}

Table 4. Monitoring wells and percentage of agricultural and urban lands within a 1,640-foot radial buffer zone around each well in the McHenry County groundwater monitoring network, Illinois.

[Locations of monitoring wells are shown in figure 1]

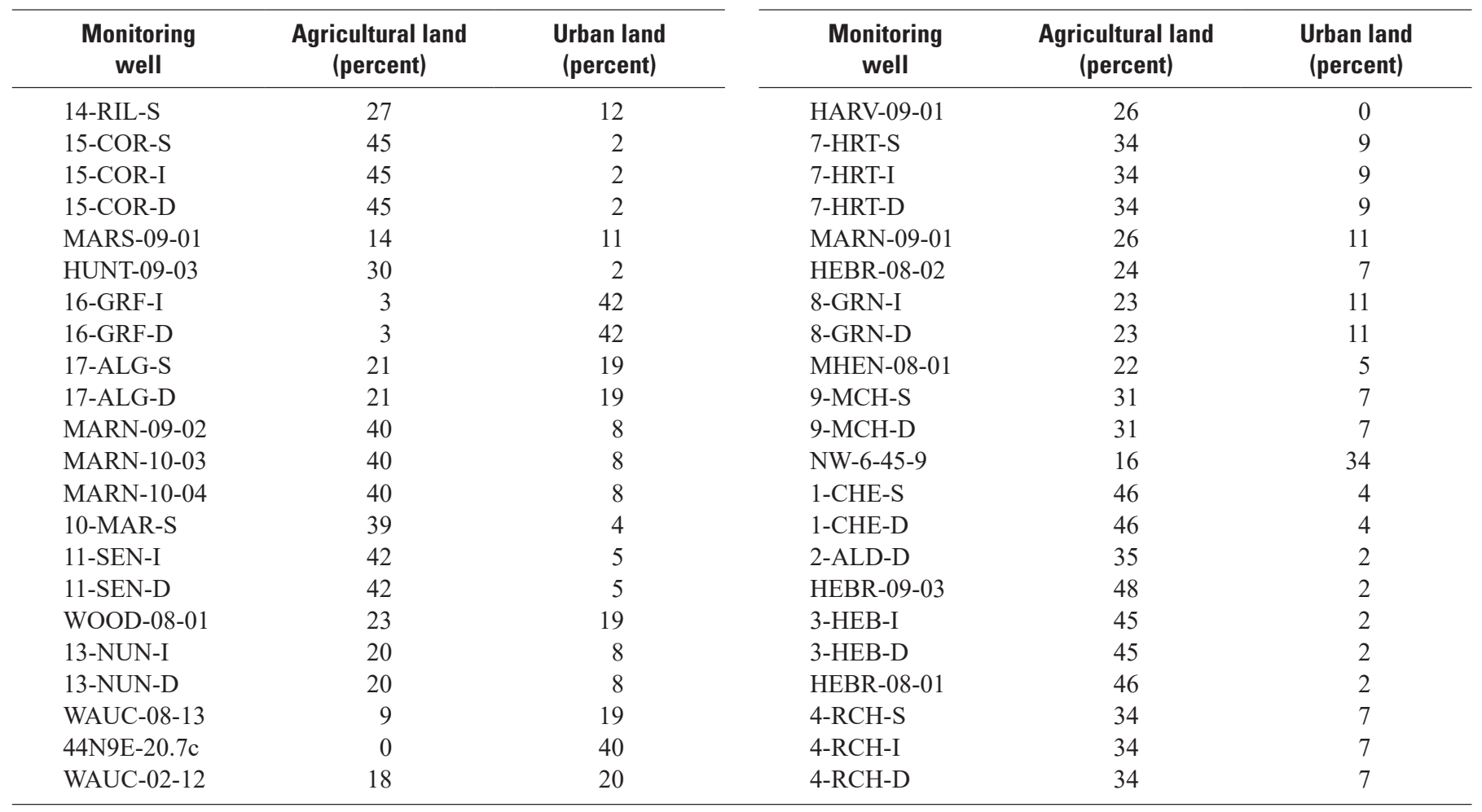




\section{Previous Investigations}

The complex geology and hydrogeology in McHenry County have been extensively investigated and reported on by the Illinois State Water Survey (ISWS), ISGS, and USGS in the following reports: Suter and others (1959); Csallany and Walton (1963); Nicholas and Krohelski (1984); Curry and others (1997); Meyer (1998); Meyer and others (2013); and Thomason and Keefer (2013).

Previous investigations related to groundwater resources in McHenry County include geologic mapping of the Quaternary lithostratigraphic units, a soil drainage map, and an aquifer sensitivity map (Curry and others, 1997), which provided information necessary for environmental planning and development as it relates to aquifer vulnerability. Measurements from 601 private, public, commercial, and industrial wells were used to create potentiometric surface maps for the discrete aquifer units and identified potential areas of aquifer unit interconnection (Meyer, 1998). The continuous water-level data from the MCGMN are used in this report to build on previous investigations and to serve as a baseline for future water level monitoring.

Water-quality assessments include various investigations of McHenry County municipal water supplies (Woller and Sanderson, 1976; Nicholas and Krohelski, 1984) and a water-availability assessment of residential water supply that was completed in Richmond, Illinois (Midwest Technology Assistance Center, 2009). A regional investigation of shallow groundwater quality in the Upper Illinois River Basin (Morrow, 2002) included the analysis of nine NAWQA monitoring wells and five residential supply wells in McHenry County. Additionally, the historical data from six NAWQA wells in McHenry County also were assessed for changes in water quality from 2000 to 2010 (Lindsey and Rupert, 2012). The water-quality samples collected in 2010 from the MCGMN, and the five NAWQA wells, creates a comprehensive assessment that can serve as a baseline for determining changes in water quality as the county continues to grow in population and urbanization.

\section{Methods}

This section describes methods used to measure groundwater levels and to interpret groundwater hydrographs. Water-quality sampling and analysis, including sampling procedures, data analysis, and quality assurance and quality control, are described.

\section{Measurement of Groundwater Levels}

Periodic water levels were measured manually by the USGS with an electronic measuring tape following procedures described in Cunningham and Schalk (2011). Continuous water levels were measured with atmospherically vented pressure transducers and recorded at 15-minute intervals following standard procedures, such as described in Freeman and others (2004).

Water levels measured by the USGS and recorded by the transducer represent depth to water from a referenced measuring point, in this case, the top of the well casing, also referred to as the "stick-up" of the monitoring well. The stick-up is subtracted from the depth to water reading to get a depth to water from land surface. The groundwater elevation is calculated by subtracting the depth to water from land surface elevation.

\section{Reading and Interpreting Groundwater Hydrographs}

Hydrographs are a graphical representations of water levels through time. Hydrograph water levels are displayed on NWISWeb (http://waterdata.usgs.gov/nwis) with the depth to water (in feet below land surface) on the left vertical axis (y-axis) and the groundwater elevation in feet above NAVD 88 on the right y-axis. Similarly, the groundwater hydrographs in this report generally present both the depth to water in feet below land surface on the left y-axis and groundwater elevation on the right y-axis. It is important to note that small (low values) depth to water measurements represent high water levels in the aquifer, whereas, large (high values) depth to water measurements represent low water levels in the aquifer. In this report, the depth to water is referred to as water level(s) with a few exceptions where noted.

Changes in the water levels can be caused by natural and anthropogenic influences. Natural influences considered in this report are precipitation and other climatic variables (such as barometric pressure and evapotranspiration) that affect the seasonal and annual variation in water levels. Geologic influences such as the presence and continuity of till units are also identified to determine the aquifer type. Anthropogenic influences may result in water-level fluctuation caused from the withdrawal (pumping) of groundwater by municipal supply wells, irrigation wells, industrial wells, or residential wells. Water-level changes from either natural or anthropogenic influences were used to identify the degree of aquifer confinement and interconnection; areas of groundwater recharge and discharge; and to estimate recharge quantities. All hydrographs were considered by calendar year. 
Precipitation that infiltrates through the unsaturated soil (vadose zone) and reaches the water table can cause the groundwater level to rise. A rapid response can result in extremely high and sharp peaks in the hydrograph. A temporally moderate response to recharge from precipitation in a hydrograph has rounded peaks indicating only a slight rise in water level followed by a gradual decrease after a precipitation event (Tedd and others, 2012). A muted response has either a sub-rounded peak or no peak in the hydrograph in response to precipitation. An example of rapid, moderate, and muted features of the hydrograph is shown in figure 8 . Although this qualitative approach requires inherent subjectivity, it is presented here to make hydrographic interpretations accessible to water managers and stakeholders.

A. 14-RIL-S
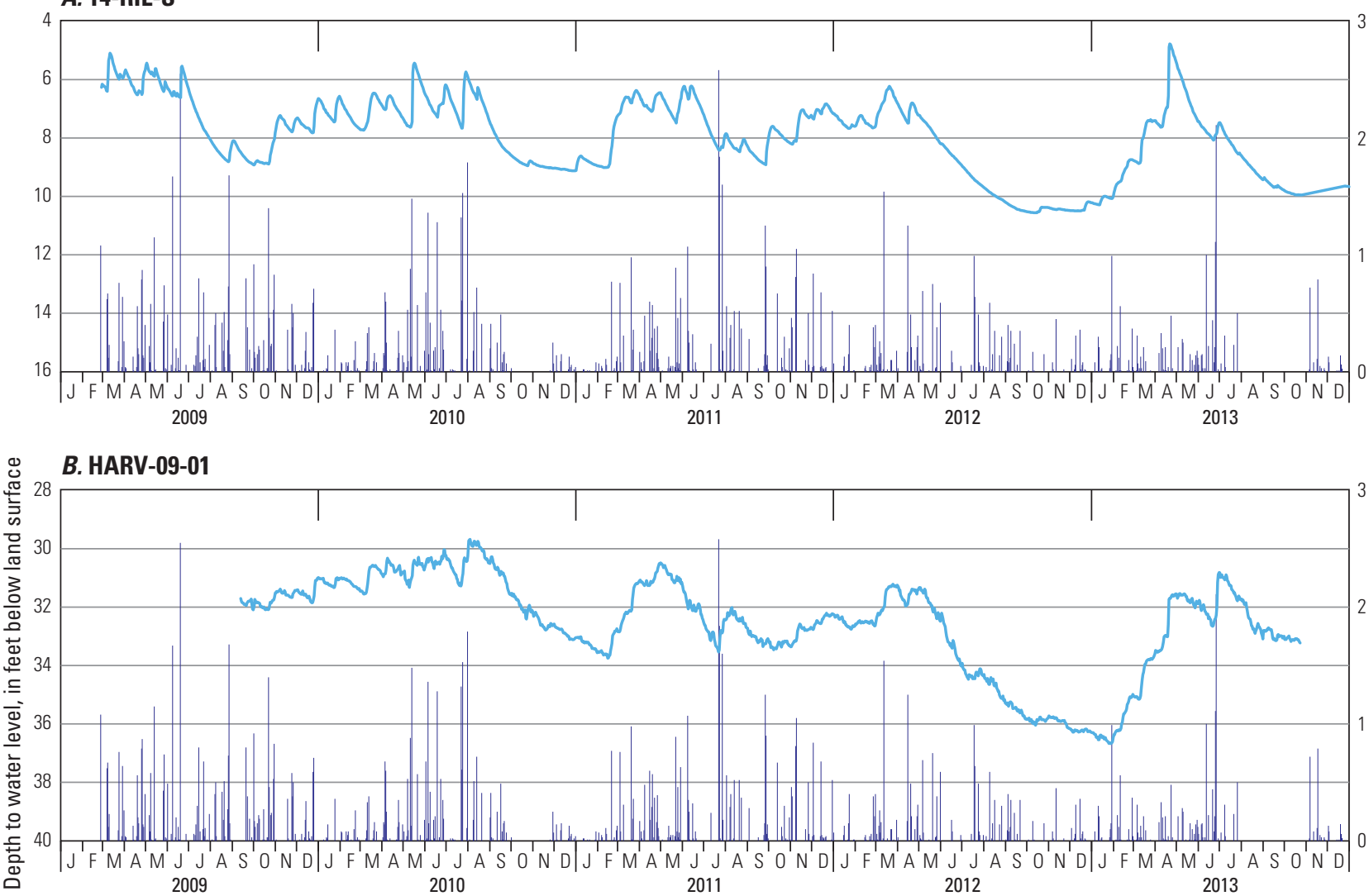

C. MARS-09-01

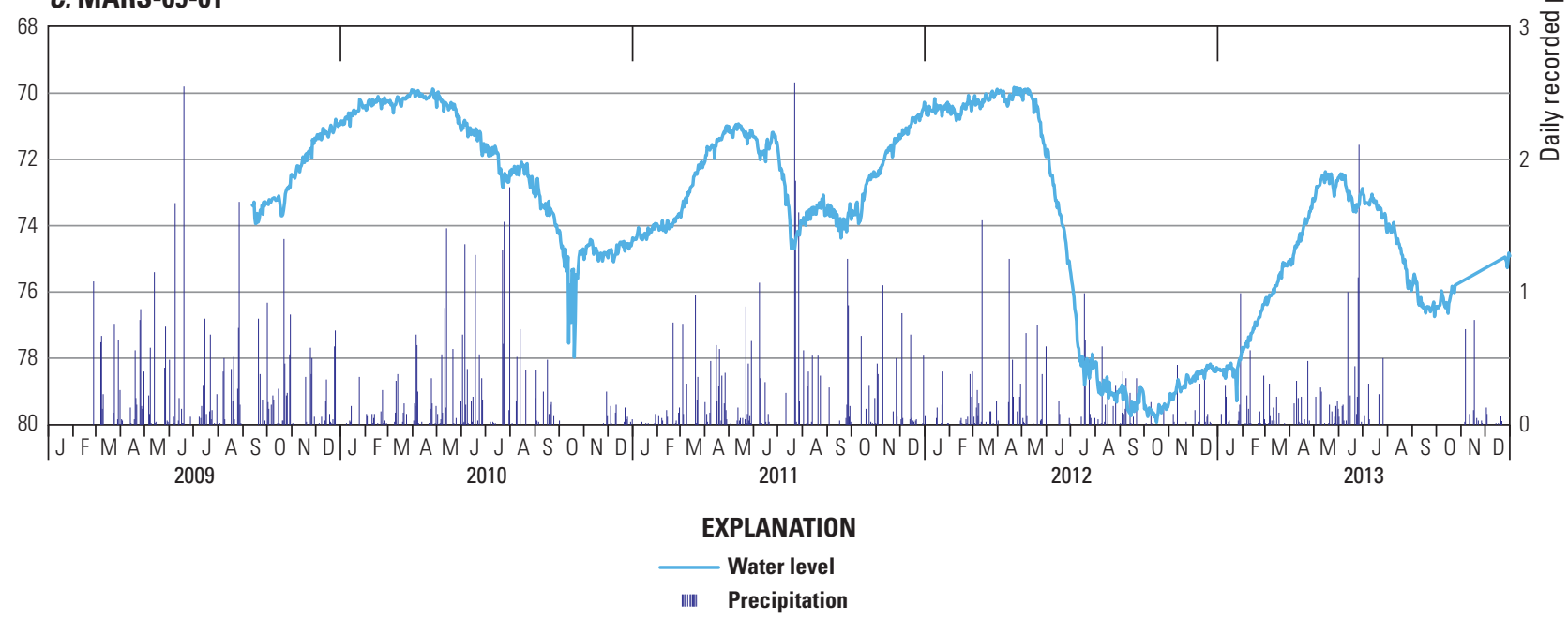

Figure 8. Examples of $(A)$ rapid, $(B)$ moderate, and $(C)$ muted responses to precipitation in selected wells in the McHenry County groundwater monitoring network, Illinois. 
The type of response also is related to the depth of the well, where shallow wells likely will respond rapidly to recharge and deep wells likely will respond more slowly to recharge (Tedd and others, 2012). Deviations from these expected responses are identified. The rapid, moderate, or muted categories are used to infer the degree of aquifer confinement and proximity to recharge areas.

Annual climatic variability is indicated by the seasonal peaks and troughs in the annual hydrographs for each monitoring well. Maximum aquifer storage level (highest water level) typically is reached during spring and early summer due to snowmelt, increased precipitation, and decreased evapotranspiration. In contrast, the minimum aquifer storage level (lowest water level) typically is reached during the autumn and winter, because of increased evapotranspiration and decreased precipitation. The magnitude of changes in annual variation of water levels due to wet years (above-average precipitation) and dry years (below-average precipitation) were spatially analyzed.

Geology reported in the monitoring-well construction logs also was viewed to determine the relative degree of aquifer confinement (aquifer type) (AECOM, 2009; Thomason and Keefer, 2013; appendix A: NAWQA well 44N9E-20.7c). The thickness of the overlying clay was noted in a decision matrix (table 5), along with additional information such as depth of well and water levels, to determine if the water level was above the top of the sand unit to which the well screen was open.

Table 5. Decision matrix to determine degree of confinement (aquifer type) from geology, water levels, and implications for water quality, McHenry County groundwater monitoring network, Illinois, 2009-14.

[From well logs (appendix A; AECOM, 2009; Thomason and Keefer, 2013). Geology: From well log. Abbreviations: ft, foot; >, greater than]

\begin{tabular}{|c|c|c|c|}
\hline Aquifer type & Geology & Water levels & Implications \\
\hline Unconfined & $\begin{array}{ll}\text { - } & \text { Sand } \\
\text { - } & \text { Gravel } \\
\text { - } & \text { Sand and gravel }\end{array}$ & $\begin{array}{l}\text { - } \\
\text { - } \quad \text { Close to land surface } \\
\text { - } \quad \begin{array}{l}\text { Do not respond to barometric } \\
\text { pressure changes }\end{array} \\
\text { - } \quad \begin{array}{l}\text { Generally respond rapidly or } \\
\text { moderately to precipitation }\end{array}\end{array}$ & $\begin{array}{l}\text { Vulnerable to contamination from } \\
\text { land surface, but likely receives } \\
\text { relatively rapid recharge } \\
\text { Water availability is generally } \\
\text { greater in unconfined aquifers as } \\
\text { opposed to confined aquifers }\end{array}$ \\
\hline Confined & $\begin{array}{l}\text { - Sand and (or) gravel } \\
\text { - Confined aquifers overlain by } \\
\text { thick ( }>30 \mathrm{ft} \text { ) layers of silt and } \\
\text { clay (till) }\end{array}$ & $\begin{array}{l}\text { - Separated by more than } 2 \mathrm{ft} \\
\text { from the other water levels within } \\
\text { nested wells. } \\
\text { - } \quad \text { Greater than top of sand unit } \\
\text { - } \quad \text { Have an inverse response to } \\
\text { barometric pressure changes } \\
\text { - Muted response to precipitation }\end{array}$ & $\begin{array}{l}\text { Generally less vulnerable to } \\
\text { contamination than unconfined or } \\
\text { semi-confined aquifers because } \\
\text { of depth within groundwater } \\
\text { system and presence of overlying, } \\
\text { relatively low-permeability } \\
\text { sediments } \\
\text { Water availability and extraction } \\
\text { rate may be limited }\end{array}$ \\
\hline
\end{tabular}


Water level responses to fluctuations in barometric pressure were used as another indicator of whether an aquifer was confined or unconfined. The magnitude of the water-level change is related to the degree of aquifer confinement and hydrogeologic framework (Butler and others, 2011). In a confined aquifer, the barometric pressure takes times to propagate through the saturated geologic material between the water table and the aquifer being monitored by a well. However, those changes occur almost instantaneously at the well, which is directly connected to the atmosphere. As a result of the difference in barometric pressure between the well and the aquifer, water will flow between the aquifer and the well, leading to an inverse water-level response (increases in barometric pressure will induce lower water levels, decreases in barometric pressure will induce higher water levels). In unconfined aquifers, the barometric pressure propagates downward through the vadose zone with limited resistance from the pore space. This occurs so quickly that the pressure difference in a well open to an unconfined aquifer is negligible, and thus produces no observable water-level responses from barometric pressure. In some cases, water-level responses to barometric pressure in unconfined wells may occur if the depth to water is large or if the conditions of the vadose zone delay the propagation of the barometric load (Butler and others, 2011).

Monitoring well WOOD-08-01 is in the center of the county (fig. 1) and is equipped with a portable weather station that collects data for precipitation, air temperature, barometric pressure, wind direction, wind speed, and humidity.
Hydrographs were compared to the barometric pressure readings at WOOD-08-01. Daily water levels and barometric pressures associated with each monitoring well hydrograph were analyzed using the Kansas Geological Survey Barometric Response Function software (Bohling and others, 2014). Graphs generated by the software that compare water levels to barometric pressure allowed identification of barometric effects (Bohling and others, 2014). The software-created graphs were analyzed with data collected over periods of 30 days or less to identify sites with an inverse relation between water levels and barometric pressure. Barometric pressure effects are evident when peaks in barometric pressure coincide with troughs in water level (fig. 9). If a hydrograph was determined to have barometric-pressure effects, the aquifer unit at that location was designated as confined.

Hydrographs from co-located (referred to in report as either "nests" or "nested") well sites also were used as an indication as to whether the aquifer is unconfined, semi-confined, or confined, and to assess the degree of interconnection between aquifer units. Interconnected aquifers may be at a greater risk for contamination (Metz and Brendle, 1996). Aquifer units with nearly the same water levels or water elevations (less than $1 \mathrm{ft}$ difference) through time are considered strongly interconnected. Identical water level responses to other influences such as precipitation and pumping are identified as strongly interconnected. Aquifer units with similar water levels (less than $5 \mathrm{ft}$ difference) over time and show identical water level responses to precipitation and pumping influences are considered moderately

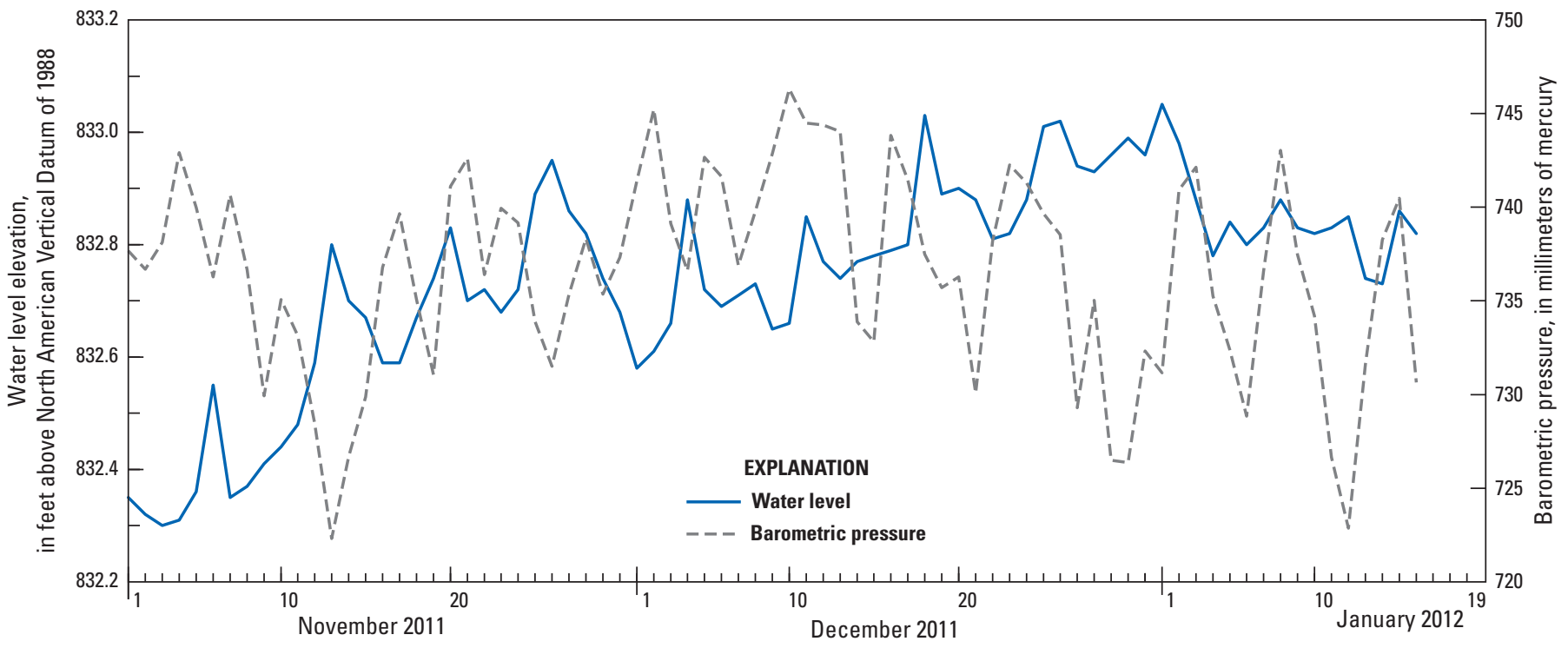

Figure 9. Example of inverse water-level responses to barometric pressure at monitoring well 4-RCH-D in McHenry County, Illinois. 
interconnected and identified as semi-confined. At locations where the interconnection occurs between the uppermost sand and gravel aquifers and the underlying aquifers, the uppermost sand and gravel aquifer is unconfined, and the deeper aquifer is semi-confined. Deeper sand and gravel aquifers that are interconnected are considered semi-confined.
Monitoring wells with distinctly different water levels indicate that the aquifer units represented are weakly interconnected, hydraulically isolated, and considered confined at that location. The difference between strongly interconnected, moderately interconnected, and weakly interconnected aquifers is shown in figure 10 .
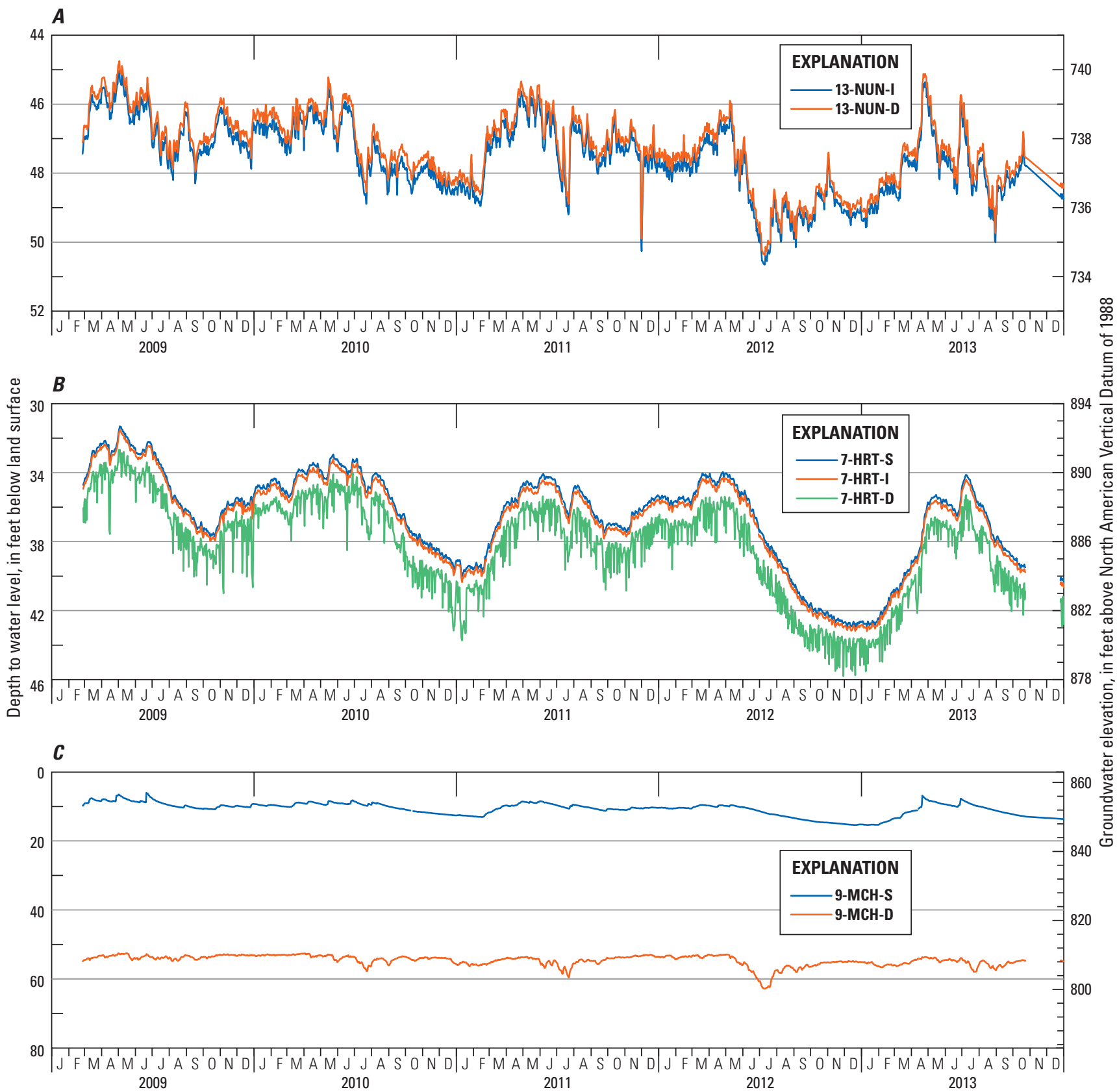

Figure 10. Examples of selected nested monitoring wells for $(A)$ strongly interconnected, $(B)$ moderately interconnected, and $(C)$ weakly interconnected aquifer units in McHenry County groundwater monitoring network, Illinois. 
Pumping influences were observed in hydrographs as water-level drawdown and recovery curves. An example from monitoring well 16-GRF-I of the drawdown and recovery curves resulting from pumping of a nearby municipal well is shown in figure 11. Each hydrograph was evaluated to determine the possible presence of pumping influences. Hydrographs of nested wells indicating simultaneous pumping influences were interpreted as interconnected (or moderately interconnected if water levels are different but have simultaneous responses to pumping, as might be the case for well nest 7-HRT-S/I/D example [fig. 9]). Similar pumping responses in multiple aquifer units indicate that the geologic layer separating the aquifer units is thin, permeable, and (or) discontinuous near the nested wells.

Temporal trends in water levels also can be identified from the hydrographs. Upward trends are indicated by an increase in the water levels (groundwater elevation), as the data are read from left to right. Conversely, downward trends are indicated by falling water levels (groundwater elevation) as the data are read from left to right. In groundwater analyses, meaningful, statistically significant trends can typically be determined only after a minimum of 10 years of water level monitoring (Taylor and Alley, 2001) to account for climatic influences. Because fewer than 10 years of monitoring data were available for this study, the statistical significance of the trend was not evaluated. Instead, a temporal trend was estimated by visual analysis of the hydrograph for each continuously monitored well for the period of record (2009-14). Hydrographs from the four periodically monitored NAWQA wells also were visually analyzed for trends.

The duration of data collection and the scale at which the observations are graphically plotted can play an important role in the ability to discern certain features on a hydrograph. For example, seasonal patterns can be observed only if enough time has passed to observe the repeated and predictable seasonal peaks and troughs associated with rising and falling water levels. Pumping influences can be observed in smaller time steps of approximately daily to weekly rise and fall in water levels.

Hydrographs were analyzed by progressively increasing the period from 1 day to the full period of record; seasonal water levels were compared from year to year. The hydrographs were viewed using the NWISWeb interface (http://waterdata.usgs.gov/nwis, "current data option") and the graphing tools of the USGS Groundwater Toolbox graphing tools software (Barlow and others, 2014). The NWISWeb interface was used to examine the continuous 15-minute data for effects of pumping. The Groundwater Toolbox only includes the daily data for each well in feet below land surface. The Groundwater Toolbox enables viewing and comparison of hydrographs from nested monitoring wells, rain gage, and streamgages (U.S. Geological Survey, 2017) to evaluate the rapidity and magnitude of response to precipitation, direction of vertical groundwater flow, and water-level responses to pumping (although, pumping influences are easier to detect using the 15-minute data).

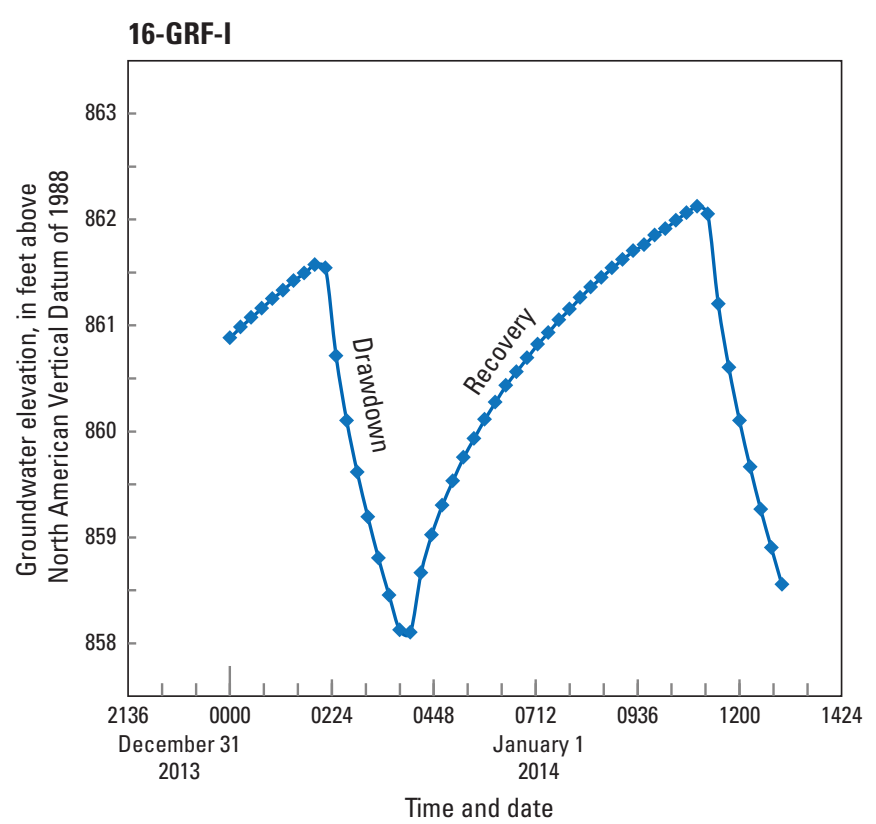

Figure 11. Pumping influences during a period of drawdown and recovery in response to withdrawal of groundwater followed by the cessation of pumping at monitoring well $16-\mathrm{GRF}-\mathrm{I}$, McHenry County, Illinois.

\section{Estimating Recharge from Precipitation}

Precipitation events can produce a "spike" in water levels that can be used to estimate the recharge to the groundwater system for a particular area around the monitoring well. The water-table fluctuation (WT fluctuation) method is based on the concept that water-level rises are due to recharge water from precipitation or interflow (flow between the unsaturated zone beneath the ground surface) reaching the water table, and can be applied only to unconfined aquifers (Healy and Cook, 2002). The method cannot be applied to wells with other influences such as pumping. The WT fluctuation method estimates recharge at a point location by multiplying the change in the water-table elevation by the specific yield of the aquifer (Healy and Cook, 2002; Delin and others, 2007). The RISE program was used to calculate the daily rise of water levels for the WT fluctuation method (Rutledge and Daniel, 1994; Rutledge, 1998; A.T. Rutledge, U.S. Geological Survey, written commun., 2005; Rutledge, 2014). The program calculates a rise in the water level from a continuous daily hydrograph by recording the amount (in units of length) by which the water level on each day exceeded that of the previous day. A decline in the water level from one day to the next is recorded as a zero rise for that day. The monthly sum of each rise was used as the total change in water level during the month. For the calculation of recharge, the specific yield was estimated for each well by correlation of the lithologic description of sediments at the well to tabulated values of 
specific yield for similar sediments presented in Johnson (1967) (table 6).

The selection of wells for analysis by the WT fluctuation method was based on the water levels (groundwater elevation) and rapid responses to precipitation (recharge). Nine hydrographs from wells open to unconfined aquifer units (14-RIL-S, 15-COR-S, 10-MAR-S, 9-MCH-S, 4-RCH-S, MHEN-08-01, 1-CHE-S, 11-SEN-I, and NW-6-45-9; fig. 1) and two hydrographs from wells open to semi-confined aquifer units (17-ALG-S and HEBR-08-02; fig. 1) were analyzed using this method. The two semi-confined wells were included in this analysis because the hydrographs for these wells indicated rapid responses to precipitation, demonstrating a close proximity to a recharge area or a discontinuity in the overlying confining (till) unit.

\section{Determination of Vertical Gradients}

The flow of water to or from deeper sand and gravel aquifers was classified as either recharge or discharge locations through the direction of the vertical gradients at nested wells. Recharge represents downward flow within or between aquifers. Discharge represents upward flow within or between aquifers and, in some cases, upward flow into surface-water bodies. The magnitude of the vertical hydraulic gradient can be used to infer the degree of aquifer confinement of the aquifer unit. Smaller vertical gradients indicate the confining unit is laterally discontinuous or thin. Large vertical gradients indicate the confining unit is laterally continuous and thick. The vertical direction of groundwater movement can be determined by the relative elevation of the water levels measured in two nested wells open to different aquifers-from higher water level to lower water level (assuming a simple one-dimensional vertical flow). The vertical hydraulic gradient is the change in water level at two nested wells divided by the vertical distance between the top or mid-point of the well screens (Fetter, 1988). The geometric mean groundwater elevation for each well was used to eliminate outliers (extreme high or low water levels) and to calculate the prevailing vertical gradient at each nested monitoring well location. Gradients can reverse, however, particularly at locations of discharge near small streams during seasonally dry periods.

\section{Water-Quality Sampling and Analysis}

Water-quality samples were collected from 41 wells in the MCGMN during June-November 2010 (two wells, MARN-10-03 and MARN-10-04, were not installed at the time of sampling). Five additional monitoring wells from the USGS NAWQA program also were included (fig. 1). The NAWQA wells are periodically monitored for water levels,
Table 6. Estimates of specific yield as described from lithologic descriptions for selected monitoring wells included in the water table fluctuation analysis for the calculation of recharge in McHenry County, Illinois.

[Locations of monitoring wells are shown in figure 1. Geologic description: From well logs (AECOM, 2009; Thomason and Keefer, 2013). Average specific yield: From Johnson (1967)]

\begin{tabular}{llc}
\hline $\begin{array}{c}\text { Monitoring } \\
\text { well }\end{array}$ & \multicolumn{1}{c}{\begin{tabular}{c}
\multicolumn{1}{c}{$\begin{array}{c}\text { Geologic } \\
\text { description }\end{array}$} \\
1-CHE-S
\end{tabular}} & $\begin{array}{c}\text { Average } \\
\text { specific yield }\end{array}$ \\
4-RCH-S & Fine silt and sand & 0.22 \\
9-MCH-S & Medium-to-coarse sand and gravel & 0.21 \\
10-MAR-S & Medium-to-coarse sand and gravel & 0.26 \\
11-SEN-I & Coarse gravel & 0.26 \\
14-RIL-S & Medium-to-coarse sand and gravel & 0.22 \\
15-COR-S & Gravel & 0.22 \\
17-ALG-S & Clay gravel & 0.22 \\
HEBR-08-02 & Medium-to-coarse sand and gravel & 0.26 \\
NW-6-45-9 & Fine-to-medium sand and gravel & 0.22 \\
MHEN-08-01 & Medium-to-coarse sand and gravel & 0.26 \\
\hline
\end{tabular}

and water-quality samples have been collected from these wells at either biannual or 5-year sampling intervals according to the NWIS (U.S. Geological Survey, 2017). Water-quality samples collected in 2010 from all 46 wells were analyzed for field parameters, major and minor ions, metals, and nutrients. Targeted shallow monitoring wells near urban or developed areas were selected for analyses of pesticides and volatile organic compounds (VOCs). Eight monitoring wells were sampled for analyses of pesticides and herbicides, trace elements, and dissolved gases, and 16 monitoring wells were selected for sampling of VOCs (table 7), 8 of which had a reduced list of 31 out of 86 VOCs.

\section{Sampling Procedures and Laboratory Analysis}

At each well site, the water level was measured using a calibrated electronic measuring tape and the level was compared with the most current transducer record. The transducer was removed for the duration of the sampling period. A Fultz ${ }^{\circledR}$ or Grundfos ${ }^{\circledR}$ submersible pump was slowly lowered into the well and the intake was placed about $2 \mathrm{ft}$ above the top of the screen. The pump discharge tubing was attached to a flow-through chamber of a multi-parameter sonde for the measurement of $\mathrm{pH}$, specific conductance, temperature, and dissolved oxygen (DO). Turbidity was measured separately from pump discharge with a $\mathrm{Hach}^{\circledR}$ field turbidity meter. 
Table 7. Field parameters, major and minor ions, metals, and nutrients analyzed for wells in McHenry County groundwater monitoring network, Illinois, 2010.

[Locations of monitoring wells are shown in figure 1. Abbreviations: NAWQA, National Water-Quality Assessment; NA, not available; X, analyzed for; -, not analyzed for]

\begin{tabular}{|c|c|c|c|c|c|c|c|c|c|c|}
\hline $\begin{array}{l}\text { Monitoring } \\
\text { well }\end{array}$ & $\begin{array}{c}\text { Field } \\
\text { parameters }\end{array}$ & $\begin{array}{c}\text { Major } \\
\text { ions }\end{array}$ & $\begin{array}{c}\text { Minor } \\
\text { ions }\end{array}$ & Metals & Nutrients & Pesticides & Herbicides & $\begin{array}{c}\text { Trace } \\
\text { elements }\end{array}$ & $\begin{array}{c}\text { Dissolved } \\
\text { gases }\end{array}$ & $\begin{array}{c}\text { Volatile } \\
\text { organic } \\
\text { compounds }\end{array}$ \\
\hline 14-RIL-S & $\mathrm{X}$ & $\mathrm{X}$ & $\mathrm{X}$ & $\mathrm{X}$ & $\mathrm{X}$ & - & - & - & - & $X^{1}$ \\
\hline HUNT-09-03 & $\mathrm{X}$ & $\mathrm{X}$ & $\mathrm{X}$ & $\mathrm{X}$ & $\mathrm{X}$ & - & - & - & - & - \\
\hline 16-GRF-I & $\mathrm{X}$ & $\mathrm{X}$ & $\mathrm{X}$ & $\mathrm{X}$ & $\mathrm{X}$ & - & - & - & - & - \\
\hline 16-GRF-D & $\mathrm{X}$ & $\mathrm{X}$ & $\mathrm{X}$ & $\mathrm{X}$ & $\mathrm{X}$ & - & - & - & - & - \\
\hline 17-ALG-S & $\mathrm{X}$ & $\mathrm{X}$ & $X$ & $\mathrm{X}$ & $\mathrm{X}$ & $\mathrm{X}$ & $\mathrm{X}$ & $\mathrm{X}$ & $\mathrm{X}$ & $\mathrm{X}$ \\
\hline 17-ALG-D & $\mathrm{X}$ & $\mathrm{X}$ & $\mathrm{X}$ & $\mathrm{X}$ & $\mathrm{X}$ & - & - & - & - & - \\
\hline MARS-09-01 & $\mathrm{X}$ & $\mathrm{X}$ & $\mathrm{X}$ & $\mathrm{X}$ & $\mathrm{X}$ & - & - & - & - & - \\
\hline 15-COR-S & $\mathrm{X}$ & $X$ & $\mathrm{X}$ & $X$ & $\mathrm{X}$ & - & - & - & - & $X^{1}$ \\
\hline 15-COR-I & $\mathrm{X}$ & $\mathrm{X}$ & $\mathrm{X}$ & $\mathrm{X}$ & $\mathrm{X}$ & - & - & - & - & - \\
\hline 15-COR-D & $\mathrm{X}$ & $\mathrm{X}$ & $\mathrm{X}$ & $\mathrm{X}$ & $\mathrm{X}$ & - & - & - & - & - \\
\hline 10-MAR-S & $\mathrm{X}$ & $\mathrm{X}$ & $\mathrm{X}$ & $\mathrm{X}$ & $\mathrm{X}$ & - & - & - & - & $\mathrm{X}^{1}$ \\
\hline WAUC-02-12 & $\mathrm{X}$ & $\mathrm{X}$ & $\mathrm{X}$ & $\mathrm{X}$ & $\mathrm{X}$ & - & - & - & - & - \\
\hline 11-SEN-I & $\mathrm{X}$ & $X$ & $X$ & $X$ & $\mathrm{X}$ & - & - & - & - & - \\
\hline 11-SEN-D & $\mathrm{X}$ & $\mathrm{X}$ & $\mathrm{X}$ & $\mathrm{X}$ & $\mathrm{X}$ & - & - & - & - & - \\
\hline 44N9E-20.7c & $\mathrm{X}$ & $\mathrm{X}$ & $X$ & $\mathrm{X}$ & $\mathrm{X}$ & $\mathrm{X}$ & $\mathrm{X}$ & $\mathrm{X}$ & $\mathrm{X}$ & $\mathrm{X}$ \\
\hline MARN-09-02 & $\mathrm{X}$ & $\mathrm{X}$ & $\mathrm{X}$ & $\mathrm{X}$ & $\mathrm{X}$ & - & - & - & - & - \\
\hline WOOD-08-01 & $\mathrm{X}$ & $\mathrm{X}$ & $\mathrm{X}$ & $\mathrm{X}$ & $\mathrm{X}$ & - & - & - & - & - \\
\hline 13-NUN-I & $\mathrm{X}$ & $\mathrm{X}$ & $\mathrm{X}$ & $\mathrm{X}$ & $\mathrm{X}$ & - & - & - & - & - \\
\hline 13-NUN-D & $\mathrm{X}$ & $\mathrm{X}$ & $\mathrm{X}$ & $\mathrm{X}$ & $\mathrm{X}$ & - & - & - & - & - \\
\hline WAUC-08-13 & $\mathrm{X}$ & $\mathrm{X}$ & $\mathrm{X}$ & $\mathrm{X}$ & $\mathrm{X}$ & - & - & - & - & - \\
\hline MHEN-08-01 & $\mathrm{X}$ & $\mathrm{X}$ & $\mathrm{X}$ & $\mathrm{X}$ & $\mathrm{X}$ & - & - & - & - & - \\
\hline MARN-09-01 & $\mathrm{X}$ & $\mathrm{X}$ & $\mathrm{X}$ & $\mathrm{X}$ & $\mathrm{X}$ & - & - & - & - & - \\
\hline 7-HRT-S & $\mathrm{X}$ & $\mathrm{X}$ & $\mathrm{X}$ & $\mathrm{X}$ & $\mathrm{X}$ & - & - & - & - & $\mathrm{X}^{1}$ \\
\hline 7-HRT-I & $\mathrm{X}$ & $\mathrm{X}$ & $\mathrm{X}$ & $\mathrm{X}$ & $\mathrm{X}$ & - & - & - & - & - \\
\hline 7-HRT-D & $\mathrm{X}$ & $\mathrm{X}$ & $\mathrm{X}$ & $\mathrm{X}$ & $\mathrm{X}$ & - & - & - & - & - \\
\hline 9-MCH-S & $\mathrm{X}$ & $\mathrm{X}$ & $\mathrm{X}$ & $\mathrm{X}$ & $\mathrm{X}$ & $\mathrm{X}$ & $\mathrm{X}$ & $\mathrm{X}$ & $\mathrm{X}$ & $\mathrm{X}$ \\
\hline 9-MCH-D & $\mathrm{X}$ & $\mathrm{X}$ & $\mathrm{X}$ & $\mathrm{X}$ & $\mathrm{X}$ & - & - & - & - & $\mathrm{X}^{1}$ \\
\hline 8-GRN-I & $\mathrm{X}$ & $\mathrm{X}$ & $\mathrm{X}$ & $\mathrm{X}$ & $\mathrm{X}$ & - & - & - & - & $\mathrm{X}^{1}$ \\
\hline 8-GRN-D & $\mathrm{X}$ & $\mathrm{X}$ & $\mathrm{X}$ & $\mathrm{X}$ & $\mathrm{X}$ & - & - & - & - & - \\
\hline HEBR-08-02 & $\mathrm{X}$ & $\mathrm{X}$ & $\mathrm{X}$ & $\mathrm{X}$ & $\mathrm{X}$ & - & - & - & - & - \\
\hline HARV-09-01 & $\mathrm{X}$ & $X$ & $\mathrm{X}$ & $\mathrm{X}$ & $\mathrm{X}$ & - & - & - & - & - \\
\hline NW-6-45-9 & $\mathrm{X}$ & $\mathrm{X}$ & $\mathrm{X}$ & $\mathrm{X}$ & $\mathrm{X}$ & - & - & - & - & - \\
\hline 1-CHE-S & $\mathrm{X}$ & $X$ & $\mathrm{X}$ & $\mathrm{X}$ & $\mathrm{X}$ & - & - & - & - & - \\
\hline 1-CHE-D & $\mathrm{X}$ & $\mathrm{X}$ & $\mathrm{X}$ & $\mathrm{X}$ & $\mathrm{X}$ & - & - & - & - & - \\
\hline 2-ALD-D & $\mathrm{X}$ & $\mathrm{X}$ & $\mathrm{X}$ & $\mathrm{X}$ & $\mathrm{X}$ & - & - & - & - & - \\
\hline HEBR-09-03 & $\mathrm{X}$ & $\mathrm{X}$ & $\mathrm{X}$ & $\mathrm{X}$ & $\mathrm{X}$ & - & - & - & - & - \\
\hline 4-RCH-S & $X$ & $\mathrm{X}$ & $\mathrm{X}$ & $X$ & $X$ & $\mathrm{X}$ & $\mathrm{X}$ & $\mathrm{X}$ & $\mathrm{X}$ & $\mathrm{X}$ \\
\hline 4-RCH-I & $\mathrm{X}$ & $\mathrm{X}$ & $\mathrm{X}$ & $\mathrm{X}$ & $\mathrm{X}$ & - & - & - & - & - \\
\hline 4-RCH-D & $\mathrm{X}$ & $\mathrm{X}$ & $\mathrm{X}$ & $\mathrm{X}$ & $\mathrm{X}$ & - & - & - & - & - \\
\hline HEBR-08-01 & $\mathrm{X}$ & $\mathrm{X}$ & $\mathrm{X}$ & $\mathrm{X}$ & $\mathrm{X}$ & - & - & - & - & - \\
\hline 3-HEB-I & $\mathrm{X}$ & $\mathrm{X}$ & $\mathrm{X}$ & $\mathrm{X}$ & $\mathrm{X}$ & - & - & - & - & $\mathrm{X}^{1}$ \\
\hline 3-HEB-D & $\mathrm{X}$ & $\mathrm{X}$ & $\mathrm{X}$ & $\mathrm{X}$ & $\mathrm{X}$ & & & & & $\mathrm{X}^{1}$ \\
\hline MARN-10-03 & NA & NA & NA & NA & NA & NA & NA & NA & NA & NA \\
\hline MARN-10-04 & NA & NA & NA & NA & NA & NA & NA & NA & NA & NA \\
\hline \multicolumn{11}{|c|}{ NAWOA Wells } \\
\hline $43 \mathrm{~N} 8 \mathrm{E}-8.2 \mathrm{c}$ & $\mathrm{X}$ & $\mathrm{X}$ & $\mathrm{X}$ & $\mathrm{X}$ & $\mathrm{X}$ & $\mathrm{X}$ & $\mathrm{X}$ & $\mathrm{X}$ & $\mathrm{X}$ & $\mathrm{X}$ \\
\hline 45N9E-7.6a & $\mathrm{X}$ & $X$ & $\mathrm{X}$ & $\mathrm{X}$ & $\mathrm{X}$ & $X$ & $\mathrm{X}$ & $X$ & $X$ & $\mathrm{X}$ \\
\hline $45 \mathrm{~N} 7 \mathrm{E}-32.4 \mathrm{~d}$ & $\mathrm{X}$ & $\mathrm{X}$ & $\mathrm{X}$ & $\mathrm{X}$ & $\mathrm{X}$ & $\mathrm{X}$ & $\mathrm{X}$ & $\mathrm{X}$ & $\mathrm{X}$ & $\mathrm{X}$ \\
\hline $43 \mathrm{~N} 8 \mathrm{E}-3.7 \mathrm{~d}$ & $\mathrm{X}$ & $\mathrm{X}$ & $\mathrm{X}$ & $\mathrm{X}$ & $\mathrm{X}$ & $\mathrm{X}$ & $\mathrm{X}$ & $\mathrm{X}$ & $\mathrm{X}$ & $X$ \\
\hline
\end{tabular}

${ }^{1}$ Reduced list (31 of 86) of VOCs analyzed. 
The height of the water column in the well and the inside diameter of the well were used to calculate the volume of water in the well. To obtain a representative sample, at least three well volumes of water were purged by pumping from the well at a rate of less than 0.15 gallon per minute ( $\mathrm{gal} / \mathrm{min})$, and a sample was collected after stabilization of $\mathrm{pH}$, specific conductance, temperature, DO, and turbidity values.

Water-quality samples were collected by following the methods described in the USGS National Field Manual for the Collection of Water-Quality Data (U.S. Geological Survey, variously dated). Alkalinity was determined by titration in the field using the inflection point method. Iron (II) and sulfide also were determined in the field using a $\mathrm{Hach}^{\circledR}$ spectrophotometer. Major and minor ions, trace elements, and nutrients were analyzed by the methods described in Fishman (1993), Fishman and Friedman (1989), and Garbarino and others (2006). Dissolved organic carbon was analyzed in eight monitoring wells by methods described in Brenton and Arnett (1993). Samples were analyzed for VOCs by purge and trap gas chromatography with quadrupole mass-spectrometric detection (Connor and others, 1998; NWQL Laboratory Schedule 2090). Pesticides and herbicides were analyzed according the laboratory methods described in Zaugg and others (1995) and Furlong and others (2001). Water-quality samples were shipped with appropriate sample preservation to the USGS National Water Quality Laboratory in Denver, Colorado, for analysis. Dissolved gases samples were shipped separately to the USGS Chlorofluorocarbon Laboratory in Reston, Virginia, for the analysis of dissolved gases (http:// water.usgs.gov/lab/dissolved-gas/).

\section{Statistical Analysis}

Maximum, minimum, median, and geometric mean statistics were calculated for the water levels and for the water-quality results, where detections were greater than the laboratory minimum reporting level (MRL). The MRL is the "less than" value reported when the constituent is either a nondetect or detected at a concentration less than the MRL (Childress and others, 1999). Estimated values were not included in the statistical calculations but were considered a trace detection if the detections were equal to or greater than the MRL.

The Wilcoxon rank-sum test (Helsel, 2005) was used to assess changes in the water-quality results between 1979 and 2010. The Wilcoxon rank sum test is a nonparametric statistical application that equalizes the skewness and variance of the two datasets. The hypothesized mean difference was set to zero (that is, the null hypothesis is no difference). A p-value less than 0.05 indicates that the null hypothesis is rejected and that there is a significant difference.

\section{Subsurface Oxidation-Reduction Conditions}

Chemical reactions in the subsurface induced by microbial populations control the concentrations of several naturally occurring constituents and their persistence in groundwater. Areas of redox conditions were determined from DO, major ions, sulfide, and nutrient results. These data were input to a model developed by Jurgens and others (2009), which assigns the predominant redox process to samples from terminal electron-accepting processes (TEAP) described in Chapelle and others (2003) and McMahon and Chapelle (2008), and is referred to as the Redox Assignment Model in this report. The default values for the thresholds for determining the redox state were applied in the model. General redox categories include the oxidation states denoted as oxic and suboxic, and the reduction states denoted as anoxic. Mixed state also is used to indicate a mixture of redox conditions. Redox processes are further defined for the types of reaction that are influencing oxic, reduced, or mixed states, such as oxidizing $\left(\mathrm{O}_{2}\right)$, mildly reducing (manganese, iron) to strongly reducing (sulfate reduction and [or] methanogenic). Information on the redox conditions of the groundwater at each location were used to understand the occurrence of constituents and areas of recharge.

The differences in concentration of select constituents were assessed for various oxidation-reduction (redox) conditions and for chemical differences among the sand and gravel aquifers. Estimated values were included if detection were equal to and (or) greater than the MRL. Less than values are concentrations that were not (reliably) detected above the MRL, and were halved and included in the input for the Redox Assignment Model.

\section{Chloride-Bromide Analysis}

Chloride-bromide (Cl-Br) analyses were used to determine the potential sources of the chloride $(\mathrm{Cl})$ concentrations detected in groundwater. The source mixing curves from the Northern glacial aquifer (Mullaney and others, 2009) were applied to the $\mathrm{Cl}$ concentration and $\mathrm{Cl}-\mathrm{Br}$ ratios for water-quality samples collected since 2010 , the periodic samples obtained for the specific conductance surrogate relation (described in the next section), and the results from the four water-quality samples collected from NAWQA wells since 2000 (wells 45N9E-7.6a, 45N7E-32.4d, 43 N8E-3.7d, and 43N8E-8.2c; fig. 1). Sample results with no detections for bromide were excluded from the analysis. The $\mathrm{Cl}$ concentration to $\mathrm{Cl}-\mathrm{Br}$ ratio for each water-quality sample was plotted relative to the source binary mixing curves to evaluate whether any of the water-quality samples represented various chloride sources and mixtures of dilute groundwater. The proximity of the sample ratio result to the source-mixing curve indicates a possibility that the sample result is from the potential source of the chloride. 


\section{Development of Specific Conductance as Surrogate for Chloride}

In 2011, four monitoring wells (14-RIL-S, 4-RCH-S, 9-MCH-S, 44N9E-20.7c; fig. 1) with previously detected elevated concentrations of chloride (greater than $195 \mathrm{mg} / \mathrm{L}$; U.S. Geological Survey, 2017) were equipped with pressure transducers with sensors capable of recording specific conductance at 15-minute intervals. A fifth monitoring well (10-MAR-S) was similarly equipped in 2013. The five wells recording specific conductance and water levels were sampled periodically by following the methods described in the National Field Manual for the Collection of Water-Quality Data (U.S. Geological Survey, variously dated), and surrogate relations were developed to estimate chloride concentrations. The sensor data were processed according to guidelines described in Wagner and others (2006). Specific conductance is related to the amount of dissolved solids or salts in the water and is directly proportional to the concentration of TDS, where high specific conductance indicates high TDS. Likewise, the chloride ion, particularly from salts, also is proportional to specific conductance. Specific conductance commonly is used as a surrogate for TDS, chlorides, and sulfates (Christensen and others, 2000; Brown and others, 2011), and can be used as a proxy for contaminants in the groundwater (Katz and others, 2011). To determine the relation between specific conductance and chloride concentration, water-quality samples were collected periodically during spring (period of thawing temperatures), winter, and summer to obtain a range of the potential chloride concentrations at each well. Ten to 11 water-quality samples from each well were collected between January 2009 and June 2015 and analyzed for chlorides. The January 2009 water-quality samples are sourced from AECOM (2009). A fifth monitoring well (10-MAR-S) was similarly equipped in 2013 and designated as a shallow (20 ft below land surface) background well; seven waterquality samples were collected from this well between 2009 and 2015. A sixth monitoring well (4-RCH-I) also was included as a deep ( $98 \mathrm{ft}$ below land surface) background well. Well 4-RCH-I was not equipped with a sensor to record specific conductance; however, it was sampled periodically for analysis of chloride concentrations and seven samples were collected between 2009 and 2015.

These data were used to develop a correlation between specific conductance and chloride concentration for each well using a linear regression analysis described by Christensen and others (2000) and Helsel and Hirsch (2002). These regression equations were used to compute chloride concentrations in each specific well (within a specified error range) using continuously measured specific conductance values.

\section{Quality Assurance and Quality Control}

A quality-assurance plan for water-quality sample constituents analyzed in this study consisted of blanks and replicates (major and minor ions, metals, nutrients, VOCs, and pesticides) collected in the field and laboratory to evaluate and control bias in analytical results. One spike was also collected for VOCs and pesticides. Two equipment blanks (from sampling pumps after cleaning between sample sites) and two replicates were collected during the 2010 sampling period (4 percent). Copper and cobalt were detected in the equipment blanks equal to or greater than the environmental concentrations; thus, these constituents in the water-quality samples were subsequently removed from statistical analysis. No VOCs were detected in the equipment blanks. The relative percent difference, calculated as the difference in the environmental and replicate concentration divided by the mean of the two concentrations, were less than 10 percent. One equipment blank was collected during the periodic sampling for chloride and results indicate that chloride and other constituents were all less than their respective reporting limits.

\section{Hydrogeology}

Natural influences such as precipitation, seasonal and annual changes in water levels due to climatic variables (including weather, barometric pressure, and evapotranspiration), and geology can determine the hydrogeologic setting. Anthropogenic influences can be identified from water-level changes because of pumping. Results of the decision matrix analysis of groundwater levels and their responses to precipitation, seasonal and annual variation, barometric pressure, geologic influences, and pumping influences are shown in table 8 .

\section{Precipitation and Water-Level Responses}

A groundwater system typically has a natural source of inflow (replenishment) from precipitation at land surface that is recharged to the groundwater system. The magnitude of the water-level response following a precipitation event is the result of numerous variables such as soil-column depth, saturation, specific yield, and geology (Shaver and Ripley, 1989). This response to precipitation can be seen in a hydrograph, and the magnitude of the water-level rise can be qualitatively categorized as rapid (sharp), moderate (rounded), or muted (negligible) (fig. 8). Summary results for precipitation responses are included in table 8 . Some wells had muted responses to precipitation that had been subdued by pumping influences (see section, "Pumping Influences"). Water-level responses to precipitation for each well in the MCGMN are shown in figure 12. 
Table 8. Degree of aquifer confinement and interconnections from the analysis of water levels, responses to precipitation, barometric pressure, thickness of overlying clay, pumping influences, vertical gradient, and trends for wells in the McHenry County groundwater monitoring well network, Illinois.

[Locations of monitoring wells are shown in figure 1. Water level above top of sand unit: WT, water table. Abbreviations: ft, foot; N, no; NA, not applicable because of pumping influences; Y, yes]

\begin{tabular}{|c|c|c|c|c|c|c|c|c|c|c|c|c|}
\hline $\begin{array}{l}\text { Monitoring } \\
\text { well }\end{array}$ & $\begin{array}{c}\text { Aquifer } \\
\text { unit }\end{array}$ & Pumping & $\begin{array}{l}\text { Precipitation } \\
\text { response } \\
\text { rate }\end{array}$ & $\begin{array}{c}\text { Barometric } \\
\text { pressure } \\
\text { response }\end{array}$ & $\begin{array}{l}\text { Overlying } \\
\text { clay } \\
\text { thickness } \\
\text { (ft) }\end{array}$ & $\begin{array}{l}\text { Water level } \\
\text { above top of } \\
\text { sand unit }\end{array}$ & $\begin{array}{l}\text { Water level } \\
\text { different from } \\
\text { other wells } \\
\text { in nest }\end{array}$ & $\begin{array}{l}\text { Pumping } \\
\text { response from } \\
\text { other wells } \\
\text { in nest }\end{array}$ & Interconnection & $\begin{array}{c}\text { Confinement } \\
\text { status }\end{array}$ & $\begin{array}{l}\text { Vertical } \\
\text { gradient }\end{array}$ & Trend \\
\hline 14-RIL-S & $\begin{array}{l}\text { Haeger-Beverly } \\
\text { Unit }\end{array}$ & $\mathrm{N}$ & Rapid & $\mathrm{N}$ & None & WT & NA & NA & NA & Unconfined & NA & Stable \\
\hline HUNT-09-03 & Ashmore Unit & $\mathrm{N}$ & Rapid & Y (slight) & 69 & $\mathrm{Y}$ & NA & NA & NA & Semi-confined & NA & Stable \\
\hline 16-GRF-I & Ashmore Unit & $\mathrm{Y}$ & Muted & $\mathrm{N}$ & 55 & $\mathrm{Y}$ & Y (slight) & $\mathrm{Y}$ & Moderate & Semi-confined & Down & Decrease \\
\hline 16-GRF-D & $\begin{array}{l}\text { Lower Glasford } \\
\text { Sand Unit }\end{array}$ & $\mathrm{Y}$ & Muted & $\mathrm{Y}$ & 35 & $\mathrm{Y}$ & $\mathrm{Y}$ (slight) & Y (slight) & Moderate & Semi-confined & Down & Stable \\
\hline 17-ALG-S & $\begin{array}{l}\text { Yorkville- } \\
\text { Batestown Unit }\end{array}$ & $\mathrm{N}$ & Rapid & Y & 18.5 & $\mathrm{Y}$ & $\mathrm{Y}$ & NA & Weak & Semi-confined & Down & Stable \\
\hline 17-ALG-D & $\begin{array}{l}\text { Shallow Bedrock } \\
\text { Aquifer }\end{array}$ & $\mathrm{N}$ & Muted & $\mathrm{Y}$ & 70.5 & $\mathrm{Y}$ & $\mathrm{Y}$ & NA & Weak & Confined & Down & Increase \\
\hline MARS-09-01 & $\begin{array}{l}\text { Upper Glasford } \\
\text { Sand Unit }\end{array}$ & $\mathrm{Y}$ & Muted & $\mathrm{Y}$ & 179 & $\mathrm{Y}$ & NA & NA & NA & Confined & NA & Stable \\
\hline 15-COR-S & $\begin{array}{l}\text { Haeger-Beverly } \\
\text { Unit }\end{array}$ & $\mathrm{N}$ & Rapid & $\mathrm{N}$ & 31 & WT & $\mathrm{N}$ & NA & Strong & Unconfined & Down & Stable \\
\hline 15-COR-I & Ashmore Unit & $\mathrm{N}$ & Rapid & $\mathrm{N}$ & None & WT & $\mathrm{N}$ & NA & $\begin{array}{l}\text { Same aquifer } \\
\text { unit }\end{array}$ & Unconfined & Up & Stable \\
\hline 15-COR-D & Ashmore Unit & $\mathrm{N}$ & Rapid & $\mathrm{N}$ & None & WT & $\mathrm{N}$ & NA & $\begin{array}{l}\text { Same aquifer } \\
\text { unit }\end{array}$ & Unconfined & Up & Stable \\
\hline 10-MAR-S & $\begin{array}{l}\text { Haeger-Beverly } \\
\text { Unit }\end{array}$ & $\mathrm{N}$ & Rapid & $\mathrm{N}$ & None & WT & NA & NA & NA & Unconfined & NA & Stable \\
\hline WAUC-02-12 & $\begin{array}{l}\text { Lower Glasford } \\
\text { Sand Unit }\end{array}$ & $\mathrm{Y}$ & NA & $\mathrm{Y}$ & 54 & $\mathrm{Y}$ & NA & NA & NA & Confined & NA & Stable \\
\hline 11-SEN-I & Ashmore Unit & $\mathrm{N}$ & Rapid & $\mathrm{N}$ & 4 & WT & $\mathrm{N}$ & NA & Strong & Unconfined & Down & Stable \\
\hline 11-SEN-D & $\begin{array}{l}\text { Lower Glasford } \\
\text { Sand Unit }\end{array}$ & $\mathrm{N}$ & Rapid & $\mathrm{N}$ & 5 & WT & $\mathrm{N}$ & NA & Strong & Unconfined & Down & Stable \\
\hline 44N9E-20.7c & $\begin{array}{l}\text { Haeger-Beverly } \\
\text { Unit }\end{array}$ & $\mathrm{Y}$ & NA & $\mathrm{N}$ & 4 & WT & NA & NA & NA & Unconfined & NA & NA \\
\hline MARN-09-02 & $\begin{array}{l}\text { Upper Glasford } \\
\text { Sand Unit }\end{array}$ & $\mathrm{Y}$ & Moderate & $\mathrm{Y}$ & 14 & $\mathrm{Y}$ & $\mathrm{N}$ & $\mathrm{Y}$ & $\begin{array}{l}\text { Same aquifer } \\
\text { unit }\end{array}$ & Semi-confined & Up & Stable \\
\hline MARN-10-04 & $\begin{array}{l}\text { Upper Glasford } \\
\text { Sand Unit }\end{array}$ & $\mathrm{Y}$ & Muted & Y (slight) & 7 & $\mathrm{Y}$ & $\mathrm{N}$ & $\mathrm{Y}$ & $\begin{array}{l}\text { Same aquifer } \\
\text { unit }\end{array}$ & Semi-confined & Up & Stable \\
\hline MARN-10-03 & $\begin{array}{l}\text { Lower Glasford } \\
\text { Sand Unit }\end{array}$ & $\mathrm{N}$ & Muted & $\mathrm{Y}$ & 23 & $\mathrm{Y}$ & $\mathrm{Y}$ & NA & Weak & Confined & Up & Stable \\
\hline WOOD-08-01 & Ashmore Unit & $\mathrm{N}$ & Muted & $\mathrm{Y}$ & 165 & $\mathrm{Y}$ & NA & NA & NA & Confined & NA & Stable \\
\hline
\end{tabular}


Table 8. Degree of aquifer confinement and interconnections from the analysis of water levels, responses to precipitation, barometric pressure, thickness of overlying clay, pumping influences, vertical gradient, and trends for wells in the McHenry County groundwater monitoring well network, Illinois.-Continued

\begin{tabular}{|c|c|c|c|c|c|c|c|c|c|c|c|c|}
\hline $\begin{array}{l}\text { Monitoring } \\
\text { well }\end{array}$ & $\begin{array}{l}\text { Aquifer } \\
\text { unit }\end{array}$ & Pumping & $\begin{array}{l}\text { Precipitation } \\
\text { response } \\
\text { rate }\end{array}$ & $\begin{array}{l}\text { Barometric } \\
\text { pressure } \\
\text { response }\end{array}$ & $\begin{array}{l}\text { Overlying } \\
\text { clay } \\
\text { thickness } \\
\text { (ft) }\end{array}$ & $\begin{array}{l}\text { Water level } \\
\text { above top of } \\
\text { sand unit }\end{array}$ & $\begin{array}{l}\text { Water level } \\
\text { different from } \\
\text { other wells } \\
\text { in nest }\end{array}$ & $\begin{array}{l}\text { Pumping } \\
\text { response from } \\
\text { other wells } \\
\text { in nest }\end{array}$ & Interconnection & $\begin{array}{c}\text { Confinement } \\
\text { status }\end{array}$ & $\begin{array}{l}\text { Vertical } \\
\text { gradient }\end{array}$ & Trend \\
\hline 13-NUN-I & $\begin{array}{l}\text { Yorkville- } \\
\text { Batestown Unit }\end{array}$ & $\mathrm{Y}$ & NA & $\mathrm{N}$ & 70.5 & $\mathrm{Y}$ & $\mathrm{N}$ & $\mathrm{Y}$ & Strong & Semi-confined & $\mathrm{Up}$ & Stable \\
\hline 13-NUN-D & $\begin{array}{l}\text { Shallow Bedrock } \\
\text { Aquifer and } \\
\text { Lower Glasford } \\
\text { Sand Unit }\end{array}$ & $\mathrm{Y}$ & NA & $\mathrm{N}$ & 22 & $\mathrm{Y}$ & $\mathrm{N}$ & $\mathrm{Y}$ & Strong & Semi-confined & Up & Stable \\
\hline WAUC-08-13 & $\begin{array}{l}\text { Haeger-Beverly } \\
\text { Unit }\end{array}$ & $\mathrm{Y}$ & Muted & $\mathrm{Y}$ & None & WT & NA & NA & NA & Unconfined & NA & Decrease \\
\hline MHEN-08-01 & $\begin{array}{l}\text { Haeger-Beverly } \\
\text { Unit }\end{array}$ & $\mathrm{N}$ & Muted & $\mathrm{N}$ & None & WT & NA & NA & NA & Unconfined & NA & Stable \\
\hline MARN-09-01 & $\begin{array}{l}\text { Upper Glasford } \\
\text { Sand Unit }\end{array}$ & $\mathrm{N}$ & Moderate & $\mathrm{N}$ & None & WT & NA & NA & NA & Unconfined & NA & Stable \\
\hline 7-HRT-S & $\begin{array}{l}\text { Haeger-Beverly } \\
\text { Unit }\end{array}$ & $\mathrm{Y}$ & Muted & $\mathrm{Y}$ & 41 & $\mathrm{Y}$ & $\mathrm{N}$ & Y (slight) & Strong & Semi-confined & Down & Stable \\
\hline 7-HRT-I & $\begin{array}{l}\text { Upper Glasford } \\
\text { Sand Unit }\end{array}$ & $\mathrm{Y}$ & Muted & $\mathrm{Y}$ & 18 & $\mathrm{Y}$ & $\mathrm{N}$ & Y (slight) & Strong & Semi-confined & Down & Stable \\
\hline 7-HRT-D & $\begin{array}{l}\text { Shallow Bedrock } \\
\text { Aquifer and } \\
\text { Lower Glasford } \\
\text { Sand Unit }\end{array}$ & $\mathrm{Y}$ & Muted & $\mathrm{Y}$ & 30 & $\mathrm{Y}$ & $\mathrm{Y}$ & $\mathrm{Y}$ & Moderate & Semi-confined & Down & Stable \\
\hline 9-MCH-S & $\begin{array}{l}\text { Haeger-Beverly } \\
\text { Unit }\end{array}$ & $\mathrm{N}$ & Rapid & $\mathrm{N}$ & None & WT & $\mathrm{Y}$ & $\mathrm{N}$ & Weak & Unconfined & Down & Stable \\
\hline 9-MCH-D & Ashmore Unit & $\mathrm{Y}$ & Muted & $\mathrm{Y}$ & 117 & $\mathrm{Y}$ & $\mathrm{Y}$ & $\mathrm{N}$ & Weak & Confined & Down & Stable \\
\hline 8-GRN-I & $\begin{array}{l}\text { Haeger-Beverly } \\
\text { Unit }\end{array}$ & $\mathrm{Y}$ & Moderate & $\mathrm{Y}$ & 9.8 & $\mathrm{Y}$ & $\mathrm{Y}$ & $\mathrm{N}$ & Weak & Semi-confined & Down & Decrease \\
\hline 8-GRN-D & $\begin{array}{l}\text { Lower Glasford } \\
\text { Sand Unit }\end{array}$ & $\mathrm{Y}$ & Muted & $\mathrm{Y}$ & 27 & $\mathrm{Y}$ & $\mathrm{Y}$ & $\mathrm{N}$ & Weak & Confined & Down & Decrease \\
\hline HEBR-08-02 & $\begin{array}{l}\text { Haeger-Beverly } \\
\text { Unit }\end{array}$ & $\mathrm{N}$ & Rapid & $\mathrm{N}$ & 7.5 & $\mathrm{Y}$ & NA & NA & NA & Semi-confined & NA & Stable \\
\hline HARV-09-01 & Ashmore Unit & $\mathrm{N}$ & Moderate & $\mathrm{Y}$ & 79 & $\mathrm{Y}$ & NA & NA & NA & Semi-confined & NA & Stable \\
\hline NW-6-45-9 & $\begin{array}{l}\text { Haeger-Beverly } \\
\text { Unit }\end{array}$ & $\mathrm{N}$ & Muted & $\mathrm{Y}$ & 28 & WT & NA & NA & NA & Unconfined & NA & Decrease \\
\hline 1-CHE-S & Ashmore Unit & $\mathrm{N}$ & Rapid & Y (slight) & None & WT & $\mathrm{N}$ & NA & Strong & Unconfined & Up & Stable \\
\hline 1-CHE-D & $\begin{array}{l}\text { Shallow Bedrock } \\
\text { Aquifer }\end{array}$ & $\mathrm{N}$ & Rapid & $\mathrm{Y}$ (slight) & 49 & $\mathrm{Y}$ & $\mathrm{N}$ & NA & Strong & Semi-confined & Up & Stable \\
\hline 2-ALD-D & $\begin{array}{l}\text { Lower Glasford } \\
\text { Sand Unit }\end{array}$ & $\mathrm{N}$ & Muted & $\mathrm{Y}$ & 328 & $\mathrm{Y}$ & NA & NA & NA & Confined & NA & Stable \\
\hline
\end{tabular}


Table 8. Degree of aquifer confinement and interconnections from the analysis of water levels, responses to precipitation, barometric pressure, thickness of overlying clay, pumping influences, vertical gradient, and trends for wells in the McHenry County groundwater monitoring well network, Illinois.-Continued

\begin{tabular}{|c|c|c|c|c|c|c|c|c|c|c|c|c|}
\hline $\begin{array}{l}\text { Monitoring } \\
\text { well }\end{array}$ & $\begin{array}{l}\text { Aquifer } \\
\text { unit }\end{array}$ & Pumping & $\begin{array}{l}\text { Precipitation } \\
\text { response } \\
\text { rate }\end{array}$ & $\begin{array}{l}\text { Barometric } \\
\text { pressure } \\
\text { response }\end{array}$ & $\begin{array}{l}\text { Overlying } \\
\text { clay } \\
\text { thickness } \\
\text { (ft) }\end{array}$ & $\begin{array}{l}\text { Water level } \\
\text { above top of } \\
\text { sand unit }\end{array}$ & $\begin{array}{l}\text { Water level } \\
\text { different from } \\
\text { other wells } \\
\text { in nest }\end{array}$ & $\begin{array}{l}\text { Pumping } \\
\text { response from } \\
\text { other wells } \\
\text { in nest }\end{array}$ & Interconnection & $\begin{array}{c}\text { Confinement } \\
\text { status }\end{array}$ & $\begin{array}{l}\text { Vertical } \\
\text { gradient }\end{array}$ & Trend \\
\hline HEBR-09-03 & Ashmore Unit & $\mathrm{Y}$ & Muted & $\mathrm{Y}$ & 97 & $\mathrm{Y}$ & NA & NA & NA & Confined & NA & Stable \\
\hline 4-RCH-S & $\begin{array}{l}\text { Haeger-Beverly } \\
\text { Unit }\end{array}$ & $\mathrm{N}$ & Rapid & $\mathrm{N}$ & None & WT & $\mathrm{Y}$ & NA & Weak & Unconfined & Down & Stable \\
\hline 4-RCH-I & $\begin{array}{l}\text { Upper Glasford } \\
\text { Sand Unit }\end{array}$ & $\mathrm{Y}$ & Muted & $\mathrm{Y}$ & 76 & $\mathrm{Y}$ & $\mathrm{N}$ & $\mathrm{Y}$ & Moderate & Semi-confined & $\mathrm{Up}$ & Stable \\
\hline 4-RCH-D & $\begin{array}{l}\text { Shallow Bedrock } \\
\text { Aquifer and } \\
\text { Lower Glasford } \\
\text { Sand Unit }\end{array}$ & $\mathrm{Y}$ & Muted & $\mathrm{Y}$ & 75 & $\mathrm{Y}$ & $\mathrm{N}$ & $\mathrm{Y}$ & Moderate & Semi-confined & Up & Stable \\
\hline HEBR-08-01 & Ashmore Unit & $\mathrm{Y}$ & Moderate & $\mathrm{Y}$ & 59 & $\mathrm{Y}$ & NA & NA & NA & Confined & NA & Stable \\
\hline 3-HEB-I & Ashmore Unit & $\mathrm{N}$ & Moderate & Y & 16.5 & $\mathrm{Y}$ & $\mathrm{N}$ & NA & Strong & Semi-confined & $\mathrm{Up}$ & Decrease \\
\hline 3-HEB-D & $\begin{array}{l}\text { Upper Glasford } \\
\text { Sand Unit }\end{array}$ & $\mathrm{N}$ & Moderate & Y (slight) & 4 & $\mathrm{Y}$ & $\mathrm{N}$ & NA & Strong & Semi-confined & $\mathrm{Up}$ & Decrease \\
\hline
\end{tabular}




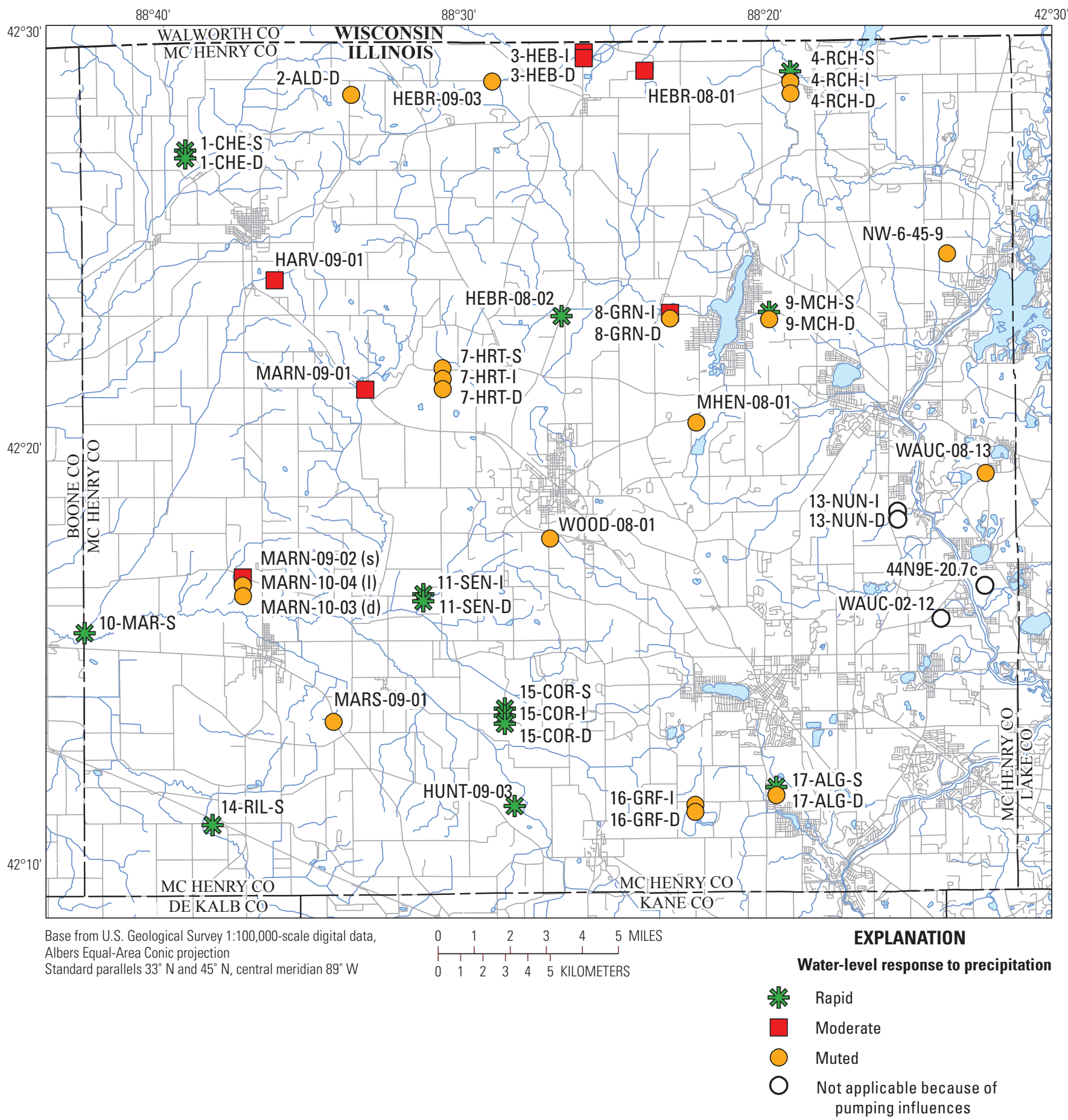

Figure 12. Monitoring wells with rapid, moderate, or muted water-level responses to precipitation in the McHenry County groundwater monitoring network, Illinois. 
Hydrographs with rapid responses to precipitation were primarily in the shallowest (less than $55 \mathrm{ft}$ below land surface) monitoring wells; however, some water levels in the deep (greater than $75 \mathrm{ft}$ below land surface) monitoring wells (HEBR-08-02, 11-SEN-I and -D, 1-CHE-D, 15-COR-I and -D, and HUNT-09-03; fig. 12) also had rapid responses (fig. 13). Many of these deep wells had rapid responses to precipitation despite having clay sequences with a range in thickness of 7.5-69 ft. These layers probably are discontinuous near these locations. Two deep wells at nested wells, 11-SEN-D (well depth $153 \mathrm{ft}$ below land surface) and 1-CHE-D (well depth $110 \mathrm{ft}$ below land surface), have rapid responses to precipitation similar to their shallow counterparts (11-SEN-I and 1-CHE-S, well depths $75 \mathrm{ft}$ and $40 \mathrm{ft}$, respectively). The rapid water-level responses to precipitation at these well nests may indicate a nearby discontinuity that allows the deeper aquifer unit to receive recharge rapidly and similarly to the shallow counterpart.

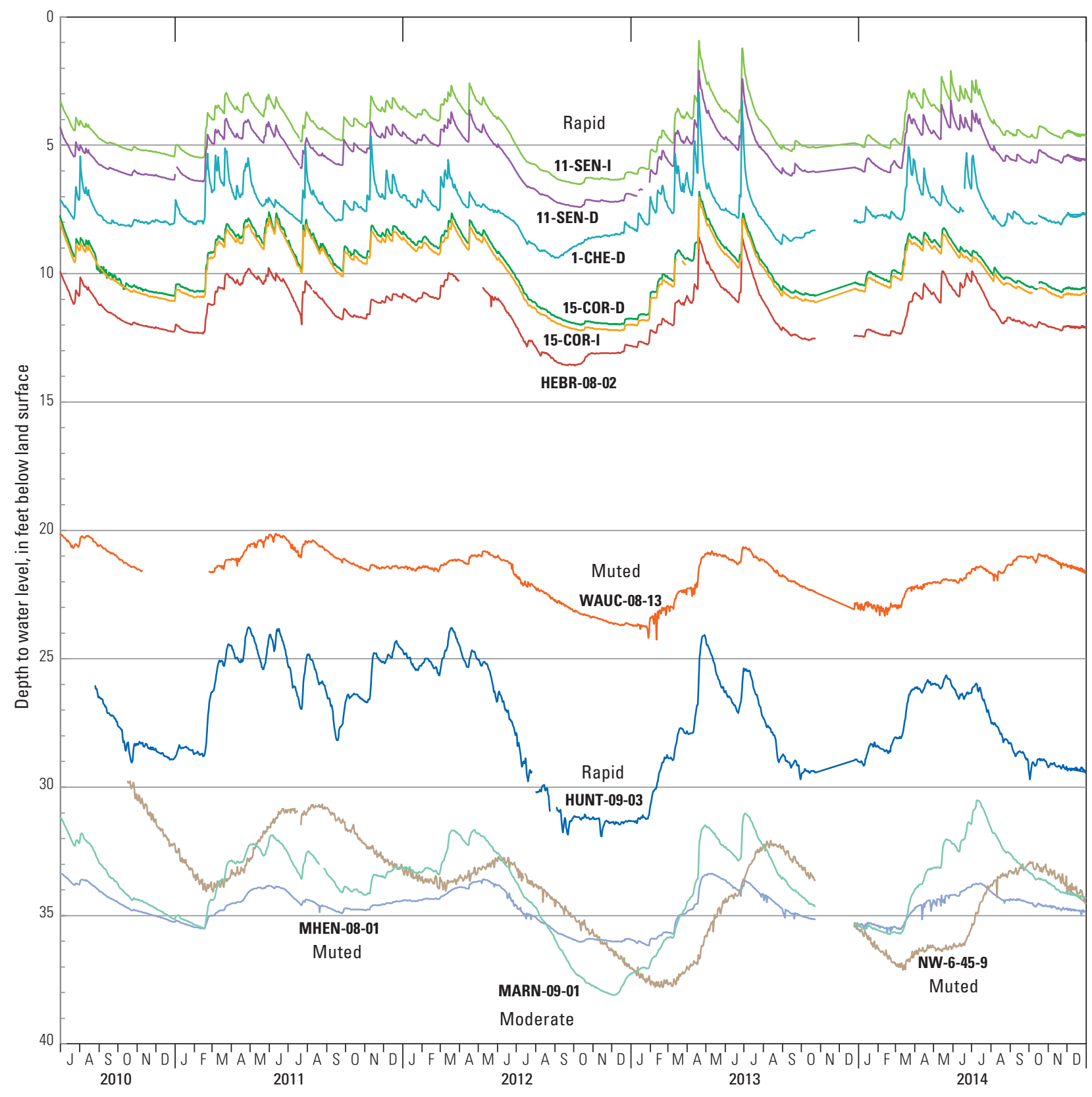

Figure 13. Water-levels in deep (well depth greater than 75 feet below land surface) monitoring wells with rapid (sharp), moderate (rounded), or muted (negligible) responses to precipitation in the McHenry County groundwater monitoring network, Illinois. 
Hydrographs with moderate responses were observed in several wells (table 8) where well logs showed several thin layers of clays, or only one thick layer of clay with interbedded sand and gravel lenses. In one well, however, (MARN-09-01) moderate responses to precipitation were observed (fig. 13); this well is $100 \mathrm{ft}$ below land surface and has no clay layers noted in the well log. Precipitation seems to recharge the aquifer relatively quickly at this location, as noted by the rounded peaks in the hydrograph.

Hydrographs (fig. 13) show muted responses to precipitation in two wells (WAUC-08-13 and MHEN-08-01), but no clay layer and thick sand and gravel sequences were noted in the well log. The depth to water at these wells typically is about $33 \mathrm{ft}$ below land surface - much greater than at the other locations with rapid responses to periods of precipitation where the depth to water usually is less than $10 \mathrm{ft}$. The muted response to precipitation at these wells presumably is due to the greater distance that the infiltrating precipitation needs to travel to reach the water table. The remaining monitoring wells with muted responses to precipitation were wells with one or more thick (greater than $30 \mathrm{ft}$ ) clay and or silty clay materials overlying the well screen. At three locations, the responses to precipitation could not be determined at four wells because of additional water-level influences, like pumping (NA, table 8).

\section{Seasonal and Annual Variation in Water Levels}

Seasonal differences in duration and magnitude of precipitation and evapotranspiration influence the timing of recharge to the aquifer. Results of the typical period when water levels reached their highest (peak) and lowest (trough) for each monitoring well hydrograph are shown in table 9 . The troughs at WAUC-02-12 were estimated to be the result of excessive pumping. Groundwater recharge from winter snowmelt, coupled with elevated amounts of the early- to late-spring precipitation and limited evapotranspiration, caused groundwater levels to rise. Water levels in McHenry County typically peaked between March or early June in 95 percent of the monitoring wells. Two percent of monitoring wells (1 of 43; NW-6-45-9) had water levels that peaked in summer, and nearly 5 percent ( 2 of 43; 17-ALG-D and WOOD-08-01), had water levels that peaked in winter. The delay in peak recharge likely is because of an increased length of time for the precipitation to recharge the deeper aquifer units. The hydrographs for these wells also showed muted responses to precipitation.

Evapotranspiration - precipitation returned to the air through evaporation and uptake by plants - is typically most prevalent during the summer months; thus, water levels tend to decline in the summer as less precipitation infiltrates to

Table 9. Highest and lowest annual water levels by season for wells in the McHenry County groundwater monitoring network, Illinois, 2009-14.

[Locations of monitoring wells are shown in figure 1. Season: Spring, summer, autumn, winter. Peak: Lowest depth to water. Trough: Greatest depth to water]

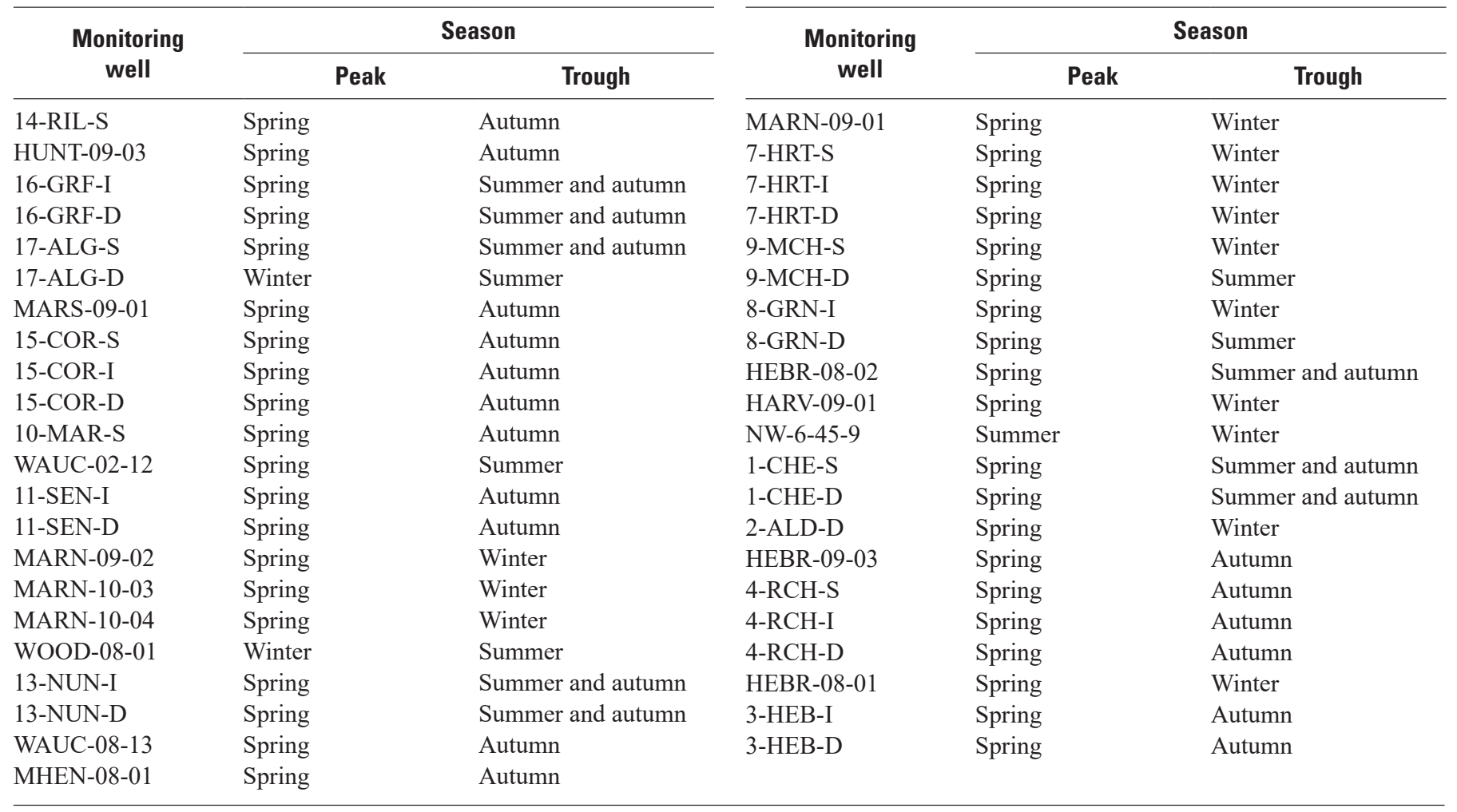


the water table. Water levels typically were at their lowest in September or October (autumn) for 40 percent (17 of 42) of monitoring wells, when the least amount of precipitation typically occurs and evapotranspiration is ongoing. Thirty-one percent (13 of 42) of monitoring wells had water levels at the lowest during winter months of November-January, when the ground typically is frozen and limited precipitation recharges the aquifers. Another 31 percent (13 of 42) of monitoring wells had lowest water levels during summer. Of the wells with the lowest water levels reached during summer, 62 percent also had declining water levels during autumn so that they had two periods of declining water levels. This may be because of the added influences of pumping or withdrawal by nearby center-pivots or supply wells (see section, "Pumping Influences"). Precipitation and recharge did not exceed the drainage or withdrawal rate at these wells.

The change in water level throughout the year indicates the change in the amount of water stored in the aquifer. The change in aquifer storage can be used to determine the variation in volume of groundwater that is available throughout the year. The change in water level also can be used to determine the percentage of water recharged to the aquifer that is stored in the groundwater system at the end of a given year.

Annual variations for the period of record included two extremes in weather variability. The fourth wettest (2009) on record for Illinois followed the second wettest (2008) on record since 1895, according to the ISWS (Angel, 2009). In 2009, the 50.27 in. of precipitation for the State was 28 percent greater than the historical average (1895-2009) of 39.2 in. (Angel, 2009). A severe to extreme drought started in winter 2011 and continued throughout 2012 (Angel, 2012). The total precipitation for the State during the drought was 20.84 in., 47 percent less than the historical average (Illinois Department of Natural Resources and Illinois Environmental Protection Agency, 2013). Additionally, snowfall is a primary contributor to recharge in the Midwest, as the seasonal spring melt replenishes the aquifers when evapotranspiration is at the lowest level (Edwards and others, 2015). Snowfall from 2011 to 2014 ranged from 24.7 to 57.1 in. at Rockford, Illinois, according to the National Weather Service (2014). Snowfall in 2012 was 24 percent less than the historical average (1905-2015) of 32.6 in., whereas snowfall in 2013 was 75 percent greater and snowfall in 2014 was 29 percent greater than the historical average (National Weather Service, 2015).

The average annual water level at each monitoring well was calculated and, from those averages, the median water level (depth to water) was calculated. Three rain gages, (05548280-RG, 05548105-RG, and HEBRON-RG; U.S. Geological Survey, 2017), associated, in part, with select streamgage stations in McHenry County, collect precipitation data through a calibrated tipping-bucket, that logs the data every 15 -minutes and sends it to NWIS. Table 10 shows
Table 10. Precipitation and median water levels recorded in selected wells in the McHenry County groundwater monitoring network, Illinois, 2009-14.

[Precipitation recorded by rain gages $05548280-\mathrm{RG}, 05548105-\mathrm{RG}$, and HEBRON-RG. Illinois State Geological Survey wells were excluded because transducers were not installed until August 2009. Abbreviations: ft, foot; in. inch]

\begin{tabular}{ccc}
\hline Year & $\begin{array}{c}\text { Total } \\
\text { precipitation } \\
\text { (in.) }\end{array}$ & $\begin{array}{c}\text { Median depth to } \\
\text { water level } \\
\text { (ft below land surface) }\end{array}$ \\
\hline 2009 & 36.68 & 9.18 \\
2010 & 28.01 & 10.31 \\
2011 & 30.71 & 10.88 \\
2012 & 22.20 & 12.53 \\
2013 & 40.72 & 12.02 \\
2014 & 31.51 & 11.66 \\
\hline
\end{tabular}

comparisons of the total precipitation recorded by the rain gages to the median water levels each year for only the McHenry County monitoring wells (fig. 1) of the MCGMN. The ISGS monitoring wells were excluded because pressure transducers were not installed until August 2009. Water levels reached their peak in 2009, following 2 years of record precipitation. The 2009 peak water levels from the MCGMN wells (fig. 1) were used to assess the timing of the peak water level to understand the potential for recharge at the various well locations. Peak water levels (smallest values) recorded in 2009 are shown in table 11. Peak water levels occurred primarily in May with water levels peaking in March at four wells and in February in one well (17-ALG-D). Water levels in wells that peak earlier recharge more rapidly than in other wells. Water levels slowest to peak were at well nests 15-COR-S/I/D, 11-SEN-I/D, 9-MCH-S, and 3-HEB-I/D (fig. 1). The delay in peak recharge at these locations may be related to the replenishing of the total capacity of aquifer storage as previously unsaturated zones became saturated. Water levels at some deep wells (16-GRF-D, 9-MCH-D, and 1-CHE-D) had peaked before their shallow counterparts in the well nests. This could indicate that monitoring wells completed in the deeper aquifer units have an overlying confining layer and the water level response is from a recharge area at a distal upland location from the nested wells.

In 2012, water levels throughout the aquifer reached their lowest levels for the study period (2009-14), with water levels in wells in the eastern part of the county having a greater magnitude of groundwater decline, partly due to the larger population in the area and greater volume of withdrawals to satisfy demand. Water levels in the wells generally began declining after they peaked from spring recharge in 2012. The decline (drawdown) in water level during the 2012 drought period for each monitoring well is shown in table 12 and is compared to the drawdowns in 2010. 
Table 11. Peak water levels recorded in selected wells in the McHenry County groundwater monitoring network, Illinois, 2009.

[Locations of monitoring wells are shown in figure 1. Illinois State Geological Survey monitoring wells were excluded because transducers and real-time equipment were not installed until August 2009. NA, not available]

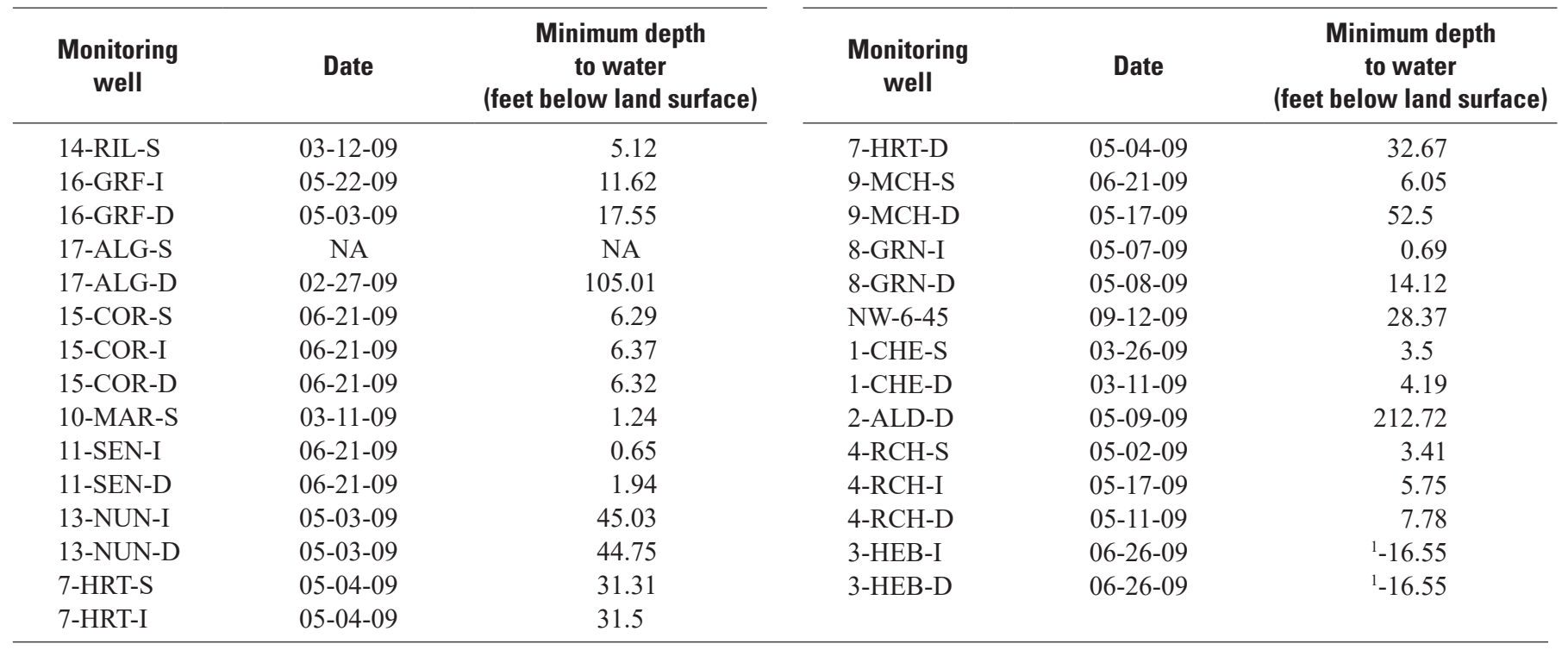

${ }^{1}$ Flowing artesian conditions. The water level rises above the land surface naturally due to confined pressurized conditions.

Table 12. Maximum drawdown (lowest water level) during the 2012 drought conditions and 2010 normal precipitation conditions measured in wells in the McHenry County groundwater monitoring network, Illinois.

[Locations of monitoring wells are shown in figure 1. Abbreviations: $\mathrm{ft}$, foot; NA, not applicable]

\begin{tabular}{|c|c|c|c|c|c|}
\hline \multirow{2}{*}{$\begin{array}{c}\text { Monitoring } \\
\text { well }\end{array}$} & \multicolumn{2}{|c|}{ Annual variation-maximum drawdown (ft) } & \multirow{2}{*}{$\begin{array}{c}\text { Monitoring } \\
\text { well }\end{array}$} & \multicolumn{2}{|c|}{ Annual variation-maximum drawdown (ft } \\
\hline & 2012 drought & $\begin{array}{l}2010 \text { normal } \\
\text { precipitation }\end{array}$ & & 2012 drought & $\begin{array}{l}2010 \text { normal } \\
\text { precipitation }\end{array}$ \\
\hline 14-RIL-S & -4.32 & -3.68 & MHEN-08-01 & -2.44 & -1.89 \\
\hline HUNT-09-03 & -8.13 & -4.94 & MARN-09-01 & -6.44 & -4.15 \\
\hline 16-GRF-I & -13.49 & -6.01 & 7-HRT-S & -8.97 & -6.68 \\
\hline 16-GRF-D & -8.77 & -5.19 & 7-HRT-I & -8.87 & -6.74 \\
\hline 17-ALG-S & -8.21 & -1.19 & 7-HRT-D & -10.41 & -9.13 \\
\hline 17-ALG-D & -26.97 & -14.72 & 9-MCH-S & -5.85 & -4.39 \\
\hline MARS-09-01 & -10.09 & -8.08 & 9-MCH-D & -9.98 & -5.09 \\
\hline 15-COR-S & -4.37 & -3.87 & 8-GRN-I & -3.99 & -4.59 \\
\hline 15-COR-I & -4.31 & -3.86 & 8-GRN-D & -6.26 & -2.85 \\
\hline 15-COR-D & -4.35 & -3.87 & HEBR-08-02 & -3.61 & -2.88 \\
\hline 10-MAR-S & -4.64 & -3.71 & HARV-09-01 & -5.06 & -3.42 \\
\hline WAUC-02-12 & -31.39 & -22.04 & NW-6-45-9 & -4.34 & -2.54 \\
\hline 11-SEN-I & -3.93 & -3.72 & 1-CHE-S & -3.96 & -3.74 \\
\hline 11-SEN-D & -3.78 & -3.53 & 1-CHE-D & -3.83 & -3.43 \\
\hline 44N9E-20.7c & NA & NA & 2-ALD-D & -6.92 & -4.87 \\
\hline MARN-09-02 & -5.91 & -4.91 & HEBR-09-03 & -6.2 & -4.87 \\
\hline MARN-10-04 & -5.78 & NA & 4-RCH-S & -5.76 & -5.85 \\
\hline MARN-10-03 & -6.69 & NA & 4-RCH-I & -7.58 & -6.99 \\
\hline WOOD-08-01 & -5.89 & -3.97 & 4-RCH-D & -4.17 & -3.64 \\
\hline 13-NUN-I & -4.49 & -3.52 & HEBR-08-01 & -4.17 & -3.64 \\
\hline 13-NUN-D & -4.48 & -3.32 & 3-HEB-I & -3.49 & -3.02 \\
\hline WAUC-08-13 & -2.89 & -1.59 & 3-HEB-D & -3.48 & -3.01 \\
\hline
\end{tabular}


Precipitation (28.01 in.) recorded by the USGS rain gages (fig. 1; U.S. Geological Survey, 2017) in 2010 were below the precipitation values recorded by the Rockford Weather Station (36.92 in.; National Weather Service, 2010) and the Illinois State Water Survey Climate rain gage in DeKalb (35.15 in.; Illinois State Water Survey, 2016) (fig. 1). Precipitation for 2010 was within the normal (typical) amount of 36.24 in. In 2012, water levels at monitoring well WAUC-02-12 declined about $30 \mathrm{ft}$, more than any other well, and water levels in well 17-ALG-D declined about $27 \mathrm{ft}$. By comparison, in 2010, water levels at WAUC-02-12 declined about $22 \mathrm{ft}$, and water levels in 17-ALG-D, declined about $15 \mathrm{ft}$. Water levels declined by about 7-13 ft at wells MARS-09-01, HUNT-09-03, 16-GRF-D, 10-MAR-S, 7-HRT-S/I/D, 9-MCH-D, and 4-RCH-I. Drought not only decreases the water levels regionally because of diminished recharge, but demand for water (withdrawals for irrigation, lawn watering, and swimming pools) increases. Thus, localized effects of the drought on water levels are further enhanced. Water levels in monitoring well 10-MAR-S (fig. 1) declined about $5 \mathrm{ft}$ during the 2012 drought. Prolonged droughts can greatly reduce aquifer storage and limit water availability from an aquifer. Additionally, depending on the water level in relation to the riverbeds of streams (and if they are hydraulically connected), groundwater discharge into streams may be reduced during prolonged drought periods.

The drought that started in the winter of 2011 and continued throughout 2012 greatly reduced the amount of snowfall for winter 2011-12 and limited the amount of recharge typically received to the aquifer from spring melt (Angel, 2012). Substantially larger decreases in water levels were measured during the drought year in numerous wells. The wells with the greatest decline (greater than $10 \mathrm{ft}$ ) in water levels generally were those in the deeper aquifers, such as the upper and lower Glasford Sand Unit aquifers and the shallow bedrock aquifer. Changes in climate are another consideration for long-term groundwater resource management planning. Drought periods are projected to increase in frequency and duration (Chicago Metropolitan Agency for Planning, 2013).

\section{Geologic Influences}

The physical characteristics of coarse- and fine-grained deposits, their thickness, depths, and degree of interconnection, influence the aquifer properties in each hydrogeological setting. Aquifer properties such as permeability (hydraulic conductivity), storage, specific yield, transmissivity, and water level (hydraulic head) determine the water availability and water quality of an aquifer.

Permeability is a function of hydraulic conductivity and is a measure of the ease with which water passes through the material (deposits) (Freeze and Cherry, 1979). Coarse-grained deposits, such as sands and gravels, allow water to pass through easily. Sands and gravels can have high permeability and function as aquifers capable of transmitting larger volumes of water. Fine-grained deposits, such as silts and clays, have lower permeability than sand or gravel and therefore transmit less water at a lower rate of transmission. As a result, these deposits generally function as confining or semi-confining units, restricting the movement of water. The sands and gravels occur in glacial sediments as either thick, continuous deposits, or as isolated lenses between fine-grained deposits. The size, thickness, and geographic extent of a sand and gravel deposits and the degree of interconnection of water within the deposits through intervening tills controls the degree of isolation of any sand and gravel body. This strongly influences the unconfined, semi-confined, or confined condition of the aquifer, and therefore, the aquifer type. Water levels (hydraulic head) respond differently in each hydrogeological setting and are used to determine the aquifer type.

\section{Unconfined, Semi-Confined, and Confined Aquifers}

Unconfined aquifers in McHenry County are located in areas where sand and gravel deposits are at or near land surface, where overlying low-permeability deposits are thin or absent, and where the water level is below the top of the sands and gravels that makes up the aquifer. At locations where wells were considered to tap unconfined aquifers, clay layers were thin or not present, the water level was at or near the water table, responses to precipitation were rapid or moderate, and responses to barometric pressures were not present.

Semi-confined aquifers are common in glacial aquifer systems (Kasenow, 2010). Semi-confined sand and gravel aquifers are overlain by thin discontinuous layers of low-permeability materials that restrict the vertical movement of water into and out of the aquifer but does not completely isolate the aquifer from the surrounding hydrologic system. Hydrologic connectivity occurs primarily where the confining layer is absent. Water levels in a semi-confined aquifer can be above the elevation of the top of the aquifer, and may be similar to the water levels in overlying aquifers. Water-level response in a semi-confined aquifer to precipitation and other influences may be similar to those of overlying aquifers at a given location. Semi-confined aquifers were determined based on lithologies of layers of sand and gravel with interbedded clay layers; thickness ranged from 4 to $79 \mathrm{ft}$. Semi-confined aquifers also were determined from water levels that rise above the top of the aquifer unit or are similar to the water level in the shallow or deep nested well, slight responses to barometric pressure, rapid or moderate responses to precipitation, and pumping influences similar to other nested wells. 
Confined aquifers are overlain by continuous layers of thick low-permeability materials that restrict the vertical movement of water into and out of the aquifer and substantially isolate the aquifer from the overlying hydrologic unit. Water levels in confined aquifers often are substantially different than those in overlying or underlying aquifers at a well nest, and respond differently (if at all) to short-term and seasonal changes in recharge, as well as pumping. Confined aquifers were determined from well logs that showed overlying clays of thicknesses ranging from 23 to $328 \mathrm{ft}$, water levels above the top of the aquifer unit, inverse responses to barometric pressure, and muted responses to precipitation.

The distribution of the hydrogeologic setting varies widely for each aquifer unit; therefore, an aquifer unit can have unconfined, semi-confined, or confined conditions depending on the location (fig. 14; table 8). Monitoring wells determined to represent unconfined aquifer conditions occurred primarily within the Haeger-Beverly, Yorkville-Batestown, and in some cases, the Ashmore units. Semi-confined conditions occurred in all aquifer units at monitoring well locations noted in figure 14 . The confined aquifer units are primarily the Ashmore, Upper Glasford Sand, Lower Glasford Sand, and Shallow Bedrock aquifer units at the locations identified in figure 14.

\section{Degree of Interconnection}

Strongly interconnected conditions occur at unconfined aquifers to deeper semi-confined aquifers at wells 15-COR-S,-I, and -D, 11-SEN-I and -D, 7-HRT-S and -I, and 1-CHE-S and -D (fig. 14, table 8). Moderate to weak interconnections were noted at 16-GRF-I and -D, 17-ALG-S and -D, MARN-09-02 and MARN-10-03, 7-HRT-D, 9-MCH-S and -D, 8-GRN-I and -D, 4-RCH-S, -I, and -D (table 8). Most of these wells are open to deeper units that are either semi-confined or confined aquifer units, except one well (4-RCH-S) that is located in a thin (less than $5 \mathrm{ft}$ ) unconfined aquifer unit.

\section{Pumping Influences}

Water availability in regards to pumping (withdrawal) needs in unconfined, semi-confined, and confined aquifers can vary substantially. Water levels respond to pumping differently for each aquifer type. Pumping water from an unconfined aquifer removes water from the pore spaces of the saturated sediment. The water table lowers in response and forms a cone of depression generally centered on the location of pumping (Barlow and Moench, 1999), and could potentially reduce the amount of water available to a nearby supply well. Depending on the degree of interconnection of a semi-confined aquifer (semi-confined aquifer is connected to overlying unconfined aquifer), the amount of water available to a nearby supply well may be increased and result in a smaller cone of depression.
In a confined aquifer, pumping decreases water level and subsequently, the pressure, and therefore can result in a deeper and more expansive cone of depression (Alley and others, 1999). The difference in water availability and water level responses to pumping in unconfined versus confined aquifers is primarily related to substantial differences in the volume of water released from storage (storage coefficient) (Alley and others, 1999).

Pumping influences were observed in 43 percent (19 of 44) of the monitoring wells. Monitoring wells with hydrograph features that indicate a response to nearby pumping are identified in figure 15. Most of the monitoring wells show pumping influences in the deep aquifer units of the Ashmore Unit, Upper Glasford Sand Unit, and Lower Glasford Sand Units (table 8). Two wells show pumping influences in the shallow aquifer units: Haeger-Beverly (44N9E-20.7c) and Yorkville-Batestown Sand Unit (13-NUN-I). Some wells showing pumping influences (HEBR-08-01, MARN-09-02, MARN-10-04, MARS-09-01) may be near center-pivot irrigation wells shown in figure 2. Monitoring well, WAUC-02-12, does not show a nearby supply well; however, a golf course is located a little more than $0.25 \mathrm{mi}$ away and the pumping signatures at this well show drawdown and recovery cycles that begin in early spring and end in autumn of each year.

Monitoring wells with pumping influences also may be used to infer the relative extent of the cone of depression and possibly the total area of influence from the municipal supply wells in an area. Water managers can make a judgment about what level of drawdown would be undesirable to locals and can make informed decisions on pumping rates and duration. Such pumping adjustments could help reduce the drawdown in the confined aquifers while maintaining an adequate supply. In addition to protecting the water supply to nearby residential homes, the surface waters can be protected from adversely decreased flows because of over-pumping from supply wells.

\section{Estimated Recharge at Groundwater Monitoring Sites}

Recharge occurs largely in areas where the aquifer is exposed at the surface, in areas where the aquifer is overlain by permeable deposits, or exclusively from seepage through the confining layers to the aquifer. Unconfined aquifers can rapidly receive substantial volumes of recharge from precipitation compared to confined aquifers. This propensity to receive recharge also makes them vulnerable to contaminants entering the groundwater from surface activities. Recharge to a semi-confined aquifer may also be comparatively substantial but also makes it vulnerable to contaminants from the overlying unconfined aquifer. In contrast, confined aquifers are hydraulically isolated from recharge and are therefore less vulnerable to contaminants, but are susceptible to over-extraction of the available water. 


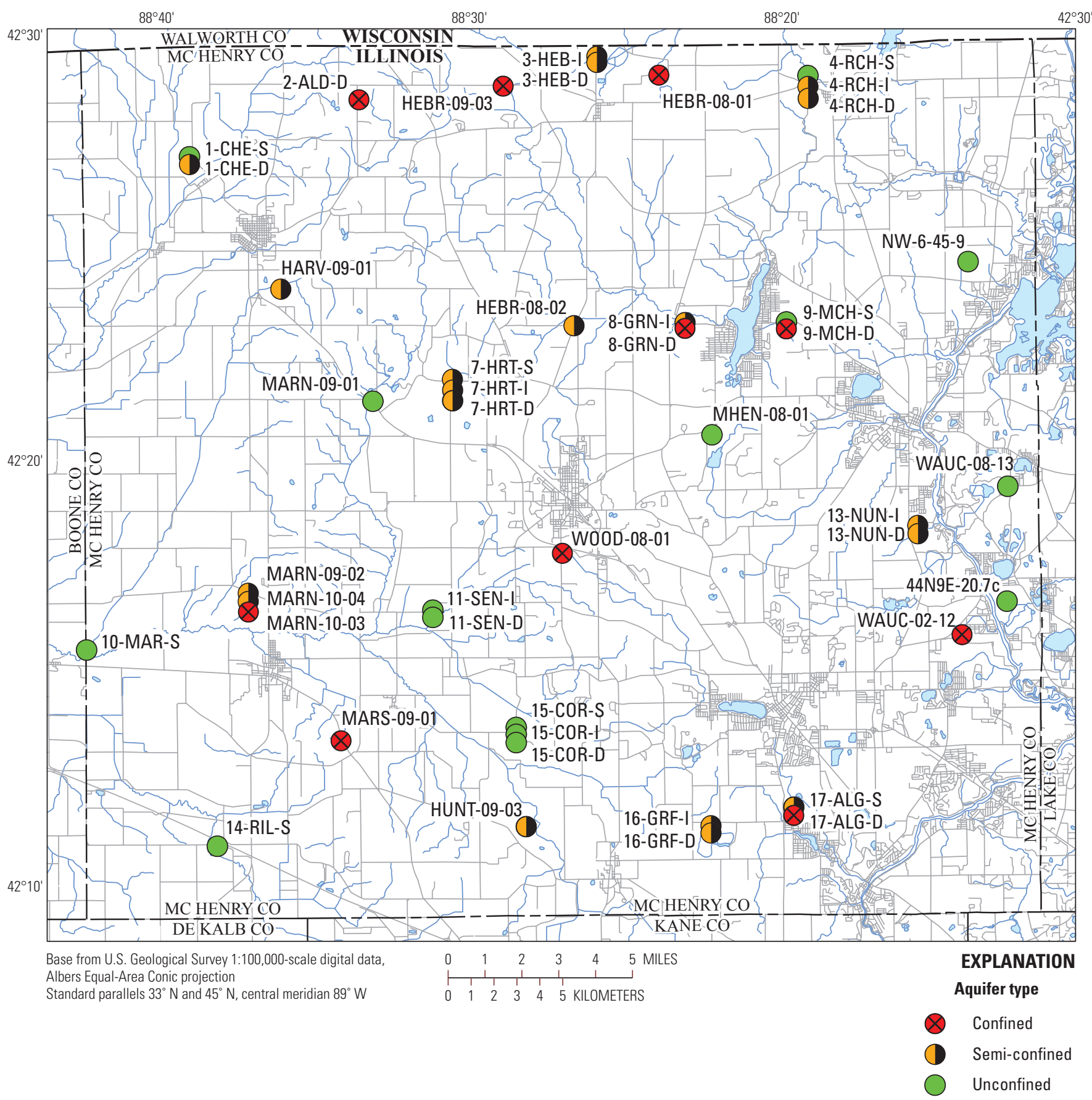

Figure 14. Degree of aquifer confinement (aquifer type) as determined from water levels and geology reported in well logs for the McHenry County groundwater monitoring network, Illinois. 


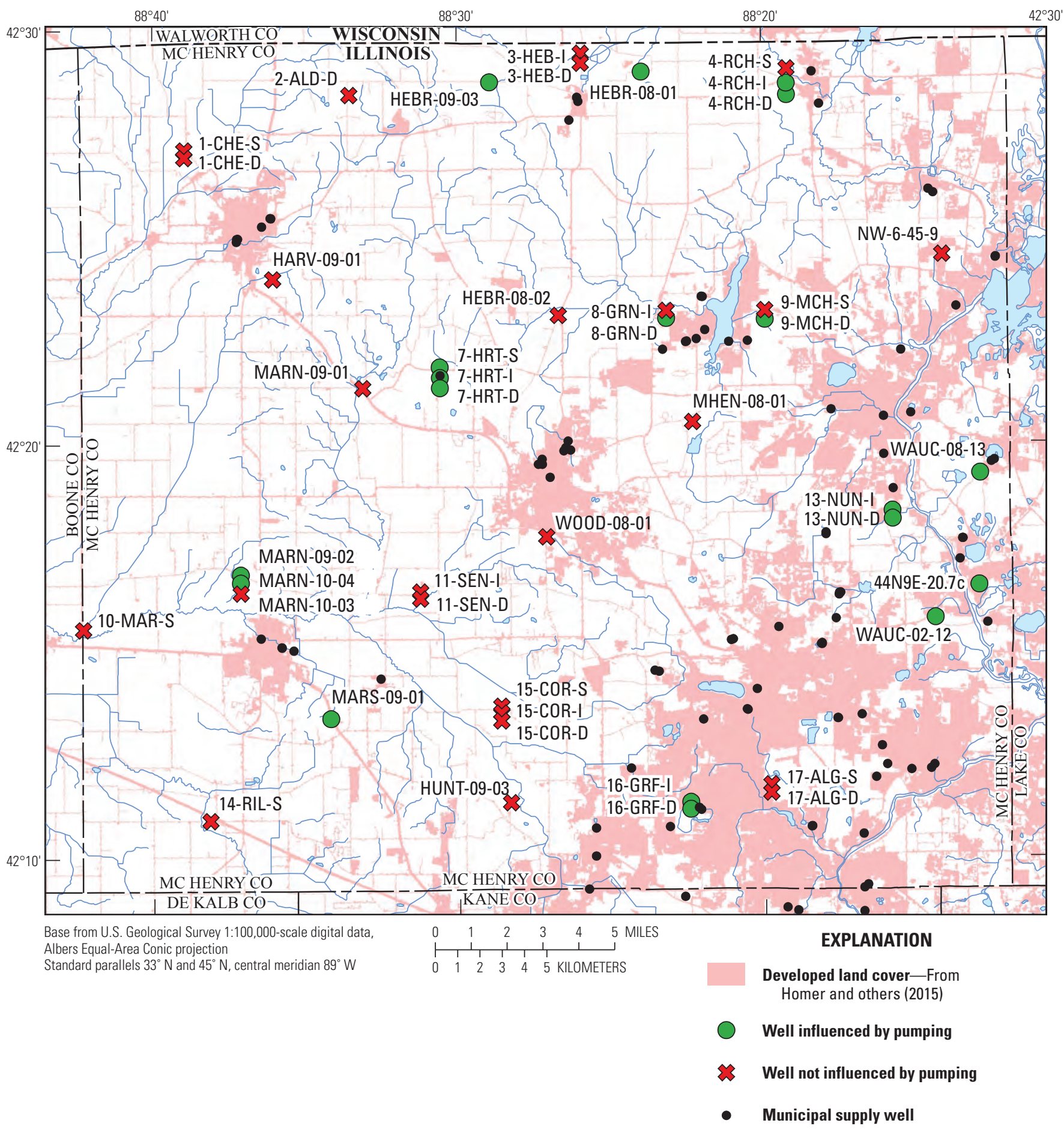

Figure 15. Monitoring wells with and without pumping influences in the McHenry County groundwater monitoring network, Illinois. (Municipal supply well data provided by Illinois Environmental Protection Agency, written commun., May 29, 2015.) 
Annual recharge amounts estimated using the WT fluctuation method (Healy and Cook, 2002) are provided in table 13 and range from 1.17 to 4.60 inches per year. Estimates were calculated for 11 monitoring well sites where an unconfined or semi-confined aquifer unit is tapped. The spatial distribution of average annual recharge is shown in figure 16. Overall, the annual averages were less than the recharge rate used in the groundwater model by Meyer and others (2013) (about 7 inches per year [in/yr]). The specific yield values assigned to the wells (table 6) included in the recharge estimates reflected the fine-grained materials noted in the well logs. In contrast, the model by Meyer and others (2013) did not apply lower recharge values in areas of low permeability. A previous study estimated recharge to be 127,000 gallons per day per square mile $\left[(\mathrm{gal} / \mathrm{d}) / \mathrm{mi}^{2}\right]$ (Walton, 1965), which converts to $1.96 \mathrm{in} / \mathrm{yr}$, for the Woodstock, Illinois, area. Walton (1965) also estimated recharge for the Kishwaukee River Basin upstream of Belvidere, Illinois, which includes parts of western McHenry County. A range of recharge was estimated at $3.88 \mathrm{in} / \mathrm{yr}\left(97,000\left[(\mathrm{gal} / \mathrm{d}) / \mathrm{mi}^{2}\right]\right)$ for below-normal precipitation years to as much as $16 \mathrm{in} / \mathrm{yr}$ $\left(401,000\left[(\mathrm{gal} / \mathrm{d}) / \mathrm{mi}^{2}\right]\right)$ for above-normal precipitation years. Recharge estimates from this study were low but within the range of recharge values from previous investigations. Delin and others (2007) reported that the RISE approach ignores the hydrograph recession that occurs in the absence of recharge. Therefore, the RISE method is inherently biased to provide lower estimates of recharge values. It is also possible that the specific yield range applied in this report $(0.21-0.26)$ to account for the lower permeable material described in the well logs may be too low and actual values may be closer to the higher specific yield range between $0.25-0.30$ presented in Johnson (1967).

\section{Vertical Gradients}

Vertical gradients were used to determine the flow direction to or from deeper parts of the sand and gravel aquifers. Nested monitoring wells were used to determine the predominant flow path to assess areas of recharge (downward) or discharge (upward). At monitoring well nest 1-CHE-S and 1-CHE-D, the average flow direction is upward, indicating that the bedrock aquifer is discharging into the nearby stream(s). At monitoring well nests 16-GRF-I, -D; 11-SEN-I, -D; 7-HRT-S, -I, -D; 9-MCH-S, -D; and 8-GRN-I, -D, the average direction of groundwater flow is downward, indicating that these are areas where recharge to the groundwater system generally is occurring (table 8). The term "generally" is applied because the use of geometric mean vertical gradient overlooks possible changes from recharge to discharge (or discharge to recharge) related to changing
Table 13. Recharge and annual average recharge estimated using the water-table fluctuation method for selected monitoring wells in the McHenry County groundwater monitoring network, Illinois, 2011-14.

[Locations of monitoring wells are shown in figure 1. All recharge values are in inches per year]

\begin{tabular}{|c|c|c|c|c|c|}
\hline \multirow{2}{*}{$\begin{array}{l}\text { Monitoring } \\
\text { well }\end{array}$} & \multicolumn{4}{|c|}{ Recharge } & \multirow{2}{*}{$\begin{array}{l}\text { Average annual } \\
\text { recharge }\end{array}$} \\
\hline & 2011 & 2012 & 2013 & 2014 & \\
\hline 14-RIL-S & 3.23 & 0.95 & 2.78 & 1.22 & 2.04 \\
\hline 15-COR-S & 3.22 & 0.89 & 1.78 & 1.84 & 1.93 \\
\hline 10-MAR-S & 2.89 & 2.46 & 1.99 & 2.11 & 2.36 \\
\hline 9-MCH-S & 1.68 & 1.20 & 2.23 & 2.40 & 1.88 \\
\hline HEBR-08-02 & 3.08 & 1.21 & 2.64 & 1.98 & 2.23 \\
\hline 4-RCH-S & 3.91 & 2.56 & 2.77 & 3.35 & 3.15 \\
\hline 11-SEN-I & 1.60 & 1.12 & 3.15 & 0.91 & 1.70 \\
\hline 1-CHE-S & 2.81 & 1.74 & 2.92 & 1.61 & 2.27 \\
\hline NW-6-45-9 & 2.68 & 2.52 & 3.38 & 3.08 & 2.91 \\
\hline MHEN-08-01 & 0.76 & 0.61 & 1.61 & 1.71 & 1.17 \\
\hline 17-ALG-S & 4.57 & 3.41 & 5.65 & 4.79 & 4.60 \\
\hline Average & & & & & 2.39 \\
\hline
\end{tabular}

conditions (pumping, or seasonal and annual variations). These possibilities are not addressed in this assessment.

General recharge occurs where no low-permeable layer is at the surface that limits infiltration. The aquifer sensitivity map created by Curry and others (1997, pl. 1) has been modified in figure 17 to include the McHenry County groundwater monitoring network and vertical flow directions (gradients). The aquifer sensitivity codes A1-B4 indicate the greatest potential for contamination because little to no fine-grained (clay) materials are near land surface (fig. 17). Areas with aquifer sensitivity codes $\mathrm{C} 1-\mathrm{F}$ indicate between 20 and $100 \mathrm{ft}$ (or more) of clay overlying aquifers and indicate moderate to low potential for aquifer contamination. Additional details about aquifer sensitivity codes are available in Curry and others (1997). Recharge occurs at the locations of many of the shallow monitoring wells identified as the water-table wells. In much of the eastern one-half of the county and along the Fox River valley (fig. 3), surficial sand and gravel deposits are greater than $50 \mathrm{ft}$ thick and within $5 \mathrm{ft}$ of land surface (Curry and others, 1997). Greater amounts of recharge generally occur in these areas as shown by the WT fluctuation estimates (fig. 16). The deposits in these areas predominantly are alluvial outwash with little till; these sandy deposits allow for generally rapid infiltration of precipitation into the groundwater. Therefore, the aquifer sensitivity at many of these locations is classified as moderate to high potential for aquifer contamination. 


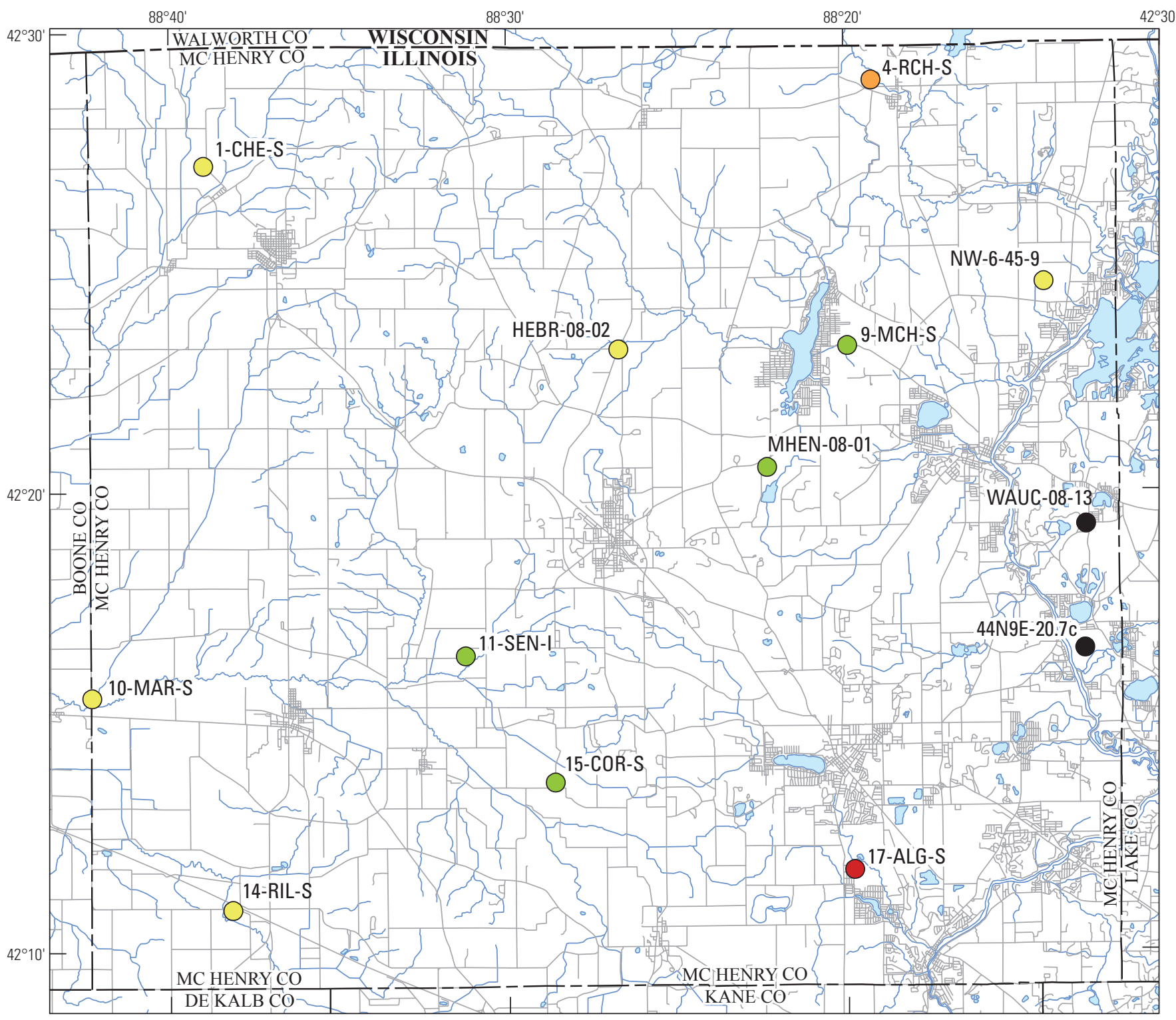

Base from U.S. Geological Survey 1:100,000-scale digital data Albers Equal-Area Conic projection

Standard parallels $33^{\circ} \mathrm{N}$ and $45^{\circ} \mathrm{N}$, central meridian $89^{\circ} \mathrm{W}$

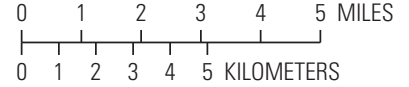

\section{EXPLANATION}

Estimated average annual recharge, in inches per year
- 0 to 1
Greater than 1 to 2
Greater than 2 to 3
Greater than 3 to 4
Greater than 4 to 5
- Not analyzed

Figure 16. Estimated average recharge at selected unconfined and semi-confined wells in McHenry County, Illinois. Two wells were not included in the recharge estimates because of pumping influences. 


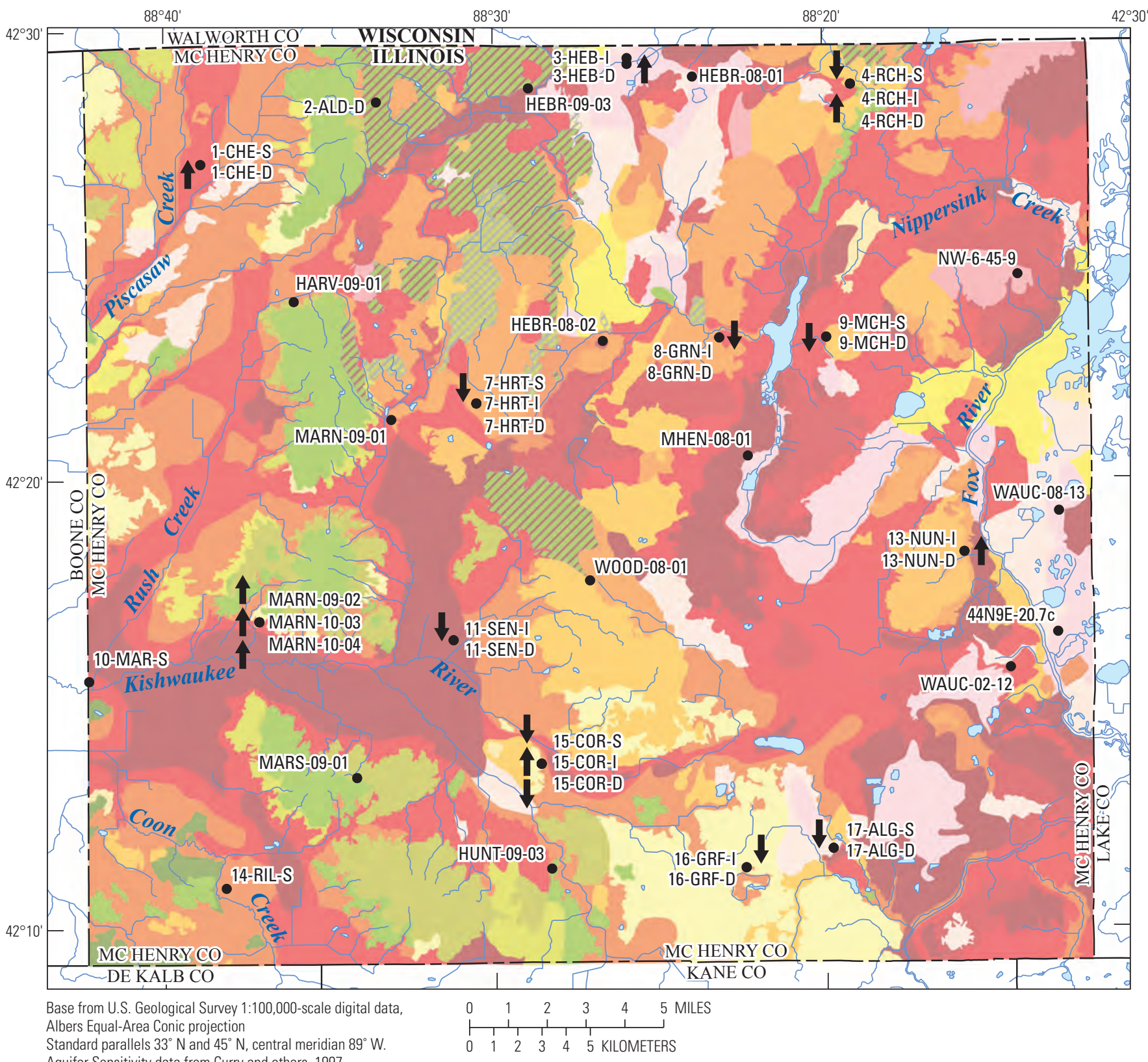

\section{EXPLANATION}
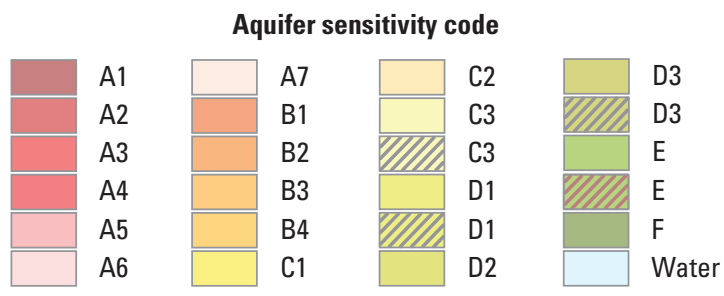

HUNT-09-03 Well with identifier

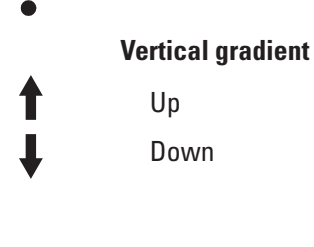

Figure 17. Aquifer sensitivity and vertical gradients at wells in the McHenry County groundwater monitoring network, Illinois. Modified from Curry and others (1997, pl. 1). [Aquifer sensitivity codes A1-B4 indicate the greatest potential for contamination because of little to no fine-grained (clay) materials near the land surface. Aquifer sensitivity codes $\mathrm{C} 1-\mathrm{F}$ indicate a moderate to low potential for aquifer contamination because of greater thickness ( 20 to $100 \mathrm{ft}$ ) of clay materials near the land surface.] 
Previous studies also have shown that the locations of recharge to the deeper confined and semi-confined aquifers are along the groundwater drainage divide near the upland areas created by the Woodstock and Barlina Moraines (fig. 3). Hydrogeologic investigations have identified many areas along this groundwater divide where there is a connection between aquifer units or where the till units are thin (Meyer and others, 2013). This was noted in two well logs showing that the Haeger-Beverly Unit directly overlies the Ashmore Unit in the south-central part of the county at wells 15-COR-S, -I, and -D, and 11-SEN-I and -D along the Barlina Moraine. These two well nests also have generally downward vertical gradients (table 8).

\section{Groundwater-Level Trends}

Hydrographs for each well showing water-level data for 2009-14 were visually evaluated for trends over time. Trends for each monitoring well are shown in figure 18. Most of the

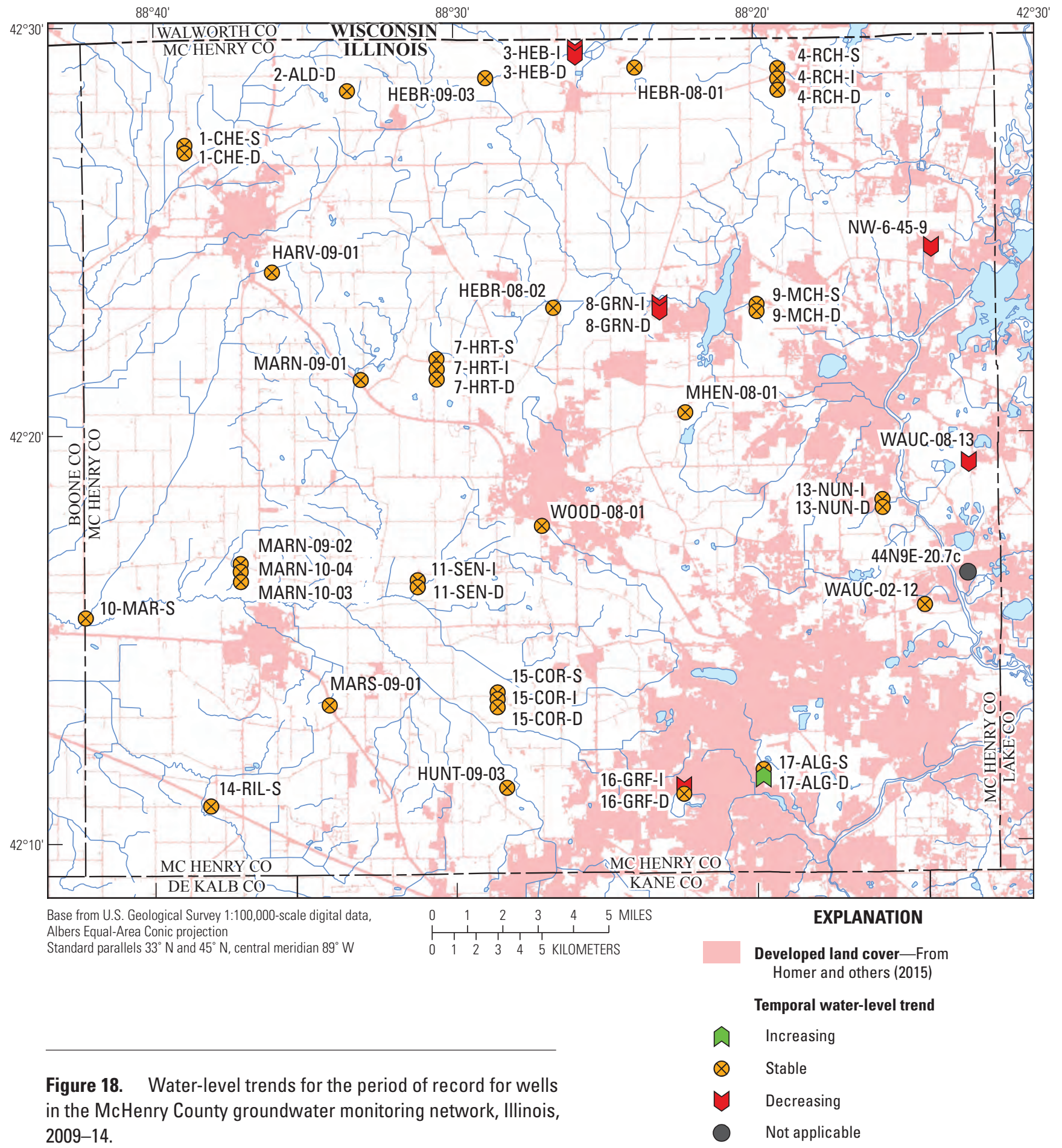


monitoring wells (35 of 44) showed stable water-level trends. A few wells (7 of 44) indicated a decreasing trend (falling levels); all of these wells are in the eastern half of the county. Only one well (17-ALG-D) showed an increasing trend in water levels (rising levels). The trend at well 17-ALG-D may be related to changes in withdrawal rates from a deep supply well near this site.

Because only 5-6 years of data were available for the MCGMN, the persistence of a trend is not certain. Trends presented in this report are likely the response to the wet and dry climatic conditions during the study period, with 2009 being a wet period and 2012 being a drought period. At a few wells (16-GRF-I, WAUC-08-13, 8-GRN-I/D, NW-6-45-9, 3-HEB-I/D), declines in water levels have remained persistent since the 2012 severe drought. Three of the five wells with declining trends have pumping influences, which may be contributing to the delayed recovery since the drought. The drought, coupled with groundwater withdrawals, also may be stressing the system and prolonging the time required for the water levels to recover. The estimated recharge values for monitoring well NW-6-45-9 had a moderate-to-high annual average recharge, but because of the greater distance $(30 \mathrm{ft})$ that the infiltrating precipitation needed to travel to reach the water table, there seems to be a general delay in full recovery at this well. Ten years of water-level records at the four NAWQA wells indicate stable conditions. However, all four NAWQA wells represent the uppermost (less than $58.7 \mathrm{ft}$ below land surface), unconfined aquifer unit (Haegar-Beverly).

The potentiometric level at monitoring well 16-GRF-I typically is about $3 \mathrm{ft}$ higher than that of $16-\mathrm{GRF}-\mathrm{D}$, indicating a downward gradient of flow at these well sites. However, increases in drawdown (presumably from nearby pumping) periodically cause the water levels in the intermediate (I) well to decline close to or below the levels in the deep well, particularly during dry periods (fig. 19). This results in temporary reversals in the vertical-flow direction at the two wells. For the period of study, temporal trends at 16-GRF-I indicate a decline in water level over time. This suggests that withdrawals and recharge may not be in equilibrium in this area. Continued monitoring of water levels at 16-GRF-I would allow determination of whether water levels would stabilize at a new, lower level, or if they would continue to decline. As the population expands and additional demands are placed on the aquifers in these areas, water availability from nearby domestic and public-supply wells, and discharge to surface waters might be affected by the drawdown.

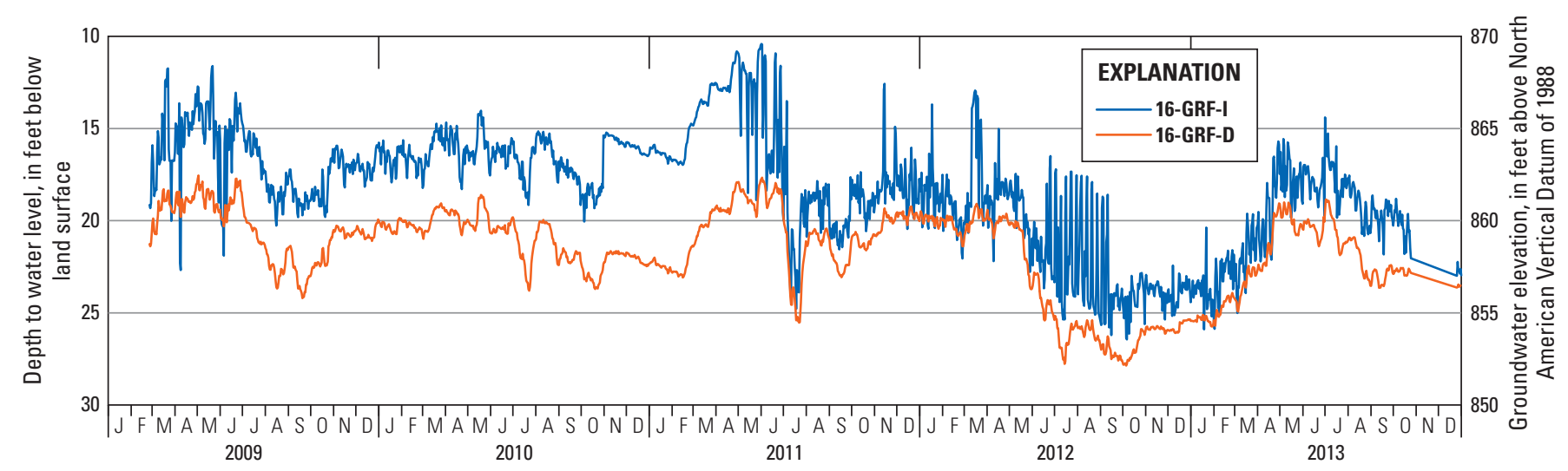

Figure 19. Flow reversals as water levels in the intermediate well (16-GRF-I) declined below the water levels of the deep well (16-GRF-D), McHenry County, Illinois, 2009-13. 


\section{Water Quality of Sand and Gravel Aquifers in McHenry County}

Water-quality data include field measurements of specific conductance, $\mathrm{pH}$, water temperature, $\mathrm{DO}$, alkalinity, and iron (II) and laboratory analyses for major ions, metals, nutrients, dissolved gases, and trace elements. Water-quality samples were collected from 41 wells of the MCGMN and from five additional monitoring wells in the USGS NAWQA network. Construction was not completed for two monitoring wells from the MCGMN (MARN-10-03 and MARN-10-04) at the time of sampling. Field measurements were obtained and water-quality samples were collected during June-November 2010. One water-quality sample was collected at each well. Volatile organic compounds (VOCs) were analyzed at 16 shallow wells (less than $60 \mathrm{ft}$ below land surface) in urban or rural settings with the greatest potential for influence by human activities at land surface (compared to wells screened in deeper parts of the glacial sand and gravel aquifers). Water-quality samples collected from eight of the 16 shallow wells were analyzed for pesticides, dissolved gases, and trace elements. In addition to the 2010 data, concentrations of chloride and specific conductance values were obtained from the periodic samples at select monitoring wells between 2009 and 2015. These additional water-quality samples were collected at sites with continuous monitoring of specific conductance to develop a regression model between specific conductance values and chloride concentrations.

Water-quality sample results are compared to National Primary Drinking Water Regulations established as mandatory Maximum Contaminant Levels (MCLs) as indicators of health risk for drinking water quality by the U.S. Environmental Protection Agency (EPA) (U.S. Environmental Protection Agency, 2012). The National Secondary Drinking Water Standards are non-mandatory Secondary Maximum Contaminant Levels (SMCLs) that are used as indicators for aesthetic (taste, color, and odor) drinking water quality (U.S. Environmental Protection Agency, 1992). Some trace elements and metals are not regulated (no established MCL) by the EPA; however, there is a non-enforceable Health Advisory (HA) standard based on risk for cancer that have a Drinking Water Advisory (DWA) (U.S. Environmental Protection Agency, 2012). Some additional trace elements are unregulated, but have established criteria as Drinking Water Equivalent Levels (DWEL) that are based on the cancer risk data and research. The DWEL is a lifetime exposure limit that assumes 100 percent of the exposure is from that medium, at which adverse, non-carcinogenic health effects would not be expected to occur (U.S. Environmental Protection Agency, 2012). Additionally, the EPA chronic and acute aquatic toxicity levels for select concentrations (such as chloride) in ambient surface waters (U.S. Environmental Protection Agency, 1988) also are discussed. Exceedances for health-based and aesthetic-based benchmarks for drinking and ambient water quality are shown in table 14 .
EPA criteria for chronic and acute toxicity levels in ambient surface waters were considered because of the close proximity of some of the monitoring wells to nearby surface water. Groundwater discharge is a component of base flow, as it contributes to sustained streamflow. Base flow is commonly a prevailing component of surface water during fair weather periods of low flow with limited surface runoff. Chloride in particular will readily enter the stream from the groundwater discharge and potentially increase the concentrations within the stream.

\section{Field Parameters and Major lons}

Results for the field parameters (field-determined characteristics of water quality) are presented in table 15 , and laboratory analyzed major and minor ions are presented in table 16. Dissolved-oxygen ranged from a concentration of about 0 to $4 \mathrm{mg} / \mathrm{L}$ with a median of $0.3 \mathrm{mg} / \mathrm{L}$. Concentrations of DO were less than $1.0 \mathrm{mg} / \mathrm{L}$ in more than 70 percent of the water-quality samples collected. Groundwater sites where DO was less than $1.0 \mathrm{mg} / \mathrm{L}$ are indicative of naturally occurring anaerobic (or reducing) conditions resulting from the oxidation of organic carbon or minerals such as, but not limited to, pyrite and siderite (Mashburn and others, 2003; Dinicola, 2006). Oxygen enters the groundwater by way of recharge from oxygenated surface waters and infiltrating precipitation.

Values of $\mathrm{pH}$ for all water-quality samples were within a near neutral range of 6.8 to 7.8 , with a median $\mathrm{pH}$ of 7.4 (table 15). The $\mathrm{pH}$ of water is a measure of acidity or basicity of water (U.S. Geological Survey, 2016d). The pH determines solubility in water. Low $\mathrm{pH}$ (increased acidity) dissolves heavy metals; weakly acidic waters can dissolve carbonates and other inorganic and organic materials. Such dissolution can contribute to increased total dissolved solids (TDS) in freshwater systems. High $\mathrm{pH}$ causes a bitter taste and reduces the effectiveness of chlorination as a treatment of drinking water (U.S. Geological Survey, 2016d).

Specific conductance for all water-quality samples ranged from 512 to 2,260 microsiemens per centimeter at $25^{\circ} \mathrm{C}(\mu \mathrm{S} / \mathrm{cm})$, with a median value of $760 \mu \mathrm{S} / \mathrm{cm}$ (table 15$)$. The highest values were detected in water-quality samples from shallow (less than $100 \mathrm{ft}$ below land surface) wells adjacent to major roads with greater than 20 percent urban area in the 1,640-foot radial buffer zone around each well (fig. 20), which could indicate that elevated specific conductance is associated with elevated chloride concentrations potentially attributable to road-salt applications.

Values of TDS ranged from 287 to $1,270 \mathrm{mg} / \mathrm{L}$, with a median TDS of $456.5 \mathrm{mg} / \mathrm{L}$ (table 15). TDS represents the amount of dissolved inorganic salts (sodium, calcium, magnesium, sulfates, chloride potassium, and bicarbonates) (Tchobanoglous and Schroeder, 1985). The recommended SMCL for TDS is $500 \mathrm{mg} / \mathrm{L}$ and TDS exceeded the SMCL in 33 percent ( 15 of 46 ) of water-quality samples. 
Table 14. Health- and aesthetically based benchmarks in water-quality samples collected from 46 monitoring wells in 2010 , and periodic water-quality samples collected during 2011-15 in the McHenry County groundwater monitoring network, Illinois.

[Water-quality standard and benchmark concentration: From U.S. Environmental Protection Agency (1992, 2012, 2015). DWA, drinking water advisory; MCL, maximum contaminant level; SMCL, secondary maximum contaminant level. Aquatic ambient water-quality criteria: From U.S. Enviromental Protection Agency (1988). Abbreviations: $\mu \mathrm{g} / \mathrm{L}$, microgram per liter; $\mathrm{mg} / \mathrm{L}$, milligram per liter; >, greater than]

\begin{tabular}{|c|c|c|c|c|c|c|c|c|}
\hline \multirow{2}{*}{ Constituent } & \multirow{2}{*}{$\begin{array}{l}\text { Water-quality } \\
\text { standard and } \\
\text { benchmark } \\
\text { concentration }\end{array}$} & \multicolumn{2}{|c|}{$\begin{array}{c}\text { Aquatic ambient } \\
\text { water-quality criteria }\end{array}$} & \multirow{2}{*}{$\begin{array}{l}\text { Concentration } \\
(\mu \mathrm{g} / \mathrm{L})\end{array}$} & \multicolumn{2}{|c|}{$\begin{array}{l}\text { Number of wells } \\
\text { exceeding benchmark }\end{array}$} & \multirow{2}{*}{$\begin{array}{l}\text { Common sources } \\
\text { of constituent }\end{array}$} & \multirow{2}{*}{$\begin{array}{l}\text { Potential effect } \\
\text { of exceedance } \\
\text { on health } \\
\text { (with long-term } \\
\text { exposure) }\end{array}$} \\
\hline & & Acute & Chronic & & $\begin{array}{l}\text { Drinking } \\
\text { water }\end{array}$ & Ambient & & \\
\hline \multicolumn{9}{|c|}{ Health-based benchmark } \\
\hline Arsenic & $\mathrm{MCL}=10 \mu \mathrm{g} / \mathrm{L}$ & $340 \mu \mathrm{g} / \mathrm{L}$ & $150 \mu \mathrm{g} / \mathrm{L}$ & $\begin{array}{l}\text { Maximum }=62 \\
\text { Minimum }=0.15 \\
\text { Median }=0.85\end{array}$ & 11 & 0 & $\begin{array}{l}\text { Aquifer sediments } \\
\text { and rocks }\end{array}$ & $\begin{array}{l}\text { Skin damage; problems } \\
\text { with circulatory } \\
\text { systems; potentially } \\
\text { carcinogenic }\end{array}$ \\
\hline Sodium & $\begin{array}{r}\text { DWA }=20 \mathrm{mg} / \mathrm{L} \\
\quad(20,000 \mu \mathrm{g} / \mathrm{L})\end{array}$ & None & None & $\begin{array}{l}\text { Maximum }=181,000 \\
\text { Minimum }=3,900 \\
\text { Median }=124,000\end{array}$ & 17 & & $\begin{array}{l}\text { Road salt; septic } \\
\text { leachate; } \\
\text { water softener } \\
\text { regeneration; } \\
\text { aquifer rocks }\end{array}$ & $\begin{array}{l}\text { May increase blood } \\
\text { pressure in at-risk } \\
\text { individuals }\end{array}$ \\
\hline Manganese & $\begin{array}{l}\text { DWA }=0.3 \mathrm{mg} / \mathrm{L} \\
\quad(300 \mathrm{ug} / \mathrm{L})\end{array}$ & None & None & $\begin{array}{l}\text { Maximum }=667 \\
\text { Minimum }=0.5 \\
\text { Median }=29.8\end{array}$ & 1 & & $\begin{array}{l}\text { Aquifer sediments } \\
\text { and rocks, } \\
\text { industrial } \\
\text { effluent, acid- } \\
\text { mine drainage, } \\
\text { sewage, landfill } \\
\text { leachate. }\end{array}$ & $\begin{array}{l}\text { Toxicity to nervous } \\
\text { system }\end{array}$ \\
\hline Nitrate & $\mathrm{MCL}=10 \mathrm{mg} / \mathrm{L}$ & None & None & $\begin{array}{l}\text { Maximum }=10 \\
\text { Minimum }=0.06 \\
\text { Median }=1.44\end{array}$ & 1 & & $\begin{array}{l}\text { Septic leachate; } \\
\text { seepage from } \\
\text { fertilizers }\end{array}$ & $\begin{array}{l}\text { May cause } \\
\text { methemoglobinemia } \\
\text { (blue-baby syndrome) } \\
\text { in infants }\end{array}$ \\
\hline \multicolumn{9}{|c|}{ Aesthetically-based benchmark } \\
\hline $\begin{array}{l}\text { Total dissolved } \\
\text { solids (TDS) }\end{array}$ & $500 \mathrm{mg} / \mathrm{L}$ & None & None & $\begin{array}{l}\text { Maximum }=1,270 \\
\text { Minimum }=287 \\
\text { Median }=456.5\end{array}$ & 15 & & $\begin{array}{l}\text { Road salt; brines; } \\
\text { septic leachate; } \\
\text { dissolved aquifer } \\
\text { minerals }\end{array}$ & $\begin{array}{l}\text { Concentrations } \\
>1,000 \mathrm{mg} / \mathrm{L} \text { may } \\
\text { cause objectionable } \\
\text { tastes and laxative } \\
\text { effects. May also } \\
\text { cause foaming or } \\
\text { corrosion of metals. }\end{array}$ \\
\hline Manganese & $\mathrm{SMCL}=50 \mu \mathrm{g} / \mathrm{L}$ & None & None & $\begin{array}{l}\text { Maximum }=667 \\
\text { Minimum }=0.5 \\
\text { Median }=29.8\end{array}$ & 14 & & $\begin{array}{l}\text { Aquifer sediments } \\
\text { and rocks }\end{array}$ & $\begin{array}{l}\text { Dark-brown or black } \\
\text { staining of fixtures } \\
\text { and laundry. May have } \\
\text { black particulates at } \\
\text { high concentrations. }\end{array}$ \\
\hline
\end{tabular}


Table 15. Well sampling details and field parameters for wells in the McHenry County groundwater monitoring network, Illinois, 2010.

[Locations of monitoring wells are shown in figure 1. Abbreviations: $\mathrm{ft}$, foot; ${ }^{\circ} \mathrm{C}$, degrees Celsius; $\mu \mathrm{S} / \mathrm{cm}$, microsiemens per centimeter at $25{ }^{\circ} \mathrm{C}$; mg/L, milligram per liter; mmHg, millimeters of mercury; No., number; NTU, Nephelometric Turbidity Unit; USGS, U.S. Geological Survey]

\begin{tabular}{|c|c|c|c|c|c|c|c|c|c|c|}
\hline \multirow[b]{2}{*}{$\begin{array}{c}\text { Monitoring } \\
\text { well }\end{array}$} & \multicolumn{10}{|c|}{ Well sampling details } \\
\hline & $\begin{array}{c}\text { USGS station } \\
\text { No. }\end{array}$ & Date & $\begin{array}{l}\text { Land } \\
\text { surface } \\
\text { altitude } \\
\text { (ft) }\end{array}$ & $\begin{array}{c}\text { Depth } \\
\text { of well } \\
\text { (ft) }\end{array}$ & $\begin{array}{l}\text { Depth to } \\
\text { bottom of } \\
\text { screen } \\
\text { interval } \\
\text { (ft) }\end{array}$ & $\begin{array}{l}\text { Depth to } \\
\text { top of } \\
\text { screen } \\
\text { interval } \\
\text { (ft) } \\
\end{array}$ & $\begin{array}{c}\text { Pumping } \\
\text { period } \\
\text { (minutes) }\end{array}$ & $\begin{array}{c}\text { Sampling } \\
\text { depth } \\
\text { (ft) }\end{array}$ & $\begin{array}{c}\text { Air } \\
\text { temperature } \\
\left({ }^{\circ} \mathrm{C}\right)\end{array}$ & $\begin{array}{l}\text { Water level } \\
\text { (ft below } \\
\text { land } \\
\text { surface } \\
\text { datum) }\end{array}$ \\
\hline 14-RIL-S & 421056088380801 & $10-12-10$ & 807 & 20.4 & 19.9 & 15.4 & 86 & 15 & 23.4 & 8.83 \\
\hline HUNT-09-03 & 421120088281801 & $10-26-10$ & 878 & 150.7 & 150.4 & 14.4 & 80 & 44 & 12.1 & 28.29 \\
\hline 16-GRF-I & 421122088222701 & $10-13-10$ & 880 & 99 & 98.5 & 94 & 104 & 35 & 14.5 & 16.46 \\
\hline 16-GRF-D & 421122088222702 & $10-13-10$ & 880 & 139.1 & 138.6 & 134.1 & 94 & 48 & 17.1 & 22.97 \\
\hline 17-ALG-S & 421145088194801 & $09-22-10$ & 880 & 47.3 & 46.8 & 42.3 & 108 & 42 & 23.1 & 2.52 \\
\hline 17-ALG-D & 421145088194802 & $11-16-10$ & 880 & 187.8 & 187.3 & 182.8 & 86 & 123 & 4.9 & 96.69 \\
\hline $43 \mathrm{~N} 8 \mathrm{E}-8.2 \mathrm{c}^{1}$ & 421301088191501 & $07-13-10$ & 900 & 46.1 & 45.6 & 40.6 & 60 & 38 & 27.1 & 22.28 \\
\hline MARS-09-01 & 421321088341101 & $11-01-10$ & 928 & 190.3 & 190 & 185 & 136 & 90 & 12.1 & 74.62 \\
\hline 15-COR-S & 421341088283701 & $10-27-10$ & 851 & 55.1 & 54.6 & 50.1 & 50 & 21 & 11 & 10.44 \\
\hline 15-COR-I & 421341088283702 & $10-14-10$ & 851 & 103.3 & 102.8 & 98.3 & 65 & 31.5 & 6 & 10 \\
\hline 15-COR-D & 421341088283703 & $10-27-10$ & 851 & 116.1 & 115.6 & 111.1 & 59 & 24 & 13.9 & 10.45 \\
\hline $43 \mathrm{~N} 8 \mathrm{E}-3.7 \mathrm{~d}^{1}$ & 421402088173501 & $07-13-10$ & 920 & 58.7 & 58.2 & 53.2 & 35 & 50 & 23.1 & 37.25 \\
\hline 10-MAR-S & 421533088421801 & $11-04-10$ & 781 & 20.3 & 19.8 & 15.3 & 28 & 10 & 3.8 & 5.94 \\
\hline WAUC-02-12 & 421547088142301 & $11-16-10$ & 835 & 192.3 & 192 & 187 & 47 & 152 & 10 & 94.07 \\
\hline 11-SEN-I & 421626088311401 & $10-26-10$ & 831 & 75.4 & 74.9 & 70.4 & 74 & 25 & 14.9 & 5.05 \\
\hline 11-SEN-D & 421626088311402 & $10-26-10$ & 831 & 153.2 & 152.7 & 148.2 & 87 & 25 & 12.9 & 5.97 \\
\hline 44N9E-20.7c & 421633088125801 & $06-09-10$ & 750 & 26.1 & 25.6 & 20.6 & 79 & 20 & 19.6 & 12.01 \\
\hline MARN-09-02 & 421653088370901 & $10-18-10$ & 827 & 110.6 & 110.3 & 105.3 & 76 & 40 & 16.5 & 19.23 \\
\hline WOOD-08-01 & 421747088270701 & $11-17-10$ & 943 & 202.3 & 202 & 197 & 119 & 87 & 6.5 & 79.4 \\
\hline 13-NUN-I & 421820088154501 & $11-15-10$ & 785 & 113 & 112.5 & 108 & 51 & 58 & 10.7 & 47.18 \\
\hline 13-NUN-D & 421820088154502 & $11-15-10$ & 785 & 152.2 & 151.7 & 147.2 & 87 & 60 & 10.9 & 47.04 \\
\hline WAUC-08-13 & 421914088125301 & $10-25-10$ & 766 & 105.3 & 105 & 100 & 56 & 42 & 22.2 & 21.38 \\
\hline $45 \mathrm{~N} 7 \mathrm{E}-32.4 \mathrm{~d}^{1}$ & 422002088263001 & $07-12-10$ & 900 & 30.4 & 29.9 & 24.9 & 42 & 29 & 24.9 & 25.93 \\
\hline MHEN-08-01 & 422032088222001 & $10-20-10$ & 860 & 103.3 & 103 & 98 & 59 & 50 & 20.7 & 34.74 \\
\hline MARN-09-01 & 422120088330901 & $10-27-10$ & 909 & 100.7 & 100.4 & 95.4 & 60 & 50 & 17.4 & 34.32 \\
\hline 7-HRT-S & 422142088303101 & $10-20-10$ & 924 & 62.3 & 61.8 & 57.3 & 50 & 49.5 & 6.8 & 37.56 \\
\hline 7-HRT-I & 422142088303102 & $10-20-10$ & 924 & 114.9 & 114.4 & 109.9 & 60 & 59 & 13.4 & 37.88 \\
\hline 7-HRT-D & 422142088303103 & $10-20-10$ & 924 & 165.7 & 165.2 & 160.7 & 90 & 61 & 17.4 & 38.48 \\
\hline 9-MCH-S & 422308088195601 & $09-22-10$ & 863 & 25.9 & 25.4 & 20.9 & 39 & 22 & 17 & 10.67 \\
\hline 9-MCH-D & 422308088195602 & $10-13-10$ & 863 & 180 & 179.5 & 175 & 135 & 84 & 17.6 & 54.47 \\
\hline 8-GRN-I & 422308088231001 & $11-02-10$ & 856 & 70.3 & 69.8 & 65.3 & 36 & 18 & 11.8 & 6.2 \\
\hline 8-GRN-D & 422308088231002 & $11-02-10$ & 856 & 153.1 & 152.6 & 148.1 & 64 & 29 & 10.9 & 17.53 \\
\hline HEBR-08-02 & 422308088264201 & $10-21-10$ & 898 & 100.3 & 100 & 95 & 53 & 28.5 & 3.5 & 11.96 \\
\hline $45 \mathrm{~N} 9 \mathrm{E}-7.6 \mathrm{a}^{1}$ & 422314088140001 & $06-09-10$ & 780 & 13.6 & 13.1 & 8.1 & 47 & 11 & 19.6 & 5.75 \\
\hline HARV-09-01 & 422358088360201 & $10-19-10$ & 942 & 120.1 & 119.8 & 114.8 & 68 & 45 & 6 & 32.12 \\
\hline NW-6-45-9 & 422433088140601 & $11-16-10$ & 855 & 73 & 73 & 65 & 42 & 52 & 13.5 & 30.63 \\
\hline 1-CHE-S & 422704088385301 & $10-19-10$ & 896 & 40.3 & 39.8 & 35.3 & 32 & 19 & 14.8 & 8.37 \\
\hline 1-CHE-D & 422704088385302 & $10-19-10$ & 899 & 110.8 & 110.3 & 105.8 & 93 & 80 & 14.8 & 8.09 \\
\hline 2-ALD-D & 422828088333301 & $11-17-10$ & 1,176 & 344.4 & 343.9 & 339.4 & 62 & E240 & 5.9 & 219.86 \\
\hline HEBR-09-03 & 422845088285401 & $11-17-10$ & 949 & 120.6 & 120.3 & 115.3 & 48 & 40 & 6.9 & 26.05 \\
\hline 4-RCH-S & 422848088191001 & $09-21-10$ & 844 & 24 & 23.5 & 19 & 92 & 22 & 30.9 & 9.16 \\
\hline 4-RCH-I & 422848088191002 & $11-02-10$ & 844 & 98.3 & 97.8 & 93.3 & 54 & 26.5 & 8.8 & 13.62 \\
\hline 4-RCH-D & 422848088191003 & $11-02-10$ & 844 & 176 & 175.5 & 171 & 128 & 20 & 2.3 & 12.16 \\
\hline HEBR-08-01 & 422858088235601 & $11-03-10$ & 898 & 145.3 & 145 & 140 & 70 & 41 & 13.2 & 28.89 \\
\hline 3-HEB-I & 422925088255401 & $11-03-10$ & 868 & 66.3 & 65.8 & 61.3 & 35 & 0 & 3 & -12.44 \\
\hline 3-HEB-D & 422925088255402 & $11-03-10$ & 868 & 94.4 & 93.9 & 89.4 & 43 & 0 & 8.5 & -12.47 \\
\hline
\end{tabular}


Table 15. Well sampling details and field parameters for wells in the McHenry County groundwater monitoring network, Illinois, 2010. - Continued

\begin{tabular}{|c|c|c|c|c|c|c|c|}
\hline \multirow[b]{2}{*}{$\begin{array}{c}\text { Monitoring } \\
\text { well }\end{array}$} & \multicolumn{7}{|c|}{ Field parameters } \\
\hline & $\begin{array}{l}\text { Air pressure } \\
(\mathrm{mmHg})\end{array}$ & $\begin{array}{c}\text { Dissolved } \\
\text { oxygen } \\
\text { (mg/L) }\end{array}$ & $\begin{array}{l}\text { pH, std } \\
\text { units }\end{array}$ & $\begin{array}{l}\text { Total dissolved } \\
\text { solids } \\
\text { (mg/L) }\end{array}$ & $\begin{array}{c}\text { Specific } \\
\text { conductance } \\
(\mu \mathrm{S} / \mathrm{cm})\end{array}$ & $\begin{array}{c}\text { Water } \\
\text { temperature } \\
\left({ }^{\circ} \mathrm{C}\right)\end{array}$ & $\begin{array}{c}\text { Turbidity } \\
\text { (NTU) }\end{array}$ \\
\hline 14-RIL-S & 739 & 1.5 & 7.3 & 682 & 1,240 & 15.3 & 2.6 \\
\hline HUNT-09-03 & 719 & 0.7 & 7.5 & 495 & 839 & 10.7 & 0.5 \\
\hline 16-GRF-I & 741 & 0.5 & 7.4 & 541 & 904 & 11.9 & 1.1 \\
\hline 16-GRF-D & 742 & 0.3 & 7.8 & 320 & 551 & 12.3 & 1.6 \\
\hline 17-ALG-S & 740 & 0.3 & 7.3 & 497 & 863 & 15.6 & 14 \\
\hline 17-ALG-D & 733 & 0.2 & 7.7 & 349 & 633 & 12.8 & 3.5 \\
\hline $43 \mathrm{~N} 8 \mathrm{E}-8.2 \mathrm{c}^{1}$ & 736 & 4.0 & 7.2 & 708 & 1,280 & 15.2 & 12 \\
\hline MARS-09-01 & 747 & 0 & 7.6 & 358 & 627 & 10.7 & 0.5 \\
\hline 15-COR-S & 727 & 0 & 7.5 & 469 & 787 & 11.8 & 0.9 \\
\hline 15-COR-I & 742 & 1.5 & 7.4 & 472 & 783 & 11.2 & 1.2 \\
\hline 15-COR-D & 728 & 0 & 7.3 & 504 & 850 & 12.6 & 1.5 \\
\hline $43 \mathrm{~N} 8 \mathrm{E}-3.7 \mathrm{~d}^{1}$ & 735 & & 7.1 & 715 & 1,230 & 16.1 & 0.6 \\
\hline 10-MAR-S & 738 & & 7.3 & 438 & 730 & 12.4 & 2.2 \\
\hline WAUC-02-12 & 730 & 0.2 & 7.7 & 305 & 526 & 12.2 & 0.8 \\
\hline 11-SEN-I & 716 & 0.4 & 7.7 & 382 & 660 & 12.4 & 0.6 \\
\hline 11-SEN-D & 718 & 0 & 7.7 & 349 & 622 & 10.9 & 0.4 \\
\hline 44N9E-20.7c & 737 & 0.1 & 7.0 & 1,070 & 1,960 & 16.3 & 21 \\
\hline MARN-09-02 & 742 & 0 & 7.4 & 399 & 683 & 12.4 & 1 \\
\hline WOOD-08-01 & 738 & 1.8 & 7.4 & 407 & 694 & 10.9 & 0.5 \\
\hline 13-NUN-I & 737 & 0.9 & 7.6 & 357 & 608 & 10.8 & 1.1 \\
\hline 13-NUN-D & 737 & 1.2 & 7.6 & 382 & 644 & 11 & 0.5 \\
\hline WAUC-08-13 & 730 & 1.0 & 7.3 & 456 & 766 & 12.6 & 0.2 \\
\hline $45 \mathrm{~N} 7 \mathrm{E}-32.4 \mathrm{~d}^{1}$ & 733 & 1.3 & 6.8 & 595 & 1,070 & 14.9 & 0.6 \\
\hline MHEN-08-01 & 731 & 0.1 & 7.1 & 506 & 893 & 11.4 & 0.5 \\
\hline MARN-09-01 & 726 & 0.1 & 7.4 & 408 & 718 & 11.5 & 0.3 \\
\hline 7-HRT-S & 732 & 0 & 7.2 & 604 & 1,060 & 11.5 & 19 \\
\hline 7-HRT-I & 732 & 0.1 & 7.5 & 366 & 614 & 12.2 & 0.6 \\
\hline 7-HRT-D & 732 & 0 & 7.4 & 372 & 652 & 12.8 & 0.7 \\
\hline 9-MCH-S & 740 & 2.1 & 7.0 & 757 & 1,360 & 15.7 & 7.3 \\
\hline 9-MCH-D & 741 & 0.3 & 7.8 & 295 & 527 & 11.9 & 0.6 \\
\hline 8-GRN-I & 748 & 1.8 & 7.3 & 553 & 918 & 10.7 & 0.9 \\
\hline 8-GRN-D & 748 & 0.9 & 7.6 & 355 & 591 & 10.6 & 0.8 \\
\hline HEBR-08-02 & 737 & 0.6 & 7.4 & 482 & 805 & 10.3 & 0.3 \\
\hline 45 N9E-7.6a ${ }^{1}$ & 737 & 0.5 & 6.9 & 949 & 1,580 & 13 & 0.8 \\
\hline HARV-09-01 & 738 & 0 & 7.1 & 489 & 1,120 & 11.2 & 0.3 \\
\hline NW-6-45-9 & 731 & 0 & 7.2 & 522 & 899 & 12 & 0.4 \\
\hline 1-CHE-S & 738 & 0.3 & 7.1 & 602 & 991 & 11.5 & 1.1 \\
\hline 1-CHE-D & 738 & 0 & 7.7 & 287 & 512 & 12 & 8.5 \\
\hline 2-ALD-D & 729 & 0.1 & 7.7 & 315 & 534 & 13.3 & 11 \\
\hline HEBR-09-03 & 737 & 1.0 & 7.4 & 457 & 754 & 10.3 & 0.6 \\
\hline 4-RCH-S & 736 & 0.8 & 7.2 & 1,270 & 2,260 & 19.6 & 6.6 \\
\hline 4-RCH-I & 751 & 1.4 & 7.6 & 316 & 550 & 11.2 & 1.2 \\
\hline 4-RCH-D & 737 & 1.4 & 7.6 & 307 & 530 & 11.6 & 72 \\
\hline HEBR-08-01 & 735 & 0.8 & 7.7 & 312 & 576 & 11 & 0.4 \\
\hline 3-HEB-I & 740 & 0.1 & 7.6 & 454 & 754 & 10.1 & 3.3 \\
\hline 3-HEB-D & 738 & 0.1 & 7.6 & 464 & 774 & 10.4 & 4.3 \\
\hline
\end{tabular}

${ }^{1}$ USGS National Water-Quality Assessment program monitoring wells were included in 2010 sampling periods, but were not equipped with real-time instrumentation. 
Table 16. Major and minor ions from wells in the McHenry County groundwater monitoring network and four wells from the National Water-Quality Assessment program, McHenry County, Illinois, 2010.

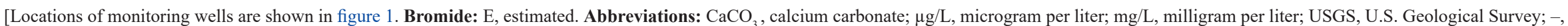
no data]

\begin{tabular}{|c|c|c|c|c|c|c|c|c|c|c|c|c|c|}
\hline \multirow{2}{*}{$\begin{array}{l}\text { Monitoring } \\
\text { well }\end{array}$} & \multirow{2}{*}{$\begin{array}{c}\text { Calcium } \\
\text { (mg/L) }\end{array}$} & \multirow{2}{*}{$\begin{array}{l}\text { Magnesium } \\
\qquad(\mathrm{mg} / \mathrm{L})\end{array}$} & \multirow{2}{*}{$\begin{array}{l}\text { Potassium } \\
\text { (mg/L) }\end{array}$} & \multirow{2}{*}{$\begin{array}{l}\text { Manganese } \\
(\mu \mathrm{g} / \mathrm{L})\end{array}$} & \multirow{2}{*}{$\begin{array}{l}\text { Chloride } \\
\text { (mg/L) }\end{array}$} & \multirow{2}{*}{$\begin{array}{l}\text { Sodium } \\
\text { (mg/L) }\end{array}$} & \multirow{2}{*}{$\begin{array}{c}\text { Hardness, } \\
\text { (mg/L as } \\
\mathrm{CaCO}_{3} \text { ) }\end{array}$} & \multicolumn{2}{|c|}{ Alkalinity (mg/L as $\mathrm{CaCO}_{3}$ ) } & \multirow{2}{*}{$\begin{array}{c}\text { Bromide } \\
\text { (mg/L) }\end{array}$} & \multirow{2}{*}{$\begin{array}{c}\text { Fluoride } \\
\text { (mg/L) }\end{array}$} & \multirow{2}{*}{$\begin{array}{l}\text { Silica } \\
(\mathrm{mg} / \mathrm{L})\end{array}$} & \multirow{2}{*}{$\begin{array}{l}\text { Sulfate } \\
\text { (mg/L) }\end{array}$} \\
\hline & & & & & & & & Laboratory & Field & & & & \\
\hline 14-RIL-S & 76.2 & 37.3 & 1.86 & 27.5 & 200 & 111 & 344 & 289 & - & 0.06 & 0.19 & 13.4 & 23.9 \\
\hline HUNT-09-03 & 78.7 & 39.5 & 1.49 & 24.7 & 14.1 & 50 & 359 & 423 & - & 0.04 & 0.42 & 18.9 & 35.0 \\
\hline 16-GRF-I & 93.8 & 48.5 & 2.32 & 29.3 & 82.0 & 23.4 & 434 & - & - & 0.07 & 0.42 & 21.2 & 48.3 \\
\hline 16-GRF-D & 44.1 & 33.6 & 1.56 & 7.9 & 6.06 & 22.7 & 249 & 288 & - & 0.02 & 0.68 & 18 & 18.4 \\
\hline 17-ALG-S & 86.8 & 46.1 & 1.32 & 30.2 & 39.5 & 30 & 408 & - & 383 & E0.02 & 0.31 & 15.8 & 41.9 \\
\hline 17-ALG-D & 41.8 & 28.6 & 1.96 & 6.0 & 41.4 & 49.4 & 222 & 276 & - & 0.08 & 0.72 & 14.4 & 3.28 \\
\hline $43 \mathrm{~N} 8 \mathrm{E}-8.2 \mathrm{c}^{1}$ & 101 & 48 & 3.18 & 1.7 & 197 & 93.2 & & - & 344 & 0.06 & 0.14 & 14.9 & 37.2 \\
\hline MARS-09-01 & 52.4 & 34.2 & 1.98 & 27.8 & 1.34 & 30.6 & 272 & 356 & - & 0.02 & 0.36 & 19.7 & 1.30 \\
\hline 15-COR-S & 92.8 & 46 & 1.29 & 40.5 & 14.9 & 7.81 & 422 & 337 & - & 0.05 & 0.45 & 19.1 & 81.1 \\
\hline 15-COR-I & 91.5 & 46.5 & 1.43 & 43.5 & 18.5 & 7.61 & 420 & 331 & - & 0.05 & 0.46 & 18.8 & 85.4 \\
\hline 15-COR-D & 100 & 47 & 1.52 & 58.9 & 30.4 & 9.25 & 444 & 320 & - & 0.05 & 0.37 & 18.7 & 101 \\
\hline $43 \mathrm{~N} 8 \mathrm{E}-3.7 \mathrm{~d}^{1}$ & 115 & 58.9 & 4.87 & 50 & 149 & 57.3 & & - & 412 & 0.06 & 0.11 & 17.6 & 66.3 \\
\hline 10-MAR-S & 88 & 38.5 & 2.2 & 667 & 31.0 & 8.8 & 378 & 276 & - & 0.04 & 0.14 & 8.0 & 93.2 \\
\hline WAUC-02-12 & 40.1 & 31.6 & 1.73 & 12.4 & 2.7 & 29.6 & 320 & 294 & - & 0.03 & 0.76 & 20.1 & 0.67 \\
\hline 11-SEN-I & 79.5 & 38.6 & 1.72 & 42.7 & 8.53 & 4.1 & 357 & 306 & - & 0.04 & 0.23 & 18.2 & 45.9 \\
\hline 11-SEN-D & 66 & 38 & 1.69 & 23.7 & 1.61 & 10.9 & 322 & 348 & - & 0.02 & 0.39 & 19.0 & $<0.09$ \\
\hline 44N9E-20.7c & 126 & 59.4 & 2.18 & 87.5 & 400 & 171 & 560 & - & 383 & 0.06 & 0.14 & 14.2 & 46.9 \\
\hline MARN-09-02 & 71.1 & 39.7 & 1.85 & 29.4 & 1.31 & 22.2 & 341 & 391 & - & 0.03 & 0.42 & 23.6 & $<0.09$ \\
\hline WOOD-08-01 & 77.8 & 45.3 & 1.53 & 56.3 & 0.49 & 10.8 & 381 & 410 & - & 0.01 & 0.50 & 22.5 & $<0.09$ \\
\hline 13-NUN-I & 66.6 & 38.4 & 1.31 & 14.6 & 1.34 & 10.1 & 324 & 334 & - & 0.02 & 0.56 & 20.1 & 15.7 \\
\hline 13-NUN-D & 67.1 & 39.8 & 1.53 & 9.9 & 8.62 & 17.7 & 332 & 318 & - & 0.03 & 0.48 & 20.6 & 34.9 \\
\hline WAUC-08-13 & 92 & 47.1 & 1.48 & 38.7 & 3.94 & 8.75 & 424 & 385 & - & 0.02 & 0.23 & 22.0 & 48.2 \\
\hline $45 \mathrm{~N} 7 \mathrm{E}-32.4 \mathrm{~d}^{1}$ & 130 & 59.1 & 2.59 & 92.4 & 75.4 & 14.5 & - & - & 489 & 0.02 & 0.17 & 15.4 & 33.3 \\
\hline MHEN-08-01 & 96.7 & 48.9 & 1.97 & 81.7 & 51.5 & 11.6 & 443 & 362 & - & 0.04 & 0.20 & 19.3 & 56.2 \\
\hline MARN-09-01 & 83.7 & 41.6 & 1.03 & 33.6 & 13.3 & 5.87 & 381 & 351 & - & 0.03 & 0.31 & 18.2 & 28.2 \\
\hline 7-HRT-S & 113 & 54.7 & 1.53 & 63.2 & 91.1 & 19.7 & 507 & 397 & - & 0.03 & 0.19 & 21.1 & 62.9 \\
\hline 7-HRT-I & 70.2 & 34.3 & 1.08 & 15.5 & 0.72 & 7.49 & 317 & 378 & - & 0.02 & 0.34 & 20.8 & 0.09 \\
\hline 7-HRT-D & 73.5 & 37 & 1.35 & 17.6 & 2.49 & 8.38 & 336 & 374 & - & 0.03 & 0.35 & 20.9 & 0.5 \\
\hline 9-MCH-S & 114 & 54.4 & 2.77 & 0.5 & 196 & 88.3 & 510 & - & 381 & 0.12 & 0.23 & 18.1 & 42.0 \\
\hline 9-MCH-D & 38.4 & 25.9 & 1.63 & 27.6 & 1.44 & 33.4 & 203 & 286 & - & 0.02 & 0.72 & 15.4 & 1.96 \\
\hline 8-GRN-I & 111 & 53.8 & 1.93 & 50.9 & 45.6 & 6.98 & 500 & 358 & - & 0.04 & 0.18 & 17.1 & 99.2 \\
\hline 8-GRN-D & 71.2 & 34.9 & 1.44 & 194 & 3.12 & 3.87 & 322 & 286 & - & 0.04 & 0.23 & 19.5 & 47.9 \\
\hline HEBR-08-02 & 91.5 & 46.2 & 2.01 & 76.7 & 22.9 & 9.93 & 419 & 327 & & 0.05 & 0.18 & 16.7 & 94.9 \\
\hline $45 \mathrm{~N} 9 \mathrm{E}-7.6 \mathrm{a}^{1}$ & 134 & 61.3 & 2.39 & 168 & 204 & 114 & & - & 555 & 0.06 & 0.12 & 17.1 & 63.9 \\
\hline HARV-09-01 & 95.4 & 45.8 & 2.37 & 57.3 & 36.7 & 10.3 & 427 & 345 & - & 0.04 & 0.16 & 13.8 & 76.1 \\
\hline
\end{tabular}


Table 16. Major and minor ions from wells in the McHenry County groundwater monitoring network and four wells from the National Water-Quality Assessment program, McHenry County, Illinois, 2010.-Continued

\begin{tabular}{|c|c|c|c|c|c|c|c|c|c|c|c|c|c|}
\hline \multirow{2}{*}{$\begin{array}{l}\text { Monitoring } \\
\text { well }\end{array}$} & \multirow{2}{*}{$\begin{array}{l}\text { Calcium } \\
\text { (mg/L) }\end{array}$} & \multirow{2}{*}{$\begin{array}{l}\text { Magnesium } \\
\text { (mg/L) }\end{array}$} & \multirow{2}{*}{$\begin{array}{l}\text { Potassium } \\
\text { (mg/L) }\end{array}$} & \multirow{2}{*}{$\begin{array}{c}\text { Manganese } \\
(\mu \mathrm{g} / \mathrm{L})\end{array}$} & \multirow{2}{*}{$\begin{array}{l}\text { Chloride } \\
\text { (mg/L) }\end{array}$} & \multirow{2}{*}{$\begin{array}{l}\text { Sodium } \\
\text { (mg/L) }\end{array}$} & \multirow{2}{*}{$\begin{array}{c}\text { Hardness, } \\
\text { (mg/L as } \\
\mathrm{CaCO}_{3} \text { ) }\end{array}$} & \multicolumn{2}{|c|}{ Alkalinity (mg/L as $\mathrm{CaCO}_{3}$ ) } & \multirow{2}{*}{$\begin{array}{c}\text { Bromide } \\
\text { (mg/L) }\end{array}$} & \multirow{2}{*}{$\begin{array}{c}\text { Fluoride } \\
\text { (mg/L) }\end{array}$} & \multirow{2}{*}{$\begin{array}{l}\text { Silica } \\
\text { (mg/L) }\end{array}$} & \multirow{2}{*}{$\begin{array}{l}\text { Sulfate } \\
\text { (mg/L) }\end{array}$} \\
\hline & & & & & & & & Laboratory & Field & & & & \\
\hline NW-6-45-9 & 107 & 52.4 & 1.51 & 44 & 64.0 & 4.4 & 482 & 309 & - & 0.04 & 0.16 & 16.0 & 90.0 \\
\hline 1-CHE-S & 113 & 51 & 7.14 & 148 & 60.3 & 17.1 & 493 & 366 & - & 0.04 & 0.2 & 13.8 & 117 \\
\hline 1-CHE-D & 48.3 & 26.9 & 0.99 & 10.9 & 1.7 & 19.8 & 231 & 290 & - & 0.02 & 0.42 & 10.3 & 0.6 \\
\hline 2-ALD-D & 34 & 18.4 & 2.68 & 9.1 & 5.72 & 60.8 & 161 & 291 & - & 0.05 & 0.85 & 14.7 & 1.74 \\
\hline HEBR-09-03 & 95.4 & 43.3 & 0.78 & 42.1 & 24.9 & 7.08 & 417 & 303 & - & 0.03 & 0.11 & 13.7 & 87.9 \\
\hline 4-RCH-S & 176 & 83.9 & 2.17 & 40.7 & 521 & 181 & 785 & - & 361 & 0.09 & 0.33 & 22.6 & 60.0 \\
\hline 4-RCH-I & 56.6 & 32.6 & 1.78 & 14.3 & 2.53 & 13.2 & 276 & 312 & - & 0.03 & 0.44 & 17.1 & 1.72 \\
\hline 4-RCH-D & 56.9 & 33.2 & 1.25 & 5.8 & 0.66 & 8.37 & 279 & 307 & - & 0.01 & 0.42 & 20.0 & $<0.09$ \\
\hline HEBR-08-01 & 64.3 & 35.9 & 1.09 & 29.2 & 1.7 & 6.65 & 308 & 270 & - & 0.03 & 0.37 & 17.8 & 20.7 \\
\hline 3-HEB-I & 85.1 & 45.4 & 1.13 & 15.2 & 15.2 & 11.6 & 400 & 403 & - & 0.04 & 0.29 & 20.9 & 28.5 \\
\hline 3-HEB-D & 90.8 & 47.8 & 1.08 & 13.6 & 15.2 & 10.6 & 423 & 408 & - & 0.04 & 0.25 & 21.1 & 28.8 \\
\hline
\end{tabular}

${ }^{1}$ USGS National Water-Quality Assessment program monitoring wells were included in 2010 sampling periods, but were not equipped with real-time instrumentation. 


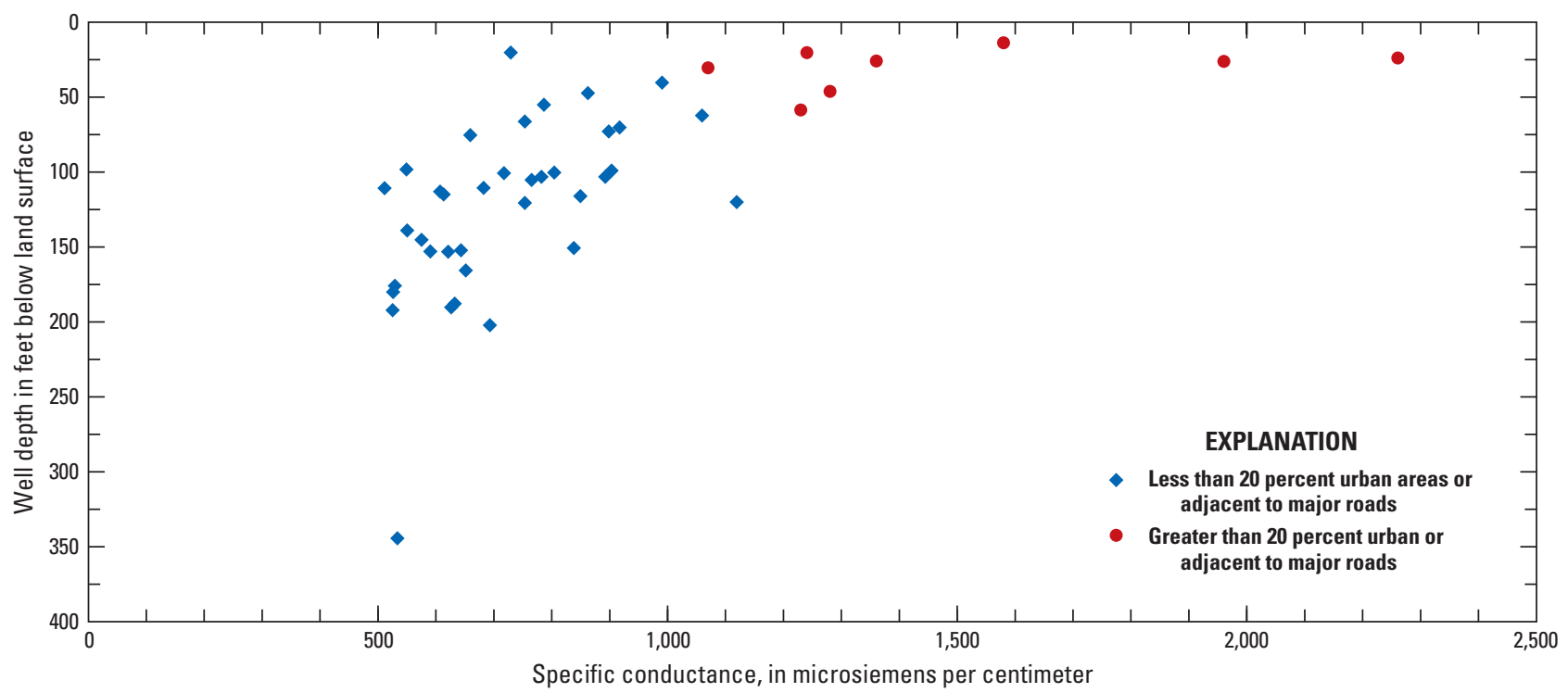

Figure 20. Well depth and specific conductance in wells from the McHenry County groundwater monitoring network, Illinois, 2010.

Calcium concentrations ranged from 34 to $176 \mathrm{mg} / \mathrm{L}$, with a median concentration of $85.9 \mathrm{mg} / \mathrm{L}$ (table 16). Magnesium concentrations ranged from 18.4 to $83.9 \mathrm{mg} / \mathrm{L}$, with a median concentration of $44.3 \mathrm{mg} / \mathrm{L}$ (table 16). Calcium and magnesium are dissolved from soils, sediments, and rock, particularly limestone and dolomite (National Ground Water Association, 2010). Calcium and magnesium cause water hardness and scale formation on pipes and other plumbing fixtures, such as boilers (National Ground Water Association, 2010). Calcium and magnesium concentrations decrease with depth, indicating that their source likely is from infiltration through carbonate-rich soils and from surface deposits or applications (fig. 21). Water-quality samples with elevated levels of calcium and magnesium were from many of the wells that also had elevated chloride, which is potentially attributed to road-salt application (fig. 22). It is important to point out that calcium chloride and magnesium chloride are common road de-icers.

Potassium concentrations ranged from 0.78 to $7.14 \mathrm{mg} / \mathrm{L}$, with a median concentration of $1.66 \mathrm{mg} / \mathrm{L}$ (table 16). The highest concentration was detected in the sample from well 1-CHE-S. Potassium commonly is found in clays, rocks, and soils, but also can be found in fertilizers (Mullaney and others, 2009). Concentrations of potassium greater than $500 \mathrm{mg} / \mathrm{L}$ usually are indicative of a road-salt source if potassium chloride is applied as the de-icer (National Ground Water Association, 2010).

Manganese concentrations ranged from 0.5 to $667 \mu \mathrm{g} / \mathrm{L}$ (table 16), with a median concentration of $29.8 \mu \mathrm{g} / \mathrm{L}$. The highest manganese concentration was detected in the sample collected from well 10-MAR-S and is above the lifetime drinking water health advisory of $300 \mu \mathrm{g} / \mathrm{L}$ (U.S. Environmental Protection Agency, 2012). This was an unusually high concentration at more than 10 times the median concentration. Manganese concentrations exceeded the SMCL of $50 \mu \mathrm{g} / \mathrm{L}$ in 30 percent of water-quality samples. Manganese concentrations detected in previous studies ranged from 1 to $180 \mu \mathrm{g} / \mathrm{L}$, with the highest concentration detected in the shallowest (49 ft below land surface) well (Nicholas and Krohelski, 1984). Elevated manganese in the shallowest wells may be from the natural occurrence in overlying soils as water infiltrates downwards and dissolves manganese under anaerobic redox conditions (Nadaska and others, 2010). 


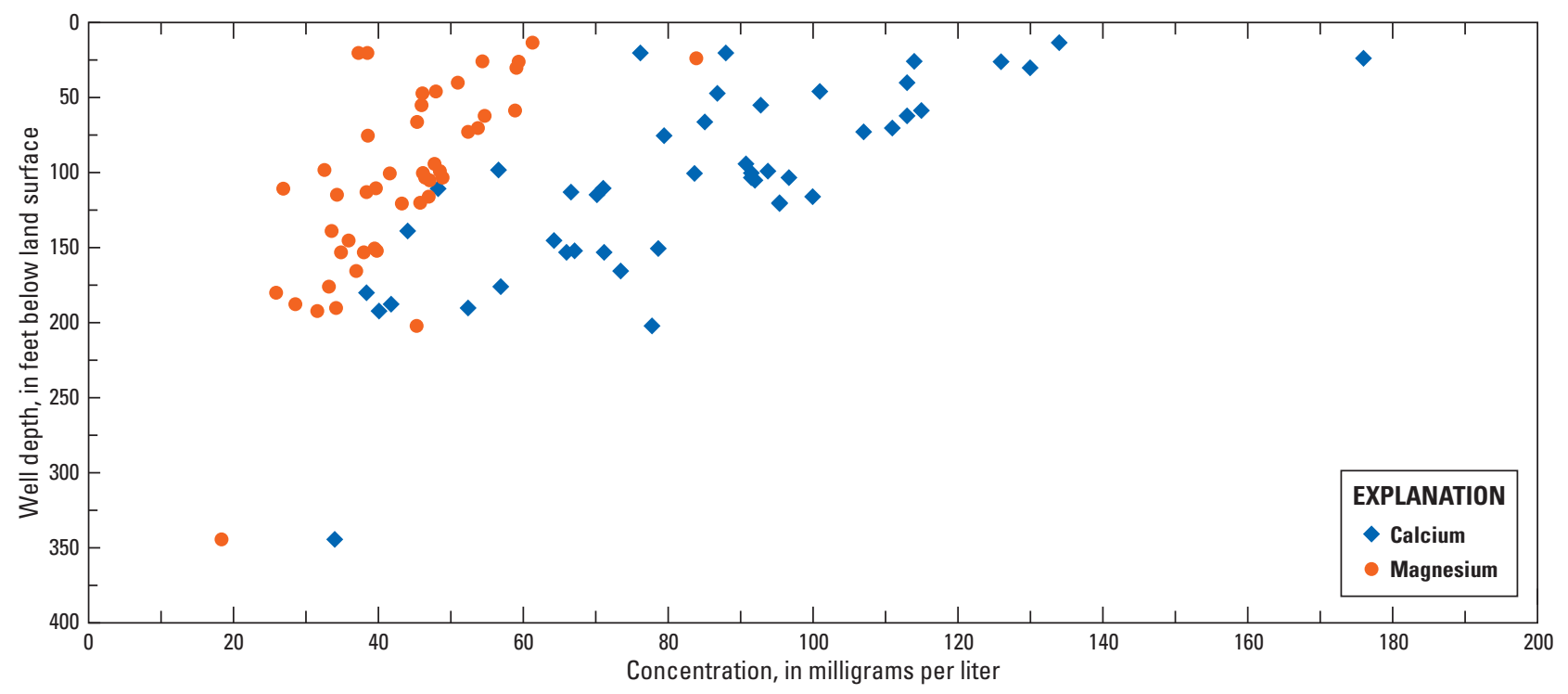

Figure 21. Relation of calcium and magnesium concentrations to well depth in water-quality samples collected from wells in the McHenry County groundwater monitoring network, Illinois, 2010.

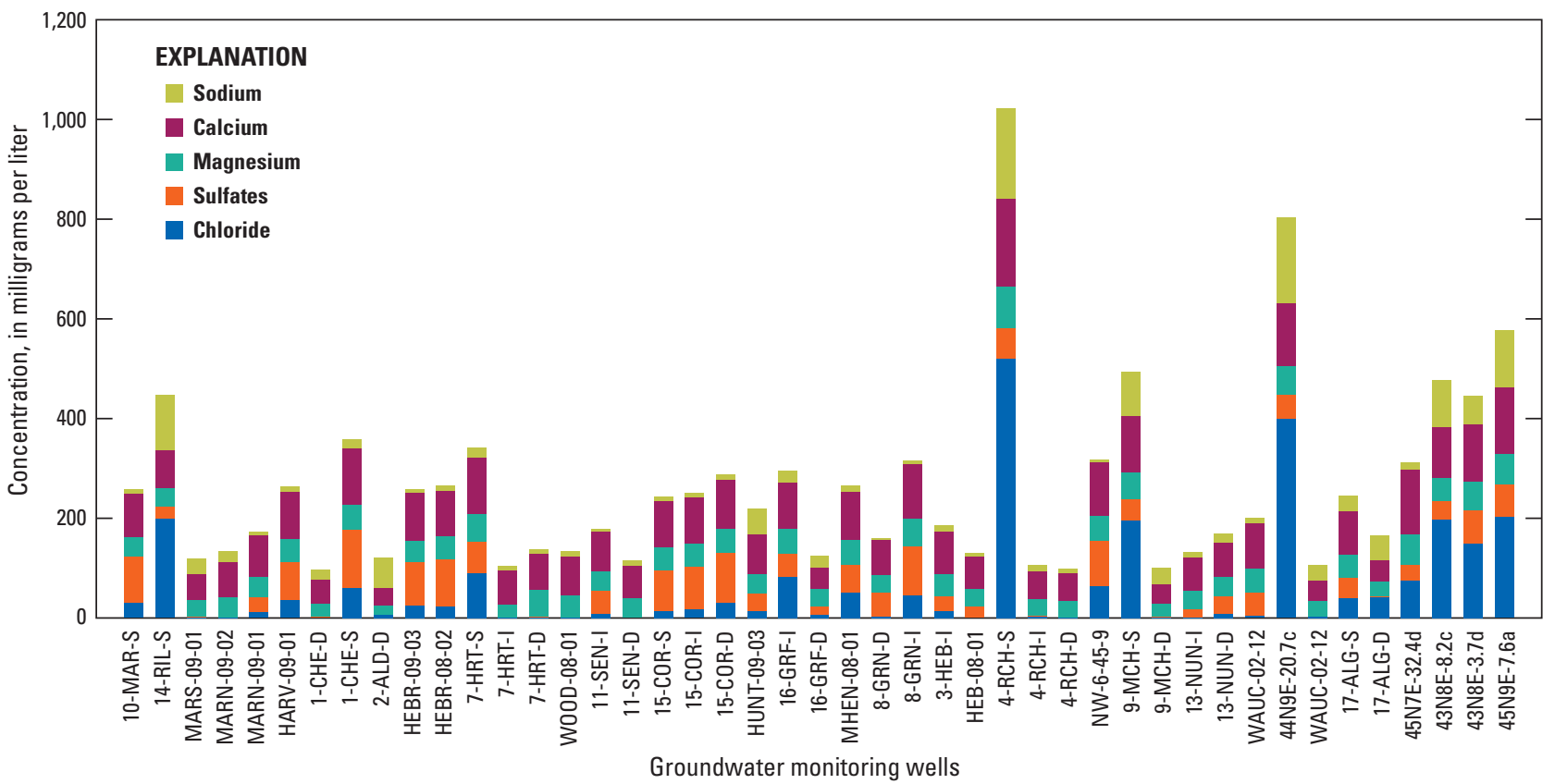

Figure 22. Distribution of major ions in water-quality samples collected from wells in the McHenry County groundwater monitoring network, Illinois, 2010. Maximum value of potassium (not shown) was 7.14 milligrams per liter. 
Chloride concentrations in McHenry County ranged from 0.5 to $521 \mathrm{mg} / \mathrm{L}$ in the 2010 sampling event, with the highest concentrations (greater than $75 \mathrm{mg} / \mathrm{L}$ ) detected in water-quality samples from wells 14-RIL-S, 16-GRF-I, 7-HRT-S, 9-MCH-S, 44N9E-20.7c, and 4-RCH-S, and the four NAWQA wells (wells 45N9E-7.6a, 45N7E-32.4d, 43N8E-3.7d, and 43N8E-8.2c) (fig. 1; table 16). Each of these wells are near major roads (as noted by the percent impervious areas) (fig. 23A) that are salted (de-iced) in winter and have total depths of less than $60 \mathrm{ft}$ below land surface (fig. 23B). Concentrations of chloride in water-quality samples from two wells in 2010 were greater than the SMCL of $250 \mathrm{mg} / \mathrm{L}$ (U.S. Environmental Protection Agency, 1992). As groundwater discharges to nearby streams, groundwater contributes to chloride in the streams and reduces the diversity in streams by selecting for salt-tolerant species (Kelly and others, 2009). The U.S. Environmental Protection Agency (1988) recommends the aquatic chronic toxicity level of $230 \mathrm{mg} / \mathrm{L}$ for chloride concentrations. Results from four of the six monitoring wells with periodic water-quality samples from 2010 to 2015 (fig. 24) showed that 85 percent (35 of 41) had concentrations greater than the chronic toxicity level, and the sample collected from one NAWQA well (44N9E-20.7c) had a concentration near the acute toxicity limit $(757 \mathrm{mg} / \mathrm{L})$.

Sodium concentrations ranged from 3.87 to $181 \mathrm{mg} / \mathrm{L}$, with a median concentration of $124 \mathrm{mg} / \mathrm{L}$. The highest concentrations of sodium $(88.3-181 \mathrm{mg} / \mathrm{L})$ were detected in four wells with the highest chloride concentration (table 16), which likely is related to the road salt application of sodium chloride. Sodium is a somewhat conservative ion, as it undergoes some cation-exchange reactions, which aid in inhibiting the movement of sodium in the groundwater (Daley and others, 2009). The health-based standard of $20 \mathrm{mg} / \mathrm{L}$ for sodium (Drinking Water Advisory) was exceeded in 37 percent of wells (17 of 46 wells; table 14).

The hardness of water-quality samples from the sand and gravel aquifers ranged from 161 to $785 \mathrm{mg} / \mathrm{L}$ (table 16 ); concentrations in this range are considered to represent hard to very hard water. Hardness is a measure of metallic ions dissolved in the water, such as calcium, magnesium, iron, and manganese. It is measured as an equivalent concentration of $\mathrm{CaCO}_{3}$ (U.S. Environmental Protection Agency, 1986). Water from the sand and gravel aquifers historically have been considered hard (greater than $150 \mathrm{mg} / \mathrm{L}$, as $\mathrm{CaCO}_{3}$ ) to very hard (greater than $300 \mathrm{mg} / \mathrm{L}$, as $\mathrm{CaCO}_{3}$ ) (Nicholas and Krohelski, 1984).
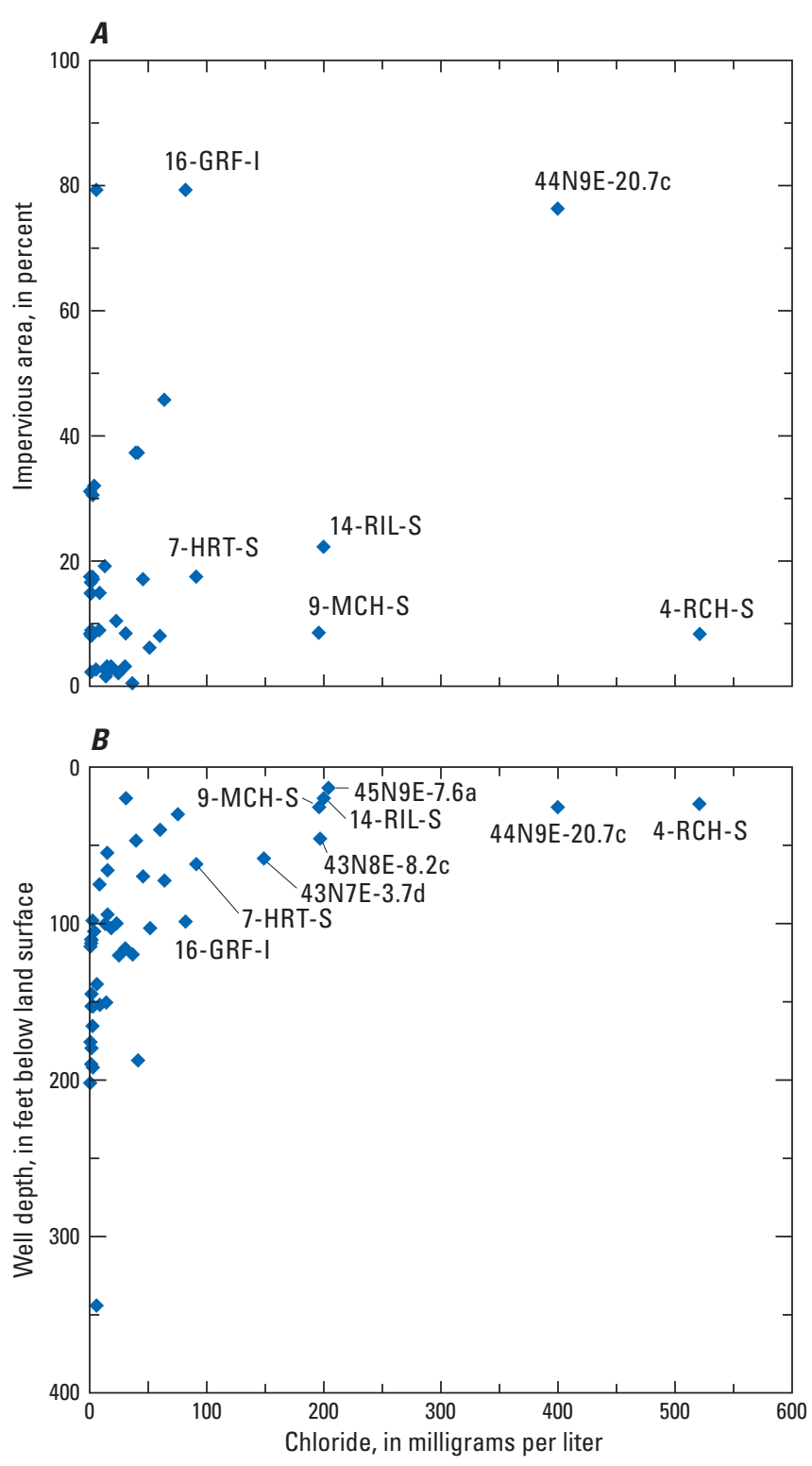

Figure 23. Chloride concentrations compared with $(A)$ impervious areas and $(B)$ well depth from wells in the McHenry County groundwater monitoring network, Illinois, 2010. 


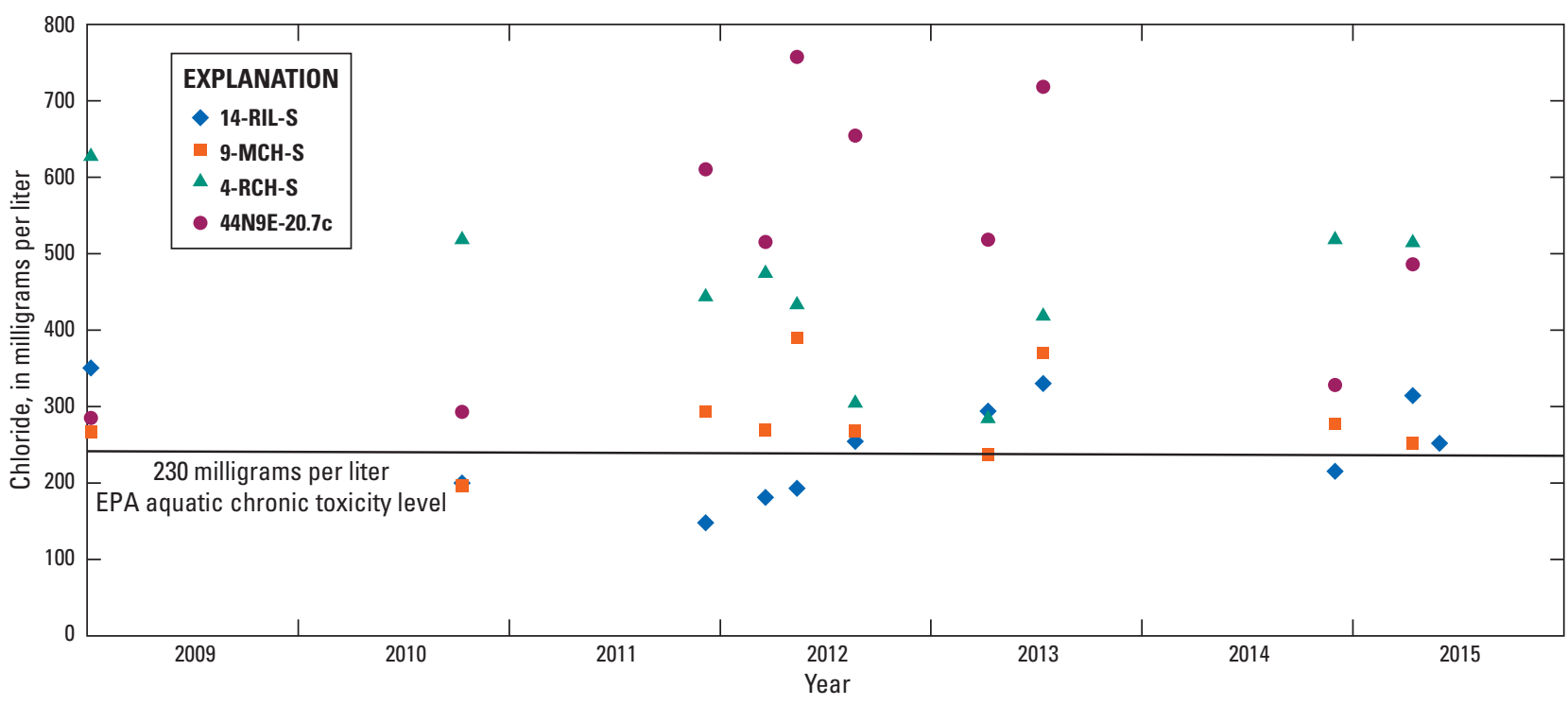

Figure 24. Chloride concentrations from periodic water-quality samples collected from selected wells in the McHenry County groundwater monitoring network, Illinois, 2009-15, and U.S. Environmental Protection Agency (EPA) aquatic toxicity level.

Field alkalinity ranged from 344 to $555 \mathrm{mg} / \mathrm{L}$ as calcium carbonate $\left(\mathrm{CaCO}_{3}\right)$ with a median value of $331 \mathrm{mg} / \mathrm{L}$ (table 16). Alkalinity was measured in the field at the time of sampling at eight monitoring wells. All other alkalinity results were obtained from laboratory analysis. The range in laboratory tested alkalinity was $270-423 \mathrm{mg} / \mathrm{L}$, with a median concentration of $331 \mathrm{mg} / \mathrm{L}$ (table 16 . Alkalinity is the capacity of water to resist changes in $\mathrm{pH}$ caused by acids, and results primarily from the presence of the bicarbonate ion $\left(\mathrm{HCO}_{3}^{-}\right.$; U.S. Environmental Protection Agency, 1986). High concentrations of alkalinity can negatively affect boilers and water heaters by causing scaling, and industrial food operations by altering taste and quality (U.S. Environmental Protection Agency, 1986). Because of these potential effects, the U.S. Environmental Protection Agency (1986) recommends water with an alkalinity range of $85-500 \mathrm{mg} / \mathrm{L}$ as $\mathrm{CaCO}_{3}$ for industry use.

Sulfate concentrations ranged from less than 0.09 to $117 \mathrm{mg} / \mathrm{L}$, with a median concentration of $44.59 \mathrm{mg} / \mathrm{L}$ (table 16). All concentrations were less than the SMCL of $250 \mathrm{mg} / \mathrm{L}$. Hydrogen sulfides $\left(\mathrm{H}_{2} \mathrm{~S}\right)$ commonly are associated with a "rotten egg" odor and can be detected by humans in air at a dilution of 0.002 parts per million (Agency for Toxic Substances and Disease Registry, 2011). Therefore, sniff tests often can determine whether there is a presence of $\mathrm{H}_{2} \mathrm{~S}$ at the time of sampling. Water-quality samples from 10 of 46 wells had detections of $\mathrm{H}_{2} \mathrm{~S}$, and almost all (90 percent) of the detections were in water-quality samples collected from deep wells (greater than $100 \mathrm{ft}$ below land surface) except well 3-HEB-I (66 ft below land surface). $\mathrm{H}_{2} \mathrm{~S}$ is common as an anaerobic degradation product of organic sulfur compounds and inorganic sulfates (Hem, 1989). Lastly, field sulfide concentrations ranged from 0 to $0.15 \mathrm{mg} / \mathrm{L}$, with a median of $0.012 \mathrm{mg} / \mathrm{L}$ (table 17). Sulfide results were used in the Redox Assignment Model to determine redox conditions relative to the TEAP described in Chapelle and others (2003).

\section{Nutrients}

Nitrogen and phosphorus are naturally abundant in the environment, but also can be added from fertilizers, animal manure, and sewage. Anthropogenic sources of nutrients increase the amount of nitrogen and phosphorus in runoff into streams and wetlands. Nitrate plus nitrite concentrations ranged from less than 0.02 to $10 \mathrm{mg} / \mathrm{L}$; however, because nitrite is not stable in typical groundwater conditions and generally is found only in low concentrations, nitrate plus nitrite is referred to hereinafter simply as "nitrate" (table 17). Nitrate concentrations greater than $2-3 \mathrm{mg} / \mathrm{L}$ either are naturally occurring or from anthropogenic sources (such as sewage, fertilizer, and landfill leachate) (Madison and Brunett, 1985; Mueller and Helsel, 1996). The relation of nitrate concentrations to well depth and to DO are shown in figure 25. 
Table 17. Nutrients from water-quality samples collected from wells in the McHenry County groundwater monitoring network and four wells from the National Water-Quality Assessment program, McHenry County, Illinois, 2010.

[Locations of monitoring wells are shown in figure 1. Dissolved organic carbon: A few selected wells were tested. Abbreviations: E, estimated; M, detect; mg/L, milligram per liter; $\mathrm{N}$, nitrogen; $\mathrm{NO}_{3}$, nitrate; $\mathrm{NO}_{2}$, nitrite; P, phosphorus; U, nondetect; USGS, U.S. Geological Survey; NA, not available; $<$, less than reporting limit; -, no data]

\begin{tabular}{|c|c|c|c|c|c|c|c|c|c|}
\hline $\begin{array}{c}\text { Monitoring } \\
\text { well }\end{array}$ & $\begin{array}{c}\text { Ammonia } \\
\text { (mg/L as N) }\end{array}$ & $\begin{array}{c}\text { Nitrate } \\
\left(\mathrm{NO}_{3}+\mathrm{NO}_{2}\right) \\
(\mathrm{mg} / \mathrm{L} \text { as } \mathrm{N})\end{array}$ & $\begin{array}{c}\text { Nitrite } \\
\text { (mg/L as N) }\end{array}$ & $\begin{array}{c}\text { Total } \\
\text { nitrogen } \\
\text { (mg/L) }\end{array}$ & $\begin{array}{c}\text { Ortho- } \\
\text { phosphate } \\
\text { (mg/L as P) }\end{array}$ & $\begin{array}{l}\text { Hydrogen } \\
\text { sulfide } \\
\text { (mg/L) }\end{array}$ & $\begin{array}{c}\text { Sulfide } \\
\text { field } \\
\text { (mg/L) }\end{array}$ & $\begin{array}{c}\text { Carbon } \\
\text { dioxide } \\
\text { (mg/L) }\end{array}$ & $\begin{array}{c}\text { Dissolved } \\
\text { organic } \\
\text { carbon } \\
\text { (mg/L) }\end{array}$ \\
\hline 14-RIL-S & $<0.010$ & 10 & 0.025 & 10.4 & 0.01 & $\mathrm{U}$ & 0.005 & 28 & - \\
\hline HUNT-09-03 & 0.763 & $<0.02$ & $<0.001$ & 0.87 & 0.045 & M & 0.012 & 29 & - \\
\hline 16-GRF-I & 0.620 & $<0.02$ & $<0.001$ & 0.81 & 0.016 & $\mathrm{U}$ & 0.002 & NA & - \\
\hline 16-GRF-D & 0.862 & $<0.02$ & $<0.001$ & 1.03 & 0.022 & M & 0.064 & 10 & - \\
\hline 17-ALG-S & 0.488 & 0.71 & 0.006 & 1.28 & 0.017 & $\mathrm{U}$ & 0.011 & 33.9 & 1 \\
\hline 17-ALG-D & 1.04 & $<0.02$ & $<0.001$ & 1.19 & 0.014 & $\mathrm{U}$ & 0.029 & 12 & - \\
\hline $43 \mathrm{~N} 8 \mathrm{E}-8.2 \mathrm{c}^{1}$ & $<0.020$ & 2.8 & 0.003 & 2.85 & 0.013 & $\mathrm{U}$ & 0.018 & 37.3 & 0.8 \\
\hline MARS-09-01 & 1.29 & $<0.02$ & $<0.001$ & 1.4 & 0.016 & $\mathrm{U}$ & 0.006 & 19 & - \\
\hline 15-COR-S & 0.249 & $<0.02$ & $<0.001$ & 0.3 & 0.037 & $\mathrm{U}$ & 0.015 & 21 & - \\
\hline 15-COR-I & 0.247 & $<0.02$ & $<0.001$ & 0.27 & 0.018 & $\mathrm{U}$ & 0.005 & 26 & - \\
\hline 15-COR-D & 0.283 & $<0.02$ & 0.001 & 0.35 & 0.033 & $\mathrm{U}$ & 0.008 & 29 & - \\
\hline $43 \mathrm{~N} 8 \mathrm{E}-3.7 \mathrm{~d}^{1}$ & 0.021 & $<0.04$ & $<0.002$ & E.06 & 0.014 & $\mathrm{U}$ & 0.007 & 46.2 & 0.7 \\
\hline 10-MAR-S & 0.020 & 0.23 & 0.013 & 0.31 & 0.007 & $\mathrm{U}$ & 0.006 & 30 & - \\
\hline WAUC-02-12 & 0.632 & $<0.02$ & $<0.001$ & 0.65 & 0.016 & M & 0.014 & 12 & - \\
\hline 11-SEN-I & 0.135 & $<0.02$ & $<0.001$ & 0.15 & 0.019 & $\mathrm{U}$ & 0.001 & 12 & - \\
\hline 11-SEN-D & 1.14 & $<0.02$ & $<0.001$ & 1.27 & 0.022 & $\mathrm{U}$ & 0.016 & 14 & - \\
\hline 44N9E-20.7c & $<0.020$ & 0.06 & 0.004 & E0.10 & 0.011 & $\mathrm{U}$ & 0.043 & 52.1 & 2.6 \\
\hline MARN-09-02 & 1.59 & $<0.02$ & $<0.001$ & 1.7 & 0.035 & $\mathrm{U}$ & 0.007 & 31 & - \\
\hline WOOD-08-01 & 1.19 & $<0.02$ & $<0.001$ & 1.24 & 0.028 & $\mathrm{U}$ & 0.004 & 29 & - \\
\hline 13-NUN-I & 0.343 & $<0.02$ & $<0.001$ & 0.36 & 0.029 & M & 0.035 & 16 & - \\
\hline 13-NUN-D & 0.261 & $<0.02$ & $<0.001$ & 0.28 & 0.022 & M & 0.15 & 17 & - \\
\hline WAUC-08-13 & 0.166 & $<0.02$ & $<0.001$ & 0.41 & 0.023 & $\mathrm{U}$ & 0.005 & 39 & - \\
\hline $45 \mathrm{~N} 7 \mathrm{E}-32.4 \mathrm{~d}^{1}$ & E0.016 & $<0.04$ & $<0.002$ & E0.07 & 0.017 & $\mathrm{U}$ & 0 & 107.2 & 0.7 \\
\hline MHEN-08-01 & 0.124 & $<0.02$ & $<0.001$ & 0.19 & 0.023 & $\mathrm{U}$ & 0.025 & 55 & - \\
\hline MARN-09-01 & 1.17 & $<0.02$ & $<0.003$ & 1.26 & 0.152 & M & 0.012 & 25 & - \\
\hline 7-HRT-S & 0.09 & $<0.02$ & 0.001 & 0.12 & 0.032 & $\mathrm{U}$ & 0.02 & 50 & - \\
\hline 7-HRT-I & 0.866 & $<0.02$ & $<0.001$ & 0.94 & 0.023 & $\mathrm{U}$ & 0.003 & 26 & - \\
\hline 7-HRT-D & 1.16 & $<0.02$ & 0.001 & 1.23 & 0.06 & $\mathrm{U}$ & 0.005 & 31 & - \\
\hline 9-MCH-S & $<0.020$ & 3.76 & $<0.002$ & 4.02 & 0.02 & $\mathrm{U}$ & 0.006 & 71.3 & 1.5 \\
\hline 9-MCH-D & 1.54 & $<0.02$ & $<0.001$ & 1.78 & 0.027 & $\mathrm{U}$ & 0.018 & 9.2 & - \\
\hline 8-GRN-I & 0.055 & $<0.02$ & $<0.001$ & 0.1 & 0.018 & $\mathrm{U}$ & - & 31 & - \\
\hline 8-GRN-D & 0.091 & $<0.02$ & $<0.001$ & 0.09 & 0.024 & $\mathrm{U}$ & 0.003 & 14 & - \\
\hline HEBR-08-02 & 0.08 & $<0.02$ & $<0.001$ & 0.1 & 0.014 & $\mathrm{U}$ & 0.003 & 28 & - \\
\hline 45 N9E-7.6a ${ }^{1}$ & E0.011 & 2.18 & 0.033 & 2.35 & 0.015 & $\mathrm{U}$ & 0.01 & 103 & 1.5 \\
\hline HARV-09-01 & 0.022 & $<0.02$ & $<0.001$ & $<0.05$ & 0.01 & $\mathrm{U}$ & 0 & 50 & - \\
\hline NW-6-45-9 & 0.019 & $<0.02$ & $<0.001$ & $<0.05$ & 0.012 & $\mathrm{U}$ & 0.008 & 36 & - \\
\hline 1-CHE-S & 0.131 & $<0.02$ & $<0.001$ & 0.22 & 0.019 & $\mathrm{U}$ & 0.002 & 57 & - \\
\hline 1-CHE-D & 1.88 & $<0.02$ & $<0.001$ & 2 & 0.081 & M & 0.026 & 13 & - \\
\hline 2-ALD-D & 0.952 & $<0.02$ & 0.001 & 1.31 & 0.034 & $\mathrm{U}$ & 0.066 & 13 & - \\
\hline HEBR-09-03 & 0.046 & $<0.02$ & $<0.001$ & 0.1 & 0.017 & $\mathrm{U}$ & 0.013 & 21 & - \\
\hline 4-RCH-S & 0.567 & 0.09 & 0.003 & 0.71 & 0.038 & $\mathrm{U}$ & 0.019 & 37.1 & 1.6 \\
\hline 4-RCH-I & 0.928 & $<0.02$ & $<0.001$ & 1 & 0.075 & $\mathrm{U}$ & 0.015 & 14 & - \\
\hline 4-RCH-D & 0.819 & $<0.02$ & 0.001 & 0.87 & 0.034 & $\mathrm{U}$ & 0.042 & 15 & - \\
\hline HEBR-08-01 & 0.421 & $<0.02$ & 0.001 & 0.44 & 0.04 & $\mathrm{M}$ & 0.028 & 10 & - \\
\hline 3-HEB-I & 1.28 & $<0.02$ & 0.001 & 1.38 & 0.026 & M & 0.051 & 21 & - \\
\hline 3-HEB-D & 1.17 & $<0.02$ & 0.001 & 1.26 & 0.034 & M & 0.055 & 21 & - \\
\hline
\end{tabular}

${ }^{1}$ USGS National Water-Quality Assessment program monitoring wells were included in 2010 sampling period, but were not equipped with real-time instrumentation. 

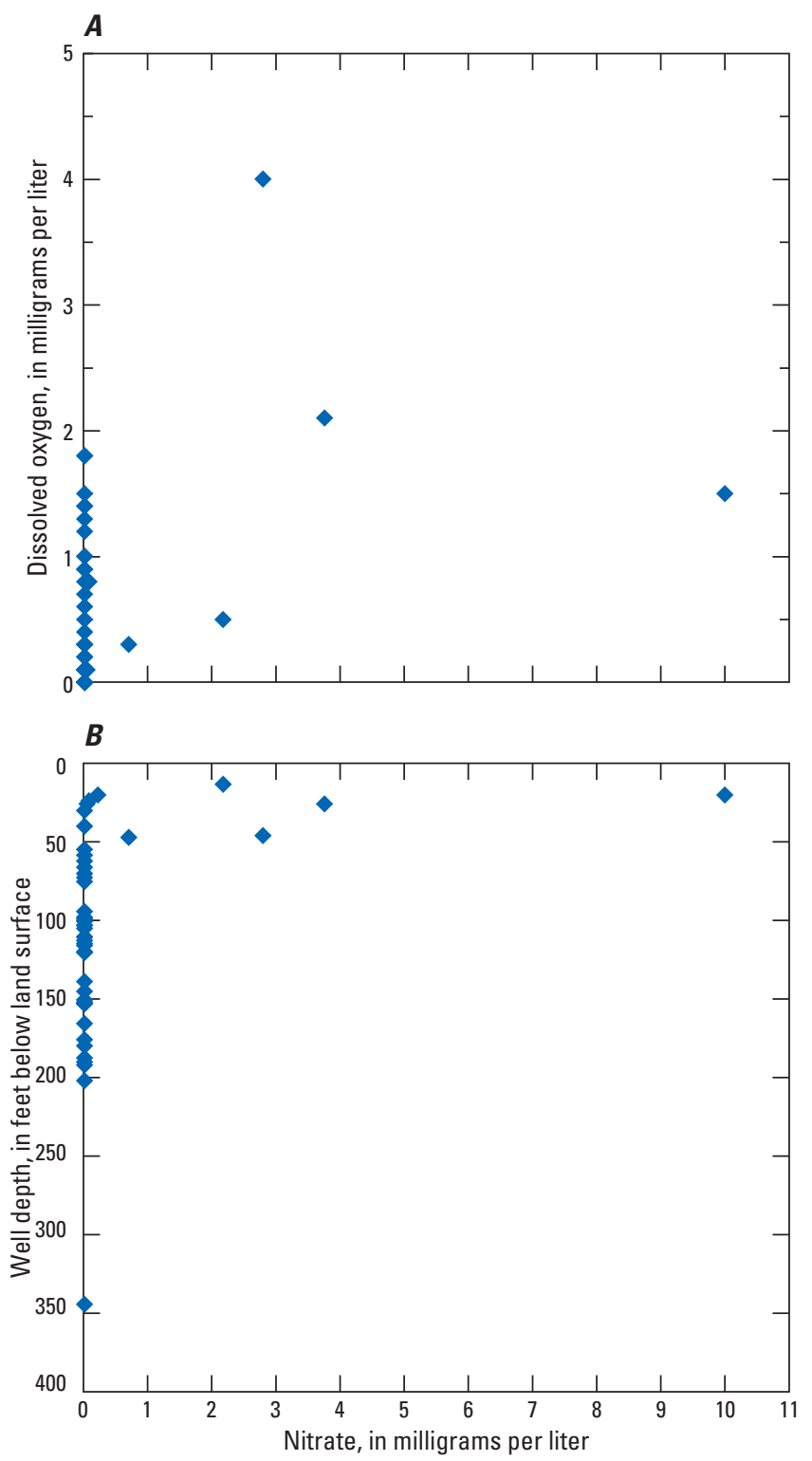

Figure 25. Relations of nitrate concentrations to $(A)$ dissolved-oxygen concentrations and $(B)$ well depth in water-quality samples collected from wells in the McHenry County groundwater monitoring network, Illinois, 2010.

Three wells (less than $50 \mathrm{ft}$ ) (43N8E-8.2c, 9-MCH-S, and 45N9E-7.6a) had concentrations between 2 and $4 \mathrm{mg} / \mathrm{L}$, and one well (14-RIL-S) was at the EPA MCL of $10 \mathrm{mg} / \mathrm{L}$ (table 17); therefore, 2 percent of sampled wells exceeded the MCL. The highest nitrate concentration was detected in a sample collected from a 20-ft-deep well near the edge of a field of cultivated crops, indicating an anthropogenic source (fertilizers). Elevated levels of nitrates above $10 \mathrm{mg} / \mathrm{L}$ can cause methemoglobinemia (blue-baby syndrome) in infants. Elevated levels of nitrogen and phosphorus also can cause eutrophication (depletion of food and oxygen sources in a stream), which results in fish and plant mortality (U.S. Geological Survey, 1999). Water-quality samples from two wells (45N9E-7.6a and 17-ALG-S) with low concentrations of DO (less than $0.6 \mathrm{mg} / \mathrm{L}$ ) had slightly higher concentrations of nitrate (about $0.7-2.2 \mathrm{mg} / \mathrm{L}$ ), indicating that the nitrate in these water-quality samples also might be anthropogenic. A similar range in nitrate concentration $(0.047-12.5 \mathrm{mg} / \mathrm{L})$ was detected in a previous study, which focused on the Upper Illinois River Basin (Morrow, 2002). Of the 43 monitoring wells sampled in that study, two wells had concentrations of nitrate near or greater than the EPA MCL; both of those wells were in McHenry County. A study by Nicholas and Krohelski (1984) also determined a similar range for nitrates (less than $0.010-11 \mathrm{mg} / \mathrm{L}$ ).

Ammonia concentrations in water-quality samples from the MCGMN wells ranged from less than 0.010 to $1.88 \mathrm{mg} / \mathrm{L}$, with a median concentration of $0.52 \mathrm{mg} / \mathrm{L}$ (table 17). Ammonia is the reduced form of nitrogen or nitrates from denitrification processes. Naturally occurring concentrations of ammonia typically are less than $0.1 \mathrm{mg} / \mathrm{L}$, primarily because of its instability as ammonia (Burkart and Stoner, 2008). Values greater than $1 \mathrm{mg} / \mathrm{L}$ may indicate that additional sources of ammonia (fertilizers, septic, and sewage) are entering the groundwater at these monitoring well locations. The higher concentrations (greater than $1 \mathrm{mg} / \mathrm{L}$ ) primarily were detected in water-quality samples from deeper wells (greater than about $100 \mathrm{ft}$ below land surface) (fig. 26).

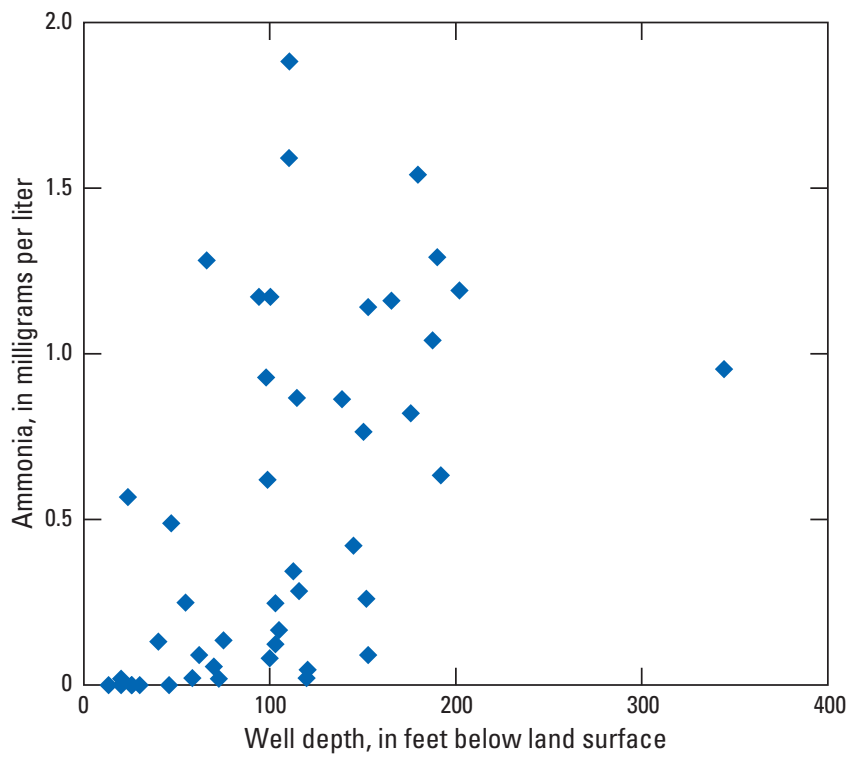

Figure 26. Ammonia concentrations and well depths from water-quality samples collected from wells in the McHenry County groundwater monitoring network, Illinois, 2010. 
Phosphate (orthophosphate) concentrations ranged from 0.007 to $0.152 \mathrm{mg} / \mathrm{L}$, with a median concentration of $0.022 \mathrm{mg} / \mathrm{L}$ (table 17). The highest concentration was detected in the sample from well MARN-09-01. This concentration was one order of magnitude greater than water-quality samples collected from all other wells. Possible sources of the phosphate could include a former septic field or agricultural practices. The septic field is presumed from inspection of historical imagery (1988-2005) of this well location available from Google Earth ${ }^{\mathrm{TM}}$ (Google, 2015).

The dissolved organic carbon concentrations were above the detection limit (0.66) in all eight of the select network wells, ranging from 0.7 to $2.6 \mathrm{mg} / \mathrm{L}$ (table 17). Dissolved organic carbon is a measure of the amount of organic matter that can pass through a filter (commonly 0.45 microns). Organic carbon is derived from decaying plant matter, but also can be from agricultural applications (Fujii and others, 1998). Dissolved organic carbon can be a source of food for microbial processes that encourages reductive biodegradation of organics, such as chlorinated hydrocarbons, but also can encourage the dissolution of some inorganics such as metals (Chapelle and others, 2003).

\section{Dissolved Gases}

Dissolved carbon dioxide concentrations ranged from 9.2 to $107.2 \mathrm{mg} / \mathrm{L}$, with a median concentration of $28 \mathrm{mg} / \mathrm{L}$. The water-quality samples with the highest concentrations of carbon dioxide were from the shallowest wells in the network (less than $25 \mathrm{ft}$ below land surface) (table 17). Additional dissolved gases were analyzed at eight monitoring wells (table 18). Dissolved methane was detected at one of the eight wells (17-ALG-S; fig. 1) at a concentration of $0.59 \mathrm{mg} / \mathrm{L}$. The presence of methane at well 17-ALG-S could be because of microbial degradation in organic-rich glacial sediments (Chapelle and others, 2003). Argon concentrations ranged from 0.67 to $0.85 \mu \mathrm{g} / \mathrm{L}$, with a median concentration of $0.72 \mathrm{mg} / \mathrm{L}$ (table 18 ). Nitrogen gas ranged from 20.28 to $26.86 \mathrm{mg} / \mathrm{L}$ (table 18). Argon and nitrogen gas are used to analyze the age of groundwater and to trace the sources of groundwater recharge; however, this type of analysis was beyond the scope of this study.

\section{Metals and Trace Elements}

Arsenic is naturally occurring in bedrock material and shallow glacial deposits in Illinois and may be released to groundwater by bedrock erosion or changing redox conditions in aquifer systems (Hem, 1989; Illinois State Water Survey, 2002). Arsenic was detected in water-quality samples from all MCGMN wells, with concentrations ranging from 0.15 to $62 \mu \mathrm{g} / \mathrm{L}$ (table 19). High concentrations (greater than $16 \mu \mathrm{g} / \mathrm{L}$ ) were detected at wells 1-CHE-D, HUNT-09-03, 17-ALG-D, 7-HRT-I, 4-RCH-D, 3-HEB-I, and MARS-09-01, where well depths were greater than $110 \mathrm{ft}$ below land surface. Ingestion
Table 18. Dissolved gases from selected monitoring wells in comprehensive water-quality sampling in McHenry County, Illinois, 2010.

[Locations of monitoring wells are shown in figure 1. Bold value indicates detection above reporting limit. Abbreviations: $\mu \mathrm{g} / \mathrm{L}$, microgram per liter; $\mathrm{mg} / \mathrm{L}$, milligram per liter; USGS, U.S. Geological Survey; <, less than reporting limit]

\begin{tabular}{lccl}
\hline $\begin{array}{c}\text { Monitoring } \\
\text { well }\end{array}$ & $\begin{array}{c}\text { Methane } \\
\text { (mg/L) }\end{array}$ & $\begin{array}{c}\text { Nitrogen } \\
\text { gas, water } \\
(\mathbf{m g} / \mathbf{L})\end{array}$ & $\begin{array}{c}\text { Argon } \\
(\boldsymbol{\mu g} / \mathbf{L})\end{array}$ \\
\hline 17-ALG-S & $\mathbf{0 . 5 9}$ & 26.86 & 0.77 \\
43N8E-8.2c ${ }^{1}$ & & 20.28 & 0.67 \\
43N8E-3.7d ${ }^{1}$ & $<0.005$ & 23.24 & 0.7 \\
44N9E-20.7c & & 22.62 & 0.69 \\
45N7E-32.4d & & 22.54 & 0.85 \\
9-MCH-S & & 21.29 & 0.74 \\
45N9E-7.6a & $<0.005$ & 23.74 & 0.74 \\
4-RCH-S & $<0.005$ & 23.4 & 0.7 \\
\hline
\end{tabular}

${ }^{1}$ USGS National Water-Quality Assessment program monitoring wells were included in 2010 sampling period, but were not equipped with real-time instrumentation.

of high amounts of arsenic (acute or chronic) has been linked to cancer, and effects on the cardiovascular, pulmonary, neurological, and endocrine system (U.S. Environmental Protection Agency, 2007). The established MCL for public drinking water is $10 \mu \mathrm{g} / \mathrm{L}$ (U.S. Environmental Protection Agency, 2012). Sample concentrations for 22 percent (11 of 46) of the wells were greater than this regulatory limit. Drinking-water sources tapped by residential supply wells could be at risk where those wells are located near monitoring wells with elevated arsenic levels (fig, 27). Effective treatment methods for supply wells are available, including filtration, ion-exchange systems, and reverse-osmosis systems that can be used to reduce arsenic levels in drinking water (Thomas and Eckberg, 2015).

Aluminum concentrations ranged from 1.7 to $38.9 \mu \mathrm{g} / \mathrm{L}$, with the highest concentration detected at well 13-NUN-D (fig. 1, table 19). All water-quality samples had concentrations less than the SMCL of 50-200 $\mu \mathrm{g} / \mathrm{L}$ (U.S. Environmental Protection Agency, 1992). Barium concentrations ranged from 40 to $239 \mu \mathrm{g} / \mathrm{L}$, with a median concentration of $88 \mu \mathrm{g} / \mathrm{L}$ (table 19). No concentrations were greater than the MCL of $2,000 \mu \mathrm{g} / \mathrm{L}$.

Lead was detected at five well sites (14-RIL-S, 45N7E-32.4d, 7-HRT-S, 45N9E-7.6a, NW-6-45-9), with confirmed concentrations ranging from 0.02 to $0.07 \mu \mathrm{g} / \mathrm{L}$; estimated concentrations of $0.02 \mu \mathrm{g} / \mathrm{L}$ were detected at two locations, 44N9E-20.7c and 9-MCH-S (fig. 1, table 19). The highest detected concentration of lead was at well NW-6-45-9. Lead can delay physical or mental development in children; the treatment technique-based action limit for public drinking water is $15 \mu \mathrm{g} / \mathrm{L}$ (U.S. Environmental Protection Agency, 2012). All detections were below this action limit. 
Table 19. Metals from comprehensive water-quality samples collected from wells in the McHenry County groundwater monitoring network, Illinois, 2010.

[Locations of monitoring wells are shown in figure 1. Abbreviations: E, estimated (considered a detection only if equal to or greater than the reporting limit); $\mu \mathrm{gL}$, microgram per liter; mg/L, milligram per liter; USGS, U.S. Geological Survey; <, less than reporting limit]

\begin{tabular}{|c|c|c|c|c|c|c|c|c|}
\hline $\begin{array}{l}\text { Monitoring } \\
\text { well }\end{array}$ & $\begin{array}{l}\text { Aluminum } \\
\qquad(\mu \mathrm{g} / \mathrm{L})\end{array}$ & $\begin{array}{c}\text { Barium } \\
\text { ( } \mu \mathrm{g} / \mathrm{L})\end{array}$ & $\begin{array}{c}\text { Beryllium } \\
\text { ( } \mu \mathrm{g} / \mathrm{L})\end{array}$ & $\begin{array}{c}\text { Cadmium } \\
(\mu \mathrm{g} / \mathrm{L})\end{array}$ & $\begin{array}{l}\text { Chromium } \\
(\mu \mathrm{g} / \mathrm{L})\end{array}$ & $\begin{array}{c}\text { Iron (II), } \\
\text { field } \\
\text { (mg/L) }\end{array}$ & $\begin{array}{c}\text { Total iron, } \\
\text { laboratory } \\
(\mu \mathrm{g} / \mathrm{L})\end{array}$ & $\begin{array}{l}\text { Lead } \\
(\mu \mathrm{g} / \mathrm{L})\end{array}$ \\
\hline 14-RIL-S & $<1.7$ & 102 & $<0.01$ & $<0.02$ & 0.42 & 0 & 8 & 0.04 \\
\hline HUNT-09-03 & $<1.7$ & 90 & $<0.01$ & $<0.02$ & 0.12 & 2.08 & 1,920 & $<0.01$ \\
\hline 16-GRF-I & $<1.7$ & 208 & $<0.01$ & $<0.02$ & 0.11 & 1.24 & 2,350 & $<0.01$ \\
\hline 16-GRF-D & $<1.7$ & 116 & $<0.01$ & $<0.02$ & $<0.06$ & 0.65 & 608 & $<0.01$ \\
\hline 17-ALG-S & E1.9 & 120 & $<0.01$ & $<0.02$ & 0.36 & 0.95 & 902 & $<0.03$ \\
\hline 17-ALG-D & 3.4 & 114 & 0.01 & $<0.02$ & 0.08 & 0.59 & 716 & $<0.01$ \\
\hline $43 \mathrm{~N} 8 \mathrm{E}-8.2 \mathrm{c}^{1}$ & E2.7 & 47 & $<0.01$ & E0.01 & 0.76 & 0.17 & 7 & $<0.03$ \\
\hline MARS-09-01 & 2.5 & 133 & $<0.01$ & 0.06 & 0.25 & 0.77 & 733 & $<0.01$ \\
\hline 15-COR-S & 1.7 & 142 & $<0.01$ & $<0.02$ & 0.08 & 2.57 & 2,490 & $<0.01$ \\
\hline 15-COR-I & $<1.7$ & 141 & $<0.01$ & $<0.02$ & $<0.06$ & 0.9 & 2,720 & $<0.01$ \\
\hline 15-COR-D & 1.8 & 158 & 0.01 & $<0.02$ & 0.07 & 2.81 & 3,450 & $<0.01$ \\
\hline $43 \mathrm{~N} 8 \mathrm{E}-3.7 \mathrm{~d}^{1}$ & $<3.4$ & 89 & $<0.01$ & E0.01 & 0.22 & 1.8 & 1,480 & $<0.03$ \\
\hline 10-MAR-S & $<1.7$ & 59 & $<0.01$ & $<0.02$ & 0.31 & 0.17 & 106 & $<0.01$ \\
\hline WAUC-02-12 & 5.2 & 100 & 0.01 & $<0.02$ & 0.17 & 0.69 & 581 & $<0.01$ \\
\hline 11-SEN-I & $<1.7$ & 80 & $<0.01$ & $<0.02$ & 0.07 & 1.63 & 1,550 & $<0.01$ \\
\hline 11-SEN-D & 2.1 & 86 & $<0.01$ & $<0.02$ & 0.1 & 1.07 & 966 & $<0.01$ \\
\hline 44N9E-20.7c & 5.6 & 118 & $<0.01$ & 0.03 & 2.3 & 0.09 & 17 & E.02 \\
\hline MARN-09-02 & $<1.7$ & 144 & $<0.01$ & $<0.02$ & 0.25 & 1.26 & 1,750 & $<0.01$ \\
\hline WOOD-08-01 & $<1.7$ & 68 & $<0.01$ & $<0.02$ & 0.36 & 0.85 & 800 & $<0.01$ \\
\hline 13-NUN-I & 2.2 & 114 & $<0.01$ & $<0.02$ & 0.49 & 1.74 & 1,630 & $<0.01$ \\
\hline 13-NUN-D & 38.9 & 75 & $<0.01$ & 0.02 & 0.24 & 0.72 & 683 & $<0.01$ \\
\hline WAUC-08-13 & $<1.7$ & 95 & 0.01 & $<0.02$ & 0.12 & 1.26 & 1,210 & $<0.01$ \\
\hline $45 \mathrm{~N} 7 \mathrm{E}-32.4 \mathrm{~d}^{1}$ & $<3.4$ & 63 & $<0.01$ & 0.03 & 0.46 & 0.09 & 9 & 0.04 \\
\hline MHEN-08-01 & $<1.7$ & 80 & $<0.01$ & $<0.02$ & 0.22 & 2.23 & 2,040 & $<0.01$ \\
\hline MARN-09-01 & $<1.7$ & 65 & $<0.01$ & $<0.02$ & 0.25 & 3.09 & 3,080 & $<0.01$ \\
\hline 7-HRT-S & $<1.7$ & 80 & $<0.01$ & $<0.02$ & 0.21 & 2.43 & 2,280 & 0.02 \\
\hline 7-HRT-I & 2.1 & 56 & $<0.01$ & $<0.02$ & 0.27 & 2.77 & 2,680 & $<0.01$ \\
\hline 7-HRT-D & $<1.7$ & 48 & $<0.01$ & $<0.02$ & 0.24 & 2.28 & 2,100 & $<0.01$ \\
\hline 9-MCH-S & E2.3 & 90 & $<0.01$ & E0.02 & 0.61 & 0.01 & E5 & E.02 \\
\hline 9-MCH-D & $<1.7$ & 112 & 0.01 & 0.04 & 0.11 & 1.53 & 2,170 & $<0.01$ \\
\hline 8-GRN-I & $<1.7$ & 84 & $<0.01$ & $<0.02$ & 0.08 & 1.84 & 1,750 & $<0.01$ \\
\hline 8-GRN-D & $<1.7$ & 40 & $<0.01$ & $<0.02$ & $<0.06$ & 1.03 & 992 & $<0.01$ \\
\hline HEBR-08-02 & $<1.7$ & 116 & $<0.01$ & $<0.02$ & 0.1 & 0.81 & 728 & $<0.01$ \\
\hline $45 \mathrm{~N} 9 \mathrm{E}-7.6 \mathrm{a}^{1}$ & $<3.4$ & 83 & $<0.01$ & 0.04 & 0.48 & 0.29 & $<6$ & 0.04 \\
\hline HARV-09-01 & $<1.7$ & 67 & $<0.01$ & $<0.02$ & 0.09 & 0.94 & 805 & $<0.01$ \\
\hline NW-6-45-9 & $<1.7$ & 45 & $<0.01$ & $<0.02$ & $<0.06$ & 1.44 & 1,360 & 0.07 \\
\hline 1-CHE-S & $<1.7$ & 193 & $<0.01$ & $<0.02$ & 0.19 & 1.81 & 1,750 & $<0.01$ \\
\hline 1-CHE-D & 3.7 & 92 & $<0.01$ & $<0.02$ & 0.26 & 1.38 & 1,260 & $<0.01$ \\
\hline 2-ALD-D & 4.1 & 64 & 0.01 & 0.05 & 0.33 & 0.87 & 788 & $<0.01$ \\
\hline HEBR-09-03 & $<1.7$ & 53 & $<0.01$ & $<0.02$ & 0.27 & 1.52 & 1,690 & $<0.01$ \\
\hline 4-RCH-S & $<3.4$ & 239 & $<0.01$ & $<0.02$ & 0.37 & 1.53 & 2,120 & $<0.03$ \\
\hline 4-RCH-I & $<1.7$ & 90 & $<0.01$ & $<0.02$ & 0.27 & 1.66 & 1,740 & $<0.01$ \\
\hline 4-RCH-D & 2.7 & 53 & $<0.01$ & $<0.02$ & 0.32 & 1.2 & 1,120 & $<0.01$ \\
\hline HEBR-08-01 & $<1.7$ & 62 & $<0.01$ & $<0.02$ & 0.44 & 1.57 & 1,500 & $<0.01$ \\
\hline 3-HEB-I & 2.1 & 87 & $<0.01$ & $<0.02$ & 0.4 & 1.94 & 1,880 & $<0.01$ \\
\hline 3-HEB-D & 2.3 & 75 & $<0.01$ & $<0.02$ & 0.54 & 1.87 & 1,740 & $<0.01$ \\
\hline
\end{tabular}


Table 19. Metals from comprehensive water-quality samples collected from wells in the McHenry County groundwater monitoring network, Illinois, 2010.-Continued

\begin{tabular}{|c|c|c|c|c|c|c|c|c|}
\hline $\begin{array}{c}\text { Monitoring } \\
\text { well }\end{array}$ & $\begin{array}{l}\text { Molybdenum } \\
\text { ( } \mu \mathrm{g} / \mathrm{L})\end{array}$ & $\begin{array}{c}\text { Nickel } \\
\text { ( } \mu \mathrm{g} / \mathrm{L} \text { ) }\end{array}$ & $\begin{array}{l}\text { Silver } \\
(\mu \mathrm{g} / \mathrm{L})\end{array}$ & $\begin{array}{l}\text { Zinc } \\
(\mu \mathrm{g} / \mathrm{L})\end{array}$ & $\begin{array}{c}\text { Antimony } \\
(\mu \mathrm{g} / \mathrm{L})\end{array}$ & $\begin{array}{c}\text { Arsenic } \\
\text { ( } \mu \mathrm{g} / \mathrm{L})\end{array}$ & $\begin{array}{c}\text { Selenium, } \\
(\mu \mathrm{g} / \mathrm{L})\end{array}$ & $\begin{array}{c}\text { Uranium, wf } \\
(\mu \mathrm{g} / \mathrm{L})\end{array}$ \\
\hline 14-RIL-S & 0.64 & 1 & 0.08 & $<1.4$ & 0.06 & 0.26 & 0.13 & 0.48 \\
\hline HUNT-09-03 & 8.62 & 1.3 & $<0.01$ & $<1.4$ & $<0.03$ & 17.4 & $<0.03$ & 0.14 \\
\hline 16-GRF-I & 2.21 & 0.43 & $<0.01$ & $<1.4$ & 0.04 & 0.42 & 0.03 & 0.05 \\
\hline 16-GRF-D & 1.59 & 0.17 & 0.01 & $<1.4$ & $<0.03$ & 0.21 & $<0.03$ & 0.01 \\
\hline 17-ALG-S & 3.73 & 0.72 & $<0.01$ & $<2.8$ & 0.07 & 0.35 & 0.05 & 1.35 \\
\hline 17-ALG-D & 5.86 & 0.97 & $<0.01$ & $<1.4$ & 0.06 & 16.1 & $<0.03$ & 0.04 \\
\hline $43 \mathrm{~N} 8 \mathrm{E}-8.2 \mathrm{c}^{1}$ & 0.39 & 2.2 & $<0.01$ & $<2.8$ & E0.03 & 0.68 & 0.49 & 0.44 \\
\hline MARS-09-01 & 33.8 & 0.73 & $<0.01$ & $<1.4$ & 0.05 & 20.1 & $<0.03$ & 0.24 \\
\hline 15-COR-S & 1.95 & 0.32 & $<0.01$ & $<1.4$ & 0.05 & 0.6 & $<0.03$ & 0.06 \\
\hline 15-COR-I & 1.8 & 0.5 & $<0.01$ & $<1.4$ & $<0.03$ & 0.82 & $<0.03$ & 0.05 \\
\hline 15-COR-D & 2.29 & 0.27 & $<0.01$ & $<1.4$ & $<0.03$ & 0.39 & $<0.03$ & 0.02 \\
\hline $43 \mathrm{~N} 8 \mathrm{E}-3.7 \mathrm{~d}^{1}$ & 2.03 & 1.8 & $<0.01$ & $<2.8$ & $<0.05$ & 0.81 & E0.04 & 0.33 \\
\hline 10-MAR-S & 2.08 & 2.2 & $<0.01$ & $<1.4$ & 0.38 & 0.96 & 0.1 & 8.04 \\
\hline WAUC-02-12 & 2.74 & 0.36 & 0.01 & $<1.4$ & $<0.03$ & 0.59 & $<0.03$ & 0.01 \\
\hline 11-SEN-I & 1.27 & 0.27 & $<0.01$ & $<1.4$ & 0.03 & 0.53 & $<0.03$ & 0.09 \\
\hline 11-SEN-D & 1.15 & 0.13 & $<0.01$ & $<1.4$ & $<0.03$ & 3.3 & $<0.03$ & 0.01 \\
\hline 44N9E-20.7c & 2.46 & 9.3 & $<0.01$ & $\mathrm{E} 1.8$ & 0.23 & 1 & 0.29 & 1.8 \\
\hline MARN-09-02 & 4.15 & 0.42 & $<0.01$ & $<1.4$ & $<0.03$ & 11.9 & $<0.03$ & 0.02 \\
\hline WOOD-08-01 & 1.67 & 0.42 & $<0.01$ & $<1.4$ & $<0.03$ & 1.4 & $<0.03$ & 0.08 \\
\hline 13-NUN-I & 1.43 & 0.28 & $<0.01$ & $<1.4$ & 0.08 & 0.69 & $<0.03$ & 0.05 \\
\hline 13-NUN-D & 6.77 & 0.28 & 0.02 & $<1.4$ & $<0.03$ & 0.37 & $<0.03$ & 0.15 \\
\hline WAUC-08-13 & 0.5 & 0.44 & $<0.01$ & $<1.4$ & 0.03 & 0.98 & $<0.03$ & 0.15 \\
\hline $45 N 7 E-32.4 d^{1}$ & 2.08 & 4.4 & $<0.01$ & 3.1 & E.05 & 0.15 & 0.05 & 3.38 \\
\hline MHEN-08-01 & 1.24 & 0.55 & $<0.01$ & $<1.4$ & $<0.03$ & 0.34 & $<0.03$ & 0.09 \\
\hline MARN-09-01 & 1.27 & 0.26 & $<0.01$ & $<1.4$ & $<0.03$ & 9.4 & $<0.03$ & 0.03 \\
\hline 7-HRT-S & 2.74 & 0.44 & $<0.01$ & $<1.4$ & 0.03 & 0.88 & $<0.03$ & 0.32 \\
\hline 7-HRT-I & 1.77 & 0.72 & $<0.01$ & $<1.4$ & $<0.03$ & 18 & $<0.03$ & 0.05 \\
\hline 7-HRT-D & 1.53 & 0.35 & $<0.01$ & $<1.4$ & $<0.03$ & 12.2 & $<0.03$ & 0.01 \\
\hline 9-MCH-S & 0.77 & 1.4 & $<0.01$ & $<2.8$ & E.03 & 0.22 & 0.37 & 0.7 \\
\hline 9-MCH-D & 12.4 & 0.23 & $<0.01$ & $<1.4$ & $<0.03$ & 4.3 & $<0.03$ & 0.03 \\
\hline 8-GRN-I & 2.61 & 0.53 & $<0.01$ & $<1.4$ & 0.04 & 0.89 & $<0.03$ & 0.28 \\
\hline 8-GRN-D & 2.75 & 0.27 & $<0.01$ & $<1.4$ & 0.08 & 0.93 & $<0.03$ & 0.19 \\
\hline HEBR-08-02 & 1.58 & 0.75 & $<0.01$ & $<1.4$ & 0.03 & 1.8 & $<0.03$ & 0.54 \\
\hline 45 N9E-7.6a ${ }^{1}$ & 1.28 & 9.3 & $<0.01$ & $<2.8$ & 0.07 & 0.75 & 0.11 & 0.73 \\
\hline HARV-09-01 & 3.18 & 0.66 & $<0.01$ & $<1.4$ & 0.03 & 0.74 & $<0.03$ & 0.71 \\
\hline NW-6-45-9 & 2 & 0.65 & $<0.01$ & 7.6 & $<0.03$ & 0.7 & $<0.03$ & 0.56 \\
\hline 1-CHE-S & 0.85 & 0.92 & $<0.01$ & $<1.4$ & $<0.03$ & 0.38 & $<0.03$ & 1.54 \\
\hline 1-CHE-D & 8.01 & 0.36 & $<0.01$ & $<1.4$ & $<0.03$ & 62.0 & $<0.03$ & 0.01 \\
\hline 2-ALD-D & 14.3 & 0.62 & $<0.01$ & $<1.4$ & $<0.03$ & 0.63 & $<0.03$ & 0.01 \\
\hline HEBR-09-03 & 1.01 & 0.39 & $<0.01$ & 1.7 & 0.04 & 0.54 & $<0.03$ & 0.1 \\
\hline 4-RCH-S & 2.61 & 0.84 & $<0.01$ & $<2.8$ & E0.03 & 0.62 & 0.04 & 0.37 \\
\hline 4-RCH-I & 4.66 & 0.64 & $<0.01$ & $<1.4$ & $<0.03$ & 13.5 & $<0.03$ & 0.05 \\
\hline 4-RCH-D & 1.33 & 0.39 & $<0.01$ & $<1.4$ & 0.07 & 16.2 & $<0.03$ & 0.01 \\
\hline HEBR-08-01 & 0.96 & 0.36 & $<0.01$ & $<1.4$ & $<0.03$ & 4.1 & $<0.03$ & 0.01 \\
\hline 3-HEB-I & 0.6 & 0.24 & $<0.01$ & $<1.4$ & $<0.03$ & 17.3 & $<0.03$ & 0.05 \\
\hline 3-HEB-D & 0.36 & 0.21 & $<0.01$ & $<1.4$ & $<0.03$ & 14.2 & $<0.03$ & 0.04 \\
\hline
\end{tabular}

${ }^{1}$ USGS National Water-Quality Assessment program monitoring wells were included in 2010 sampling period, but were not equipped with real-time instrumentation. 


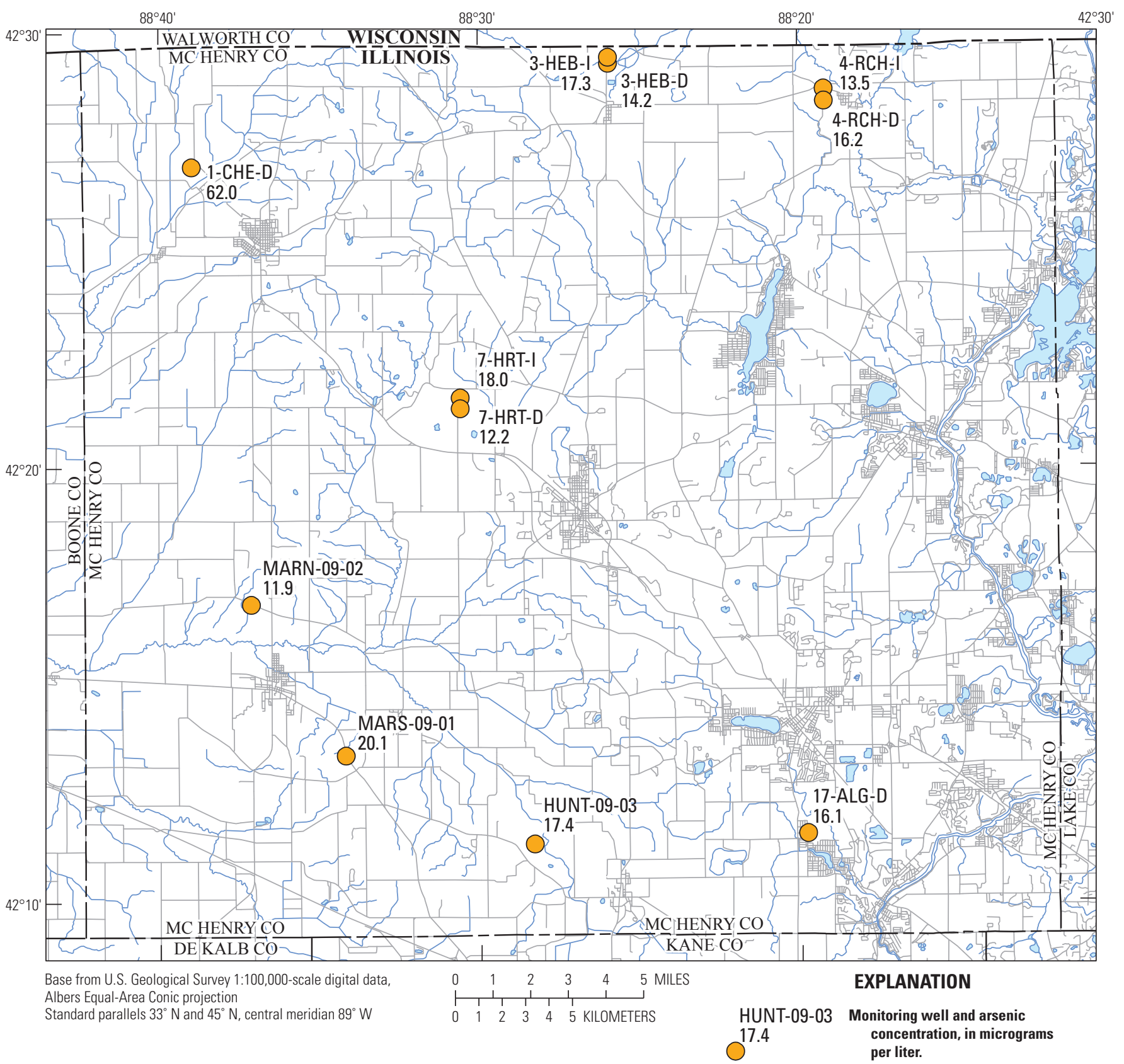

Figure 27. Arsenic concentrations greater than the U.S. Environmental Protection Agency Maximum Contaminant Level of 10 micrograms per liter from selected wells in the McHenry County groundwater monitoring network, Illinois, 2010. 
Molybdenum concentrations ranged from 0.36 to $33.8 \mu \mathrm{g} / \mathrm{L}$; the DWEL is $200 \mu \mathrm{g} / \mathrm{L}$ (U.S. Environmental Protection Agency, 2012). The highest concentration was detected at well MARS-09-01; the median concentration of all water-quality samples was only $1.97 \mu \mathrm{g} / \mathrm{L}$ (table 19). Uranium was detected in water-quality samples from every well in the study area, with concentrations ranging from 0.01 to $8.04 \mu \mathrm{g} / \mathrm{L}$ (table 19). The highest concentration was detected at well 10-MAR-S. The MCL for uranium is $30 \mu \mathrm{g} / \mathrm{L}$ and the DWEL is $20 \mu \mathrm{g} / \mathrm{L}$ (U.S. Environmental Protection Agency, 2012).

Iron (II) was measured in the field, and dissolved total iron was measured in the laboratory for water-quality samples from all 46 wells (table 19). Iron (II) was measured in the field to obtain concentration data for the determination of redox conditions using the Redox Assignment Model (Jurgens and others, 2009, as discussed in section, "Methods"). Iron is sensitive to redox conditions. High iron content is a common occurrence in the northern glacial aquifer system (Groschen and others, 2009). Concentrations of field measurements ranged from about 0 to $3.09 \mathrm{mg} / \mathrm{L}$, with a median concentration of $1.26 \mathrm{mg} / \mathrm{L}$. Concentrations of laboratory measurements were similar but slightly higher (less than 6 to $3,450 \mu \mathrm{g} / \mathrm{L}$ ). The SCML of $300 \mu \mathrm{g} / \mathrm{L}$ for iron was exceeded in 85 percent of the laboratory water-quality samples. The wells with the lowest iron concentrations primarily were shallow (less than $25 \mathrm{ft}$ below land surface), which likely is related to the relatively higher DO concentrations (about $1.30-4.00 \mathrm{mg} / \mathrm{L}$ ) recorded at these wells (fig. 28). At these DO concentrations, iron (II) is oxidized to iron (III) oxide, which renders it immobile. In deep wells where reducing conditions are present (DO concentrations of less than $1.0 \mathrm{mg} / \mathrm{L}$ ), iron oxides tend to dissolve and their concentrations increase in the groundwater (National Ground Water Association, 2010). Iron concentrations in excess of $300 \mu \mathrm{g} / \mathrm{L}$ can affect taste and cause staining of fabrics and household fixtures such as plumbing (National Ground Water Association, 2010). Like arsenic

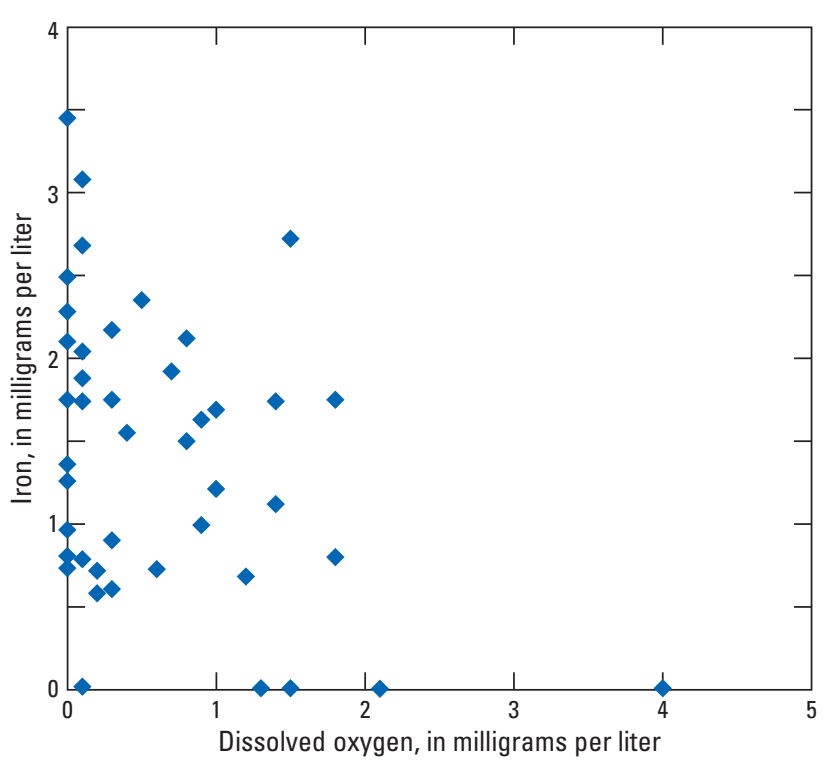

Figure 28. Total iron and dissolved-oxygen concentrations in McHenry County groundwater monitoring network, Illinois, 2010.

concentrations, iron concentrations also can be substantially reduced in drinking water through various water treatment methods (Thomas and Eckberg, 2015).

Trace elements occur in small amounts in nature (Ayotte and others, 2011). Most trace elements occur naturally in aquifer sediments, but anthropogenic inputs from sewage, storm-water drainage systems, irrigation, fertilizers, and combustion of fossil fuels may potentially increase the concentration of some trace elements in groundwater (Mahler and others, 2006). Eight wells were sampled for the trace elements lithium, strontium, thallium, vanadium, and boron (table 20). Selection of wells was based on well depth and

Table 20. Trace elements at selected monitoring wells in McHenry County, Illinois.

[Locations of monitoring wells are shown in figure 1. All values are in micrograms per liter. Abbreviations: E, estimated; $\mu \mathrm{gL}$, microgram per liter; USGS, U.S. Geological Survey; $<$, less than]

\begin{tabular}{lccccr}
\hline $\begin{array}{c}\text { Monitoring } \\
\text { well }\end{array}$ & Lithium & Strontium & Thallium & Vandium & Boron \\
\hline 17-ALG-S & 7 & 691 & $<0.02$ & $<0.16$ & 53 \\
43N8E-8.2 $\mathrm{c}^{1}$ & 5.3 & 123 & $<0.02$ & 1.4 & 33 \\
43N8E-3.7d & 7.2 & 108 & $<0.02$ & 1.0 & 151 \\
44N9E-20.7c & 9.3 & 176 & $\mathrm{E} 0.01$ & 3.3 & 25 \\
45N7E-32.4d & 11 & 111 & 0.09 & $\mathrm{E} 0.10$ & 19 \\
9-MCH-S & 3.9 & 180 & $<0.02$ & 0.36 & 91 \\
45N9E-7.6a & 7.1 & 130 & E0.01 & 1.8 & 111 \\
4-RCH-S & 10.2 & 342 & $<0.02$ & 0.17 & 24 \\
\hline
\end{tabular}

${ }^{1}$ USGS National Water-Quality Assessment Program monitoring wells were included in 2010 sampling period, but were not equipped with real-time instrumentation. 
proximity to urban areas. Lithium and vanadium do not have MCL or health advisory standards. Lithium concentrations ranged from 3.9 to $11 \mu \mathrm{g} / \mathrm{L}$, with a median concentration of $7.15 \mu \mathrm{g} / \mathrm{L}$ Strontium concentrations were below the EPA non-enforceable DWEL of $20 \mathrm{mg} / \mathrm{L}(20,000 \mu \mathrm{g} / \mathrm{L})$ and ranged from 108 to $691 \mu \mathrm{g} / \mathrm{L}$, with a median of $153 \mu \mathrm{g} / \mathrm{L}$. Vanadium concentrations ranged from less than 0.16 to $3.3 \mu \mathrm{g} / \mathrm{L}$, with a median concentration of $1.2 \mu \mathrm{g} / \mathrm{L}$. Thallium had only one confirmed detection at $0.09 \mu \mathrm{g} / \mathrm{L}$ (well 45N7E-32.4d). The MCL for thallium is $2 \mu \mathrm{g} / \mathrm{L}$. Boron is a naturally occurring element in nature and is an essential nutrient for plants that is found in sedimentary rocks and in soils formed from coal, shale, and minerals (U.S. Environmental Protection Agency, 2008). Anthropogenic inputs of boron are from fertilizers, herbicides, industrial waste, municipal sewage, detergents, and soaps (Lyday, 2003). Boron concentrations were below the EPA recommended, non-enforceable DWEL of $7 \mathrm{mg} / \mathrm{L}(7,000 \mu \mathrm{g} / \mathrm{L})$, with concentrations ranging from 19 to $151 \mu \mathrm{g} / \mathrm{L}$, with a median concentration of $43 \mu \mathrm{g} / \mathrm{L}$. The highest concentrations generally were detected in water-quality samples collected from wells near urban land use (9-MCH-S, 17-ALG-S, 45N9E-7.6a, and 43N8E-3.7d) (fig. 1). The highest boron concentration was detected at well 43N8E-3.7d.

\section{Pesticides and Volatile Organic Compounds}

Pesticides and herbicides have been used to control weeds, insects, and other pests to increase crop yields for decades (Gilliom and others, 2006). Water-quality samples for pesticide and herbicide concentrations were collected in eight shallow wells (less than $60 \mathrm{ft}$ below land surface) open to unconfined aquifer units. Of the 86 pesticides screened, only three were detected (table 21). Atrazine was detected at two of eight wells sampled (44N9E-20.7c and 9-MCH-S), with concentrations of 0.009 and $0.018 \mu \mathrm{g} / \mathrm{L}$. A degradation product of atrazine, CIAT (2-Chloro-4-isopropylamino-6amino-s-triazine) (also known as deethyl atrazine) (Loper and others, 2009) was detected in the sample from well 9-MCH-S at an estimated concentration of $0.023 \mu \mathrm{g} / \mathrm{L}$ and in three other wells at lower estimated concentrations below the method reporting limit. Atrazine is an extensively used herbicide for control of broadleaf weeds in crops and turf. Atrazine has a MCL of $0.003 \mathrm{mg} / \mathrm{L}(3 \mu \mathrm{g} / \mathrm{L})$ and a DWEL of $0.7 \mathrm{mg} / \mathrm{L}(7,000 \mu \mathrm{g} / \mathrm{L})$, and studies have shown atrazine to be linked with birth defects and feminization of a select number of amphibians (Goodman and others, 2014; Hayes and others, 2010). Prometon was detected at three of eight wells (43N8E-8.2c, 9-MCH-S, and 45N9E-7.6a) at concentrations of 0.016-0.006 $\mu \mathrm{g} / \mathrm{L}$. One well, 45N7E-32.4d, had an estimated $(\mathrm{E} 0.006 \mu \mathrm{g} / \mathrm{L})$ detection below the MRL. Prometon is a noncrop herbicide commonly used by industries and under and around asphalt as a total control for unwanted vegetation. Biodegradation is one of the only mechanisms to degrade prometon, but the process is slow (Capel and others, 1999). Pesticides also were detected above laboratory reporting limits in two NAWQA wells located in McHenry County (Morrow, 2002).

Volatile organic compounds (VOCs) are manmade organic compounds that are toxic to humans. VOCs are used by industrial, commercial, household, and military sources, and often are observed to transport and persist in groundwater (Zogorski and others, 2006). Sixteen wells open to unconfined, semi-confined, and confined aquifer units (maximum depth of $180 \mathrm{ft}$ below land surface) were sampled for VOCs. Of the 76 VOCs screened (table 22), only 3 were detected above the MRL. Trichloroethene (TCE) was detected in the sample collected in 1 of the 16 wells (44N9E-20.7c) at a concentration of $0.13 \mu \mathrm{g} / \mathrm{L}$; the MCL for TCE is $5 \mu \mathrm{g} / \mathrm{L}$. TCE is a common cleaning solvent used by dry cleaners and by industries as a degreaser for metal parts. Exposure to this organic compound can affect cardiovascular, immune, renal, and hepatic systems, and fetal development (U.S. Environmental Protection Agency, 2011). Trichloromethane (or chloroform) was detected in water-quality samples from 5 of 16 wells (43N8E-8.2c, 15-COR-S, 44N9E-20.7c, 9-MCH-S, and 45N9E-7.6a), with a maximum concentration of $0.5 \mu \mathrm{g} / \mathrm{L}$ at $15-\mathrm{COR}-\mathrm{S}$. An estimated concentration, below the MRL, of trichloromethane $(\mathrm{E} 0.01 \mu \mathrm{g} / \mathrm{L})$ was detected in 17-ALG-S. The detected concentrations are much less than the MCL of $100 \mu \mathrm{g} / \mathrm{L}$ for total trihalomethanes (includes trichloromethane). Trichloromethane, a byproduct of chlorination of public-water supplies, indicates water is entering groundwater in the county from either lawn irrigation or leaking pipes (water or sewer lines) (Ivahnenko and Zogorski, 2006). Tetrachloroethene was detected at an estimated, below the MRL $(0.026 \mu \mathrm{g} / \mathrm{L})$, concentration of $0.02 \mu \mathrm{g} / \mathrm{L}$ at $9-\mathrm{MCH}-\mathrm{S}$. Similar concentrations of VOCs were detected in three monitoring wells and three domestic wells in McHenry County from a previous study (Morrow, 2002). Both VOCs and pesticides were detected at three monitoring wells, 9-MCH-S, 44N9E-20.7c, 45N9E-7.6a. These wells are located in urban areas. 
Table 21. Pesticide and herbicide results from water-quality samples collected from selected monitoring wells in the McHenry County groundwater monitoring network, Illinois.

[Locations of monitoring wells are shown in figure 1. All values are in micrograms per liter. Monitoring well: Wells 43N8E-82.c, 43N8E-3.7d, 45N7E-32.4d, and 45N93E-7.6a are USGS National Water-Quality Assessment program monitoring wells included in 2010 sampling period, but not equipped with real-time instrumentation. Detections are in bold, estimated (E) are in bold only if equal to or greater than the method reporting limit. The less than values $(<)$ are considered nondetects less than the detection limit]

\begin{tabular}{|c|c|c|c|c|c|c|c|c|}
\hline \multirow{2}{*}{ Pesticide or herbicide } & \multicolumn{8}{|c|}{ Monitoring well } \\
\hline & 17-ALG-S & 43N8E-8.2c & 43N8E-3.7d & 44N9E-20.7c & 45N7E-32.4d & 9-MCH-S & 45N9E-7.6a & 4-RCH-S \\
\hline 1-Naphthol & $<0.036$ & $<0.036$ & $<0.036$ & $<0.036$ & $<0.036$ & $<0.036$ & $<0.036$ & $<0.036$ \\
\hline 2,6-Diethylaniline & $<0.006$ & $<0.006$ & $<0.006$ & $<0.006$ & $<0.006$ & $<0.006$ & $<0.006$ & $<0.006$ \\
\hline Alachlor 2nd amide & $<0.010$ & $<0.010$ & $<0.010$ & $<0.010$ & $<0.010$ & $<0.010$ & $<0.010$ & $<0.010$ \\
\hline $\begin{array}{l}\text { 2-Chloro-4-isopropylamino-6- } \\
\text { amino-s-triazine (CIAT) }\end{array}$ & $<0.014$ & E0.004 & $<0.014$ & E0.010 & $<0.014$ & E0.023 & E0.007 & $<0.014$ \\
\hline 2-Ethyl-6-methylaniline & $<0.010$ & $<0.010$ & $<0.010$ & $<0.010$ & $<0.010$ & $<0.010$ & $<0.010$ & $<0.010$ \\
\hline 3,4-Dichloroaniline & $<0.004$ & $<0.004$ & $<0.004$ & $<0.004$ & $<0.004$ & $<0.004$ & $<0.004$ & $<0.004$ \\
\hline 3,5-Dichloroaniline & $<0.003$ & $<0.003$ & $<0.003$ & $<0.003$ & $<0.003$ & $<0.003$ & $<0.003$ & $<0.003$ \\
\hline 3-Chloropropene & $<0.08$ & $<0.08$ & $<0.08$ & $<0.08$ & $<0.08$ & $<0.08$ & $<0.08$ & $<0.08$ \\
\hline 4-Chloro-2-methylphenol & $<0.003$ & $<0.003$ & $<0.003$ & $<0.003$ & $<0.003$ & $<0.003$ & $<0.003$ & $<0.003$ \\
\hline Acetochlor & $<0.010$ & $<0.010$ & $<0.010$ & $<0.010$ & $<0.010$ & $<0.010$ & $<0.010$ & $<0.010$ \\
\hline Acrylonitrile & $<0.8$ & $<0.8$ & $<0.8$ & $<0.8$ & $<0.8$ & $<0.8$ & $<0.8$ & $<0.8$ \\
\hline Alachlor & $<0.008$ & $<0.008$ & $<0.008$ & $<0.008$ & $<0.008$ & $<0.008$ & $<0.008$ & $<0.009$ \\
\hline alpha-Endosulfan & $<0.006$ & $<0.006$ & $<0.006$ & $<0.006$ & $<0.006$ & $<0.006$ & $<0.006$ & $<0.006$ \\
\hline Atrazine & $<0.007$ & $<0.007$ & $<0.007$ & 0.009 & $<0.007$ & 0.018 & $<0.007$ & $<0.007$ \\
\hline Azinphos-methyl oxon & $<0.04$ & $<0.04$ & $<0.04$ & $<0.04$ & $<0.04$ & $<0.04$ & $<0.04$ & $<0.04$ \\
\hline Azinphos-methyl & $<0.120$ & $<0.120$ & $<0.120$ & $<0.120$ & $<0.120$ & $<0.120$ & $<0.04$ & $<0.04$ \\
\hline Benfluralin & $<0.014$ & $<0.014$ & $<0.014$ & $<0.014$ & $<0.014$ & $<0.014$ & $<0.014$ & $<0.014$ \\
\hline Carbaryl & $<0.060$ & $<0.060$ & $<0.060$ & $<0.060$ & $<0.060$ & $<0.060$ & $<0.060$ & $<0.060$ \\
\hline Carbofuran & $<0.060$ & $<0.060$ & $<0.060$ & $<0.060$ & $<0.060$ & $<0.060$ & $<0.060$ & $<0.060$ \\
\hline Carbon disulfide & $<0.04$ & $<0.04$ & $<0.04$ & $<0.04$ & $<0.04$ & $<0.04$ & $<0.04$ & $<0.04$ \\
\hline Chlorpyrifos oxon & $<0.05$ & $<0.05$ & $<0.05$ & $<0.05$ & $<0.05$ & $<0.05$ & $<0.05$ & $<0.05$ \\
\hline cis-1,3-Dichloropropene & $<0.10$ & $<0.10$ & $<0.10$ & $<0.10$ & $<0.10$ & $<0.10$ & $<0.010$ & $<0.010$ \\
\hline Chlorpyrifos & $<0.010$ & $<0.010$ & $<0.010$ & $<0.010$ & $<0.010$ & $<0.010$ & $<0.010$ & $<0.010$ \\
\hline cis-Permethrin & $<0.014$ & $<0.014$ & $<0.014$ & $<0.014$ & $<0.014$ & $<0.014$ & $<0.014$ & $<0.014$ \\
\hline cis-Propiconazole & $<0.006$ & $<0.006$ & $<0.006$ & $<0.006$ & $<0.006$ & $<0.006$ & $<0.006$ & $<0.006$ \\
\hline Cyanazine & $<0.022$ & $<0.022$ & $<0.022$ & $<0.022$ & $<0.022$ & $<0.022$ & $<0.022$ & $<0.022$ \\
\hline Cyfluthrin & $<0.016$ & $<0.016$ & $<0.016$ & $<0.016$ & $<0.016$ & $<0.016$ & $<0.016$ & $<0.016$ \\
\hline Cypermethrin & $<0.020$ & $<0.020$ & $<0.020$ & $<0.020$ & $<0.020$ & $<0.020$ & $<0.020$ & $<0.020$ \\
\hline $\begin{array}{l}\text { Dimethyl tetrachloroterephthalate } \\
\text { (DCPA) }\end{array}$ & $<0.008$ & $<0.008$ & $<0.008$ & $<0.008$ & $<0.008$ & $<0.008$ & $<0.008$ & $<0.008$ \\
\hline Desulfinylfipronil amide & $<0.029$ & $<0.029$ & $<0.029$ & $<0.029$ & $<0.029$ & $<0.029$ & $<0.029$ & $<0.029$ \\
\hline Desulfinylfipronil & $<0.012$ & $<0.012$ & $<0.012$ & $<0.012$ & $<0.012$ & $<0.012$ & $<0.012$ & $<0.012$ \\
\hline Diazinon & $<0.005$ & $<0.005$ & $<0.005$ & $<0.005$ & $<0.005$ & $<0.005$ & $<0.005$ & $<0.005$ \\
\hline Dichlorvos & $<0.02$ & $<0.02$ & $<0.02$ & $<0.02$ & $<0.02$ & $<0.02$ & $<0.02$ & $<0.02$ \\
\hline Dicrotophos & $<0.08$ & $<0.08$ & $<0.08$ & $<0.08$ & $<0.08$ & $<0.08$ & $<0.08$ & $<0.08$ \\
\hline Dieldrin & $<0.009$ & $<0.009$ & $<0.009$ & $<0.009$ & $<0.009$ & $<0.009$ & $<0.009$ & $<0.009$ \\
\hline Dimethoate & $<0.006$ & $<0.006$ & $<0.006$ & $<0.006$ & $<0.006$ & $<0.006$ & $<0.006$ & $<0.006$ \\
\hline Disulfoton sulfone & $<0.01$ & $<0.01$ & $<0.01$ & $<0.01$ & $<0.01$ & $<0.01$ & $<0.01$ & $<0.01$ \\
\hline Disulfoton & $<0.04$ & $<0.04$ & $<0.04$ & $<0.04$ & $<0.04$ & $<0.04$ & $<0.04$ & $<0.04$ \\
\hline Endosulfan sulfate & $<0.014$ & $<0.014$ & $<0.014$ & $<0.014$ & $<0.014$ & $<0.014$ & $<0.014$ & $<0.014$ \\
\hline s-ethyl dipropylthiocarbamate & $<0.002$ & $<0.002$ & $<0.002$ & $<0.002$ & $<0.002$ & $<0.002$ & $<0.002$ & $<0.002$ \\
\hline
\end{tabular}

(EPTC) 
Table 21. Pesticide and herbicide results from water-quality samples collected from selected monitoring wells in the McHenry County groundwater monitoring network, Illinois._- Continued

\begin{tabular}{|c|c|c|c|c|c|c|c|c|}
\hline \multirow{2}{*}{ Pesticide or herbicide } & \multicolumn{8}{|c|}{ Monitoring well } \\
\hline & 17-ALG-S & 43N8E-8.2c & 43N8E-3.7d & 44N9E-20.7c & 45N7E-32.4d & 9-MCH-S & 45N9E-7.6a & 4-RCH-S \\
\hline Ethion monoxon & $<0.02$ & $<0.02$ & $<0.02$ & $<0.02$ & $<0.02$ & $<0.02$ & $<0.02$ & $<0.02$ \\
\hline Ethion & $<0.008$ & $<0.008$ & $<0.008$ & $<0.008$ & $<0.008$ & $<0.008$ & $<0.008$ & $<0.008$ \\
\hline Ethoprop & $<0.016$ & $<0.016$ & $<0.016$ & $<0.016$ & $<0.016$ & $<0.016$ & $<0.016$ & $<0.016$ \\
\hline Fenamiphos sulfone & $<0.053$ & $<0.053$ & $<0.053$ & $<0.053$ & $<0.053$ & $<0.053$ & $<0.053$ & $<0.053$ \\
\hline Fenamiphos sulfoxide & $<0.08$ & $<0.08$ & $<0.08$ & $<0.08$ & $<0.08$ & $<0.08$ & $<0.08$ & $<0.08$ \\
\hline Fenamiphos & $<0.03$ & $<0.03$ & $<0.03$ & $<0.03$ & $<0.03$ & $<0.03$ & $<0.03$ & $<0.03$ \\
\hline Fipronil sulfide & $<0.013$ & $<0.013$ & $<0.013$ & $<0.013$ & $<0.013$ & $<0.013$ & $<0.013$ & $<0.013$ \\
\hline Fipronil sulfone & $<0.024$ & $<0.024$ & $<0.024$ & $<0.024$ & $<0.024$ & $<0.024$ & $<0.024$ & $<0.024$ \\
\hline Fipronil & $<0.018$ & $<0.018$ & $<0.018$ & $<0.018$ & $<0.018$ & $<0.018$ & $<0.018$ & $<0.018$ \\
\hline Fonofos & $<0.004$ & $<0.004$ & $<0.004$ & $<0.004$ & $<0.004$ & $<0.004$ & $<0.004$ & $<0.004$ \\
\hline Hexazinone & $<0.008$ & $<0.008$ & $<0.008$ & $<0.008$ & $<0.008$ & $<0.008$ & $<0.008$ & $<0.008$ \\
\hline Iodomethane & $<0.26$ & $<0.26$ & $<0.26$ & $<0.26$ & $<0.26$ & $<0.26$ & $<0.26$ & $<0.26$ \\
\hline Iprodione & $<0.014$ & $<0.014$ & $<0.014$ & $<0.014$ & $<0.014$ & $<0.014$ & $<0.014$ & $<0.014$ \\
\hline Isofenphos & $<0.006$ & $<0.006$ & $<0.006$ & $<0.006$ & $<0.006$ & $<0.006$ & $<0.006$ & $<0.006$ \\
\hline lambda-Cyhalothrin & $<0.010$ & $<0.010$ & $<0.010$ & $<0.010$ & $<0.010$ & $<0.010$ & $<0.010$ & $<0.010$ \\
\hline Malaoxon & $<0.080$ & $<0.080$ & $<0.080$ & $<0.080$ & $<0.080$ & $<0.080$ & $<0.080$ & $<0.080$ \\
\hline Malathion & $<0.016$ & $<0.016$ & $<0.016$ & $<0.016$ & $<0.016$ & $<0.016$ & $<0.016$ & $<0.016$ \\
\hline Metalaxyl & $<0.007$ & $<0.007$ & $<0.007$ & $<0.007$ & $<0.007$ & $<0.007$ & $<0.007$ & $<0.007$ \\
\hline Methidathion & $<0.006$ & $<0.006$ & $<0.006$ & $<0.006$ & $<0.006$ & $<0.006$ & $<0.006$ & $<0.006$ \\
\hline Methyl paraoxon & $<0.01$ & $<0.01$ & $<0.01$ & $<0.01$ & $<0.01$ & $<0.01$ & $<0.01$ & $<0.01$ \\
\hline Methyl parathion & $<0.008$ & $<0.008$ & $<0.008$ & $<0.008$ & $<0.008$ & $<0.008$ & $<0.008$ & $<0.008$ \\
\hline Metolachlor & $<0.014$ & $<0.014$ & $<0.014$ & $<0.014$ & $<0.014$ & $<0.014$ & $<0.014$ & $<0.014$ \\
\hline Metribuzin & $<0.012$ & $<0.012$ & $<0.012$ & $<0.012$ & $<0.012$ & $<0.012$ & $<0.012$ & $<0.012$ \\
\hline Molinate & $<0.003$ & $<0.004$ & $<0.003$ & $<0.003$ & $<0.003$ & $<0.003$ & $<0.003$ & $<0.003$ \\
\hline Myclobutanil & $<0.010$ & $<0.010$ & $<0.010$ & $<0.010$ & $<0.010$ & $<0.010$ & $<0.010$ & $<0.010$ \\
\hline Oxyfluorfen & $<0.010$ & $<0.010$ & $<0.010$ & $<0.010$ & $<0.010$ & $<0.010$ & $<0.010$ & $<0.010$ \\
\hline Pendimethalin & $<0.012$ & $<0.012$ & $<0.012$ & $<0.012$ & $<0.012$ & $<0.012$ & $<0.012$ & $<0.012$ \\
\hline Phorate oxon & $<0.03$ & $<0.03$ & $<0.03$ & $<0.03$ & $<0.03$ & $<0.03$ & $<0.03$ & $<0.03$ \\
\hline Phorate & $<0.020$ & $<0.020$ & $<0.020$ & $<0.020$ & $<0.020$ & $<0.020$ & $<0.020$ & $<0.020$ \\
\hline Phosmet oxon & $<0.05$ & $<0.05$ & $<0.05$ & $<0.05$ & $<0.05$ & $<0.05$ & $<0.05$ & $<0.05$ \\
\hline Phosmet & $<0.034$ & $<0.034$ & $<0.034$ & $<0.034$ & $<0.034$ & $<0.034$ & $<0.034$ & $<0.034$ \\
\hline Prometon & $<0.012$ & 0.016 & $<0.012$ & $<0.012$ & E0.006 & 0.06 & 0.02 & $<0.012$ \\
\hline Prometryn & $<0.006$ & $<0.006$ & $<0.006$ & $<0.006$ & $<0.006$ & $<0.006$ & $<0.006$ & $<0.006$ \\
\hline Propanil & $<0.010$ & $<0.010$ & $<0.010$ & $<0.010$ & $<0.010$ & $<0.010$ & $<0.010$ & $<0.010$ \\
\hline Propargite & $<0.02$ & $<0.02$ & $<0.02$ & $<0.02$ & $<0.02$ & $<0.02$ & $<0.02$ & $<0.02$ \\
\hline Propyzamide & $<0.004$ & $<0.004$ & $<0.004$ & $<0.004$ & $<0.004$ & $<0.004$ & $<0.004$ & $<0.004$ \\
\hline Simazine & $<0.006$ & $<0.006$ & $<0.006$ & $<0.006$ & $<0.006$ & $<0.006$ & $<0.006$ & $<0.006$ \\
\hline Tebuthiuron & $<0.03$ & $<0.03$ & $<0.03$ & $<0.03$ & $<0.03$ & $<0.03$ & $<0.03$ & $<0.03$ \\
\hline Tefluthrin & $<0.010$ & $<0.010$ & $<0.010$ & $<0.010$ & $<0.010$ & $<0.010$ & $<0.010$ & $<0.010$ \\
\hline Terbufos oxon sulfone & $<0.04$ & $<0.04$ & $<0.04$ & $<0.04$ & $<0.04$ & $<0.04$ & $<0.04$ & $<0.04$ \\
\hline Terbufos & $<0.02$ & $<0.02$ & $<0.02$ & $<0.02$ & $<0.02$ & $<0.02$ & $<0.02$ & $<0.02$ \\
\hline Terbuthylazine & $<0.01$ & $<0.01$ & $<0.01$ & $<0.01$ & $<0.01$ & $<0.01$ & $<0.01$ & $<0.01$ \\
\hline Thiobencarb & $<0.016$ & $<0.016$ & $<0.016$ & $<0.016$ & $<0.016$ & $<0.016$ & $<0.016$ & $<0.016$ \\
\hline trans-Propiconazole & $<0.02$ & $<0.02$ & $<0.02$ & $<0.02$ & $<0.02$ & $<0.02$ & $<0.02$ & $<0.02$ \\
\hline Tribuphos & $<0.018$ & $<0.018$ & $<0.018$ & $<0.018$ & $<0.018$ & $<0.018$ & $<0.018$ & $<0.018$ \\
\hline Trifluralin & $<0.018$ & $<0.018$ & $<0.018$ & $<0.018$ & $<0.018$ & $<0.018$ & $<0.018$ & $<0.018$ \\
\hline
\end{tabular}


Table 22. Volatile organic compound water-quality samples collected from selected wells in the McHenry County groundwater monitoring network, Illinois, 2010.

[Locations of monitoring wells are shown in figure 1. All concentrations are in micrograms per liter, unless otherwise noted. Bold values indicate detections. Abbreviations: E, estimated value; estimated values (E) are in bold only if equal to or greater than the method reporting limit; $\mathrm{mg} / \mathrm{L}, \mathrm{milligram} \mathrm{per} \mathrm{liter;} \mathrm{U,}$ nondetect; $<$, less than the reporting limit; - , not analyzed]

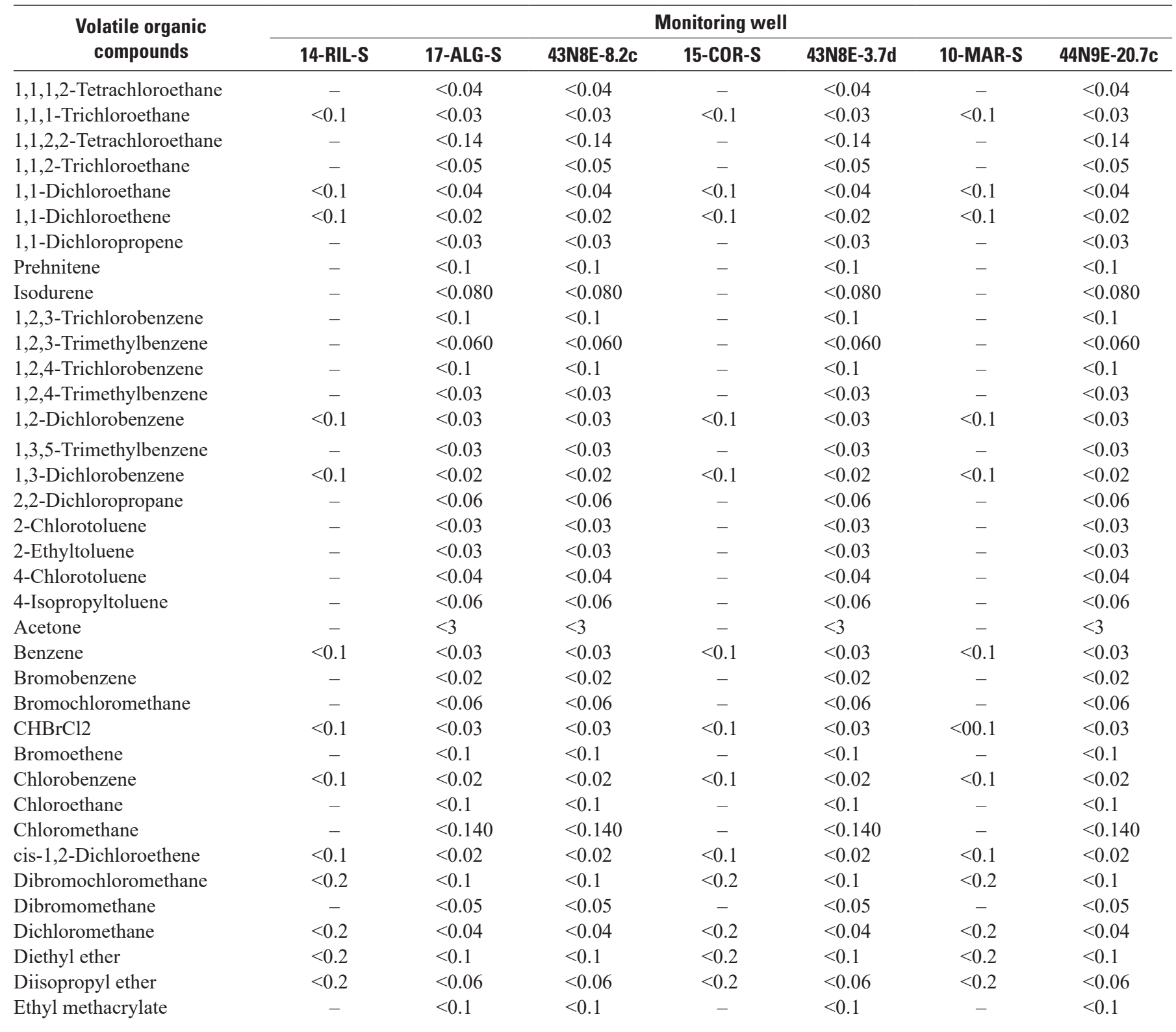


Table 22. Volatile organic compound water-quality samples collected from selected wells in the McHenry County groundwater monitoring network, Illinois, 2010.-Continued

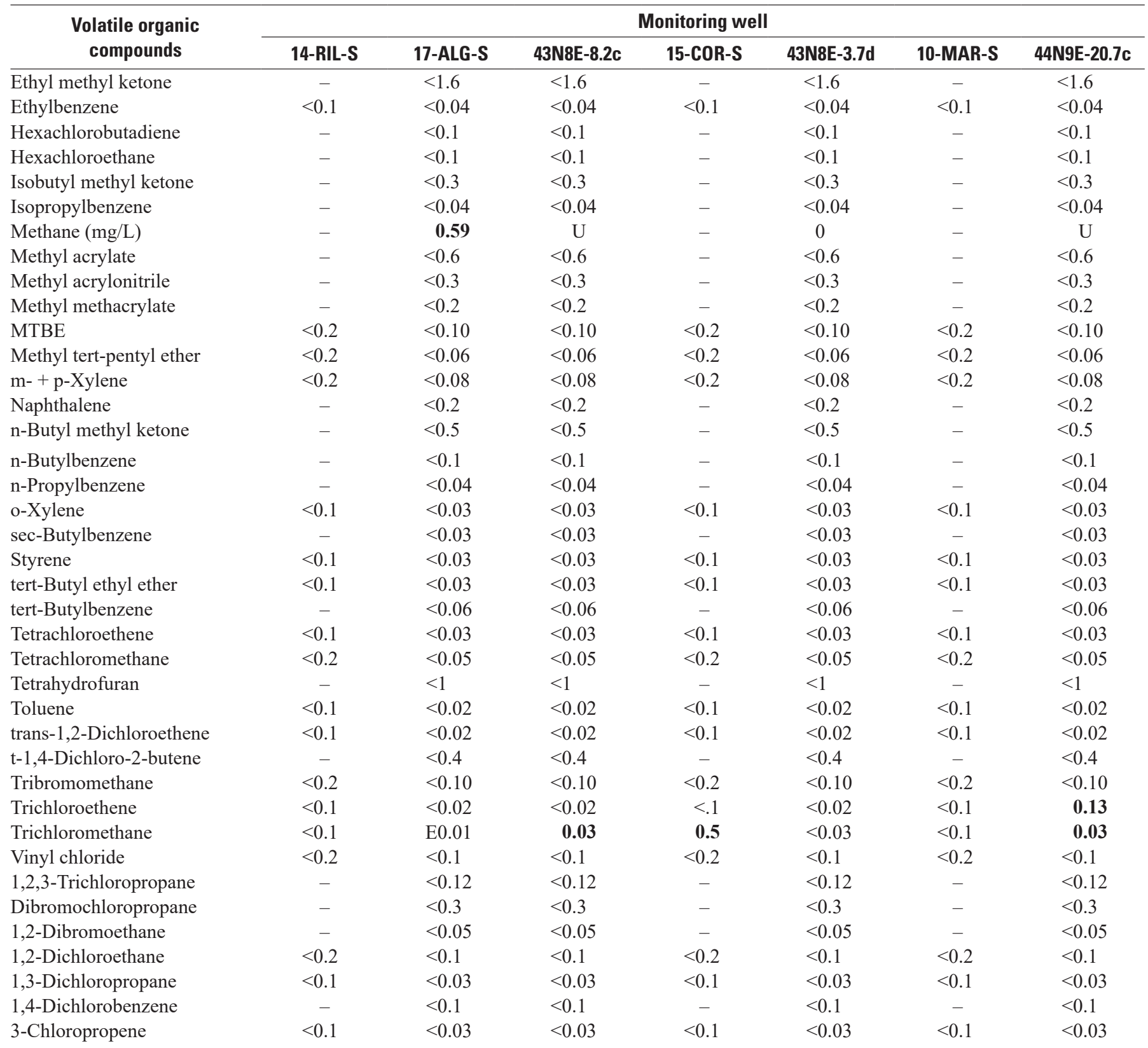


Table 22. Volatile organic compound water-quality samples collected from selected wells in the McHenry County groundwater monitoring network, Illinois, 2010.-Continued

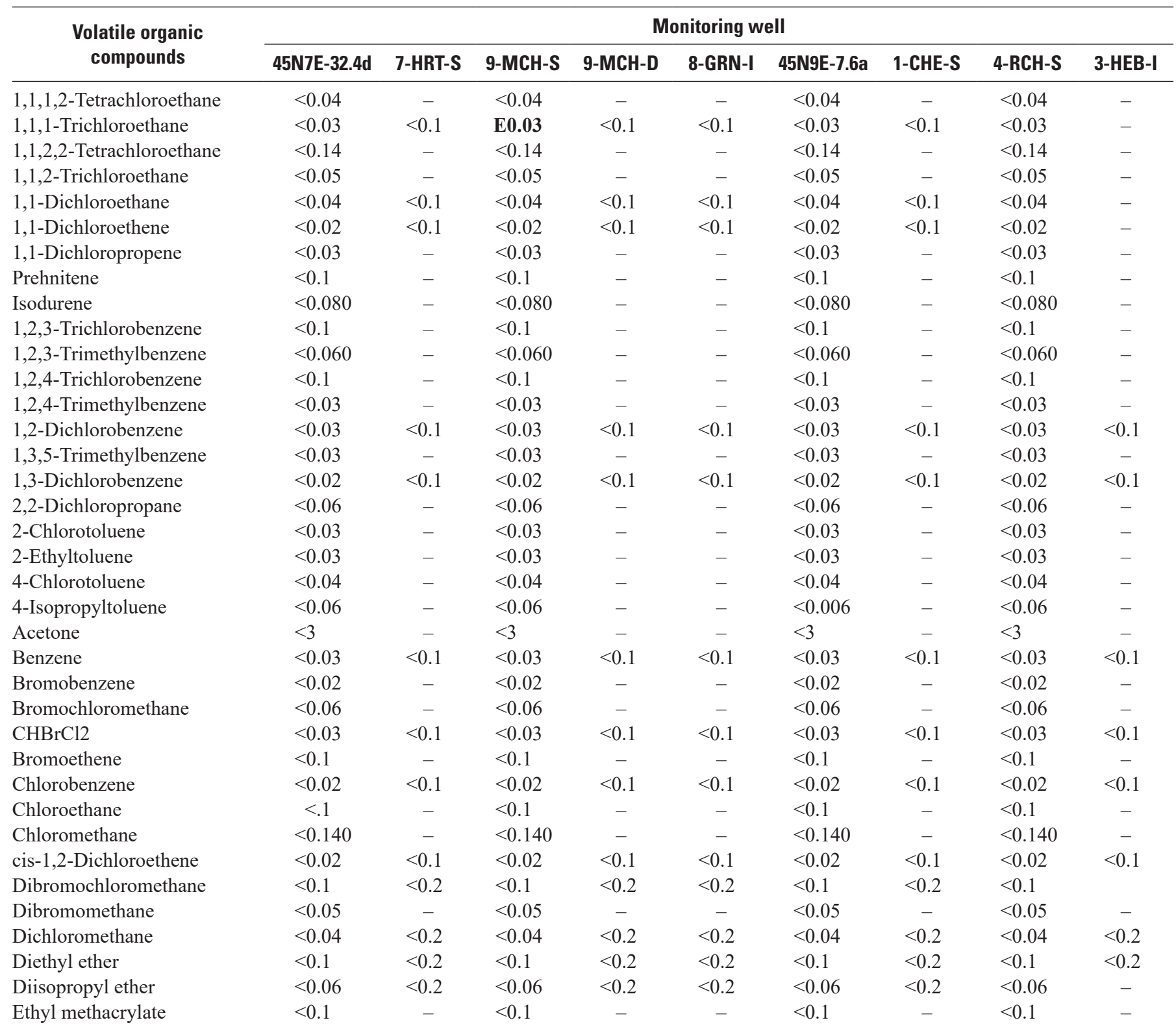


Table 22. Volatile organic compound water-quality samples collected from selected wells in the McHenry County groundwater monitoring network, Illinois, 2010.-Continued

\begin{tabular}{|c|c|c|c|c|c|c|c|c|c|}
\hline \multirow{2}{*}{$\begin{array}{l}\text { Volatile organic } \\
\text { compounds }\end{array}$} & \multicolumn{9}{|c|}{ Monitoring well } \\
\hline & 45N7E-32.4d & 7-HRT-S & 9-MCH-S & 9-MCH-D & 8-GRN-I & 45N9E-7.6a & 1-CHE-S & 4-RCH-S & 3-HEB-I \\
\hline Ethyl methyl ketone & $<1.6$ & - & $<1.6$ & - & - & $<1.6$ & - & $<1.6$ & - \\
\hline Hexachlorobutadiene & $<0.1$ & - & $<0.1$ & - & - & $<0.1$ & - & $<0.1$ & - \\
\hline Hexachloroethane & $<0.1$ & - & $<0.1$ & - & - & $<0.1$ & - & $<0.1$ & - \\
\hline Isobutyl methyl ketone & $<0.3$ & - & $<0.3$ & - & - & $<0.3$ & - & $<0.3$ & - \\
\hline Methyl acrylate & $<0.6$ & - & $<0.6$ & - & - & $<0.6$ & - & $<0.6$ & - \\
\hline Methyl acrylonitrile & $<0.3$ & - & $<0.3$ & - & - & $<0.3$ & - & $<0.3$ & - \\
\hline Methyl methacrylate & $<0.2$ & - & $<0.2$ & - & - & $<0.2$ & - & $<0.2$ & - \\
\hline MTBE & $<0.10$ & $<0.2$ & $<0.10$ & $<0.2$ & $<0.2$ & $<0.10$ & $<0.2$ & $<0.10$ & $<0.2$ \\
\hline Methyl tert-pentyl ether & $<0.06$ & $<0.2$ & $<0.06$ & $<0.2$ & $<0.2$ & $<0.06$ & $<0.2$ & $<0.06$ & $<0.2$ \\
\hline n-Propylbenzene & $<0.04$ & - & $<0.04$ & - & - & $<0.04$ & - & $<0.04$ & - \\
\hline o-Xylene & $<0.03$ & $<0.1$ & $<0.03$ & $<0.1$ & $<0.1$ & $<0.03$ & $<0.1$ & $<0.03$ & $<0.1$ \\
\hline sec-Butylbenzene & $<0.03$ & - & $<0.03$ & - & - & $<0.03$ & - & $<0.03$ & - \\
\hline Styrene & $<0.03$ & $<0.1$ & $<0.03$ & $<0.1$ & $<0.1$ & $<0.03$ & $<0.1$ & $<0.03$ & $<0.1$ \\
\hline tert-Butyl ethyl ether & $<0.03$ & $<0.1$ & $<0.03$ & $<0.1$ & $<0.1$ & $<0.03$ & $<0.1$ & $<0.03$ & $<0.1$ \\
\hline tert-Butylbenzene & $<0.06$ & - & $<0.06$ & - & - & $<0.06$ & - & $<0.06$ & - \\
\hline Tetrachloroethene & $<0.03$ & $<0.1$ & E0.02 & $<0.1$ & $<0.1$ & $<0.03$ & $<0.1$ & $<0.03$ & $<0.1$ \\
\hline Tetrachloromethane & $<0.05$ & $<0.2$ & $<0.05$ & $<0.2$ & $<0.2$ & $<0.05$ & $<0.2$ & $<0.05$ & $<0.1$ \\
\hline Tetrahydrofuran & $<1$ & - & $<1$ & - & - & $<1$ & - & $<1$ & - \\
\hline Toluene & $<0.02$ & $<0.1$ & $<0.02$ & $<0.1$ & $<0.1$ & $<0.02$ & $<0.1$ & $<0.02$ & $<0.1$ \\
\hline trans-1,2-Dichloroethene & $<0.02$ & $<0.1$ & $<0.02$ & $<0.1$ & $<0.1$ & $<0.02$ & $<0.1$ & $<0.02$ & $<0.1$ \\
\hline 1,2-Dibromoethane & $<0.05$ & - & $<0.05$ & - & - & $<0.05$ & - & $<0.05$ & - \\
\hline 1,2-Dichloroethane & $<0.1$ & $<0.2$ & $<0.1$ & $<0.2$ & $<0.2$ & $<0.1$ & $<0.2$ & $<0.1$ & - \\
\hline 1,3-Dichloropropane & $<0.03$ & $<0.1$ & $<0.03$ & $<0.1$ & $<0.1$ & $<0.03$ & $<0.1$ & $<0.03$ & - \\
\hline 1,4-Dichlorobenzene & $<0.1$ & - & $<0.1$ & - & - & $<0.1$ & - & $<0.1$ & - \\
\hline 3-Chloropropene & $<0.03$ & $<0.1$ & $<0.03$ & $<0.1$ & $<0.1$ & $<0.03$ & $<0.1$ & $<0.03$ & - \\
\hline
\end{tabular}




\section{Subsurface 0xidation-Reduction Processes}

Microbes in the subsurface use various constituents as an energy source by exploiting electron acceptors and donors. They have evolved to process this exploitation in the following order: oxygen to nitrates to manganese to iron (III) to sulfates and, lastly, to carbon dioxide (Fetter, 1998). Dissolved oxygen (DO) enters the groundwater through infiltrating precipitation and is consumed readily by microbes. As the DO is consumed, the water becomes more reducing as it moves downgradient.

Redox conditions control the concentration, transport, and fate of many constituents. Some constituents that are sensitive to redox conditions are DO, arsenic, iron, manganese, nitrate, pesticides and VOCs. The aesthetic quality of water is controlled by redox processes and influences the persistence of these constituents (Chapelle and others, 2003; McMahon and Chapelle, 2008). The water-quality concentrations for DO, nitrates, manganese, iron, sulfates, and sulfide were used to determine the dominant redox category (oxic, suboxic, anoxic, mixed) and redox process related to TEAP (table 23). Oxic and suboxic categories are considered oxidizing; anoxic is considered reducing. Suboxic conditions are indicated by low oxygen levels; however, additional data are needed to further define the redox process (Jurgens and others, 2009).

Of the aquifer units in the county represented at various well sites, 39 percent were categorized as anoxic, 35 percent as mixed, 15 percent as oxic, and 11 percent as suboxic (table 23). Oxic and suboxic conditions typically were identified at locations of shallow (less than $25 \mathrm{ft}$ below land surface) wells. However, oxic or suboxic conditions also were identified at locations of deep (as much as $344 \mathrm{ft}$ below land surface) wells, indicating that younger oxygenated waters reach these depths relatively quickly in areas of recharge. Three water-quality samples collected from wells 11-SEN-D, MARN-09-02, and 7-HRT-I were methanogenic, indicating the most strongly reducing conditions.

The complex hydrogeology of the glacial aquifers is evident in the redox delineations and concentrations of arsenic, manganese, and iron that were detected at concentrations greater than drinking water standards for health-based and aesthetically based standards. To help identify these differences, boxplots of redox results were divided into their respective categories of oxic, suboxic, mixed, and anoxic for the redox-sensitive constituents of arsenic, manganese, and iron (fig. 29). Arsenic, manganese, and iron exceeded health-based and (or) aesthetically based standards in anoxic and suboxic redox conditions, but exceedances also occurred in mixed and oxic conditions in a few instances.

Arsenic commonly is dissolved in the groundwater under strongly reducing conditions and flows along groundwater flow paths wherever the reducing conditions persist. Arsenic concentrations tended to have greater frequency of exceedances (greater than the MCL of $10 \mu \mathrm{g} / \mathrm{L}$ ) in anoxic and suboxic conditions, as expected; however, elevated concentrations also were present in all other conditions. The redox conditions at the well sites may control the transport, such that reducing conditions continue to dissolve arsenic and keep it in solution, and oxic zones remove arsenic from solution limiting the downgradient transport.

Manganese concentrations exceeded the SCML $(50 \mu \mathrm{g} / \mathrm{L})$ primarily at well sites under anoxic or mixed redox conditions, with the greatest range occurring under mixed redox conditions. Iron concentrations were high at all well sites except at a few sites that were determined to be oxic, where the evaluated wells also were shallow (less than $50 \mathrm{ft}$ below land surface). Iron concentrations exceeded its SMCL $(300 \mu \mathrm{g} / \mathrm{L})$ in all redox conditions; however, concentrations were highest in anoxic, suboxic, and mixed conditions. Nitrate concentrations commonly were detected in water-quality samples from wells with oxic and mixed conditions.

Pesticides and VOCs commonly were detected in water-quality samples that indicated mixed conditions, where the reducing redox processes were iron (III) to sulfate reducing. One well (9-MCH-S), where detections of pesticides (prometon and 2-Chloro-4-isopropylamino-6-amino-s-triazine [CIAT]) were detected (table 21), had oxic conditions, which can potentially inhibit the degradation of these organic compounds. Some VOCs break down readily in reducing environments (Lawrence, 2006), but the process may be inhibited because of the oscillating redox conditions (indicated by mixed).

The redox conditions determined for each well site are shown in figure 30. At most sites determined to be oxic, the wells are shallow (less than $25 \mathrm{ft}$ below land surface). This relation is expected, as these locations have been identified as readily receiving recharge from precipitation into the aquifer. Vertical gradient determinations somewhat agree with the determination of oxic or mixed areas and areas of recharge. Wells along the eastern one-half of the county are mixed, whereas some wells indicating downward vertical flow (recharge) are anoxic (11-SEN-I, 11-SEN-D; 7-HRT-S, 7-HRT-I, 7-HRT-D). Other factors (such as soil, minerals, and organic carbon content) may be contributing to the redox environment in these wells. The well nest, 4-RCH-S/I/D, represents oxic conditions throughout the entire column despite massive tills that separate the sand and gravel units represented in the well logs. The respective aquifer units tapped by wells 4-RCH-I and -D are considered semi-confined and interconnected. The oxic conditions throughout each of the units (Haeger-Beverly Unit, Upper Glasford Sand Unit, Shallow Bedrock and Lower Glasford Sand Units) monitored by the nested 4-RCH-S/I/D wells may indicate that the recharge area is nearby and receiving younger oxygenated waters from precipitation. This well nest also has a mixture of upward and downward vertical hydraulic gradients.

Additionally, redox conditions are sensitive to changes in the groundwater quantity and quality. Therefore, periodic or multiple water-quality samples would help to determine the prevailing redox condition at these wells. 
Table 23. Oxidation-reduction (redox) categories and processes indicated by water-quality samples collected from wells in the McHenry County groundwater monitoring network, Illinois, 2010.

[Locations of monitoring wells are shown in figure 1. Redox process: CH4gen, methane generation; $\mathrm{Fe}(\mathrm{III})$, iron (III); $\mathrm{Mn}(\mathrm{IV})$, manganese (IV); $\mathrm{NO}_{3}$, nitrate; $\mathrm{O}_{2}$, oxygen; $\mathrm{SO}_{4}$, sulfate]

\begin{tabular}{|c|c|c|c|}
\hline \multirow{2}{*}{$\begin{array}{c}\text { Monitoring } \\
\text { well }\end{array}$} & \multicolumn{2}{|c|}{ Redox } & \multirow{2}{*}{$\begin{array}{l}\text { Aquifer } \\
\text { unit }\end{array}$} \\
\hline & Condition & Process & \\
\hline 14-RIL-S & Oxic & $\mathrm{O}_{2}$ & Haeger-Beverly \\
\hline HUNT-09-03 & Mixed (oxic-anoxic) & $\mathrm{O}_{2}^{2}-\mathrm{Fe}(\mathrm{III})$ & Ashmore Unit \\
\hline 16-GRF-I & Mixed (oxic-anoxic) & $\mathrm{O}_{2}^{2}-\mathrm{Fe}(\mathrm{III})$ & Ashmore Unit \\
\hline 16-GRF-D & Anoxic & $\mathrm{Fe}^{2}(\mathrm{III})$ & Lower Glasford Sand Unit \\
\hline 17-ALG-S & Mixed (oxic-anoxic) & $\mathrm{NO}_{3}-\mathrm{Fe}(\mathrm{III})$ & Yorkville-Batestown Unit \\
\hline 17-ALG-D & Anoxic & $\mathrm{Fe}(\mathrm{III})$ & Shallow Bedrock \\
\hline $43 \mathrm{~N} 8 \mathrm{E}-8.2 \mathrm{c}$ & Mixed (oxic-anoxic) & $\mathrm{O}_{2}-\mathrm{Fe}(\mathrm{III})-\mathrm{SO}_{4}$ & Haeger-Beverly Unit \\
\hline MARS-09-01 & Anoxic & $\mathrm{Fe}(\mathrm{III})$ & Upper Glasford Sand Unit \\
\hline 15-COR-S & Anoxic & $\mathrm{Fe}(\mathrm{III})$ & Haeger-Beverly Unit \\
\hline 15-COR-I & Mixed (oxic-anoxic) & $\mathrm{O}_{2}-\mathrm{Fe}(\mathrm{III})$ & Ashmore Unit \\
\hline 15-COR-D & Anoxic & $\mathrm{Fe}(\mathrm{III})$ & Ashmore Unit \\
\hline $43 \mathrm{~N} 8 \mathrm{E}-3.7 \mathrm{~d}$ & Mixed (oxic-anoxic) & $\mathrm{O}_{2}-\mathrm{Fe}(\mathrm{III})$ & Haeger-Beverly Unit \\
\hline 10-MAR-S & Mixed (oxic-anoxic) & $\mathrm{O}_{2}^{2}-\mathrm{Fe}(\mathrm{III})$ & Haeger-Beverly Unit \\
\hline WAUC-02-12 & Anoxic & $\mathrm{Fe}(\mathrm{III})$ & Lower Glasford Sand Unit \\
\hline 11-SEN-I & Anoxic & $\mathrm{Fe}(\mathrm{III})$ & Ashmore Unit \\
\hline 11-SEN-D & Anoxic & $\mathrm{CH} 4$ gen & Lower Glasford Sand Unit \\
\hline 44N9E-20.7c & Anoxic & $\mathrm{Mn}(\mathrm{IV})$ & Haeger-Beverly Unit \\
\hline MARN-09-02 & Anoxic & CH4gen & Upper Glasford Sand Unit \\
\hline WOOD-08-01 & Mixed (oxic-anoxic) & $\mathrm{O}_{2}-\mathrm{CH} 4$ gen & Ashmore Unit \\
\hline 13-NUN-I & Mixed (oxic-anoxic) & $\mathrm{O}_{2}-\mathrm{Fe}(\mathrm{III})$ & Yorkville-Batestown Unit \\
\hline 13-NUN-D & Mixed (oxic-anoxic) & $\mathrm{O}_{2}-\mathrm{Fe}(\mathrm{III})-\mathrm{SO}_{4}$ & Lower Glasford Sand Unit \\
\hline WAUC-08-13 & Mixed (oxic-anoxic) & $\mathrm{O}_{2}-\mathrm{Fe}(\mathrm{III})$ & Haeger-Beverly Unit \\
\hline $45 \mathrm{~N} 7 \mathrm{E}-32.4 \mathrm{~d}$ & Mixed (oxic-anoxic) & $\mathrm{O}_{2}-\mathrm{Mn}(\mathrm{IV})$ & Haeger-Beverly Unit \\
\hline MHEN-08-01 & Anoxic & $\mathrm{Fe}(\mathrm{III})$ & Haeger-Beverly Unit \\
\hline MARN-09-01 & Anoxic & $\mathrm{Fe}(\mathrm{III})$ & Upper Glasford Sand Unit \\
\hline 7-HRT-S & Anoxic & $\mathrm{Fe}(\mathrm{III})$ & Ashmore Unit \\
\hline 7-HRT-I & Anoxic & CH4gen & Upper Glasford Sand Unit \\
\hline 7-HRT-D & Anoxic & $\mathrm{Fe}(\mathrm{III})$ & Lower Glasford Sand Unit \\
\hline 9-MCH-S & Oxic & $\mathrm{O}_{2}$ & Haeger-Beverly Unit \\
\hline 9-MCH-D & Anoxic & $\mathrm{Fe}(\mathrm{III})$ & Ashmore Unit \\
\hline 8-GRN-I & Oxic & $\mathrm{O}_{2}$ & Ashmore Unit \\
\hline 8-GRN-D & Mixed (oxic-anoxic) & $\mathrm{O}_{2}-\mathrm{Mn}(\mathrm{IV})$ & Lower Glasford Sand Unit \\
\hline HEBR-08-02 & Mixed (oxic-anoxic) & $\mathrm{O}_{2}-\mathrm{Mn}(\mathrm{IV})$ & Haeger-Beverly Unit \\
\hline 45N9E-7.6a & Mixed (oxic-anoxic) & $\mathrm{O}_{2}-\mathrm{Mn}(\mathrm{IV})$ & Haeger-Beverly Unit \\
\hline HARV-09-01 & Anoxic & $\mathrm{Mn}(\mathrm{IV})$ & Ashmore Unit \\
\hline NW-6-45-9 & Suboxic & Suboxic & Haeger-Beverly Unit \\
\hline 1-CHE-S & Anoxic & $\mathrm{Mn}(\mathrm{IV})$ & Ashmore Unit \\
\hline 1-CHE-D & Suboxic & Suboxic & Shallow Bedrock \\
\hline 2-ALD-D & Suboxic & Suboxic & Lower Glasford Sand Unit \\
\hline HEBR-09-03 & Oxic & $\mathrm{O}_{2}$ & Ashmore Unit \\
\hline 4-RCH-S & Oxic & $\mathrm{O}_{2}^{2}$ & Haeger-Beverly Unit \\
\hline 4-RCH-I & Oxic & $\mathrm{O}_{2}^{2}$ & Upper Glasford Sand Unit \\
\hline 4-RCH-D & Oxic & $\mathrm{O}_{2}^{2}$ & Lower Glasford Sand Unit \\
\hline HEBR-08-01 & Oxic & $\mathrm{O}_{2}^{2}$ & Ashmore Unit \\
\hline 3-HEB-I & Suboxic & Suboxic & Ashmore Unit \\
\hline 3-HEB-D & Suboxic & Suboxic & Upper Glasford Sand Unit \\
\hline
\end{tabular}




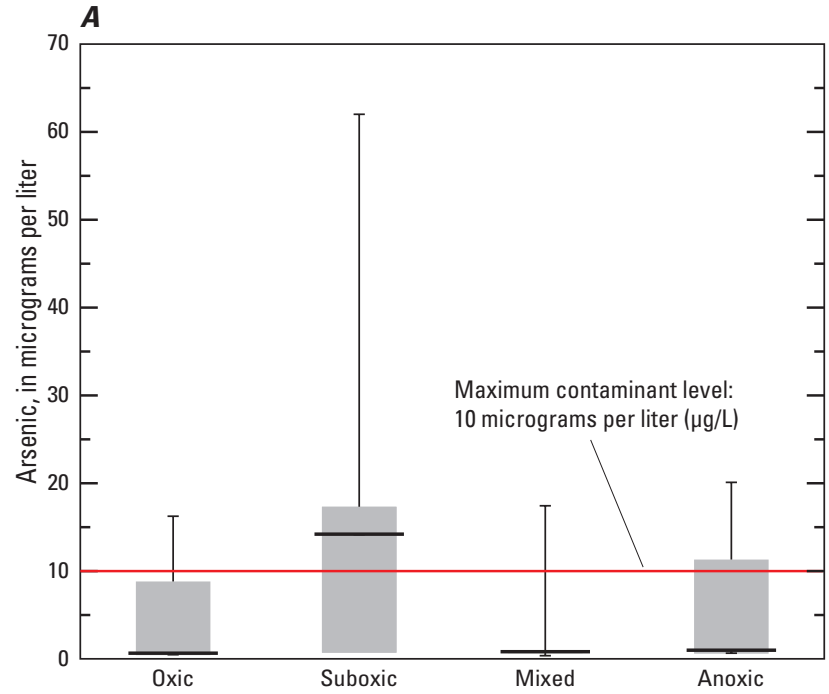

EXPLANATION

Maximum value

75th percentile

50th percentile

(median)

25th percentile

Minimum value
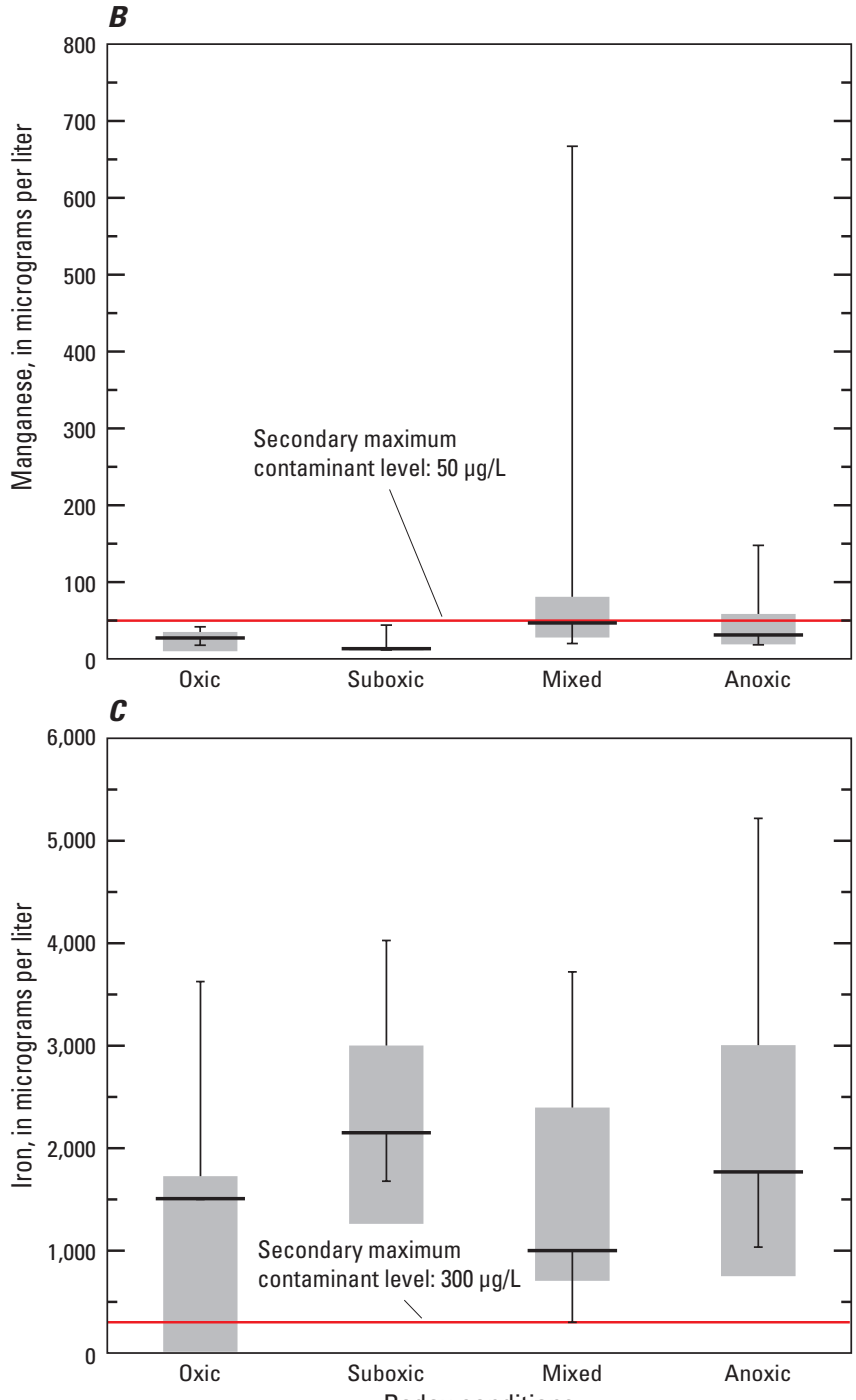

Redox conditions

Figure 29. Distribution between arsenic, manganese, and iron for oxidation-reduction (redox) conditions of oxic, suboxic, mixed, and anoxic in water-quality samples collected from wells in the McHenry County groundwater monitoring network, Illinois, 2010. 


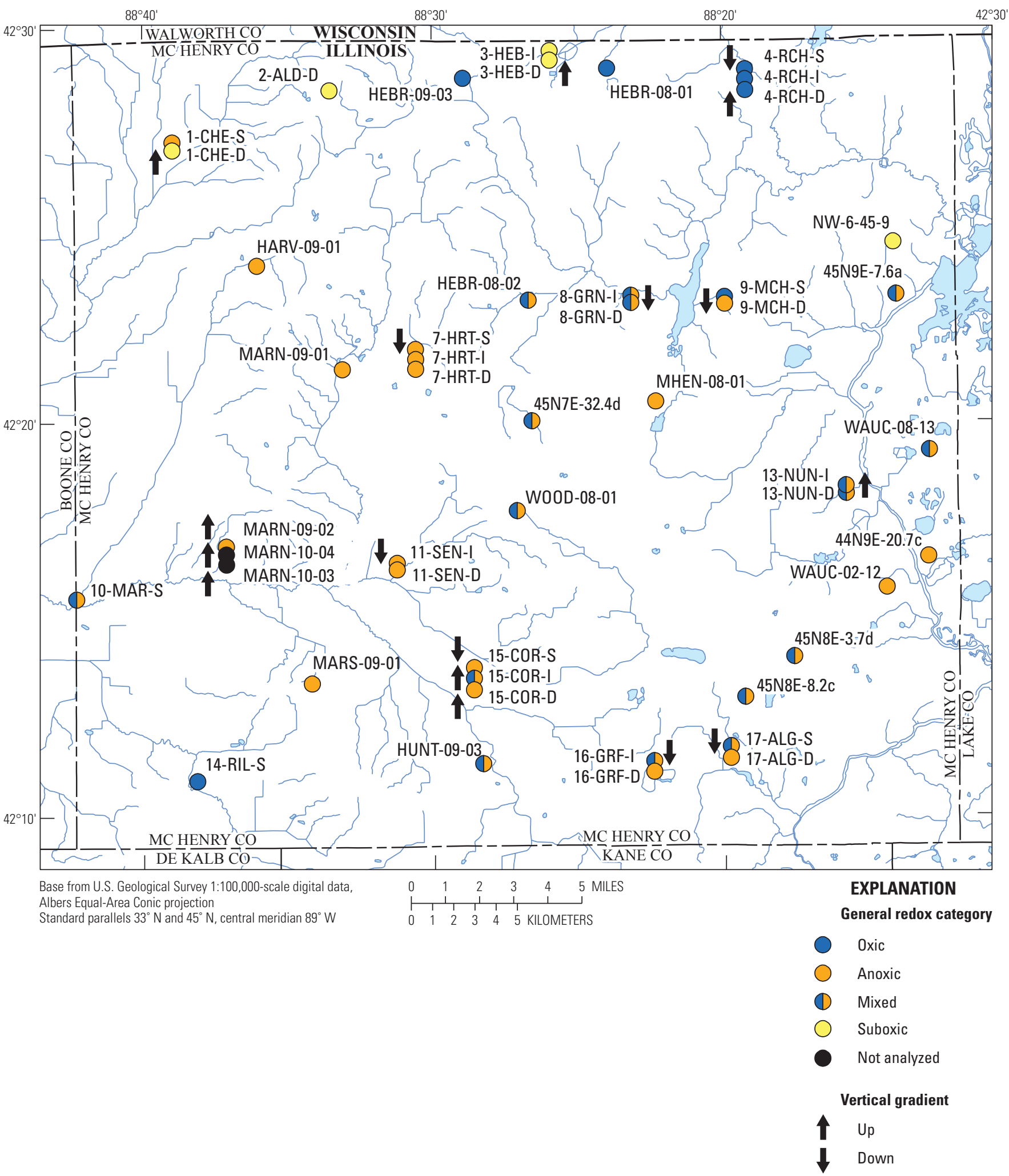

Figure 30. Oxidation-reduction (redox) conditions in wells in the McHenry County groundwater monitoring network, Illinois. 
Numerous sites with mixed redox conditions indicate that the area is hydraulically dynamic and changes potentially with recharge events and seasonal weather patterns. Well WOOD-08-01 is near the headwaters of the Kishwaukee River, and the mixed conditions associated with this well may represent a dynamic system of recharge and discharge areas. Anoxic areas have reducing conditions that could influence the concentration of certain metals. Deep wells that represent anoxic conditions also had arsenic concentrations that generally were higher than those in the wells with oxic conditions.

\section{Chloride Sources}

Natural sources of sodium and chloride in the Midwest occur from atmospheric deposition, and soil-water and rock-water interactions (Panno and others, 2006). However, road salt (de-icers) is one of the primary anthropogenic sources for sodium and chloride (Panno and others, 2006). Sodium chloride $(\mathrm{NaCl})$ is the most commonly used de-icer that is applied to roads and parking lots during winter weather conditions. Magnesium chloride and calcium chloride are also used as road de-icers. Other sources of $\mathrm{NaCl}$ include agricultural chemicals, water softener effluent, wastewater treatment effluent, animal livestock runoff, landfills, and ancient brines (Panno and others, 2006). Chloride generally transports conservatively through groundwater without transforming, dissipating, or interacting with aquifer materials.

\section{Source Analysis of Chloride}

Chloride-bromide (Cl-Br) analysis was used to determine the potential sources of the chloride detected in the groundwater. Bromide, similar to chloride, is a conservative ion that can be deposited from the atmosphere and precipitation and moves into groundwater through recharge (Davis and others, 1998). Anthropogenic sources of bromide are detected in septic tanks, de-icers, agricultural chemicals, pesticides, industrial solvents, water purification, and gasoline additives. Concentrations of bromide in groundwater typically are 40-8,000 times less than those of chloride; thus, small changes in the mass of bromide produce large variations in the ratios of chloride to bromide (Davis and others, 1998). This relation is used to chemically trace the source of chlorides in groundwater. In water-quality samples collected from the MCGMN wells in 2010, chloride concentrations were detected in the range of $0.49-521 \mathrm{mg} / \mathrm{L}$, with a median concentration of $15.2 \mathrm{mg} / \mathrm{L}$ (table 16). Bromide concentrations were detected in the range of 0.01 to $0.12 \mathrm{mg} / \mathrm{L}$, with a median concentration of $0.04 \mathrm{mg} / \mathrm{L}$; no notable outliers were noted in the values (table 16). No values detected at concentrations less than the MRL for bromide were used for the analysis.

The end members and source mixing curves developed from previous studies, as reported in Mullaney and others (2009) for the northern glacial aquifer, were compared with the chloride concentrations and $\mathrm{Cl}-\mathrm{Br}$ ratios from the following sources:

1. All 41 water-quality samples collected in $\mathbf{2 0 1 0}$ (table 16),

2. Water-quality samples collected periodically at six wells (14-RIL-S, 9-MCH-S, 4-RCH-S, 4-RCH-I, 10-MAR-S, and 44N9E-20.7c) with elevated chloride concentrations (greater than $196 \mathrm{mg} / \mathrm{L}$ ) (table 24) for the development of the specific conductance and chloride linear-regression relation. Plotting the results of multiple samplings from the same well could be indicative of variability in sampling approach, changes in flow or recharge conditions through time, and (or) changes in sources through time (although it would be difficult to discern which is the case here).

3. Water-quality samples from five USGS NAWQA wells collected from 2000 to 2010 (table 25).

The chloride concentration to $\mathrm{Cl}-\mathrm{Br}$ ratio for each sample was plotted on the same graph as the binary mixing curves to evaluate if any of the water-quality samples represented mixtures of the various chloride sources and dilute groundwater (Davis and others, 1998; Panno and others, 2005). The proximity of the plotted sample to a line on the mixing curve connecting dilute groundwater and a chloride source end member indicates a possibility of that end member being the potential source of the chloride. 
Table 24. Specific conductance and chloride concentrations for periodic water-quality samples from selected monitoring wells in McHenry County, Illinois, 2009-14.

[Locations of monitoring wells are shown in figure 1. Abbreviations: $\mu \mathrm{S} / \mathrm{cm}$, microsiemens per centimeter; $\mathrm{mg} / \mathrm{L}$, milligrams per liter]

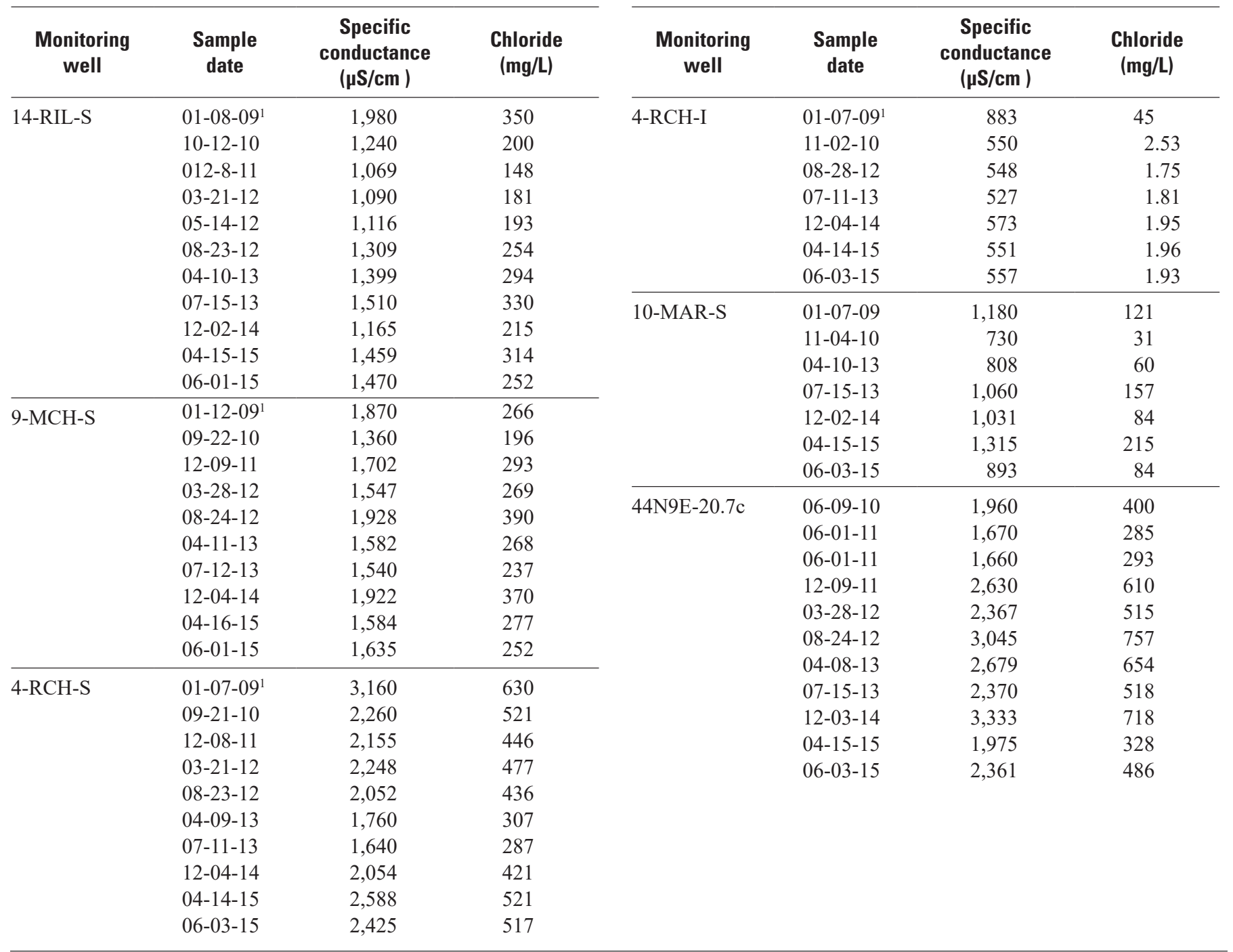

\footnotetext{
${ }^{1}$ Samples obtained in 2009 for specific conductance and chloride concentrations are from AECOM (2009).
} 
Table 25. Chloride and bromide concentrations for periodic water-quality samples from five National Water-Quality Assessment program wells in McHenry County, Illinois, 2000-10.

[Locations of monitoring wells are shown in figure 1. All values are in milligrams per liter. $<$, less than]

\begin{tabular}{cccc}
\hline $\begin{array}{c}\text { Monitoring } \\
\text { well }\end{array}$ & $\begin{array}{c}\text { Sample } \\
\text { date }\end{array}$ & Chloride & Bromide \\
\hline 43N8E-8.2c & $06-08-00$ & 87.2 & 0.07 \\
& $07-13-10$ & 197 & 0.06 \\
43N8E-3.7d & $04-20-00$ & 308 & 0.10 \\
& $07-13-10$ & 149 & 0.06 \\
44N9E-20.7c & $04-19-00$ & 90.1 & 0.08 \\
& $06-25-02$ & 229 & 0.11 \\
& $06-13-05$ & 395 & 0.09 \\
& $07-10-07$ & 480 & 0.08 \\
& $08-04-09$ & 525 & 0.07 \\
& $06-09-10$ & 400 & 0.06 \\
& $06-01-11$ & 293 & 0.06 \\
& $12-09-11$ & 610 & 0.08 \\
& $03-28-12$ & 515 & 0.08 \\
& $08-24-12$ & 757 & 0.23 \\
& $04-08-13$ & 654 & 0.08 \\
& $07-10-13$ & 518 & 0.08 \\
& $12-03-14$ & 718 & $1<0.075$ \\
& $04-13-15$ & 328 & 0.07 \\
& $05-22-00$ & 8.11 & 0.03 \\
$45 N 9 E-7.6 a$ & $07-12-12$ & 75.4 & 0.02 \\
& $05-09-00$ & 153 & 0.10 \\
& $06-07-00$ & 159 & 0.07 \\
& $06-09-10$ & 204 & 0.06 \\
\hline
\end{tabular}

${ }^{1}$ Not included in the chloride bromide ratio analysis.

The results of the $\mathrm{Cl}-\mathrm{Br}$ analysis generally indicate that various chloride sources have affected groundwater throughout the county (fig. 31). The likely sources for many of the water-quality samples plot either on or between the mixing curves for dilute groundwater/road-salt and dilute groundwater/water softener. Likely sources for numerous water-quality samples also plot on the mixing curve between sewage and road salt or on the mixing curve between dilute groundwater and sewage. Monitoring well 10-MAR-S was originally considered a background well based on initial chloride concentrations $(31 \mathrm{mg} / \mathrm{L})$ detected during the 2010 sampling period. However, subsequent sampling (table 24) indicated that concentrations of chloride from well 10-MAR-S actually vary between 60 and $215 \mathrm{mg} / \mathrm{L}$. The sources of the chloride for this well, as indicated by the $\mathrm{Cl}-\mathrm{Br}$ ratio analysis, possibly are sewage and road salt mixtures and (or) sewage.

There is considerable overlap between sites that plot along or between the road-salt mixing curve and the water-softener mixing curve. The overlap is a common occurrence in end member signatures for road salt and septic/ sewage, particularly if water softener discharges to the septic system (Panno and others, 2006), which makes it difficult to discern between the sources. Sources may be inferred by considering the potential for the source at each individual site (fig. 31). For example, sample ratios from monitoring wells 14-RIL-S or 4-RCH-S near or on the road-salt mixing curve, but overlap onto the water-softener mixing curve; however, neither are likely to have water softener inputs because there are few or no upgradient sources at these sites. The overlap may be because the end members were developed from varying sources throughout the State of Illinois and may not have been specific to the road-salt mixtures applied throughout McHenry County. There also is consideration in urban settings that may have the possibility of both road salt and sewage sources from leaky stormwater and (or) leaky sanitation sewers from the discharge coming from residential homes. Ratios from many of the urban NAWQA monitoring wells (44N9E-20.7c, 43N8E-8.2c, 43N8E-3.7d, 45N9E-7.6a) plot between or on curves for road salt, road salt and sewage, or water softener. All these curves are possible sources; therefore, determining the exact source requires additional analysis or investigation. 


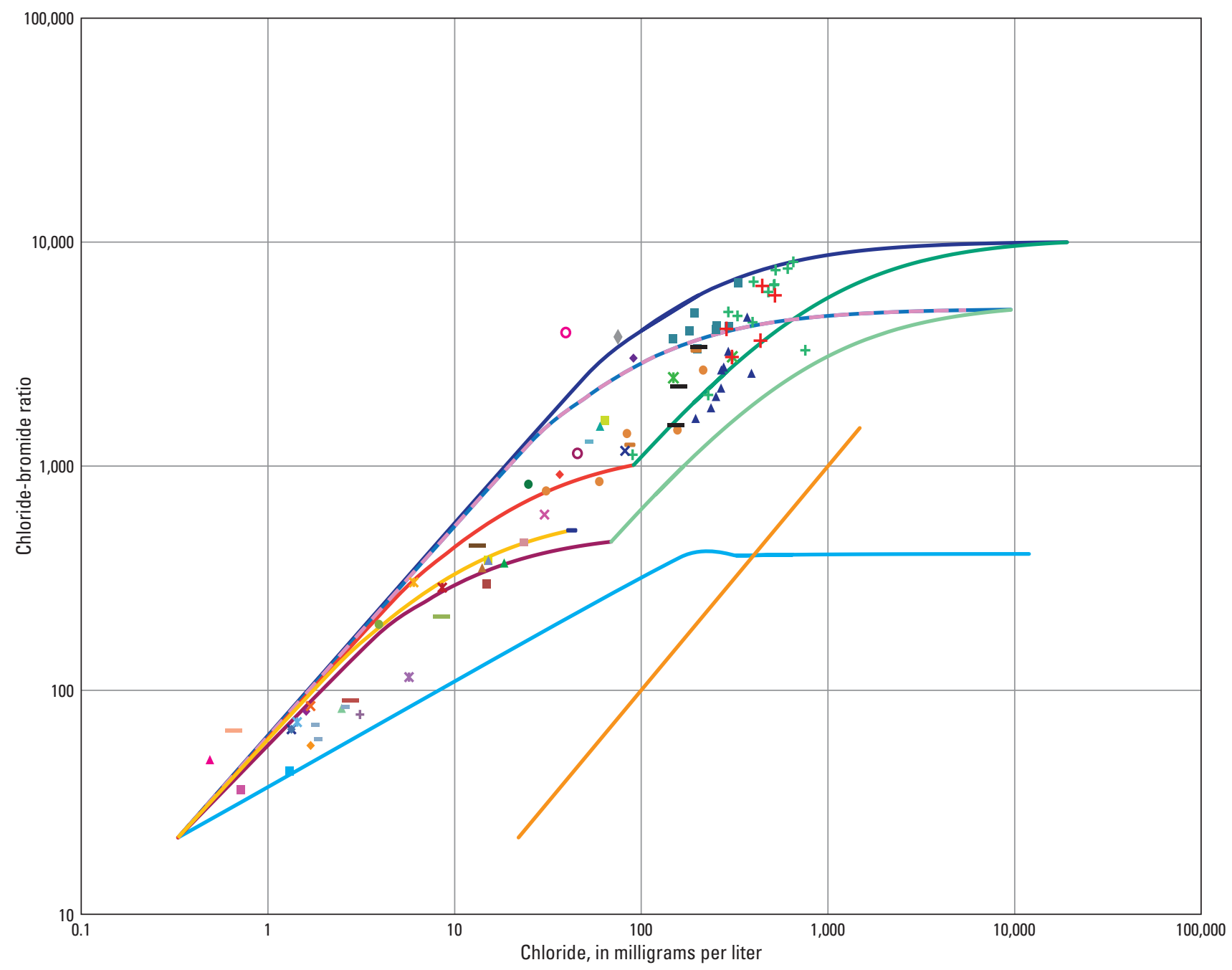

\section{EXPLANATION}

Well

\begin{tabular}{|c|c|c|c|}
\hline 14-RIL-S & • 11-SEN-D & $\triangle$ 9-MCH-S & $+4-\mathrm{RCH}-\mathrm{S}$ \\
\hline$+44 N 9 E-20.7 c$ & MARN-09-02 & * 9-MCH-D & $=4-\mathrm{RCH}-\mathrm{I}$ \\
\hline - 17-ALG-D & A W00D-08-01 & O 8-GRN-I & $=4-\mathrm{RCH}-\mathrm{D}$ \\
\hline $43 N 8 E-8.2 c$ & × 13-NUN-I & $+8-G R N-D$ & HEBR-08-01 \\
\hline MARS-09-01 & * 13-NUN-D & HEBR-08-02 & 3-HEB-I \\
\hline 15-COR-S & - WAUC-08-13 & $-45 \mathrm{~N} 9 \mathrm{E}-7.6 \mathrm{a}$ & $\triangle 3$-HEB-D \\
\hline 15-COR-I & 45N7E-32.4d & - HARV-09-01 & $\Delta$ HUNT-09-03 \\
\hline$\times 15-$ COR-D & - MHEN-08-01 & NW-6-45-9 & $\times$ 16-GRF-I \\
\hline * 43N8E-3.7d & - MARN-09-01 & $\triangle 1$-CHE-S & * 16-GRF-D \\
\hline 10-MAR-S & 7-HRT-S & $\times$ 1-CHE-D & O 17-ALG-S \\
\hline WAUC-02-12 & - 7-HRT-I & * 2-ALD-D & \\
\hline - 11-SEN-I & $\triangle \quad 7-H R T-D$ & - HEBR-09-03 & \\
\hline
\end{tabular}

Figure 31. Binary mixing curves for various chloride-to-bromide ratio sources and individual well chloride-to-bromide ratios represented by McHenry County groundwater monitoring network and National Water-Quality Assessment wells, McHenry County, Illinois, 2000-15. Chloride end members and mixing curves are from Mullaney and others (2009). 
The Cl-Br results in each aquifer unit also were plotted in relation to the mixing curves (fig. 32), which shows that the ratios representing wells tapping the shallow Haeger-

Beverly Unit primarily plot along the dilute groundwater and road-salt mixing curve and along the dilute groundwater and water-softener mixing curve. Some Haeger-Beverly Unit well ratios also are indicative of a sewage source, but a sewage source predominately is associated with the Ashmore Unit.

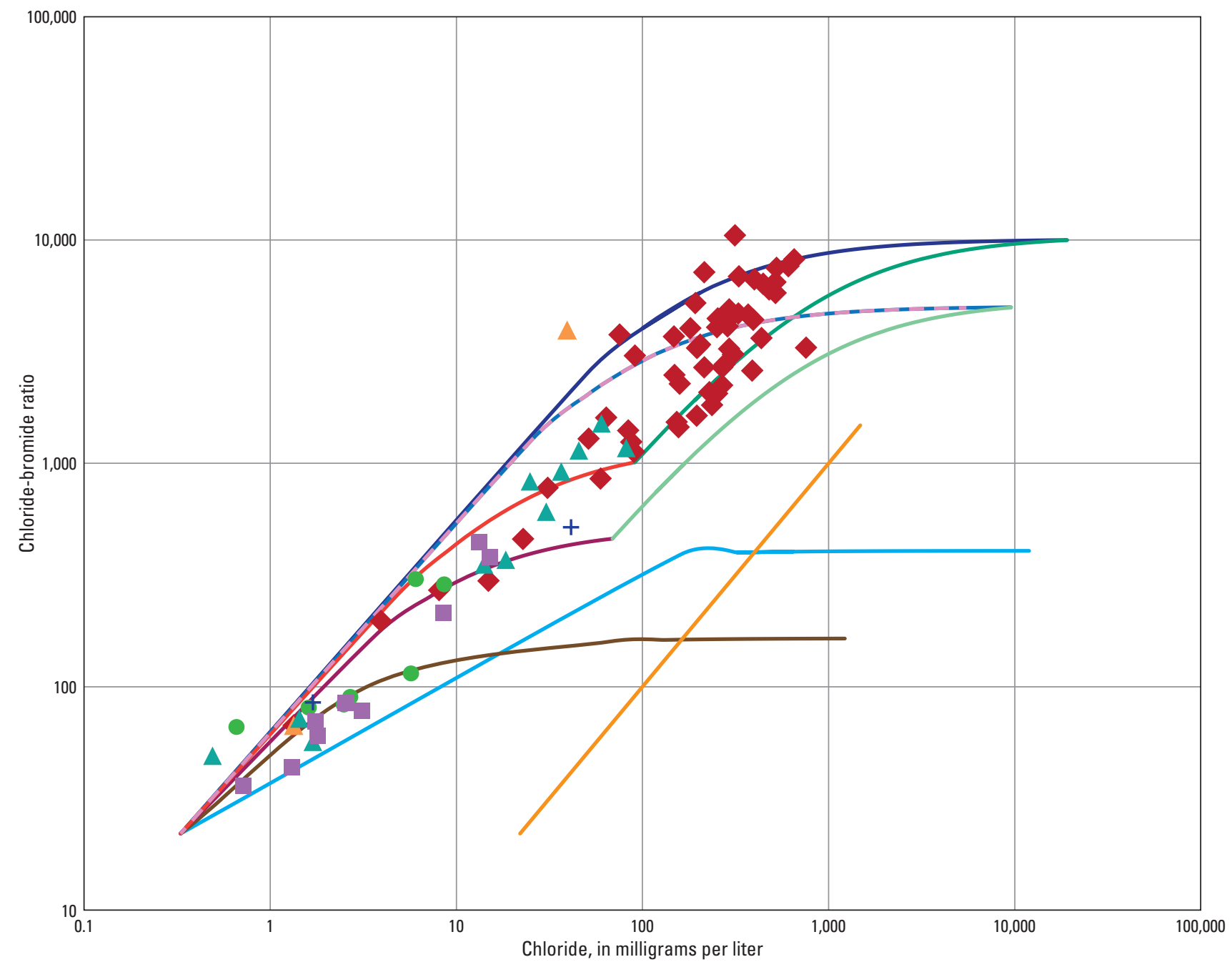

EXPLANATION

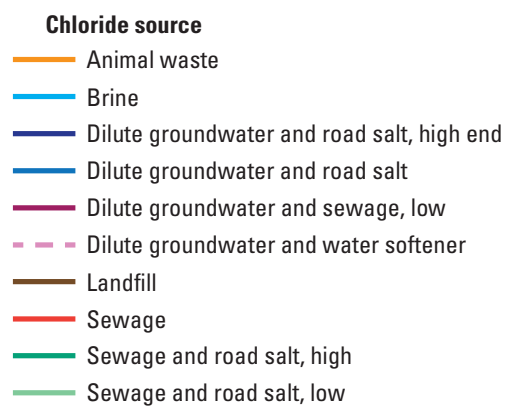

Aquifer Unit

- Haeger-Beverly

Y Yorkville-Batestown

$\Delta$ Ashmore Sand

- Upper Glasford Sand

- Lower Glasford Sand

+ Shallow bedrock

Figure 32. Binary mixing curves for various chloride-to-bromide ratios sources in aquifer units represented by the McHenry County groundwater monitoring network and National Water-Quality Assessment wells, McHenry County, Illinois, 2000-15. Chloride end members and mixing curves are from Mullaney and others (2009). 
Monitoring wells were subdivided into urban or agricultural categories to determine which category plotted along which mixing curve. Monitoring well sites were mixed with urban and agricultural land uses surrounding the well. Urban wells were determined by calculating the percentage of road density based on 2014 TIGER/Line ${ }^{\circledR}$ shapefiles for McHenry County (U.S. Census Bureau, 2014). Lines were converted to a $30-\mathrm{m}$ grid that matched the National Land Cover Dataset (NLCD) and the number of road segments and percentage of road density were determined from the $500-\mathrm{m}$ $(1,640-\mathrm{ft})$ radius for each well by using the NLCD. Urban wells primarily plot along the dilute groundwater and road salt-high end and dilute groundwater and water softener curves (fig. 33). Agricultural wells clustered along the source mixing curves for sewage, and sewage and road-salt mixing curves. Some overlap occurred among the mixed land uses between urban and agricultural and the various sources of chloride.

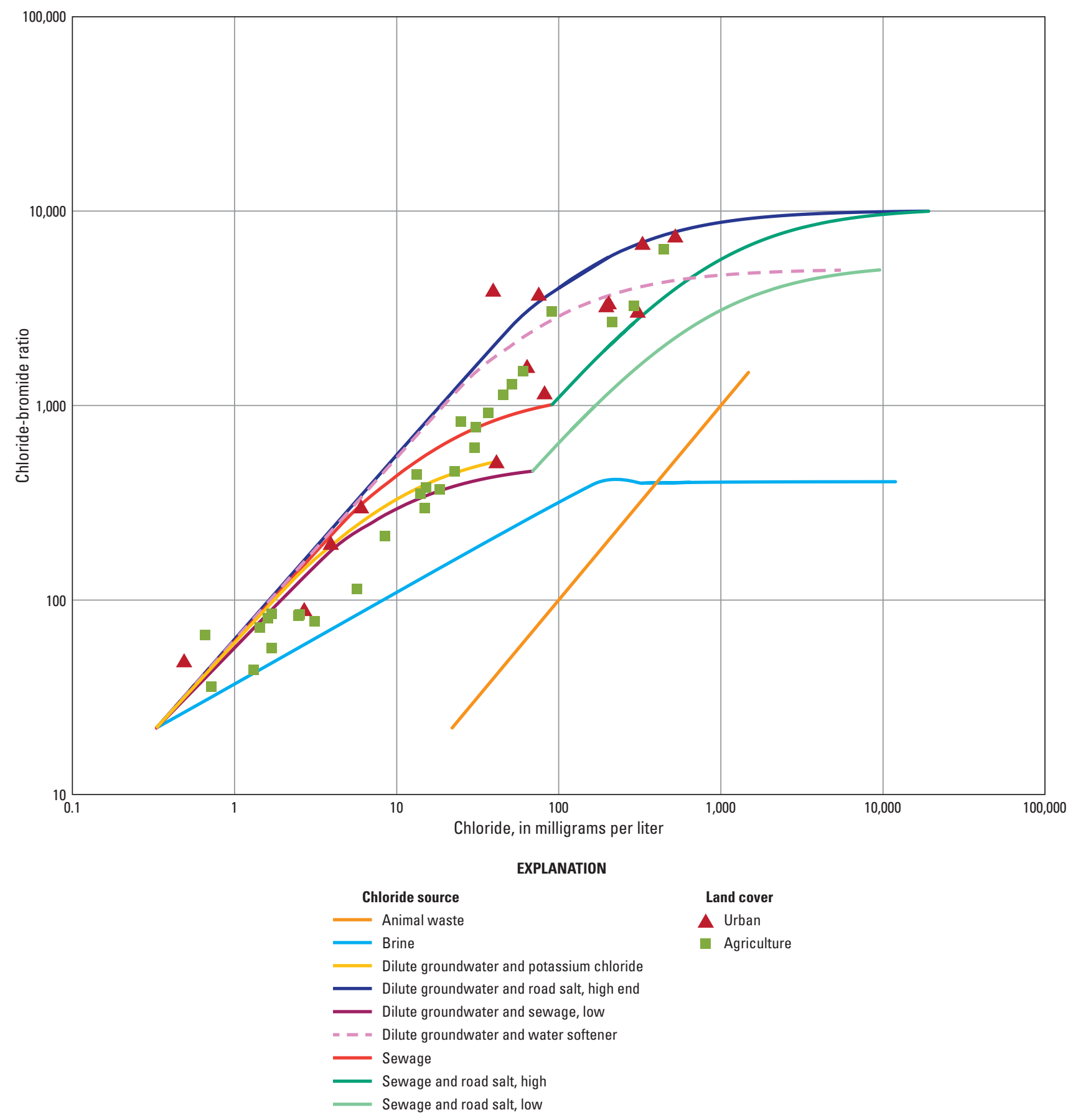

Figure 33. Binary mixing curves for chloride-to-bromide (Cl-Br) ratios for urban and agriculture land cover represented by the McHenry County groundwater monitoring network and National Water-Quality Assessment wells, McHenry County, Illinois, 2000-15. Chloride end members and mixing curves modified from Mullaney and others (2009). 


\section{Time-Series Analysis of Chloride Concentrations}

Monitoring seasonal trends of chloride at a few monitoring wells with elevated concentrations helped identify a few factors (geology and weather) that influence concentrations and potential fate and transport of this anthropogenic constituent. Seasonal trends of chloride were determined from continuous-specific conductance and water level data at select monitoring wells. The relation of specific conductance to chlorides is proportional, with greater specific conductance values associated with greater chloride values.

Specific conductance is a measure of the ability of water to transmit an electrical current (U.S. Geological Survey, 2016e). The regression analysis of specific conductance and chloride data from four of the wells (14-RIL-S, 9-MCH-S, 4-RCH-S, 10-MAR-S) resulted in equations with r-squared values of 0.73 or higher (fig. 34). A coefficient of determination (r-squared value) of 0.73 indicates that 73 percent of the variation in chloride concentration is explained by the linear equation. Analysis of the data at well 44N9E-20.7c resulted in a poor relation, and a quality regression equation could not be developed because there were substantial differences (at times) between specific conductance readings from the transducer equipped with a sensor and values obtained during sampling from the multi-parameter sonde.

Overall, the use of specific conductance as a surrogate for chloride generally is acceptable to very good (r-squared values ranged from 0.73 to 0.90 ). Although not evident from the turbidity values, there are certain locations (wells 9-MCH-S, 4-RCH-S, 44N9E-20.7c) with high clay content that could produce inaccurate or unacceptable regression equations. Other methods, such as developing a chloride concentration and specific conductance relation through automated-interval sampling methods (Anderson and Rounds, 2010), may be necessary to improve regression results.

Continuous chloride concentrations estimated using regression equations, and groundwater elevation (water level) data for the four monitoring wells for which the regression equations were developed, are shown in figure 35 . The estimated chloride concentrations varied by as much as $120-225 \mathrm{mg} / \mathrm{L}$ from year to year in most of the monitoring wells. The horizontal hydraulic conductivity - the resistance of a rock or sediment to flow through pore spaces or fractures (Freeze and Cherry, 1979) —of the aquifer unit tapped by each well and the saturated thickness of the unit play a role in controlling the concentrations of chlorides measured throughout the year. The saturated aquifer thickness and horizontal hydraulic conductivity of the aquifer unit at the selected well sites are shown in table 26. Elevated hydraulic conductivities (213 and $369 \mathrm{ft} / \mathrm{d}$, respectively) are present at wells 10-MAR-S and 14-RIL-S, and aquifer thicknesses are 26 and $18 \mathrm{ft}$, respectively (AECOM, 2009). At wells 10-MAR-S and 14-RIL-S, chloride concentrations approximate the trend of the water levels. However, chloride concentrations in well 14-RIL-S remained generally
A. 14-RIL-S

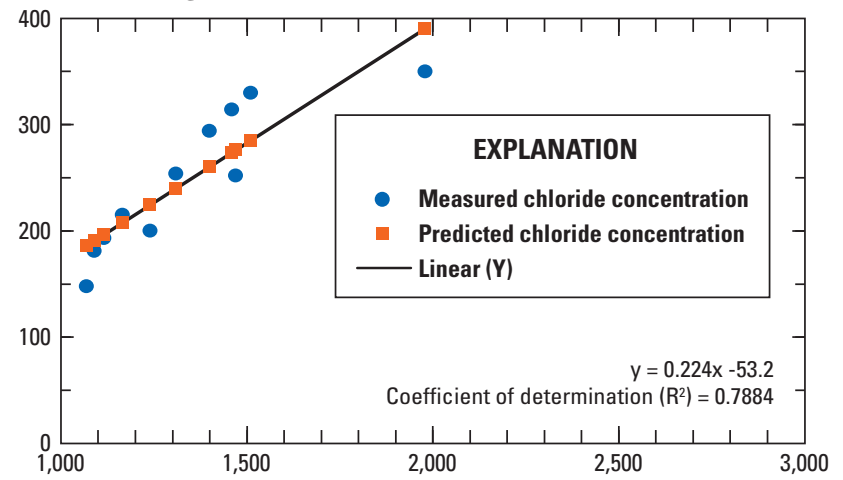

B. 9-MCH-S

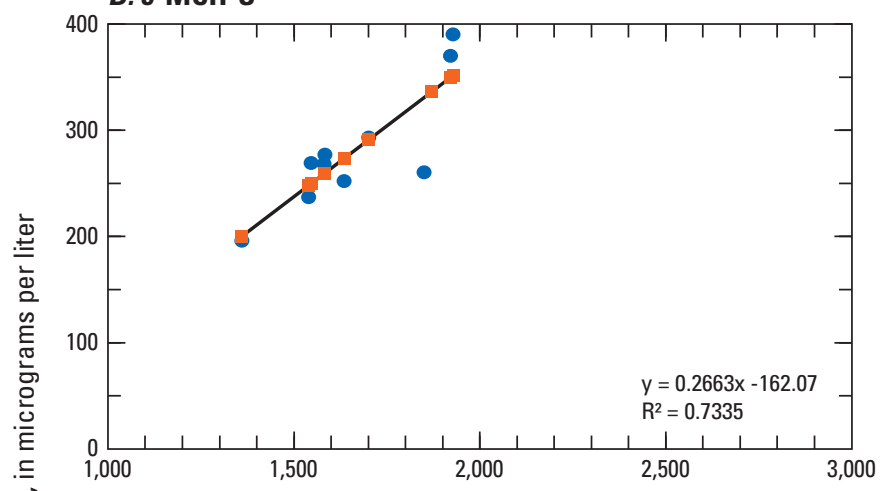

C. 4-RCH-S

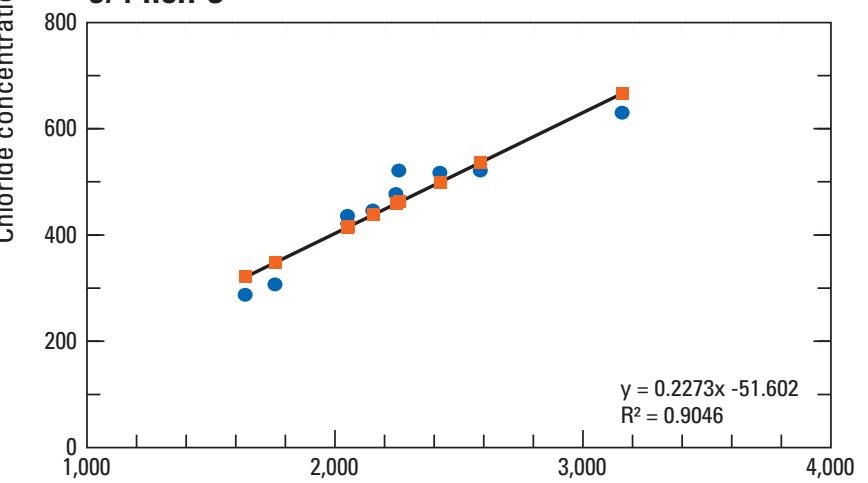

D. 10-MAR-S

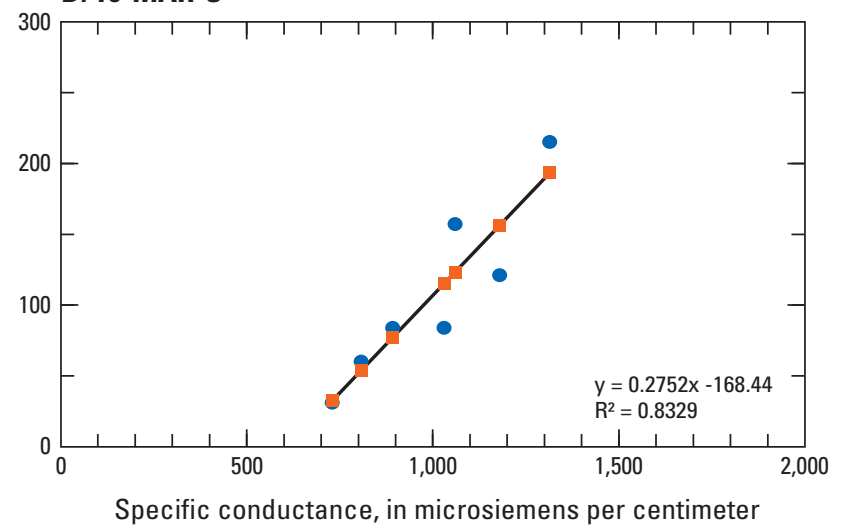

Figure 34. Linear regressions and equations for chloride-specific conductance surrogate at selected wells in the McHenry County groundwater monitoring network, Illinois, 2011-14. 
unchanged during about May-September 2011, and again during August-November 2013, when water levels declined (fig. 35). Periods of recharge, as suggested by rapidly rising water levels, commonly are associated with peaks in chloride concentrations. Both wells also are near a stream (500-1,300 ft from stream), and groundwater likely is discharging to the nearby stream. The chloride changes throughout the year show that precipitation and runoff readily infiltrate the ground, but dissolved constituents in the recharge, such as chlorides associated with road salt, are not stored or concentrated in the aquifer. Instead, the affected groundwater seemingly discharges quickly to the nearby streams.

A. 14-RIL-S

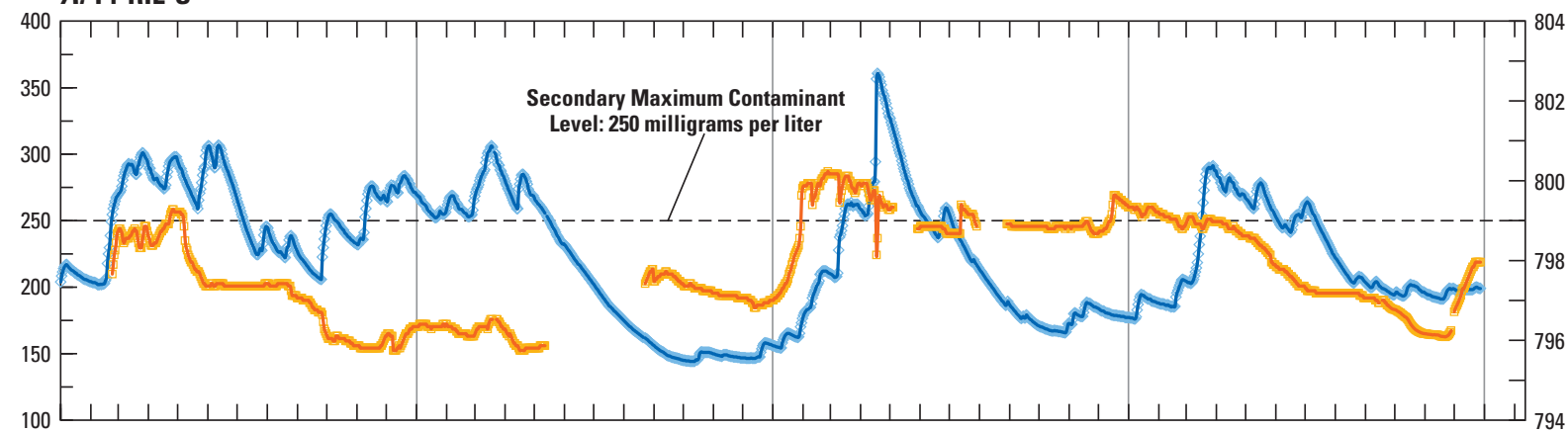

B. 10-MAR-S

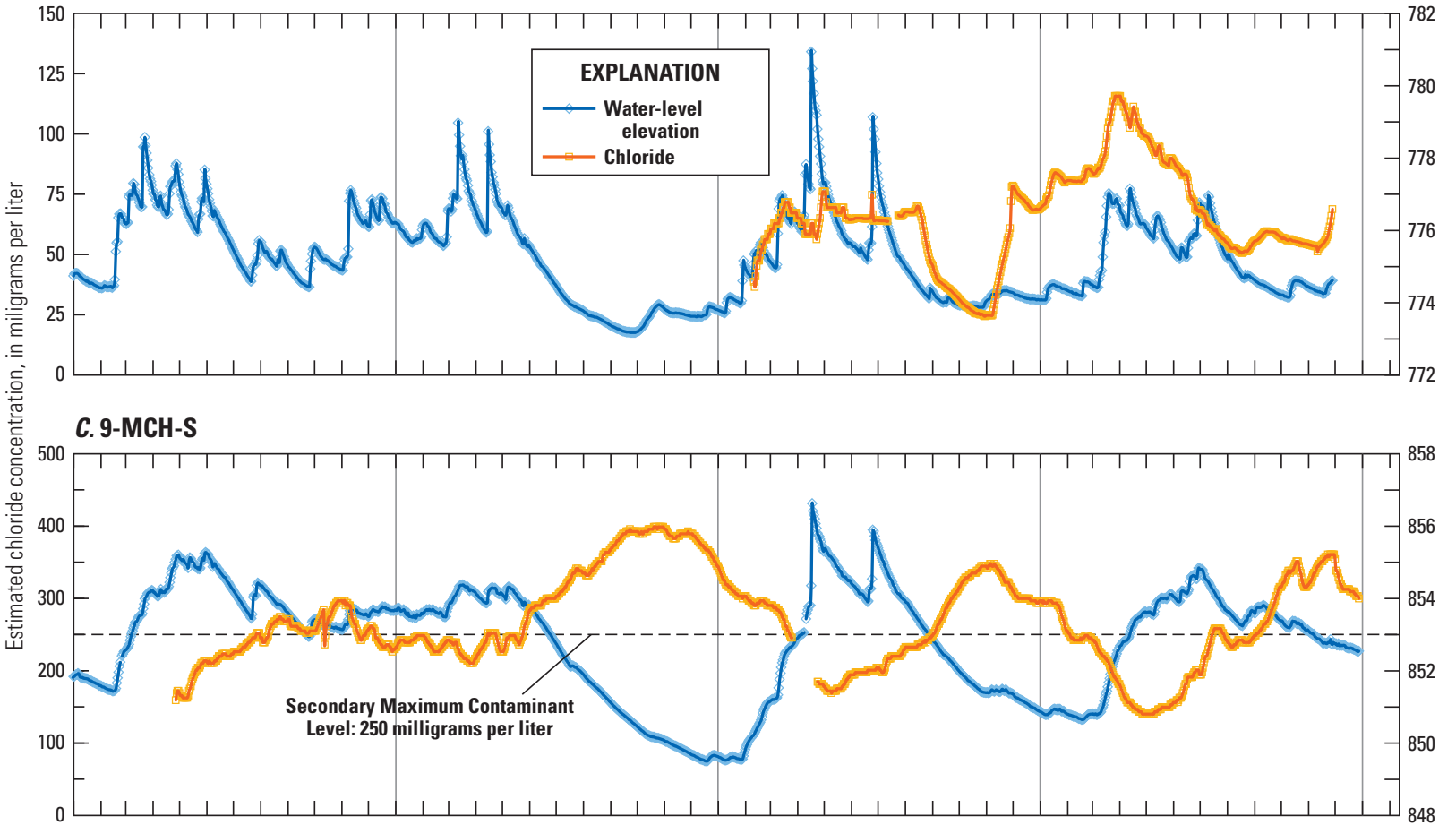

D. 4-RCH-S

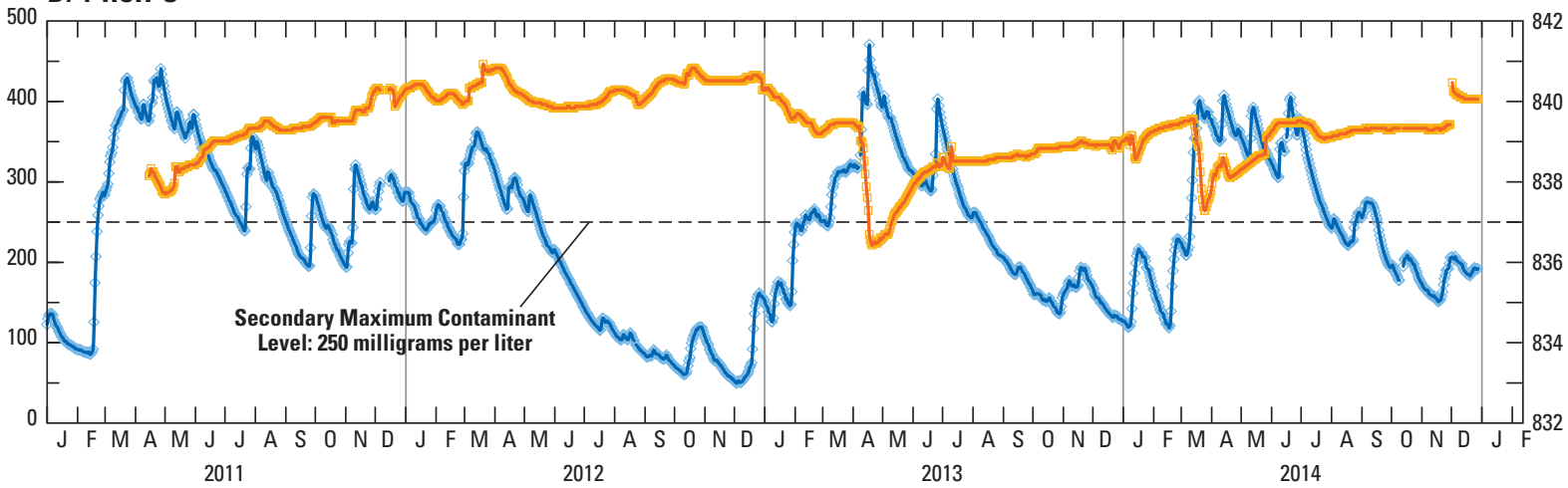

Figure 35. Estimated chloride concentrations from continuous specific-conductance and water-level elevation data for selected wells in the McHenry County groundwater monitoring network, Illinois, 2011-14. 
Table 26. Saturated thickness of aquifer and horizontal hydraulic conductivity measured for selected wells in the McHenry County groundwater monitoring network, Illinois.

[Horizontal hydraulic conductivities obtained from slug tests performed and reported by AECOM (2009). Abbreviations: ft, foot; ft/d, foot per day]

\begin{tabular}{lcc}
\hline $\begin{array}{c}\text { Monitoring } \\
\text { well }\end{array}$ & $\begin{array}{c}\text { Saturated thickness } \\
\text { of the aquifer } \\
\text { (ft) }\end{array}$ & $\begin{array}{c}\text { Horizontal hydraulic } \\
\text { conductivity } \\
\text { (ft/d) }\end{array}$ \\
\hline 14-RIL-S & 18 & 369 \\
10-MAR-S & 26 & 213 \\
9-MCH-S & 10 & 31.2 \\
4-RCH-S & 5 & 1.13 \\
\hline
\end{tabular}

Conversely, monitoring wells 9-MCH-S and 4-RCH-S are screened in relatively thin saturated aquifers (10 ft or less thick) with relatively low hydraulic conductivities (about 31.2 and $1.13 \mathrm{ft} / \mathrm{d}$, respectively [AECOM, 2009]). Both wells are within 800 and $970 \mathrm{ft}$ of a stream and groundwater may be discharging into these streams. Monitoring well 9-MCH-S showed a seasonal pattern of high chloride concentrations during the late summer and autumn, coinciding with the seasonal decline in groundwater levels. This period was followed by lower chloride concentrations in spring as the groundwater levels rose (fig. 35). This pattern is similar to well 4-RCH-S, which also showed high concentrations of chloride during the periods of low groundwater levels. The chloride concentrations at this well remain largely steady with only slight increases or decreases. However, during some periods of substantial recharge indicated by rapidly rising water levels, the chloride concentrations decrease as the newly recharging waters flush the aquifer. The comparatively thin saturated thicknesses and lower horizontal hydraulic conductivity of these aquifer locations allows the storage and concentration of chlorides. The concentrations of chlorides throughout each year for wells 9-MCH-S and 4-RCH-S were greater than the SCML of $250 \mathrm{mg} / \mathrm{L}$ and ambient water-quality criteria of $230 \mathrm{mg} / \mathrm{L}$, except during periods of rapidly rising water levels during spring.

All the monitoring wells where chloride concentrations were estimated based on specific conductance regression analysis had concentrations that generally, or at some time, exceeded the 230-mg/L EPA criterion for aquatic chronic toxicity (relevant when the groundwater eventually discharges to a stream, lake, or wetland), except well 10-MAR-S. These wells are shallow (less than $25 \mathrm{ft}$ below land surface) and represent the uppermost part of the aquifer that is likely to be a primary component of base flow entering nearby streams, lakes, or wetlands, contributing to the total chloride load. The SMCL of $250 \mathrm{mg} / \mathrm{L}$ for chloride also generally was, or at some time, exceeded. When the shallow groundwater discharges to nearby streams and wetlands, the elevated chloride concentrations can potentially reduce aquatic diversity by artificially selecting for salt-tolerant species (Kelly and others, 2009).
The vertical transport of chloride at these sites was not evaluated with continuous monitoring. However, periodic monitoring by USGS at well 4-RCH-I showed substantially lower (than well 4-RCH-S) chloride concentrations ranging from 1.75 to $2.53 \mathrm{mg} / \mathrm{L}$ (table 24), with a median concentration of $1.94 \mathrm{mg} / \mathrm{L}$, and had no increase in chloride concentrations. The $76 \mathrm{ft}$ of clay overlying the screened interval at 4-RCH-I acts as a confining unit of low permeability, which reduces infiltration of the chloride into the lower aquifer unit. The 2010 water-quality samples collected at well 9-MCH-D also had chloride concentrations $(1.44 \mathrm{mg} / \mathrm{L})$ substantially less than at the shallow nested well (9-MCH-S). A 117-ft clay layer overlies the screened interval of 9-MCH-D probably acting as a low permeable barrier to vertical transport of chloride. These wells also are weakly interconnected based on the analysis previously shown in the "Degree of Interconnection" section of this report.

Continuous chloride data using specific conductance as a surrogate appears to be an effective means for determining the fate and transport of chloride concentrations within the groundwater. Such data can provide water managers and the public the information needed to understand potential chloride concentrations in groundwater that is discharging to streams as base flow. In addition, continuous chloride data can be used to assess the utility of current best management practices aimed at reducing the amount of chloride entering the groundwater system.

\section{Comparisons to Conditions in 1979}

The USGS previously conducted an investigation of the sand and gravel aquifers by obtaining water levels from 131 residential supply wells; 25 of the wells also were sampled for water quality (Nicholas and Krohelski, 1984). Water levels from two periods (May 1979 and May 2014; fig. 36) were compared by plotting the water levels onto two separate potentiometric surface maps using Surfer $^{\circledR}$ software. The most recent and comparable (May 2014) water-level data were used in the potentiometric surface map representing the present study. The May 2014 water-level data included only wells greater than $50 \mathrm{ft}$ deep because the residential-well data from the previous study did not include wells with depths less than $50 \mathrm{ft}$. Screening by well depth (removing monitoring wells less than $50 \mathrm{ft}$ deep) reduced the number of water-level measurements to 31 monitoring points for the May 2014 dataset. All 131 water levels from the 1979 dataset predominately were obtained in May or during spring and were used to create the potentiometric surface map. Only 25 of the 131 residential wells from Nicholas and Krohelski (1984, pl. 1) are shown in figure 36A. The two separate potentiometric surface maps were compared to assess locations where changes in water levels may have occurred. 


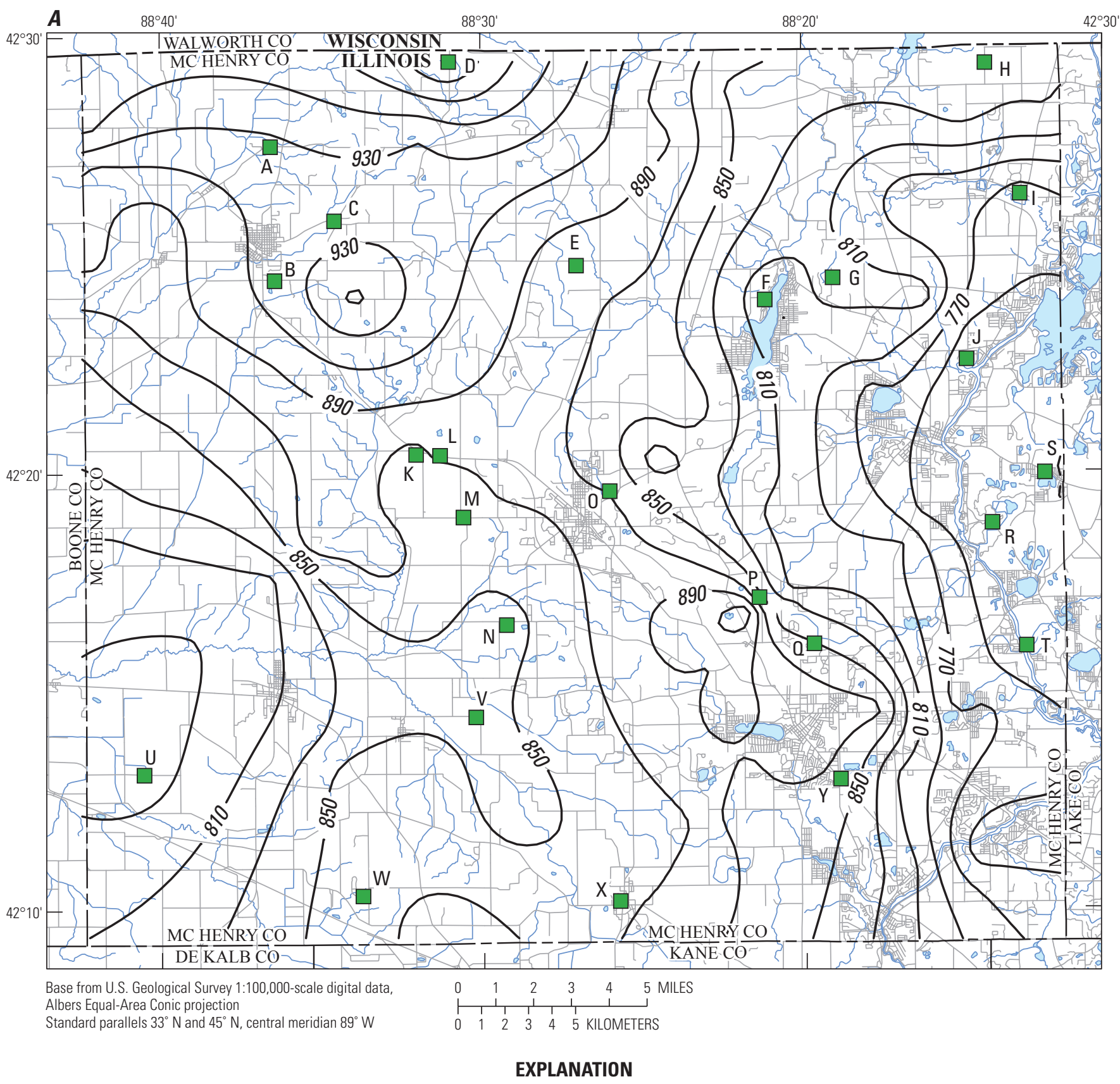

-850 Water-level contour-Contour interval 20 feet
$\square$ A Residential well sampled in 1979

Figure 36. (A) residential supply wells (25 of the 131) from the 1979 dataset (Nicholas and Krohelski, 1984), and (B) deep aquifer units (greater than 49 feet below water surface) represented by corresponding McHenry County groundwater monitoring network, Illinois, May 2014. 


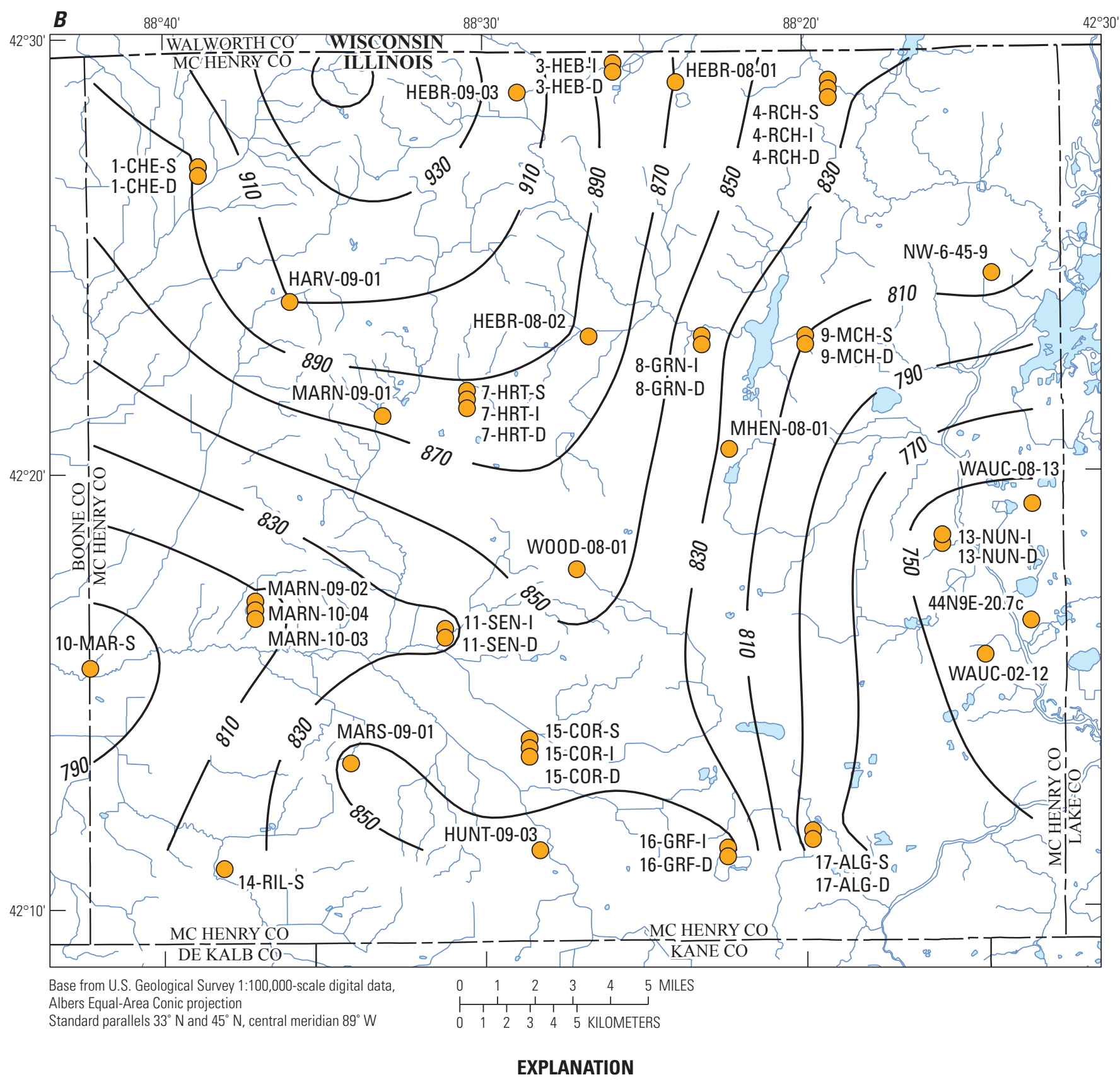

\section{- 850 Water-level contour-Contour interval 20 feet \\ O1-CHE-S Monitoring well sampled in 2010}

Figure 36.-Continued 
The water levels were carefully compared given that the two sets of data also are from different types of well construction and at different locations. Residential wells are designed to maximize the amount of water that enters the well and commonly are constructed with large screened intervals $(10 \mathrm{ft}$ or more) that may cross between two different aquifer units. In contrast, the monitoring wells in the MCGMN have screened intervals of $5 \mathrm{ft}$ and are open to a specific aquifer unit. The two datasets also applied different vertical datums. The 1979 dataset used the North American Vertical Datum of 1929 (NAVD 29), and the 2014 dataset used NAVD 88. These two different datums add a plus-or-minus difference of one contour interval $(10 \mathrm{ft})$.

Water-level changes between 20 and $40 \mathrm{ft}$ were observed in different locations at the contour intervals in the central (WOOD-08-01) and southeastern (16-GRF-I/D, 17-ALG-D, 13-NUN-I/D) parts of McHenry County (fig. 36B). The changes in water levels are shown as substantial, but likely due to differences in datum, well types, and location and number of control points. The areas with the noted differences in water levels shown on the potentiometric surface maps are consistent with the difference between predevelopment and present-day water levels identified by the groundwater model of Meyer and others (2013).

Water-quality samples collected from the 25 residential wells sampled in 1979 were analyzed for major ions and nutrients. Those water-quality data from residential wells sampled from April 30, 1979 to May 3, 1979 (from the Nicholas and Krohelski [1984] study) and the data from monitoring wells sampled from June 2010 to November 2010 of this study are considered as two separate datasets; the statistical application of the Wilcoxon rank sum test (Helsel, 2005) was applied to determine if the differences between means of the two sets of data were significant. The sampled wells in the Nicholas and Krohelski (1984) study generally were deeper (greater than $50 \mathrm{ft}$ below land surface) than those in the 2010 study presented here. Water-quality data collected in 2010 from monitoring wells less than $50 \mathrm{ft}$ in depth were not included in the graphical and statistical comparisons of water quality presented here. The locations of the wells sampled in both 1979 and 2010 water-quality analyses are presented in figure 37.

Different types of well construction may affect the overall accuracy of this water-quality comparison. Residential wells with larger screened intervals or open intervals may cause some mixing of the water-quality signature between the aquifer units. Monitoring wells generally have shorter screened intervals and the water-quality samples usually are well representative of the single aquifer unit in which they are screened.

A summary of the medians for the major ions and nutrients for the 1979 and 2010 datasets is presented in table 27. Increases were notable for specific conductance, sodium, chloride, alkalinity, sulfate, and total dissolved solids. Specific conductance and total dissolved solids were the only two constituents with a significant difference ( $p$-value less than 0.05) according to the Wilcoxon rank sum test. Chloride concentrations were nearly significantly different (p-value equal to 0.054) in wells greater than $50 \mathrm{ft}$ deep.

Table 27. Median water-quality data from wells in the McHenry County groundwater monitoring network, Illinois, 1979 and 2010.

[Water-quality data for 1979 from Nicholas and Krohelski (1984). Abbreviations: $\mathrm{CaCO}_{3}$, calcium carbonate; ${ }^{\circ} \mathrm{C}$, degrees Celsius; $\mu \mathrm{S} / \mathrm{cm}$, microsiemens per centimeter at 25 degrees Celsius; $\mathrm{mg} / \mathrm{L}$, milligram per liter; $\mathrm{N}$, nitrogen; $\mathrm{NO}_{3}+\mathrm{NO}_{2}$, nitrate plus nitrite]

\begin{tabular}{|c|c|c|c|c|c|c|c|}
\hline Year & $\begin{array}{c}\text { Specific } \\
\text { conductance } \\
(\mu S / \mathrm{cm})\end{array}$ & $\begin{array}{l}\text { Potassium } \\
\text { (mg/L) }\end{array}$ & $\begin{array}{l}\text { Sodium } \\
\text { (mg/L) }\end{array}$ & $\begin{array}{l}\text { Calcium } \\
\text { (mg/L) }\end{array}$ & $\begin{array}{l}\text { Chloride } \\
\text { (mg/L) }\end{array}$ & $\begin{array}{l}\text { Magnesium, } \\
\text { (mg/L) }\end{array}$ & $\begin{array}{c}\text { Alkalinity } \\
\left(\mathrm{mg} / \mathrm{L} \mathrm{CaCO}_{3}\right)\end{array}$ \\
\hline 1979 & 646.8 & 1.4 & 7.1 & 73.0 & 5.2 & 36.0 & 300.0 \\
\hline 2010 & 760.0 & 1.7 & 12.4 & 86.0 & 8.6 & 44.3 & 345.0 \\
\hline Year & $\begin{array}{c}\mathrm{NO}_{3}+\mathrm{NO}_{2} \\
(\mathrm{mg} / \mathrm{L} \text { as N })\end{array}$ & $\begin{array}{c}\text { Ammonia } \\
\text { (mg/L as } N \text { ) }\end{array}$ & $\begin{array}{l}\text { Sulfate } \\
\text { (mg/L) }\end{array}$ & $\begin{array}{l}\text { Dissolved } \\
\text { solids dry at } \\
180^{\circ} \mathrm{C} \\
\text { (mg/L) }\end{array}$ & $\begin{array}{c}\text { pH } \\
\text { (standard } \\
\text { units) }\end{array}$ & $\begin{array}{c}\text { Water } \\
\text { temperature } \\
\left({ }^{\circ} \mathrm{C}\right)\end{array}$ & \\
\hline 1979 & 0.0 & 0.2 & 26.0 & 384.0 & 7.6 & 11.0 & \\
\hline 2010 & 0.0 & 0.5 & 42.0 & 462.5 & 7.4 & 11.9 & \\
\hline
\end{tabular}




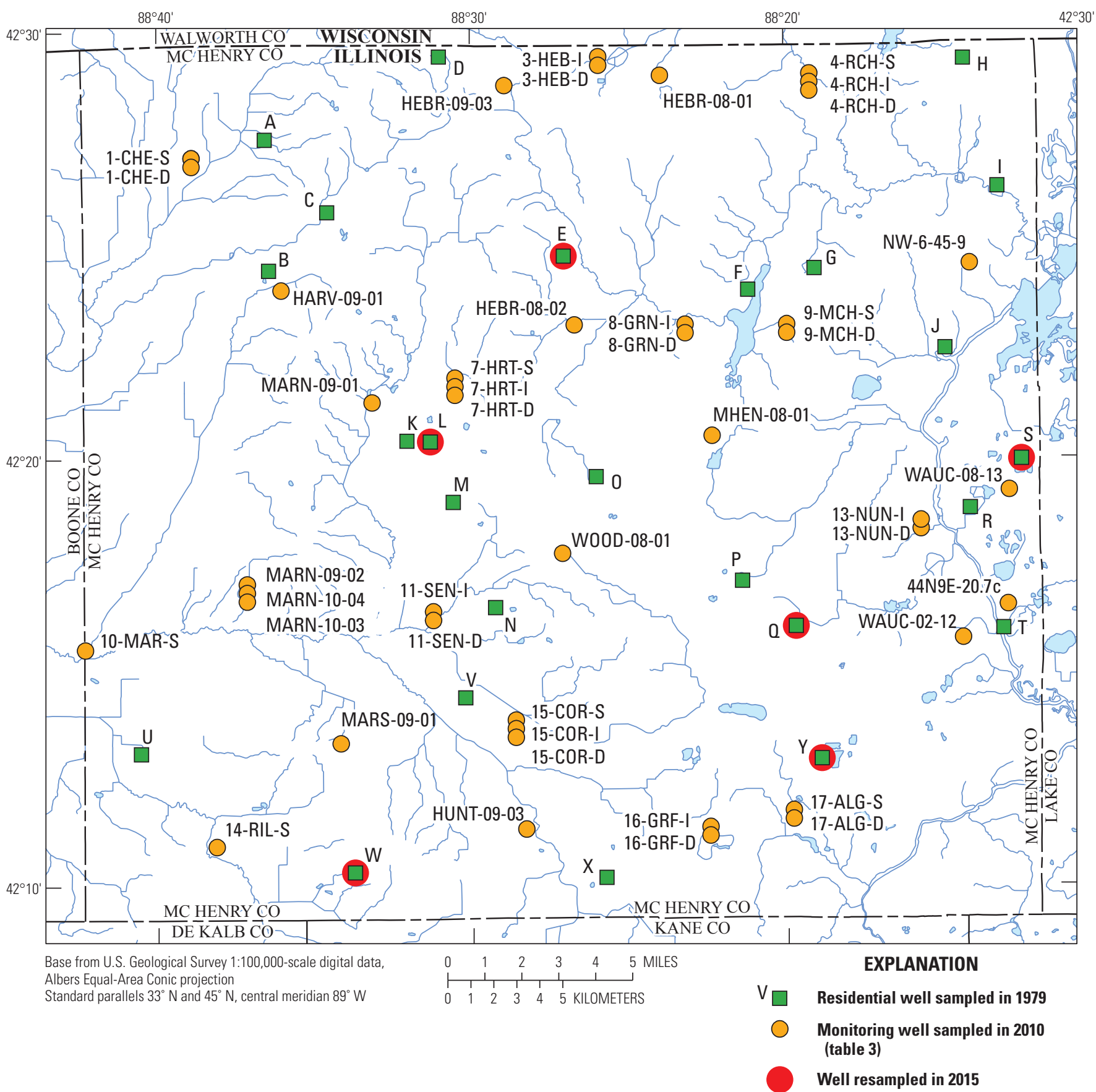

Figure 37. Residential wells sampled in the McHenry County groundwater monitoring network, Illinois, 1979 and 2010 . Wells sampled in 1979 are from Nicholas and Krohelski (1984). Monitoring wells sampled in 2010 are shown in table 3. 
Median chloride concentration for the 25 wells sampled in 1979 was $5.2 \mathrm{mg} / \mathrm{L}$, with a maximum concentration of $60 \mathrm{mg} / \mathrm{L}$, reported for a well with a depth of $49 \mathrm{ft}$. Chloride concentrations for the 2010 dataset had a median concentration of $8.6 \mathrm{mg} / \mathrm{L}$, with the highest concentrations of $149 \mathrm{mg} / \mathrm{L}$, detected at a well with a depth of $58.7 \mathrm{ft}$. Chloride concentrations are compared with well depths (greater than $50 \mathrm{ft}$ ) in figure $38 \mathrm{for}$ the 1979 and 2010 datasets. Higher chloride concentrations were detected in shallow (less than $150 \mathrm{ft}$ deep) wells in the 1979 dataset. Allother constituents were not statistically different. A previous study by Lindsey and Rupert (2012) estimated that $22 \mathrm{mg} / \mathrm{L}$ of chloride is added to the groundwater per year in the U.S. That same study also showed that TDS increased by more than 50 percent from 2000 to 2010 in water-quality samples from four of six NAWQA wells in McHenry County (Lindsey and Rupert, 2012).

During 2015, six (6) of the original 25 residential supply wells used in the 1979 study were identified and resampled for chloride to identify any changes in concentrations over time (fig. 37, table 28). The shallow wells ( $\mathrm{S}$ and $\mathrm{Y}$ ) and one deeper well (L) are located near major roadways where chloride concentrations in groundwater more than doubled by 2015 . Concentrations have increased between 108 and 521 percent in three of six sampled wells, and likely is the result of road-salt applications. Two deep wells ( $\mathrm{Q}$ and $\mathrm{W}$ ) and the remaining shallow well (E), located more than $0.5 \mathrm{mi}$ away from any major road, had chloride concentrations that were relatively unchanged or that decreased from 1979 to 2015.

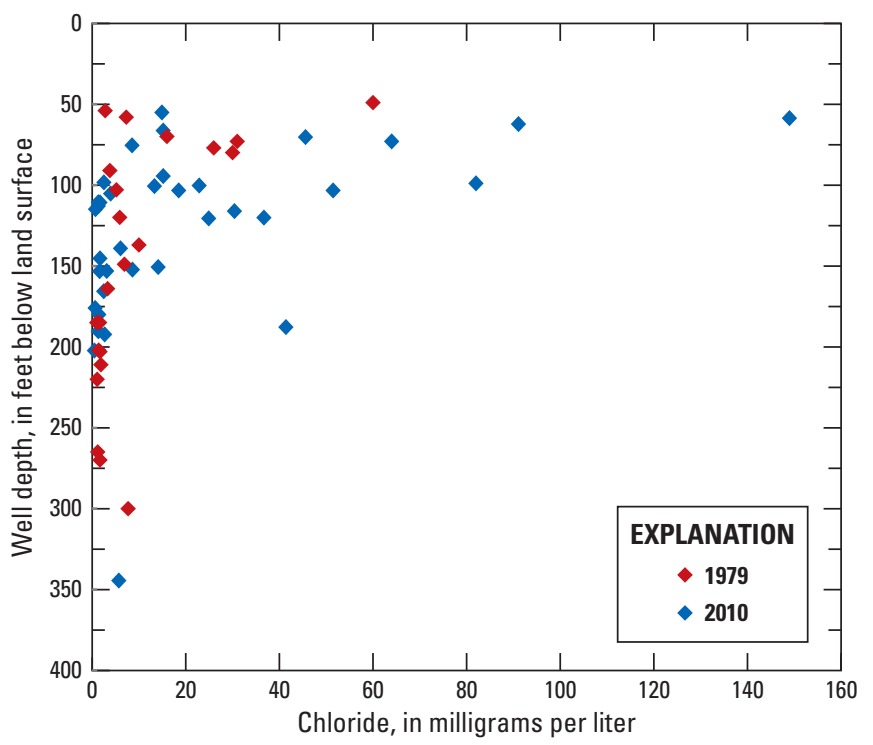

Figure 38. Chloride concentrations and well depths of the 1979 residential wells and the 2010 monitoring wells (well depths greater than 50 feet) in the McHenry County groundwater monitoring network, Illinois. Wells sampled in 1979 are from Nicholas and Krohelski (1984).
Table 28. Chloride concentrations in water-quality samples collected from resampled and sampled residential wells, McHenry County, Illinois, 1979 and 2015, respectively.

[Residential well: Locations of wells are shown in figure 36. Chloride: Wells sampled in 1979 are from Nicholas and Krohelski (1984). Abbreviations: ft, foot; mg/L, millgram per liter; USGS, U.S. Geological Survey]

\begin{tabular}{ccccc}
\hline \multirow{2}{*}{$\begin{array}{c}\text { Residential } \\
\text { well }\end{array}$} & \multirow{2}{*}{$\begin{array}{c}\text { USGS } \\
\text { well No. }\end{array}$} & \multirow{2}{*}{$\begin{array}{c}\text { Well depth } \\
\text { (ft) }\end{array}$} & \multicolumn{2}{c}{ Chloride (mg/L) } \\
\cline { 5 - 5 } & S & & $\mathbf{1 9 7 9}$ & $\mathbf{2 0 1 5}$ \\
\hline S & 421958088122901 & 49 & 60 & 162 \\
Y & 421258088185401 & 50 & 51 & 106 \\
E & 422450088270201 & 77 & 26 & 10.7 \\
L & 422025088311801 & 137 & 10 & 62.1 \\
Q & 421604088194201 & 203 & 1.7 & 1.82 \\
W & 421020088334501 & 300 & 2 & 2.34 \\
\hline
\end{tabular}

\section{Summary and Conclusions}

The rapid growth of population in McHenry County, Illinois, has led to concerns about the quantity and quality of their primary drinking water source: the shallow sand and gravel aquifer. To address these concerns, State and Federal agencies worked in collaboration on behalf of McHenry County to install the McHenry County groundwater monitoring network (MCGMN), which is a network of 44 monitoring wells that are equipped with real-time pressure transducers that record water levels at 15-minute intervals and are relayed hourly through satellite transmission to the U.S. Geological Survey National Water Information System Web interface. Some of the wells are nested with as many as three different depths at 11 locations. Groundwater-level data have been collected from the MCGMN since 2009. The continuous water-level data were used in this report to determine the local and regional hydrogeologic setting, which includes the degree of aquifer confinement (aquifer type) and interconnection, areas of recharge and discharge (calculated from vertical gradients), and recharge quantities (estimated from water-table fluctuation [WT fluctuation]) for the period of study (2009-14), as well as, pumping influences, and trends in response to annual variations. Water-quality data collected in 2010 from the MCGMN and the U.S. Geological Survey National Water-Quality Assessment (NAWQA) program wells provided an assessment of the drinking and ambient water quality of the sand and gravel aquifers. The water levels and water-quality data serve as a baseline for monitoring changes in the sand and gravel aquifers as the population continues to increase in McHenry County.

The geology and the potentiometric surface of a water level is not always enough to determine the degree of aquifer confinement, particularly for a glacial aquifer. The continuous water level data identified several areas that are not only unconfined, but also interconnected to deeper aquifer units 
within the sand and gravel aquifers. The vertical gradients further clarify which aquifer units are connected and show the locations of either recharge to (that is, downwards flow) or discharge from (upwards flow) lower intervals of the aquifer. Monitoring wells in areas of recharge (16-GRF-I/D, 7-HRT-S/I/D, 15-COR-S 11-SEN-I/D) showed downward vertical flow gradients. These predominately downward vertical flow gradients also corresponded with rapid responses to precipitation, and in some cases, oxic or mixed redox conditions. The aquifer type and areas with interconnected aquifers can be used by water managers as a preliminary assessment tool for identifying areas with greater amounts of water availability, as well as identifying areas with lower vulnerability to surface pollutants.

Pumping influences were observed in 43 percent of the wells, with most occurring along the eastern one-half of the county in the more populated areas. Annual variations in water levels related to the 2012 drought conditions indicated that numerous wells with drawdowns between 7 and 10 feet (ft), and as much as $30 \mathrm{ft}$, generally also were influenced by pumping or limited recharge. Periods of drought and subsequent increases in withdrawals intensify the drawdown at many locations. Prolonged droughts could decrease base flow to surface water.

The recharge values and vertical gradients indicate that the geology in the eastern one-half of the county is primarily sand and gravel, with limited thicknesses of clays or lower permeable material near the surface. Annual recharge amounts calculated using the WT fluctuation method ranged from 1.17 to 4.60 inches per year at various locations across the county. The eastern half of the county generally had higher average amounts of recharge per year than the western part, which is in general agreement with previous aquifer sensitivity evaluations. At nested monitoring wells with downward vertical gradients, some NAWQA wells and some shallow MCGMN wells in urban areas have traces of pesticides and volatile organic compounds (VOCs), along with elevated chloride, major ions, and boron concentrations, indicating that the aquifer is vulnerable to surface contaminants along the eastern half of the county.

A visual assessment of temporal trends in the groundwater levels from 2009 to 2014 indicated that water levels in most wells have been stable, with a few areas that have a delayed response to recharge. A few wells located in the eastern half of the county had declines in water levels that have remained persistent since the 2012 severe drought. Three of the five wells with declining trends have pumping influences, which may be contributing to the delayed recovery since the drought. Long-term water-level data are needed to determine if the declining trends at wells are related to withdrawals exceeding recharge. Monitoring well 17-ALG-D is the only well with a rising trend, and it is screened in the shallow bedrock aquifer. Rising water-level trends may be related to changes in withdrawal rates at a nearby deep supply well.
Water-quality samples were collected from 46 monitoring wells in 2010. U.S. Environmental Protection Agency (EPA) health-based drinking water-quality standards (either MCL or DWA) were exceeded for four constituents: arsenic, sodium, manganese, and nitrates. Elevated arsenic concentrations generally occurred in deeper wells (wells greater than 66 feet below land surface) and seemed to be naturally occurring. Exceedances occurred primarily in wells in the western half of the county, and two locations with exceedances occurred in the eastern half (4-RCH-I/D and 17-ALG-D). Arsenic concentrations greater than the $10 \mu \mathrm{g} / \mathrm{L}$ EPA MCL tended to occur in anoxic to suboxic redox conditions. Sodium concentrations exceeded the EPA DWA in wells that also had elevated chloride concentrations and is likely attributed to road salt applications. Exceedances of EPA DWA occurred for manganese in one sample (10-MAR-S), and manganese concentrations were generally elevated in shallower wells, possibly related to the natural presence of manganese in the overlying soil. Only one of the 46 wells sampled, 14-RIL-S, had a nitrate detection at the EPA MCL of $10 \mathrm{mg} / \mathrm{L}$; all other locations had nitrate concentrations less than $4 \mathrm{mg} / \mathrm{L}$. Nitrate concentrations greater than $2 \mathrm{mg} / \mathrm{L}$ indicate anthropogenic sources. Many of the VOCs and pesticides often were detected in water-quality samples collected from the same wells, mostly the NAWQA wells and 9-MCH-S. These wells primarily are located in the eastern half of the county, where there is a greater urban density and the aquifer is more sensitive to recharge.

Exceedances in EPA nonenforceable aesthetically-based drinking water standards (SMCL) occurred for total dissolved solids, chlorides, iron, and manganese. The monitoring wells with the highest chloride concentrations (greater than $195 \mathrm{mg} / \mathrm{L}$ ) are in areas receiving runoff based on proximity to roads (4-RCH-S, 9-MCH-S, 14-RIL-S) and in urbanized areas (NAWQA wells). Assessment of chloride sources using chloride-bromide ratio analysis has shown evidence of multiple possible sources and mixtures of sources such as road salt, sewage, and water-softener discharge.

Differences in water-quality data from 1979 to 2010 were evaluated using the Wilcoxon rank sum statistical test. The sampled wells from a previous U.S. Geological Survey study in 1979 generally were deeper (greater than $50 \mathrm{ft}$ below land surface) than those in the 2010 study presented here. Water-quality data collected in 2010 from monitoring wells less than $50 \mathrm{ft}$ in depth were not included in the statistical comparisons. Specific conductance and total dissolved solids were the only constituents that had statistically significant (p-value less than 0.05) increases. The increase in specific conductance and total dissolved solids is potentially because of the addition of road salts based on the results of the $\mathrm{Cl}-\mathrm{Br}$ plots. Chloride concentrations did not have a statistically significant (albeit close at a p-value equal to 0.054 ) increase in wells greater than $50 \mathrm{ft}$ depth. However, the resampled residential supply wells from the 1979 study, in 2015, showed increases in chloride concentration by as much as 520 percent. 
Chloride concentrations increased substantially at shallow and deep wells near major roads and in urban areas.

The detection of elevated chloride in the shallowest aquifer unit (less than $50 \mathrm{ft}$ below land surface) in urban areas and near roads presents an ecological risk because this unit is the primary part of the groundwater that enters streams as base flow. The chloride concentrations in groundwater at many locations near roadsides and in urbanized areas are greater than the chronic toxicity aquatic level criterion established by the EPA. When the shallow groundwater discharges to nearby streams and wetlands, the elevated chloride concentrations can potentially reduce aquatic diversity by artificially selecting for salt-tolerant species. Specific conductance was monitored continuously at five monitoring wells to determine seasonal trends in chloride and to assess the factors that influence the concentrations, fate and transport. These data were used to develop equations for estimating the chloride concentration over time at each location, and the results were considered in regards to potable drinking water and aquatic health. The range in chloride concentrations throughout the year at three out of four continuously monitoring specific conductance wells are near or greater than the EPA chronic aquatic toxicity criterion $(230 \mathrm{mg} / \mathrm{L})$ and the EPA secondary maximum contaminant level $(250 \mathrm{mg} / \mathrm{L})$. The continuous water-quality data show that chloride concentrations vary greatly in response to weather trends and geology. The continuous data indicated that aquifer thickness and hydraulic conductivity have the greatest controls on the concentrations of chloride through time. High hydraulic conductivities and thick saturated aquifers have episodic increases in chloride concentrations. Conversely, low hydraulic conductivities and thin saturated aquifers allow the chloride from yearly road salt applications to be stored and to concentrate. The effects that hydraulic conductivity and aquifer thickness have on constituent concentrations could be used to improve the timing for obtaining discrete water-quality samples, and could help explain the variability in discrete chloride concentration data, such as at well 44N9E-20.7c. Additional long-term continuous data in the shallow groundwater and nearby surface water may help to assess chloride loads entering the streams during spring snowmelt and runoff. Additionally, a groundwater flow model may help to determine the threshold and maximum depth that the chlorides may reach. Road-salt application quantities and locations are needed for a more thorough assessment of the causes of variability and would help assess whether the current (2016) established best management practices aimed at reducing the amount of chloride entering the groundwater system are adequate.

\section{Acknowledgments}

The author would like to thank the six homeowners who allowed U.S. Geological Survey personnel to collect water-quality samples from their wells. Additionally, the author would like to thank the valuable assistance provided by Joanna Colletti and Dennis Sandquist at McHenry County Planning and Development. John Mullaney of the U.S. Geological Survey is also thanked for providing assistance with the chloride-bromide analysis.

\section{References Cited}

AECOM, 2009, Observation well network installation McHenry County, Illinois: Chicago, Ill., Report prepared by AECOM for U.S. Army Corps of Engineers [variously paged].

Agency for Toxic Substances and Disease Registry, 2011, Hydrogen sulfide-ToxFAQs ${ }^{\mathrm{TM}}$ : Agency for Toxic Substances and Disease Registry, accessed August 28, 2015, at http://www.atsdr.cdc.gov/toxfaqs/tfacts114.pdf.

Alley, W.M., Reilly, T.E., and Franke, O.L., 1999, Sustainability of ground-water resources: U.S. Geological Survey Circular 1186, 79 p., accessed August 28, 2015, at http://pubs.usgs.gov/circ/circ1186/index.html.

Anderson, C.W., and Rounds, S.A., 2010, Use of continuous monitors and autosamplers to predict unmeasured water-quality constituents in tributaries of the Tualatin River, Oregon: U.S. Geological Survey Scientific Investigations Report 2010-5008, 76 p.

Angel, Jim, 2009, Climate events of 2009 in Illinois: Champaign, State Climatologist Office for Illinois, State Water Survey website, accessed August 28, 2015, http:// www.isws.illinois.edu/atmos/statecli/events2009.htm.

Angel, Jim, 2012, Year without winter in Chicago-Illinois State Climatologist: Illinois State Water Survey website, accessed February 13, 2012, at https://climateillinois. wordpress.com/2012/02/13/year-without-winter-in-chicago/.

Ayotte, J.D., Gronberg, J.M., and Apodaca, L.E., 2011, Trace elements and radon in groundwater across the United States: U.S. Geological Survey Scientific Investigations Report 2011-5059, $115 \mathrm{p}$. 
Barlow, P.M., Cunningham, W.L., Zhai, Tong, and Gray, Mark, 2014, U.S. Geological Survey groundwater toolbox, a graphical and mapping interface for analysis of hydrologic data (ver. 1.0) — User guide for estimation of base flow, runoff, and groundwater recharge from streamflow data: U.S. Geological Survey Techniques and Methods, book 3, chap. B10, 27 p., accessed May 2015 at http://pubs.usgs. gov/tm/03/b10/.

Barlow, P.M., and Moench, A.F., 1999, WTAQ_A computer program for calculating drawdowns and estimating hydraulic properties for confined and water-table aquifers: U.S. Geological Survey Water-Resources Investigations Report 99-4225, 74 p., accessed August 2015 at http://pubs. usgs.gov/wri/wri99-4225/.

Baxter and Woodman, Inc., 2006, Report 3-Countywide groundwater quantity and quality protection plan, final: Crystal Lake, Illinois, Baxter and Woodman, Inc., accessed August 2015 at https://www.co.mchenry.il.us/countygovernment/departments-j-z/planning-development/ divisions/water-resources/groundwater-management-plan.

Brenton, R.W., and Arnett, T.L., 1993, Methods of analysis by the U.S. Geological Survey National Water Quality Laboratory - Determination of dissolved organic carbon by uv-promoted persulfate oxidation and infrared spectrometry: U.S. Geological Survey Open-File Report 92-480, 12 p., http://pubs.er.usgs.gov/publication/ofr92480/.

Bohling, G.C., Jin, W., and Butler, J.J., 2014, KGS barometric response function software: Lawrence, Kansas Geological Survey, accessed May 2016 at http://www.kgs.ku.edu/ HighPlains/OHP/index_program/brf.html.

Brown, C.J., Mullaney, J.R., Morrison, J., and Mondazzi, R., 2011, Preliminary assessment of chloride concentrations, loads, and yields in selected watersheds along the Interstate 95 corridor, southeastern Connecticut, 2008-09: U.S. Geological Survey Open-File Report 2011-1018, 41 p., accessed October 2014 at http://pubs.usgs.gov/ of/2011/1018/.

Brown, K.J., 2002, McHenry County, Illinois, watersheds: Champaign, Illinois State Water Survey, accessed November 9, 2015, accessed August 2015 at https://www. co.mchenry.il.us/home/showdocument?id=8762.

Burkart, D.M.R., and Stoner, J.D., 2008, Nitrogen in groundwater associated with agricultural systems, chap. 7 of Hatfield, J.L, and Follett, R.F., eds., Nitrogen in the environment-Sources, problems, and management: Boston, Academic Press/Elsevier, U.S. Department of Agriculture-Agricultural Research Service / University of Nebraska-Lincoln Faculty Paper 259, accessed August 2015 at http://digitalcommons.unl.edu/usdaarsfacpub/259.
Butler, J.J., Jin, W., Mohammed, G.A., and Reboulet, E.C., 2011, New insights from well responses to fluctuations in barometric pressure: Ground Water, v. 49, no. 4, p. 525-533.

Capel, P.D., Spexet, A.H., and Larson, S.J., 1999, Occurrence and behavior of the herbicide prometon in the hydrologic system: Environmental Science and Technology, v. 33, p. 674-680.

Chapelle, F.H., Widdowson, M.A., Brauner, J.S., Mendez, E., III, and Casey, C.C., 2003, Methodology for estimating times of remediation associated with monitored natural attenuation: U.S. Geological Survey Water-Resources Investigations Report 2003-4057, 52 p.

Chicago Metropolitan Agency for Planning, 2012, Population forecast - 2040 forecast of population, households, and employment: Chicago Metropolitan Agency for Planning website, accessed May 2015, at http://www.cmap.illinois. gov/data/demographics/population-forecast.

Chicago Metropolitan Agency for Planning, 2013, Appendix A-Primary impacts of climate change in the Chicago region: Chicago Metropolitan Agency for Planning, 33 p.

Childress, C.J.O., Forman, W.T., Connor, B.F., and Maloney, T.J., 1999, New reporting procedures based on long-term method detection levels and some considerations for interpretations of water-quality data provided by the U.S. Geological Survey National Water Quality Laboratory: U.S. Geological Survey Open-File Report 99-193, 19 p., accessed July, 7, 2016, at http://water.usgs.gov/owq/ OFR_99-193/ofr99_193.pdf.

Christensen, V.G., Jian, X., and Ziegler, A.C., 2000, Regression analysis and real-time water-quality monitoring to estimate constituent concentrations, loads, and yields in the Little Arkansas River, south-central Kansas: U.S. Geological Survey Water-Resources Investigations Report 2000-4126, 36 p., accessed August 2015, at https:// pubs.er.usgs.gov/publication/wri004126.

Connor, B.F., Rose, D.L., Noriega, M.C., Murtaugh, L.K., and Abney, S.R., 1998, Methods of analysis by the U.S. Geological Survey National Water Quality Laboratory-Determination of 86 volatile organic compounds in water by gas chromatography, including detections less than reporting limits: U.S. Geological Survey Open-File Report 97-829, 78 p.

Csallany, S., and Walton, W.C., 1963, Yields of shallow dolomite wells in northern Illinois: Champaign, Illinois State Water Survey Report of Investigation 46, 43 p.

Cunningham, W.L., and Schalk, C.W., comps., 2011, Groundwater technical procedures of the U.S. Geological Survey: U.S. Geological Survey Techniques and Methods 1-A1, 151 p. [Available at http://pubs.usgs.gov/ $\mathrm{tm} / 1 \mathrm{a} 1 /$. 
Curry, B.B., Berg, R.C., and Vaiden, R.C., 1997, Geologic mapping for environmental planning, McHenry County, Illinois: Illinois State Geological Survey Circular 559, 79 p.

Daley, M.L., Potter, J.D., and McDowell, W.H., 2009, Salinization of urbanizing New Hampshire streams and groundwater-Effects of road salt and hydrologic variability: Journal of North American Benthological Society, v. 28, no. 4, p. 929-940.

Davis, S.N., Whittemore, D.O., and Fabryka-Martin, J., 1998, Uses of chloride/bromide ratios in studies of potable water: Ground Water, v. 36, no. 2, p. 338-350.

Delin, G.N., Healy, R.W., Lorenz, D.L., and Nimmo, J.R., 2007, Comparison of local- to regional-scale estimates of groundwater recharge in Minnesota, USA: Journal of Hydrology, v. 334, p. 231-249.

Dinicola, R.S., 2006, Evidence for chloroethene biodegradation in groundwater at former building 957 storage area, area 2, operable unit 2, Naval Undersea Warfare Center, Division Keyport, Washington: U.S. Geological Survey Scientific Investigations Report 2006$5030,12 \mathrm{p}$.

Edwards, P.J., Williard, K.W.J., and Schoonover, J.E., 2015, Fundamentals of watershed hydrology: Journal of Contemporary Water Research and Education, no. 154, p. 3-20, accessed August 2015 at http://onlinelibrary.wiley. com/doi/10.1111/j.1936-704X.2015.03185.x/epdf.

Fetter, C.W., 1988, Applied hydrogeology (2d ed.), chap. 5.5.3: Columbus, Ohio, Merrill Publishing Company, p 125.

Fetter, C.W., 1998, Contaminant hydrogeology (2d ed.), chap. 6.10: Prentice Hall, p. 311.

Fishman, M.J., ed., 1993, Methods of analysis by the U.S. Geological Survey National Water Quality LaboratoryDetermination of inorganic and organic constituents in water and fluvial sediments: U.S. Geological Survey Open-File Report 93-125, 217 p., http://pubs.er.usgs.gov/ publication/ofr93125/.

Fishman, M.J., and Friedman, L.C., 1989, Methods for determination of inorganic substances in water and fluvial sediments: U.S. Geological Survey Techniques of WaterResources Investigations, book 5, chap. A1, 545 p., http:// pubs.usgs.gov/twri/twri5-a1/.

Freeze, R.A., and Cherry, J.A., 1979, Groundwater: Englewood Cliffs, New Jersey, Prentice-Hall, Inc., 604 p.

Freeman, L.A., Carpenter, M.C., Rosenberry, D.O., Rousseau, J.P., Unger, R., and McLean, J.S., 2004, Use of submersible pressure transducers in water-resources investigations: U.S. Geological Survey Techniques of Water-Resources Investigations, book 8, chap. A, $65 \mathrm{p}$.
Furlong, E.T., Anderson, B.D., Werner, S.L., Soliven, P.P., Coffey, L. J., and Burkhardt, M.R., 2001, Methods of analysis by the U.S. Geological Survey National Water Quality Laboratory-Determination of pesticides in water by graphitized carbon-based solid-phase extraction and high-performance liquid chromatography/mass spectrometry: U.S. Geological Survey Water-Resources Investigations Report 01-4134, $73 \mathrm{p}$.

Fujii, R., Ranalli, A.J., Aiken, G.R., and Bergamaschi, B.A., 1998, Dissolved organic carbon concentrations and compositions, and trihalomethane formation potentials in water from agricultural peat soils, Sacramento-San Joaquin Delta, California-Implications for drinking-water quality: U.S. Geological Survey Water-Resources Investigations Report 98-4147, 81 p., accessed July 2016 at http://pubs. usgs.gov/wri/wri984147/wrir984147.pdf.

Garbarino, J.R., Kanagy, L.K., and Cree, M.E., 2006, Determination of elements in natural-water, biota, sediment, and soil samples using collision/reaction cell inductively coupled plasma-mass spectrometry: U.S. Geological Survey Techniques and Methods, book 5, chapter 1, section B, 88 p., http://pubs.usgs.gov/tm/2006/tm5b1/.

Gilliom, R.J., and others, 2006, The Quality of our Nation's waters-Pesticides in the Nation's streams and ground water, 1992-2001: U.S. Geological Survey Circular 1291, $172 \mathrm{p}$.

Goodman, M., Mandel, J.S., DeSesso, J.M., Scialli, A.R., 2014, Atrazine and pregnancy outcomes-A systematic review of epidemiologic evidence: Birth Defects Research (Part B), Wiley Periodicals, Inc. v. 101, p. 215-236, accessed August 14, 2017, at https://www.ncbi.nlm.nih.gov/ pmc/articles/PMC4265844/pdf/bdrb0101-0215.pdf.

Google, 2015, Hello, Earth-Google Earth ${ }^{\mathrm{TM}}$ Pro: Google website, accessed March 2016, at https://www.google.com/ work/earthmaps/earthpro.html.

Groschen, G.E., Arnold, T.L., Morrow, W.S., and Warner, K.L., 2009, Occurrence and distribution of iron, manganese, and selected trace elements in ground water in the glacial aquifer system of the northern United States: U.S. Geological Survey Scientific Investigations Report 20095006, 89 p., accessed June 2016 at https://pubs.usgs.gov/ sir/2009/5006/pdf/sir2009-5006.pdf.

Groundwater Resources Management Plan Task Force, 2006, County of McHenry, Illinois - Groundwater Resources Management Plan-Final, November 2006, executive summary: Prepared by Baxter and Woodman, Incorporated; Environmental Planning and Economics, Incorporated; Ayres Associates; Planning and Management Consultants, Incorporated; and Adrian Visocky; accessed June 2014 at https://www.co.mchenry.il.us/county-government/ departments-j-z/planning-development/divisions/waterresources/groundwater-management-plan. 
Hackett, J.E., and McComas, M.R., 1969, Geology for planning in McHenry County, Illinois: Illinois State Geological Survey Circular 438, 29 p.

Hayes, T.B., Khoury, V., Narayan, A., Nazir, M., Park, A., Brown, T., Adame, L., Chan, E., Buchholz, D., Stueve, T., and Gallipeau, S., 2010, Atrazine induces complete feminization and chemical castration in male African clawed frogs (Xenopus laevis): Proceedings of the National Academy of Sciences of the United States of America (PNAS), v. 107, no. 10, p. 4612-4617, accessed August 14, 2017, at http://www.pnas.org/content/107/10/4612.full.

Healy, R.W., and Cook, P.G., 2002, Using groundwater levels to estimate recharge: Hydrogeology Journal, v. 10, p. 91-109.

Helsel, D.R., 2005, Nondetects and data analysis-Statistics for censored environmental data: Hoboken, New Jersey, John Wiley \& Sons, 250 p.

Helsel, D.R., and Hirsch, R.M., 2002, Statistical methods in water resources: U.S. Geological Survey Techniques of Water-Resources Investigations, book 4, chap. A3, 522 p., accessed May 2015 at http://pubs.usgs.gov/twri/twri4a3/ pdf/twri4a3-new.pdf.

Hem, J.D., 1989, Study and interpretation of the chemical characteristics of natural water (3d ed.): U.S. Geological Survey Water-Supply Paper 2254, 263 p.

Homer, C.G., Dewitz, J.A., Yang, L., Jin, S., Danielson, P., Xian, G., Coulston, J., Herold, N.D., Wickham, J.D., and Megown, K., 2015, Completion of the 2011 National Land Cover Database for the conterminous United StatesRepresenting a decade of land cover change information: Photogrammetric Engineering and Remote Sensing, v. 81, no. 5, p. 345-354, database accessed August 2015 at http:// www.mrlc.gov/nlcd2011.php.

Illinois Department of Natural Resources and Illinois Environmental Protection Agency, 2013, The drought of 2012-A report of the Governor's Drought Response Task Force: State of Illinois Department of Natural Resources, 17 p. plus apps., accessed June 2014 at http:// www.isws.illinois.edu/hilites/drought/archive/2012/docs/ TheDroughtOf2012.pdf.

Illinois State Geological Survey, 2016, 3-D geologic modeling data: Illinois State Geological Survey website, accessed May 2015 at http://isgs.illinois.edu/content/3-d-geologicmodeling-data.

Illinois State Water Survey, 2002, Arsenic in Illinois groundwater: Champaign, Illinois State Water Survey Web page, accessed June 20, 2015, at http://www.isws.illinois. edu/gws/archive/arsenic/ilsources.asp.
Illinois State Water Survey, 2016, Illinois Climate NetworkMonthly and daily data-Water and Atmospheric Resources Monitoring Program (WARM): Champaign, Illinois State Water Survey Web page, accessed April 2015 at http:// dx.doi.org/10.13012/J8MW2F2Q.

Ivahnenko, T., and Zogorski, J.S., 2006, Sources and occurrence of chloroform and other trihalomethanes in drinking-water supply wells in the United States, 19862001: U.S. Geological Survey Scientific Investigations Report 2006-5015, 13 p. accessed June 2016 at http://pubs. usgs.gov/sir/2006/5015/sir2006-5015.pdf.

Johnson, A.I., 1967, Specific yield-Compilation of specific yields for various materials: U.S. Geological Survey Water-Supply Paper 1662-D, 80 p.

Jurgens, B.C., Fram, M.S., Belitz, K., Burow, K.R., and Landon, M., 2009, Effects of groundwater development on uranium-Central Valley, California, USA: Ground Water, 16 p., accessed June 2016 at http://oh.water.usgs.gov/tanc/ pubs/Jurgens\&Others_2009.pdf.

Kasenow, M., 2010, Aquifer test data-Analysis and evaluation (8th printing): Highlands Ranch, Colorado, Water Resources Publications, $344 \mathrm{p}$.

Katz, B.G., Eberts, S.M., and Kauffman, L.J., 2011, Using $\mathrm{Cl} / \mathrm{Br}$ ratios and other indicators to assess potential impacts on groundwater quality form septic systems - A review and examples from principal aquifers in the United States: Journal of Hydrology, v. 397, p. 151-166, accessed July 13, 2015, at http://oh.water.usgs.gov/tanc/pubs/Katz\%20et\%20 al\%20J\%20Hydrol\%20septic\%20systems.pdf.

Kelly, W.R., Panno, S.V., and Hackley, K.C., 2009, Impacts of road salt on water resources in the Chicago regionPaper 5, in Conference proceedings, Universities Council on Water Resources annual conference, Chicago, Illinois, July 7-9, 2009: Carbondale, Southern Illinois University, 8 p., accessed January 2015 at http://opensiuc.lib.siu.edu/ ucowrconfs_2009/5.

Kerr, P., Tassier-Surine, S., Streeter, M., and Gannon, J.M., 2015, Geologic evaluation of the buried sand and gravel aquifers in western Iowa: Iowa Geological Survey, Water Resources Investigation Report 14.

Kolata, D.R. and Graese, A.E., 1983, Lithostratigraphy and depositional environments of the Maquoketa Group (Ordovician) in Northern Illinois: Illinois State Geological Survey Circular 528, p. 49.

Larson, D.R., and Herzog, B.L., 2010, Aquifers, chap. 18 of Geology of Illinois: Champaign, Illinois State Geological Survey, p. 325-336. 
Lawrence, S.J., 2006, Description, properties, and degradation of selected volatile organic compounds detected in ground water-A review of selected literature: U.S. Geological Survey Open-File Report 2006-1338, p. 20-24, accessed October 2, 2017, at https://pubs.usgs.gov/of/2006/1338/pdf/ ofr2006-1338.pdf.

Lindsey, B.D., and Rupert, M.G., 2012, Methods for evaluating temporal groundwater quality data and results of decadal-scale changes in chloride, dissolved solids, and nitrate concentrations in groundwater in the United States, 1988-2010: U.S. Geological Survey Scientific Investigations Report 2012-5049, 46 p.

Loper, C.A., Breen, K.J., Zimmerman, T.M., and Clune, J.W., 2009 , Pesticides in ground water in selected agricultural land-use areas and hydrogeologic settings in Pennsylvania, 2003-07: U.S. Geological Survey Scientific Investigations Report 2009-5139, $121 \mathrm{p}$.

Lyday, P.A., 2003, Boron, in U.S. Geological Survey, Minerals yearbook-Volume I, Metals and minerals, p. 13.1-13.10, accessed July 2016 at http://minerals.usgs.gov/minerals/ pubs/commodity/boron/boronmyb03.pdf.

Madison, R.J., and Brunett, J.O., 1985, Overview of the occurrence of nitrate in ground water of the United States, in National Water Summary 1984-Hydrologic events, selected water-quality trends, and ground-water resources: U.S. Geological Survey Water-Supply Paper 2275, p. $93-105$.

Mahler, B.J., Van Metre, P.C., and Callender, E., 2006, Trends in metals in urban and reference lake sediments across the United States, 1970 to 2001: Environmental Toxicology and Chemistry, v. 25, no. 7, p. 1678-1709, accessed July 2016 at http://tx.usgs.gov/coring/pubs/trends\%20metals.pdf.

Mashburn, S.L., Cope, C.C., and Abbott, M.M., 2003, Aquifer characteristics, water availability, and water quality of the Quaternary Aquifer, Osage County, northeastern Oklahoma, 2001-2002: U.S. Geological Survey Water-Resources Investigations Report 03-4235, 41 p., accessed July 2016 at http://pubs.usgs.gov/wri/wri034235/.

McHenry County Planning and Development, 2004, Technical reference manual for McHenry County stormwater management ordinance: Prepared for the McHenry County Stormwater Committee, Woodstock, Illinois, accessed June 2015 at https://www.co.mchenry.il.us/home/ showdocument?id=8770.

McHenry County Planning and Development, 2006, McHenry County groundwater resources management plan, accessed June 2015 at https://www.co.mchenry.il.us/ county-government/departments-j-z/planning-development/ divisions/water-resources/groundwater-management-plan.
McMahon, P.B, and Chapelle, F.H., 2008, Redox processes and water quality of selected principal aquifer systems: Ground Water, v. 46, no. 2, 259 p., accessed July 2016 at http://co.water.usgs.gov/publications/non-usgs/ McMah08Redox.pdf.

Metz, P.A., and Brendle, D.L., 1996, Potential for waterquality degradation of interconnected aquifers in westcentral Florida: U.S. Geological Survey Water-Resources Investigations Report 96-4030, accessed April 23, 2015, at http://fl.water.usgs.gov/PDF_files/wri96_4030_metz.pdf.

Meyer, S.C., 1998, Groundwater studies for environmental planning, McHenry County, Illinois: Illinois State Water Survey Contract Report 630, 141 p., accessed May 2014 at http://www.isws.illinois.edu/docs/pubs/ISWSCR630/.

Meyer, S.C., Lin, Y.F., Abrams, D.A., and Roadcap, G.S., 2013, Groundwater simulation modeling and potentiometric surface mapping, McHenry County, Illinois: Champaign, Illinois State Water Survey Contract Report 2013-06, 242 p.

Midwest Technology Assistance Center, 2009, Groundwater availability at Richmond, Illinois, McHenry County: Midwest Technology Assistance Center, Groundwater Resource Assessment for Small Communities, 12 p., accessed August 2015 at http://mtac.isws.illinois.edu/ mtacdocs/gwres/RichmondMTACReport.pdf.

Morrow, W.S., 2002, Anthropogenic constituents in shallow ground water in the Upper Illinois River Basin: U.S. Geological Survey Water-Resources Investigations Report 02-4293, p. 34.

Mueller, D.K, and Helsel, D.R., 1996, Nutrients in the Nation's waters-Too much of a good thing?: U.S. Geological Survey Circular 1136, 24 p., accessed June 1, 2016, at http://pubs.usgs.gov/circ/circ1136/.

Mullaney, J.R., Lorenz, D.L., and Arntson, A.D., 2009, Chloride in groundwater and surface water in areas underlain by the glacial aquifer system, northern United States: U.S Geological Survey Scientific Investigations Report 2009-5086, 41 p., accessed May 2015 at http://pubs. usgs.gov/sir/2009/5086/pdf/sir2009-5086.pdf.

Nadaska, G., Lesny, J., and Michalik, I., 2010, Environmental aspect of manganese chemistry, HEJ: Trnava, Slovakia, University of Ss Cyril and Methodius, Department of Biotechnology, ENV-100702-A, accessed August 11, 2017 at http://heja.szif.hu/ENV/ENV-100702-A/env100702a.pdf.

National Ground Water Association, 2010, Dissolved mineral sources and significance: National Ground Water Association Web page, accessed November 15, 2015, at http://www.ngwa.org/Fundamentals/studying/Pages/ Dissolved-mineral-sources-and-significance.aspx. 
National Weather Service, 2010, Accumulated Precipitation, NOWData-NOAA online Weather Data, National Oceanic and Atmospheric Administration website, accessed August 2015 at http://w2.weather.gov/climate/xmacis.php?wfo=lot.

National Weather Service, 2014, Rockford weather reports from 2011 to 2014: National Weather Service Forecast Office, National Oceanic and Atmospheric Administration website, accessed August 2015 at http://w2.weather.gov/ climate/index.php?wfo=lot.

National Weather Service, 2015, Seasonal snowfall totals for Rockford from 1905 to present: National Oceanic and Atmospheric Administration website, accessed August 2015 at http://www.weather.gov/lot/Rockford_Seasonal_Snow.

Nicholas, J.R., and Krohelski, J.T., 1984, Water in sand and gravel deposits in McHenry County, Illinois: U.S. Geological Survey Water-Resources Investigations Report 83-4048, 34 p.

Panno, S.V., Hackley, K.C., Hwang, H.H., Greenberg, S., Krapac, I.G., Landsberger, S., and O'Kelly, D.J., 2005, Database for the characterization and identification of the sources of sodium and chloride in natural waters of Illinois: Illinois State Geological Survey Open-File Report 2005-1, $15 \mathrm{p}$.

Panno, S.V., Hackley, K.C., Hwang, H.H., Greenberg, S., Krapac, I.G., Landsberger, S., and O'Kelly, D.J., 2006, Characterization and identification of $\mathrm{Na}-\mathrm{Cl}$ sources in ground water: Ground Water, v. 44, no. 2, p. 176-187.

Rutledge, A.T., 1998, Computer programs for describing the recession of ground-water discharge and for estimating mean ground-water recharge and discharge from streamflow records-Update: U.S. Geological Survey Water-Resources Investigations Report 98-4148, 43 p., accessed April 2015 at http://pubs.usgs.gov/wri/wri984148/.

Rutledge, A.T., 2014, Use of groundwater levels with the PULSE analytical model: Ground Water, v. 52, no. 5, p. 789-797.

Rutledge, A.T., and Daniel, C.C., III, 1994, Testing an automated method to estimate groundwater recharge from stream flow records: Ground Water, v. 32, no. 2, p. 180-189.

Shaver, Robert, and Ripley, David, 1989, On the determination of recharge and evapotranspiration by model calibration in shallow water-table aquifers: Bismarck, North Dakota State Water Commission Hydrology Division, 19 p., accessed May 2015 at http://info.ngwa.org/gwol/pdf/890149622.pdf.

Stiff, B.J., and Hansel, A.K., 2004, Quaternary glaciations in Illinois, in Ehlers, J., and Gibbard, P.L., eds., Quaternary glaciation-Extent and chronology, vol. II: Amsterdam, Elsevier, p. 71-82.
Suter, M., Bergstrom, R.E., Smith, H.F., Emrich, G.H., Walton, W.C., and Larson, T.E., 1959, Preliminary report on the groundwater resources of the Chicago Region, Illinois: Urbana, Illinois State Water Survey and Illinois State Geological Survey Cooperative Groundwater Report 1, 89 p.

Taylor, C.J., and Alley, W.M., 2001, Ground-water-level monitoring and the importance of long-term water-level data: U.S. Geological Survey Circular 1217, 68 p.

Tchobanoglous, G., and Schroeder, E.D., 1985, Chap. 1 of Water quality-Characteristic, modeling, modification: Addison Wesley, 768 p.

Tedd, K.M., Misstear, B.D.R, Coxon, C., Daly, D., and Hunter Williams, N.H., 2012, Hydrogeological insights from groundwater level hydrographs in SE Ireland: Quarterly Journal of Engineering Geology and Hydrogeology, v. 45, p. 19-30, accessed August 20, 2015, at http://jegh. lyellcollection.org.

Thomas, M.J. and Eckberg, M., 2015, The effectiveness of water-treatment systems for arsenic used in 11 homes in Southwestern and Central Ohio, 2013: U.S. Geological Survey Scientific Investigations Report 2015-5156, accessed August 2016 at https://pubs.er.usgs.gov/ publication/sir20155156.

Thomason, J.F., and Keefer, D.A., 2013, 3-D geologic mapping for McHenry County, Illinois: Champaign, Illinois State Geological Survey Contract Report, p. 189.

U.S. Census Bureau, 2010, McHenry County, Illinois: U.S. Census Bureau website, accessed August 2014 at http:// www.census.gov/2010census/data/.

U.S. Census Bureau, 2014, Geography-TIGER/Line ${ }^{\circledR}$ shapefiles and TIGER/Line files: U.S. Census Bureau data base, accessed April 27, 2015 at 2014 McHenry County, Illinois, Lines were converted to a $30-\mathrm{m}$ grid that matches the NLCD 2011 dataset, NLCD 2014, accessed April 27, 2015, at https://www.census.gov/geo/maps-data/data/tigerline.html.

U.S. Census Bureau, 2015, McHenry County, IllinoisHistorical data 1980 and 2010: U.S. Census Bureau data, accessed August 2014 at http:/quickfacts.census.gov/qfd/ states/17/17111.html.

U.S. Environmental Protection Agency, 1986, Quality criteria for water 1986: U.S. Environmental Protection Agency, Office of Water Regulations and Standards, EPA 440/5-86-001, 477 p. 
U.S. Environmental Protection Agency, 1988, Ambient water quality criteria for chloride-1988: U.S. Environmental Protection Agency, Office of Water Regulations and Standards, EPA 440/5-88-001, 47 p., accessed May 14, 2015, at http://www.epa.gov/ost/pc/ambientwqc/ chloride1988.pdf.

U.S. Environmental Protection Agency, 1992, Secondary drinking water regulations - Guidance for nuisance chemicals: U.S. Environmental Protection Agency, EPA 810/K-92-001, accessed May 14, 2015, at http://water.epa. gov/drink/contaminatns/secondarystandards.cfm.

U.S. Environmental Protection Agency, 2007, Technical fact sheet-Final rule for arsenic in drinking water, August 28, 2007: U.S. Environmental Protection Agency, Office of Ground Water and Drinking Water, EPA 815-F-00-016, accessed August 2015 at https://www.epa.gov/sites/ production/files/2014-03/documents/arsenic_factsheet_ cdc_2013.pdf.

U.S. Environmental Protection Agency, 2008, Drinking water health advisory for boron: U.S. Environmental Protection Agency, Health and Ecological Criteria Division, 65 p., accessed July 2016 at https://www.epa.gov/sites/production/ files/2014-09/documents/drinking_water_health_advisory_ for_boron.pdf.

U.S. Environmental Protection Agency, 2011, Trichloroethylene; CASRN 79-01-6-Integrated risk information system chemical assessment summary: U.S. Environmental Protection Agency, National Center for Environmental Assessment, 65 p., accessed July 2015 at https://cfpub.epa.gov/ncea/iris/iris_documents/documents/ subst/0199_summary.pdf.

U.S. Environmental Protection Agency, 2012, 2012 edition of the drinking water standards and health advisories: Washington D.C., U.S. Environmental Protection Agency, Office of Water, EPA 8822-S-12-001, 20 p., accessed June 16, 2015, at https://www.epa.gov/sites/production/ files/2015-09/documents/dwstandards2012.pdf.

U.S. Geological Survey, variously dated, National field manual for the collection of water-quality data: U.S. Geological Survey Techniques of Water-Resources Investigations, book 9, chaps. A1-A10. [Also available at http://pubs.water. usgs.gov/twri9A.]

U.S. Geological Survey, 1999, The quality of our Nation's water-Nutrients and pesticides: U.S. Geological Survey Circular 1225, 82 p., accessed June 15, 2015, at http://pubs. usgs.gov/circ/circ1225/index.html.

U.S. Geological Survey, 2015, Multi-resolution land characteristics consortium-National Land Cover Database: U.S. Geological Survey database accessed August 2015 at http://www.mrlc.gov/.
U.S. Geological Survey, 2016b, Estimated water use for Illinois, 1985 (by county): U.S. Geological Survey data, accessed February 2015, at http://water.usgs.gov/watuse/ data/1985/index.html.

U.S. Geological Survey, 2016c, Estimated water use for Illinois, 2010 (by county): U.S. Geological Survey data, accessed February 2015, at http://water.usgs.gov/watuse/ data/2010/index.html.

U.S. Geological Survey, 2016a, Water use in the United States - County level data for 2010: U.S. Geological Survey data, accessed August 2014 at http://water.usgs.gov/watuse/ data/2010/index.html.

U.S. Geological Survey, 2016d, pH-Water properties-The USGS Water Science School: U.S. Geological Survey website, accessed May, 2015 at http://water.usgs.gov/edu/ ph.html.

U.S. Geological Survey, 2016e, Water properties and measurements: U.S. Geological Survey website, accessed May, 2015, at https://water.usgs.gov/edu/characteristics. html.

U.S. Geological Survey, 2017, National Water Information System-Web Interface - USGS Water Data for the Nation: U.S. Geological Survey database, https://waterdata.usgs. gov/nwis.

Wagner. R.J., Boulger, R.W., Jr., Oblinger, C.J., and Smith, B.A., 2006, Guidelines and procedures for continuous water-quality monitors-Station operation, record computation, and data reporting: U.S. Geological Survey Techniques and Methods 1-D3, 51 p. plus 8 attachments.

Walton, W.C., 1965, Ground-water recharge and runoff in Illinois: Illinois State Water Survey Report of Investigation, $48 \mathrm{p}$.

Willman, H.B., 1971, Summary of the geology of the Chicago area: Illinois State Geological Survey Circular 460, p. 77

Woller, D.M., and Sanderson, E.W., 1976, Public groundwater supplies in McHenry County, Illinois: Urbana, Illinois State Water Survey Bulletin 60-19, 52 p.

Zaugg, S.D., Sandstrom, M.W., Smith, S.G., and Fehlberg, K.M., 1995, Methods of analysis by the U.S. Geological Survey National Water-Quality LaboratoryDetermination of pesticides in water by $\mathrm{C}-18$ solid-phase extraction and capillary-column gas chromatography/mass spectrometry with selected-ion monitoring: U.S. Geological Survey Open-File Report 95-181, 60 p.

Zogorski, J.S., Carter, J.M., Ivahnenko, Tamara, Lapham, W.W., Moran, M.J., Rowe, B.L., Squillace, P.J., and Toccalino, P.L., 2006, The quality of our Nation's watersVolatile organic compounds in the Nation's ground water and drinking-water supply wells: U.S. Geological Survey Circular 1292, $101 \mathrm{p}$. 



\section{Appendix A. Well Log Lithology of National Water-Quality Assessment (NAWOA) Monitoring Well 44N9E-20.7c}

Table A1. Well log lithology details for the National Water-Quality Assessment (NAWQA) monitoring well 44N9E-20.7c equipped with a pressure transducer collecting continuous 15-minute water-level data.

\begin{tabular}{ccclc}
\hline Monitoring well & Station no. & $\begin{array}{c}\text { Well depth } \\
\text { (feet) }\end{array}$ & Lithology & $\begin{array}{c}\text { Thickness } \\
\text { (feet) }\end{array}$ \\
\hline 44 N9E-20.7c & 421533088421801 & 25 & Clayey sand & 3 \\
& & & Clay & 2 \\
& & & Sandy clay & 2 \\
& & & Clay & 4 \\
& & & Clayey sand & $13+$ \\
\hline
\end{tabular}



Publishing support provided by the U.S. Geological Survey

Science Publishing Network, Tacoma Publishing Service Center

For more information concerning the research in this report, contact the Director, Illinois Water Science Center

U.S. Geological Survey

$405 \mathrm{~N}$ Goodwin

Urbana, IL 61801

https://il.water.usgs.gov 
